\title{
DISTINÇÃO E REVOGAÇÃO DE PRECEDENTES NO DIREITO BRASILEIRO
}

\author{
Tese de doutorado apresentada à banca \\ examinadora da Faculdade de Direito da \\ Universidade de São Paulo, como exigência para \\ obtenção do título de doutor em Direito, sob \\ orientação do Professor Associado Rodolfo de \\ Camargo Mancuso
}




\section{AGRADECIMENTOS}

A Deus e aos meus pais, pela vida e pelas oportunidades.

A Gerliana, porque o amor que sinto por ela é incondicional e imenso e porque ela me faz muito feliz, e qualquer coisa que eu escrevesse diferente disso seria pouco.

A Julia, um amor sem precedentes, para quem eu dedico não só este trabalho mas toda a minha vida.

Ao Professor Rodolfo de Camargo Mancuso, que não me conhecia, aceitou-me como orientando no mestrado e no doutorado e fez com que eu pudesse aprender com seu conhecimento jurídico, conviver com sua invejável figura humana, perceber a sua retidão de caráter e orgulhar-me muito de tudo isso. 


\section{DISTINÇÃO E REVOGAÇÃO DE PRECEDENTES NO DIREITO BRASILEIRO}

Tese de doutorado apresentada à banca examinadora da Faculdade de Direito da Universidade de São Paulo, como exigência para obtenção do título de doutor em Direito, sob orientação do Professor Associado Rodolfo de Camargo Mancuso

Data da aprovação:

Nome:

Título:

Instituição:

Nome:

Título:

Instituição:

Nome:

Título:

Instituição:

Nome:

Título:

Instituição:

Nome:

Título:

Instituição: 


\section{RESUMO}

A tese busca demonstrar que o Brasil mudou de um modelo processual em que os precedentes tinham no máximo efeitos persuasivos para um modelo no qual eles podem decidir sumariamente os destinos de uma demanda. Por ser um país originalmente filiado ao sistema jurídico da civil law, no qual as regras são provenientes principalmente de leis e atos normativos, essa incorporação de precedentes não foi feita de modo natural, o que trouxe como consequência algumas particularidades que podem gerar contradições e perplexidades. No trabalho foram apresentadas as vantagens e desvantagens da opção por um modelo baseado em precedentes judiciais, expondo-se que os pontos positivos superam os negativos. Em seguida, depois de terem sido expostos alguns conceitos básicos a respeito da teoria do precedente judicial, necessários para a compreensão das conclusões seguintes, estudou-se quais foram as alterações feitas na legislação brasileira para incorporar influências do sistema jurídico da common law, demonstrando-se o impacto delas na técnica processual civil. Por fim, foram analisados os institutos da distinção (distinguishing) e da revogação (overruling) de precedentes, com vistas a demonstrar que sua correta aplicação serve para corrigir eventuais excessos ou desvios que podem ocorrer quando se opta por uma técnica de resolução de conflitos com base em precedentes. A tese adotou uma perspectiva favorável à aplicação dessa técnica de julgamento como instrumento de solução rápida e justa de processos judiciais, desde que o modelo precedentalista seja adotado de maneira mais assumida e concreta, o que demanda a aceitação mais expressa de vários de seus institutos. A permanência do modelo brasileiro a meio caminho entre dois sistemas jurídicos não é a melhor, porque a encampação apenas parcial dos institutos ligados a um modelo fundado em precedentes não permite que as vantagens dele decorrentes aconteçam efetivamente.

PALAVRAS-CHAVE:

PRECEDENTE. VINCULAÇÃO. MODELO BRASILEIRO. PROCESSO CIVIL. 


\begin{abstract}
The thesis aims to demonstrate that Brazil has changed from a procedural model in which precedents had at most a persuasive effect to a model in which they can summarily decide the result of a case. Being a country originally affiliated with the legal system of civil law, in which rules mainly come from laws and normative acts, the incorporation of precedent was not natural, which consequently brought some peculiarities that can generate contradictions and perplexities. At this work the advantages and disadvantages of choosing a model based on judicial precedents were presented, being exposed that the positives outweigh the negatives. Then, after exposing some basic concepts about the theory of judicial precedent, necessary for understanding the conclusions which follows, changes in Brazilian laws to incorporate the influences of common law legal system were studied, demonstrating their impact on civil procedural technique. Finally, the institutes of distinguishing and overruling of precedents were analyzed, in order to demonstrate that its correct application serves to correct any excesses or deviations that may occur when an option for a conflict resolution technique based on precedents is made. The thesis adopted a perspective in favor to the application of this technique as a way for fast and fair judicial judgements, provided that the model based in precedents is adopted in a more concrete and assumed way, which requires more explicit acceptance of several of its institutes. The permanence of the Brazilian model halfway between two legal systems is not the best, because only partial acceptance of the institutes attached to a model based on precedent does not allow the advantages that comes from it actually to happen.
\end{abstract}

\title{
KEYWORDS:
}

PRECEDENT. BINDING. BRAZILIAN MODEL. CIVIL PROCEDURE. 


\section{ZUSAMMENFASSUNG}

Die gegenwärtige These versucht darzustellen, dass Brasilien von einem Prozess-Modell, wo die Präzendenzfälle höchstens überzeugende Wirkung hatten, auf ein Modell übergewechselt hat, in dem es summarisch die Ergebnisse eines Falls entscheiden kann. Da Brasilien ein ursprünglich mit dem Rechtswesen der civil law verbundenes Land ist, bei welchem die Regeln hauptsächlich von normativen Gesetzen und Amtshandlungen herstammen, wurde diese Einverleibung von Präzedenzfällen nicht auf natürliche Weise vollzogen, was als Folge einige, Widersprüche und Verwirrungen mit sich bringende Besonderheiten hatte. Bei dieser Arbeit wurden die Vor- und Nachteile der Wahl eines auf gerichtliche Präzedenzfälle gründenden Modells aufgeführt, und es wurde dargelegt, dass die Vorzüge die Nachteile übertreffen. Daraufhin, nachdem einige Grundbegriffe zur Theorie des Präzedenzfalls erläutert wurden, die für das Verständnis der folgenden Schlussfolgerungen notwendig sind, wurde untersucht, welche Änderungen innerhalb der brasilianischen Gesetzgebung vorgenommen wurden, mit dem Zweck, die Einflüsse des Rechtssystems der common law einzuverleben, sowie die Auswirkungen derselben auf die Zivilprozesstechnik. Schliesslich wurden die Einrichtungen der Unterscheidung (distinguishing) und der Überstimmung (overruling) von Präzedenzfällen untersucht, um nachzuweisen, dass ihre korrekte Anwendung dazu dient, eventuelle vorkommende Übersteigerungen oder Abweichungen zu korrigieren, wenn man sich für eine Technik von Konfliktlösungen auf Grund von Präzedenzfällen entscheidet. Die These nahm einen Standpunkt an, der die Anwendung dieser Urteilstechnik begünstigt, als ein Instrument der schnellen und gerechten Lösung bei Rechtsprozessen, unter der Voraussetzung, dass das Präzedenz-Modell in einer realistischeren und stellungeinnehmenderen Weise angewandt wird, was eine ausdrücklichere Akzeptierung seiner verschiedenen Instituionen voraussetzt. Die Lage des brasilianischen Modells auf halbem Weg zwischen zwei juristischen Systemen ist nicht die beste, da die nur zum Teil bestehende Anerkennung von Institutionen, die einem auf Präzedenzfällen erbauten Modell verbunden sind, es nicht erlaubt, dass die aus ihm entstandenen Vorzüge effektiv zustandekommen.

\section{SCHÜSSELWÖRTER:}

Präzendenzfall. Verknüpfung. Brasilianisches Modell. Zivilprozess 


\section{SUMÁRIO}

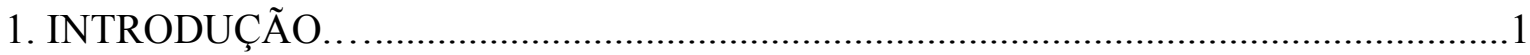

2. PRECEDENTES: ALGUNS ASPECTOS IMPORTANTES …....................................

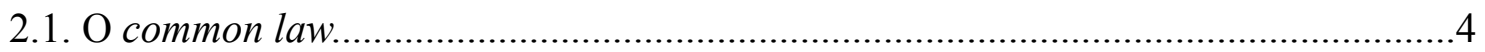

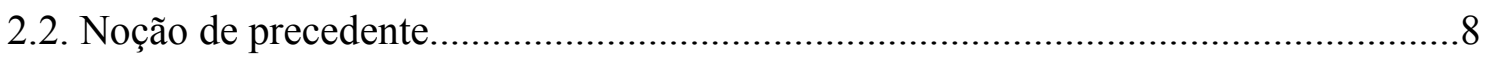

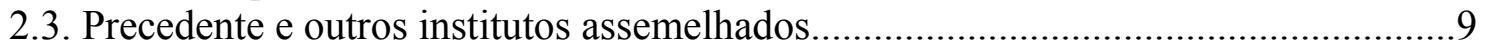

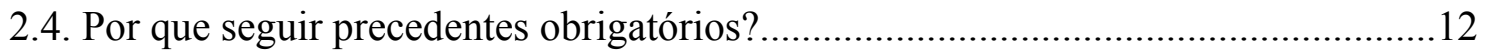

2.6. Os precedentes não violam o princípio da legalidade..............................................29

2.7. Caráter prospectivo da decisão em um sistema precedentalista (o olhar para

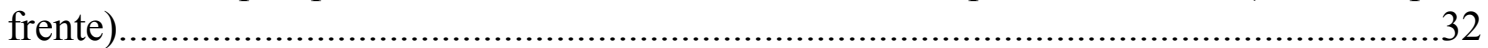

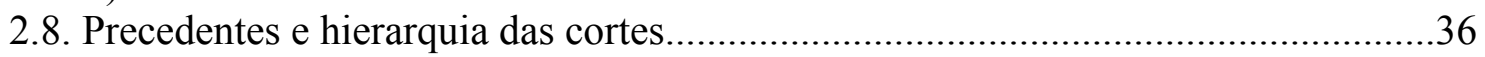

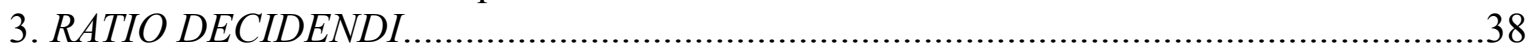

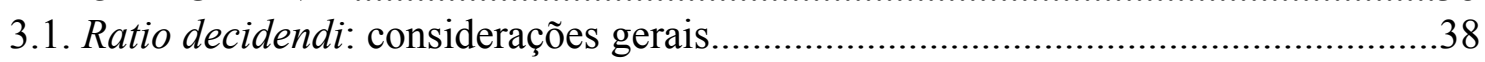

3.2. Métodos de identificação da ratio decidendi do precedente....................................45

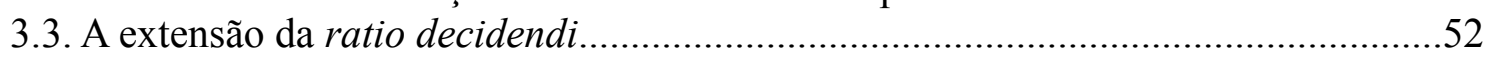

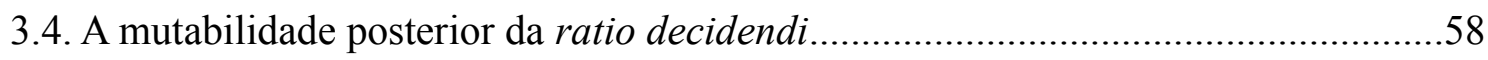

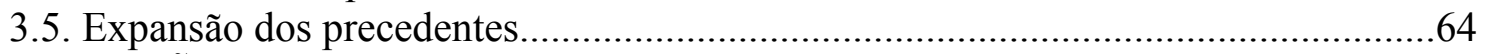

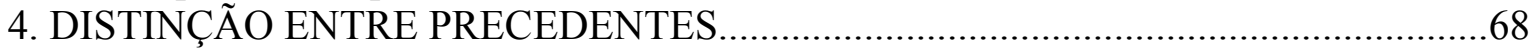

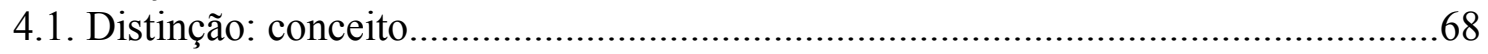

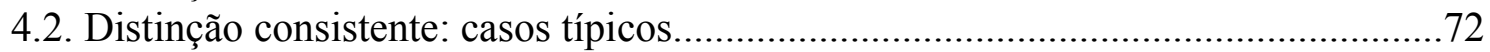

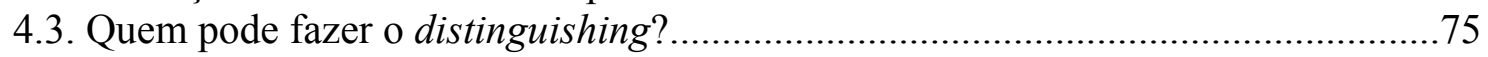

4.4. A questão formal na distinção: a fundamentação..................................................76

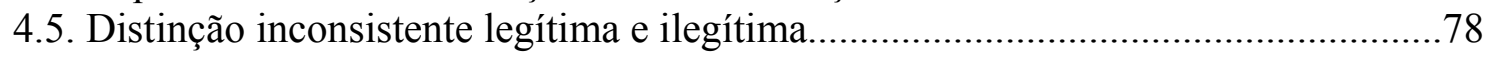

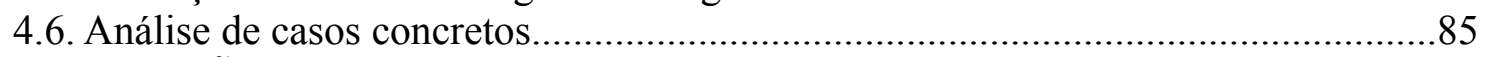

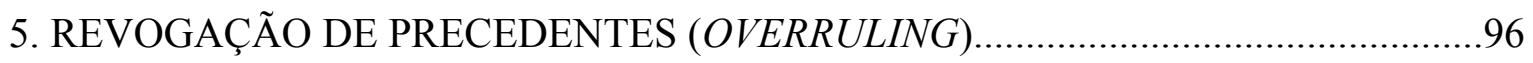

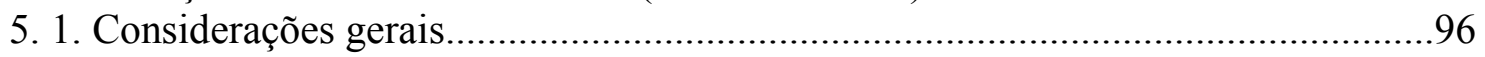

5.2. Revogação de precedentes e distinções inconsistentes legítimas...........................101

5.3. Revogação de precedentes e crítica doutrinária. O papel e a importância da

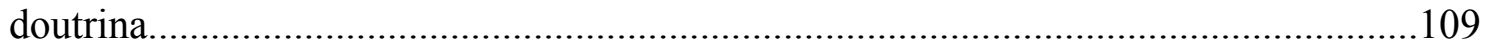

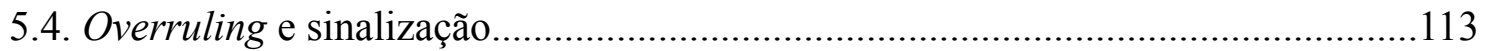

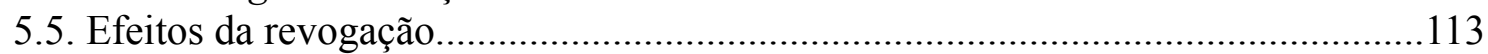

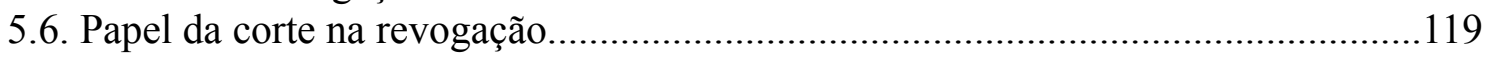

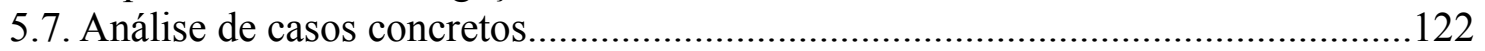

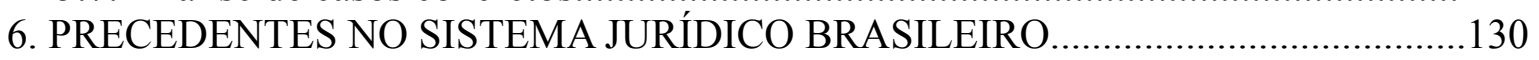

6.1. A constante busca pela uniformização nas decisões............................................130

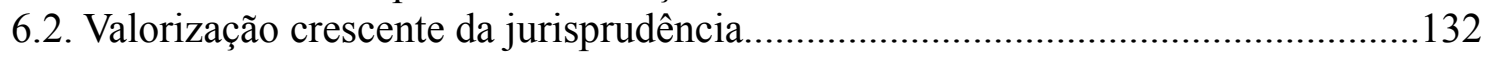

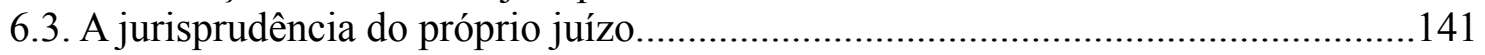

6.4. O surgimento de julgamentos efetivamente vinculantes...................................... 144

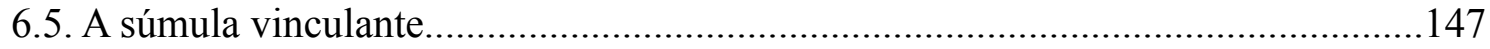

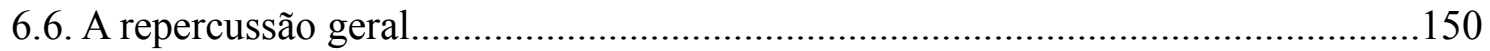

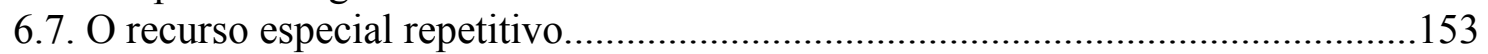

6.8. Controle de constitucionalidade e teoria dos motivos determinantes.......................157

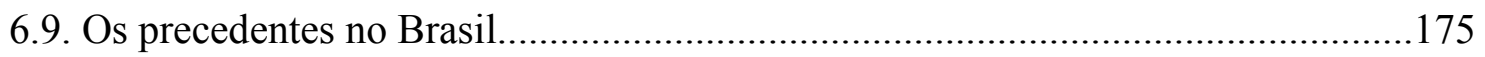

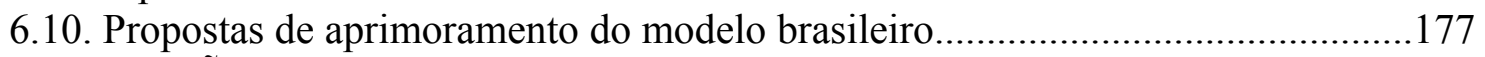

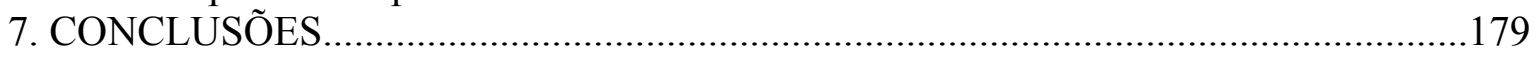

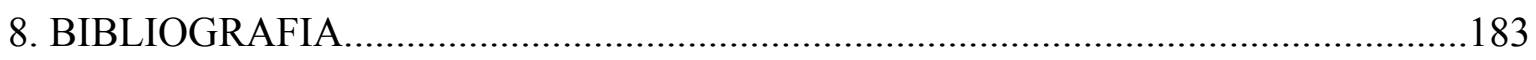


INTRODUÇÃO

Já se tornou lugar comum falar-se que o Poder Judiciário, no Brasil, vivencia uma crise causada pelo elevado número de processos que tem de apreciar em todas as instâncias. A esse respeito, são apresentados números e estatísticas, sob os mais diversos enfoques, ora mostrando que o número de feitos ajuizados em um determinado ano superou o número de processos encerrados, ora acusando a insuficiência do número de juízes relativamente ao número de habitantes, ora criticando os julgadores de uma dada localidade por apresentarem baixa produtividade.

Nesse contexto, várias são as alternativas sugeridas para tentar melhorar o quadro. Dentre elas, pode-se citar como exemplos propostas de incentivar os métodos alternativos de solução de controvérsias, inclusive não jurisdicionais, de coletivizar as demandas individuais de massa, de estabelecer metas a serem cumpridas pelos juízes, de aumentar o número de magistrados e sua estrutura de trabalho ou, ainda, de reduzir o número de recursos como forma de fazer os processos terminarem mais rapidamente. Enfim, são muitas. Todas as sugestões têm seus méritos e seus inconvenientes, e talvez nenhuma delas seja suficiente, por si só, para resolver o problema, que existe e é grave.

Já faz pelo menos duas décadas que as leis processuais têm sido alteradas para utilizar a jurisprudência, sumulada ou não, como meio de resolução mais rápida de conflitos. Esse fato, além de representar mais uma tentativa de solução do problema do excesso de demandas para serem resolvidas pelo Judiciário, representa a encampação de institutos aos quais o sistema processual brasileiro, ligado à civil law, ordinariamente não estava afeito. $\mathrm{O}$ paulatino crescimento em importância da jurisprudência tem trazido para discussão a circunstância de o modelo processual brasileiro estar, gradativamente, espelhando-se em institutos do common law, debatendo-se sobre as consequências boas e ruins que tal pode acarretar. 
A análise da legislação sugere que o legislador tomou gosto pela importação de soluções até então mais típicas dos países ligados ao common law e que provavelmente a caminhada ainda não acabou. A doutrina tem apresentado as vantagens da adoção do modelo e até uma proposta de novo Código de Processo Civil atualmente em estágio de projeto de lei reforça o papel das decisões anteriormente proferidas na resolução dos conflitos atuais.

O objeto desta tese consiste em apresentar mais uma contribuição para a tentativa de melhora do cenário acima descrito. Em que pese seja inegável o prestígio que a jurisprudência e as súmulas ganharam no direito brasileiro, ainda é preciso avançar bastante para que os institutos do common law nos quais o legislador brasileiro está se inspirando para comecem a surtir um efeito mais significativo na redução do número de demandas e na solução mais célere das controvérsias.

Com este propósito, é preciso que se conheça um pouco mais algumas características principais de um modelo processual baseado em verdadeiros precedentes - e não apenas em súmulas ou em jurisprudência - para que se tenha consciência das vantagens e desvantagens do modelo e daquilo em que ele pode efetivamente contribuir na resolução em tempo aceitável das demandas.

$\mathrm{O}$ estudo dos precedentes judiciais permite enfoques variados. Eles podem ser abordados na perspectiva da hermenêutica jurídica, sob o viés constitucional ou com fins de direito comparado ou de história do direito. Neste trabalho, porém, o modelo precedentalista será analisado naquilo que ele pode contribuir para o processo como uma técnica de solução de controvérsias. O enfoque é este e às outras análises será feita menção somente naquilo que for necessário para que a técnica processual seja compreendida.

O método utilizado consistiu na observação doutrinária, na apreciação da legislação atual existente a respeito do assunto e também na análise de casos. Aliás, o estudo do modelo de precedentes não prescinde do exame de precedentes, para que se mostre como anda o estado da arte atualmente no Brasil. Buscou-se ser direto naquilo que 
já foi abordado com proficiência em outros estudos, preferindo-se ir mais diretamente às falhas do modelo precedentalista brasileiro e às inovações que podem auxiliar em seu aperfeiçoamento.

Buscando este rumo, discorreu-se primeiros acerca de alguns conceitos básicos que precisam ser conhecidos como ponto de partida, em seguida sobre a noção de precedente e seu conteúdo vinculante, a ratio decidendi, sobre a distinção (distinguishing) e revogação (overruling) de precedentes, mostrando que esses dois institutos são formas de se garantir mudança e evolução do direito, e, nessa qualidade, devem servir como estímulo a que o processo brasileiro aceite de modo mais assumido, desabrido e sem receios um verdadeiro modelo precedentalista, já que tal modelo tem a cautela de não impedir o avanço do direito, ao mesmo tempo em que assegura diversos valores positivos. Na situação atual, o Brasil se encontra paradoxalmente querendo gozar as vantagens de um modelo baseado em precedentes mas parou a meio caminho e, por isso, não chega propriamente a se beneficiar o tanto que poderia, o que consequentemente finda sendo insuficiente para ajudar na resolução do problema do atravancamento do Poder Judiciário.

A tese, portanto, é entusiasta do modelo precedentalista e busca apresentar propostas para que tal modelo venha efetivamente a servir como uma boa e eficaz técnica processual de solução de controvérsias. 
PRECEDENTES: ALGUNS ASPECTOS IMPORTANTES

2.1. O common law. 2.2. Noção de precedente. 2.3. Precedente e outros institutos assemelhados. 2.3.1. Precedente e súmula. 2.3.2. Precedente e jurisprudência. 2.4. Por que seguir precedentes obrigatórios? 2.4.1. Isonomia processual. 2.4.2. Segurança jurídica (previsibilidade, uniformidade e estabilidade). 2.4.3. Celeridade, racionalidade e eficiência. 2.4.4. Fortalecimento institucional e aumento da credibilidade (redução das chances de decisões conflitantes). 2.4.5. Função social do Poder Judiciário. 2.4.6. A força normativa da Constituição e o reforço do STF como tribunal constitucional. 2.5. Por que não seguir precedentes? 2.6. Os precedentes não violam o princípio da legalidade. 2.7. Caráter prospectivo da decisão em um sistema precedentalista (o olhar para frente). 2.8. Precedentes e hierarquia das cortes.

\subsection{O common law.}

A vinculação dos órgãos judiciários aos precedentes surgiu nos países que adotam o sistema da common law, sendo uma de suas principais características. Este sistema, por sua vez, tem origem na Inglaterra e a partir dela se espraiou para outros países cujo modelo seguiu o do direito inglês. Tal ocorreu notadamente com os países que foram colonizados pela Inglaterra, tais como os Estados Unidos da América, o Canadá e a Austrália. Já o sistema romano-germânico (civil law) tem por base a lei, regra de direito abstrata e geral, editada pelo parlamento, o qual, integrado por representantes do povo, verifica as necessidades da sociedade.

Embora os sistemas da common law e da civil law (sistema romano-germânico) estejam se aproximando cada vez mais, tornando, na prática, menores as diferenças entre eles $^{1}$, ainda é importante mostrar suas principais particularidades e diferenças, até para que fiquem registradas as bases originais de cada qual e se possa perceber quando um instituto

\footnotetext{
${ }^{1}$ Eduardo Cambi fala que a circulação dos modelos jurídicos da civil law e da common law representa consequência inevitável da globalização (Neoconstitucionalismo e neoprocessualismo - direitos fundamentais, políticas públicas e protagonismo judiciário, p. 144).
} 
ou característica típica de um está penetrando ou prevalecendo no outro, fato que, no Brasil, vem ocorrendo de maneira particularmente perceptível no pertinente ao aumento no prestígio dos precedentes judiciais.

O sistema da common law evoluiu com a finalidade de deixar o processo sempre apto para que o juiz pudesse resolver as demandas, ainda que ausentes normas oriundas do parlamento sobre as mais diversas matérias submetidas ao Poder Judiciário. Nesse contexto, o respeito aos precedentes surge na Inglaterra, um país originalmente sem apego à legislação e no qual, talvez por isso, a importância da codificação nunca foi significativa. O common law objetiva solucionar os casos concretos de maneira independente da legislação, preocupando-se principalmente com a segurança jurídica, a isonomia e o pragmatismo. $^{2}$

Surge, assim, o chamado stare decisis, que resumidamente significa que os precedentes judiciais devem ser seguidos. À falta de legislação escrita, no common law o direito escrito vinha dos precedentes e das regras jurídicas que lhes serviram de base e de razão de decidir (a ratio decidendi). A norma que se deve obedecer nos casos futuros não se encontra escrita em um texto normativo tal como conhecido no sistema do civil law (códigos ou leis), mas advém do precedente. Por sua vez, a regra que obriga o respeito e a obediência aos precedentes deriva do próprio sistema da common law, que simultaneamente não era afeito à legislação escrita e não podia ficar sem fonte segura das normas a serem observadas em sociedade. De acordo com Edgard Allan Farnsworth, "a justificação comumente dada a essa doutrina pode ser resumida em quatro palavras: igualdade, previsibilidade, economia e respeito. O primeiro argumento é que a aplicação da mesma regra em casos análogos sucessivos resulta em igualdade de tratamento para todos que se apresentam à justiça. O segundo é que uma sucessão consistente de precedentes contribuiu para tornar previsível a solução de futuros litígios. O terceiro é que o uso de um critério estabelecido para solução de novos casos poupa tempo e energia. O quarto é que a adesão a decisões anteriores mostra o devido respeito à sabedoria e experiência das

\footnotetext{
${ }^{2}$ A esse respeito, Roland Sèroussi é peremptório ao garantir que "o direito inglês é, em essência, um direito jurisprudencial (case law). As regras do direito da Inglaterra e do País de Gales estão sempre em condições de fornecer de imediato a solução de um litígio" (Roland Sèroussi, Introdução ao direito inglês e norteamericano, p. 25).
} 
gerações passadas de juízes". ${ }^{3}$

Por isso é que se diz que o precedente na common law apresenta duas finalidades precípuas. Uma, mais imediata, a de resolver o caso concreto propriamente dito. Outra, a de fixar bases jurídicas para que outros casos possam ser decididos de igual maneira, permitindo a atuação do sistema com previsibilidade, segurança jurídica e isonomia.

Como visto, dois dos principais motivos a justificar o stare decisis, isto é, a observância obrigatória dos precedentes, são a isonomia e a segurança jurídica, na medida em que a resposta judicial aos casos concretos que lhe forem submetidos será a mesma em todas as hipóteses que forem iguais, evitando conflitos entre decisões e trazendo relativa previsibilidade ao sistema, isto é, segurança jurídica.

Entretanto, justamente para consagrar a isonomia, é necessário que as razões de decidir de um dado precedente só venham a ser aplicadas aos outros casos que realmente sejam idênticos, sob pena de se estar aplicando as justificativas dadas para a solução de um caso a outro diverso, violando, em vez de consagrando, o princípio da isonomia. Nos modelos em que a observância dos precedentes é estimulada, a regra segundo a qual a mesma razão autoriza o mesmo direito (ubi eadem est ratio, ibi eadem jus) deve ser rigorosamente cumprida.

Por isso, para que seja seguida essa regra ínsita ao sistema da common law, segundo a qual os precedentes devem ser observados, é preciso que seja verificada a identidade fática e jurídica entre o caso no qual se firmou o precedente e o caso atualmente em julgamento. Por tal motivo é que se afirma que no sistema da common law o julgador se debruça, na verdade, sobre dois casos. $\mathrm{O}$ atual, para lhe verificar as particularidades, e o anterior, no qual foi firmado o precedente, para estudar sua ratio decidendi e analisar se ela se aplica ou não ao caso presente e, em caso afirmativo, em que medida. Note-se que essa

\footnotetext{
${ }^{3}$ Edgard Allan Farnsworth, Introdução ao sistema jurídico dos Estados Unidos, p. 61-62. Para Roland Sèroussi, "os precedentes judiciários (rules of precedent) se impõem pela sua própria existência" (Roland Sèroussi, Introdução ao direito inglês e norte-americano, p. 31). Sobre o stare decisis no direito norteamericano, Osmar Mendes Paixão Côrtes noticia que a “(...) aplicação do stare decisis, da mesma forma que no direito inglês, não foi estabelecida por nenhuma lei, mas, sim, por determinação da Suprema Corte que, aplicando a ideia de que a Corte Superior, que tem poderes para revisar decisões das inferiores, deve ter suas razões observadas, por razões lógicas" (Osmar Mendes Paixão Côrtes, Súmula vinculante e segurança jurídica, p. 132).
} 
conduta de cotejo entre os dois casos se relaciona com a própria finalidade de isonomia, previsibilidade e estabilidade do sistema de obediência aos precedentes, justamente para garantir que casos idênticos serão julgados de igual maneira e para evitar que a casos diferentes seja aplicada a mesma solução jurídica. Para que se deixe de aplicar a ratio decidendi do precedente, é preciso que seja demonstrado pelo julgador a distinção, a diferença, entre o caso atual e o caso anterior no qual surgiu o precedente. Trata-se de proceder ao necessário distinguishing (distinção entre os casos).

Não obstante a cultura do respeito aos precedentes ainda seja a regra nos países adeptos do common law, pode-se afirmar que, a partir de determinada quadra histórica, notadamente a segunda metade do Século XX, começou-se a verificar dois fenômenos que aproximaram um pouco mais o sistema da common law do sistema romano-germânico, ou da civil law. O parlamento passou a editar com maior frequência atos normativos e estes começaram, aos poucos, a ser considerados pelos juízes em suas decisões, as quais deixaram de ter por base única os precedentes. É certo que o statute law, como nesses países usualmente se denomina o direito proveniente das leis, continua carecendo de ser reafirmado pelos tribunais, reafirmação esta que ocorre pela utilização da legislação nas decisões, dando-lhe sentido e alcance, mas é inegável seu gradativamente crescente ganho em importância. Além disso, como um outro fator a aproximar o sistema da common law do sistema da civil law, a própria obediência aos precedentes começou a ser flexibilizada para ser menos rígida, somente se devendo seguir o precedente se ele parecesse correto. Isso porque uma atenção aos precedentes sem maiores reflexões poderia significar injustiça em um dado caso concreto ou mesmo restringir o desenvolvimento do direito.

Particularmente nos Estados Unidos da América, o modelo de observância dos precedentes sempre foi mais amenizado do que na Inglaterra. Primeiramente, por razões históricas, já que vários estados editaram leis revendo entendimentos herdados dos precedentes da Inglaterra, quando esta deixou de ser colonizadora, o que conferiu ao país experiência com o direito proveniente da legislação. Além disso, a existência, desde o início dos tempos de país independente, de uma constituição escrita e de uma suprema corte para aplicá-la, deu aos Estados Unidos da América um modelo no qual são valorizados não só o precedente criado a partir de um caso anterior mas também o 
precedente surgido a partir da interpretação de um texto constitucional, o que, em alguma medida, é parecido com os precedentes surgidos nos países de sistema romano-germânico.

Observa-se, pois, que, com maior ou menor intensidade, aos poucos o sistema da common law vai se permeando de institutos originalmente mais típicos do sistema da civil law, tais como o aumento do relevo do direito legislado e uma obediência menos rigorosa ao modelo de precedentes.

Simultaneamente, tem-se verificado, nos países adeptos do sistema romanogermânico (civil law), o aumento no prestígio atribuído aos precedentes. Aqui, diversamente do que se dá no sistema da common law, o juiz ainda não tem o papel de criar regras gerais a partir de precedentes. A lei é a regra geral e o julgador apenas realiza uma tarefa de interpretação e subsunção, encaixando o caso concreto em uma regra preexistente. Contudo, gradativamente os precedentes foram ganhando espaço e importância, inicialmente como forma de persuasão, sem vincular, e posteriormente com caráter vinculante, de obediência obrigatória, ainda que em casos bem restritos.

No Brasil, país originalmente vinculado ao sistema jurídico romano-germânico (civil law), no qual a fonte primária das normas jurídicas é a lei, a cultura de respeito obrigatório aos precedentes ainda não está suficiente desenvolvida. Segue-se cultuando a lei e até que ela, a lei, diga que o precedente é vinculante, dificilmente a situação mudará, em prejuízo da segurança jurídica, estabilidade, previsibilidade, solução rápida dos litígios e diversas outras vantagens advindas de um modelo precedentalista.

\subsection{Noção de precedente.}

Em um trabalho que se propõe a analisar os precedentes como técnica processual de solução de controvérsias, talvez o primeiro passo a ser dado seja atribuir um conceito a respeito do que se está tratando.

Até por terminologia, precedente é aquilo que vem antes, que antecede. Precedente judicial, portanto, se refere a uma decisão judicial proferida antes do momento 
atual. Especificamente quanto ao objeto deste trabalho, sempre que se falar em precedente estar-se-á se referindo a uma decisão proferida anteriormente a respeito de um dado tema,

com caráter vinculante. É certo que nem tudo no precedente é vinculante e que nem todo precedente é vinculante. Realmente, de toda a decisão precedente só é de cumprimento obrigatório a chamada ratio decidendi, que é uma regra geral, abstrata e vinculante sobre a qual se discorrerá oportunamente (capítulo 3). Mas aqui, na tentativa de facilitar a compreensão, a menção a precedente significará a parte da decisão de cumprimento obrigatório pelos demais julgadores de hierarquia inferior.

A noção de vinculação não é ínsita ao precedente. É algo que a ele se agrega em momento posterior, quando se tem a compreensão de que cumpri-lo obrigatoriamente é a medida mais correta, por alguma razão. Por isso é que existem precedentes que não são vinculantes, sendo apenas persuasivos. Para os fins deste texto, sempre que se estiver a cuidar dos precedentes meramente persuasivos isso deverá ficar claro. Quando tal não for afirmado, o precedente a que se vai estar fazendo menção é o precedente vinculante.

Dessa forma, e em síntese, precedente é a decisão judicial que deve ser obrigatoriamente observada pelos julgadores de hierarquia inferior quando se depararem com casos semelhantes.

\subsection{Precedente e outros institutos assemelhados.}

\subsubsection{Precedente e súmula.}

A súmula é um instituto bem próprio do Brasil. Nasceu a partir do Ministro do STF Victor Nunes Leal. Ele percebeu as dificuldades daquela corte na retenção da memória dos temas que já tinham sido por ela enfrentados e que na grande maioria das vezes não carecia ser apreciado em profundidade novamente. Até então, o que acontecia era que os ministros mais antigos apenas diziam oralmente para os mais recentemente chegados qual era a posição da corte a respeito de dado tema. O Ministro Victor Nunes Leal, então, começou a fazer anotações abrangendo o conteúdo do que a corte tinha decidido, os ministros que proferiram votos vencedores e vencidos e quando a decisão 
tinha sido proferida. Surgia, aí, um embrião de sistematização.

Por influência do Ministro Victor Nunes Leal, em 1963 foi incluída no regimento interno do tribunal a menção aos enunciados da súmula do STF, dando-lhes previsão normativa e atribuindo-lhes efeitos processuais. Em sua origem, o termo "súmula" significava o conjunto dos "enunciados", os quais eram numerados e cada um dizia respeito a um dado tema específico. Foi só posteriormente, em decorrência da praxe, que o vocábulo "súmula" passou a significar também cada um dos antigos enunciados. ${ }^{5}$

Súmula, pois, é um enunciado que sintetiza, por meio de uma formulação resumida, qual é o entendimento da corte a respeito de determinado assunto. Assim, por exemplo, por apresentar diversos julgados entendendo que a decisão proferida em processamento de precatórios tem natureza administrativa e não jurisdicional e, por isso, não comporta recurso extraordinário, que é instrumento tipicamente jurisdicional, o STF editou a Súmula 733, segundo a qual "não cabe recurso extraordinário contra decisão proferida no processamento de precatórios". Tem-se, como se vê, um resumo do que é o posicionamento do tribunal acerca de dado tema.

Portanto, a súmula, ainda quando vinculante, não pode ser confundida com o precedente. Ela é apenas o resumo do entendimento da corte em vários casos, enquanto que um precedente pode advir do julgamento de um caso apenas. Um outro diferenciador está em que a menção a precedente é associada a existência de uma regra geral nele existente e aplicável a outros casos similares. A súmula é apenas descritiva de um fato, o de haver no tribunal entendimento jurisprudencial consolidado sobre determinada questão, ou seja, não contempla conteúdo normativo de rigorosamente nenhum tipo. ${ }^{6}$ Além disso, como a regra geral e abstrata advinda do precedente não é expressa sob uma formulação, sendo na verdade apreendida a partir de determinados elementos contidos no caso e na decisão, os

\footnotetext{
${ }^{4}$ Derivado do latim summula, que significa reunião, compêndio.

5 Informações retiradas da obra coordenada por Fernando Dias Menezes de Almeida (Memória jurisprudencial: Ministro Victor Nunes, p. 31-33). O art. 102 do Regimento Interno do Supremo Tribunal Federal segue fazendo referência aos enunciados e aos verbetes da "Súmula do Supremo Tribunal Federal".

${ }^{6}$ Neste sentido, Fernando Dias Menezes de Almeida (Memória jurisprudencial: Ministro Victor Nunes, p. 34). "A súmula é pura declaração solene do tribunal de que considera determinada questão pacificada e, consequentemente, dispensa novas discussões, citações de precedentes, longas e eruditas fundamentações" (considerações do Ministro Sepúlveda Pertence no julgamento, pelo STF, do HC 85185/SP, Rel. Min. Cezar Peluso, unânime, j. em 10/8/2005, pub. DJ 1\%/9/2006, p. 18).
} 
julgadores dos casos seguintes têm alguma maleabilidade e flexibilidade para definir, sem burlas, o alcance e a extensão da ratio decidendi do precedente, ou seja, há um contributo do juiz do caso posterior para o alcance do precedente, o que não acontece no caso da súmula, que já é pronta e entregue pela própria corte que a edita, sem nenhuma participação por parte de quem vai aplicá-la.

\subsubsection{Precedente e jurisprudência.}

“(...) a jurisprudência é a forma concordante em que os órgãos judiciários se pronunciam para resolver casos similares. É o conjunto de decisões, atinentes ao mesmo problema jurídico, que termina por fixar critérios ou regras gerais que justificam o caráter objetivo da jurisprudência como fonte do direito. Em outros termos, são as decisões concordantes que criam critérios objetivos de julgamento" (Eduardo Cambi, Neoconstitucionalismo e neoprocessualismo - direitos fundamentais, políticas públicas e protagonismo judiciário, p. 149 - destaques existentes no original).

Por se tratar de um "conjunto de decisões em um mesmo sentido", isto é, vários julgados dando à questão jurídica a mesma solução, a jurisprudência adquiriu um caráter mais quantitativo do que qualitativo. Na praxe forense, é muito comum se encontrar em petições e decisões a transcrição de várias e longas ementas de acórdãos, apresentando-as como se elas se bastassem por si, sem necessidade de explorar o que elas efetivamente decidiram, em que contexto decidiram e qual a relação delas com o caso atual sob julgamento. ${ }^{7}$ Aqui reside uma diferença bem significativa relativamente ao precedente. Este, para que vincule, basta que seja semelhante ao caso posterior. É preciso que o julgador demonstre a similitude e o amoldamento do segundo caso ao precedente. Desde que isso seja feito e a semelhança encontrada, o precedente é aplicado, independentemente de ele ter já sido reiterado em diversos casos ou de ter sido proferido uma única vez. $\mathrm{O}$ fator quantidade não é necessário para fins de considerá-lo como de cumprimento obrigatório.

\footnotetext{
${ }^{7}$ Eduardo Cambi afirma que condutas processuais deste tipo contribuem para o que chama de "caos da jurisprudência", que mistura situações diferentes, sem critérios racionais, gerando instabilidade e insegurança jurídicas (Neoconstitucionalismo e neoprocessualismo - direitos fundamentais, políticas públicas e protagonismo judiciário, p. 155).
} 


\subsection{Por que seguir precedentes obrigatórios?}

\subsubsection{Isonomia processual}

A doutrina não é uniforme ao conceituar o que seja um princípio. Há diversas correntes doutrinárias a respeito, cada uma buscando encontrar uma característica que sirva para diferenciar os princípios das demais categorias jurídicas. Essa divergência, em alguma medida, é boa, porque no mínimo demonstrar que os princípios adquiriram uma relevância científica tal que a doutrina tem se dedicado a eles com freqüência e profundidade. José Joaquim Gomes Canotilho conseguiu resumir os principais pontos da controvérsia:

“(...) (1) as regras e princípios são duas espécies de normas; (2) a distinção entre regras e princípios é uma distinção entre espécies de normas. Saber como distinguir, no âmbito do superconceito norma, entre regras e princípios, é uma tarefa particularmente complexa. Vários são os critérios sugeridos. A) Grau de abstração: os princípios são normas com um grau de abstração relativamente elevado; de modo diverso, as regras possuem uma abstração relativamente reduzida. $B$ ) Grau de determinabilidade na aplicação do caso concreto: os princípios, por serem vagos e indeterminados, carecem de mediações concretizadoras (do legislador, do juiz), enquanto as regras são suscetíveis de aplicação direta. C) Carácter de fundamentalidade no sistema das fontes de direito: os princípios são normas de natureza estruturante ou com um papel fundamental no ordenamento jurídico devido à sua posição hierárquica no sistema das fontes (ex.: princípios constitucionais) ou à sua posição estruturante dentro do sistema jurídico (ex.: princípio do Estado de Direito). D) Proximidade da idéia de direito: os princípios são 'standards' juridicamente vinculantes radicados nas exigências de 'justiça' (Dworkin) ou na 'idéia de direito' (Larenz); as regras podem ser normas vinculantes com um conteúdo meramente funcional. E) Natureza normogenética: os princípios são fundamentos das regras, isto é, são normas que estão na base ou constituem a ratio de regras jurídicas, desempenhando, por isso, uma função normogenética fundamentante.

Como se pode ver, a distinção entre princípios e regras é particularmente complexa. Essa complexidade deriva, muitas vezes, do facto de não se esclarecerem duas questões fundamentais: (1) saber qual a função dos princípios, ou seja, se têm uma função retórica-argumentativa ou são normas de conduta; (2) saber se entre princípios e regras existe um 
denominador comum, pertencendo à mesma 'família' e havendo apenas uma diferença de grau (quanto à generalidade, conteúdo informativo, hierarquia das fontes, explicitação do conteúdo, conteúdo valorativo) ou se, pelo contrário, os princípios e as regras são suscetíveis de uma diferenciação qualitativa". ${ }^{8}$

Não é o propósito desse estudo descer a minúcias a respeito das razões pelas quais esta ou aquela teoria dos princípios é mais ou menos merecedora de elogios ou críticas. No entanto, em um trabalho a respeito de um princípio, ao menos uma tomada de posição tem de existir, para que se saiba do que se está tratando.

Com essa finalidade, uma suficiente definição de princípio é a de Carlos Ari Sundfeld, para quem os princípios “(...) são as ideias centrais de um sistema, ao qual dão sentido lógico, harmonioso, racional, permitindo a compreensão de seu modo de organizarse". ${ }^{9}$ Tal conceito dá o devido realce aos princípios e deixa claro que eles são obrigatórios, na medida em que não se conceberia algo ser central e não se de observância cogente. É o que basta, por ora.

A respeito, agora, precisamente do princípio da isonomia, sua base constitucional está tanto no art. $5^{\circ}$, caput quanto em seu inc. I, da Constituição do Brasil de 1988, os quais, chegando mesmo a uma aparente redundância, estabelecem que "todos são iguais perante a lei, sem distinção de qualquer natureza" e que "homens e mulheres são iguais em direitos e obrigações". Extrai-se daí um compromisso constitucional inequívoco com a igualdade entre todos. Fala-se em igualdade na lei, vale dizer, a lei deve ser aplicada de maneira uniforme para todos e em igualdade diante da lei, a saber, a própria lei não pode conter distinções indevidas.

Especificamente no que diz respeito ao processo civil também houve assunção explícita do ideal de igualdade, por meio do art. 125, I, do Código de Processo Civil (CPC), o qual estabelece que o juiz assegurará às partes igualdade de tratamento.

A igualdade assegurada pela Constituição é a chamada igualdade dinâmica, ou

${ }^{8}$ Direito Constitucional, p. 1160 e 1161.

${ }^{9}$ Fundamentos de Direito Público, p. 133. 
material. Não é que todos tenham de ser, sempre, tratados integralmente de modo igual. O que lei proíbe é (1) o tratamento diferente de situações iguais e (2) o tratamento igual de situações diferentes, ou seja, desequiparações e tratamentos diferenciados são sim possíveis (na verdade, são mesmo necessários), desde que exista uma razão plausível para isso.

No processo civil, classicamente, sempre se discutiu o princípio da igualdade em temas como (1) o prazo diferenciado para a prática de determinados atos estabelecido para alguns sujeitos processuais (art. 188 do CPC), (2) à imprescindibilidade da defensoria pública, para que os hipossuficientes financeiros possam ter acesso à justiça, (3) a possibilidade de se estipular valores menores a título de honorários advocatícios se o sucumbente for determinadas pessoas ( $\S 3^{\circ}$ do art. 20 do CPC) e (4) a existência de remessa necessária (art. 475 do CPC) e de suspensão de execução de liminar somente em favor de pessoas específicas. E, de fato, é inteiramente cabível a discussão sobre se tais previsões agridem ou não o princípio da isonomia.

Contudo, essas questões, apesar de relevantes, ficam adstritas à questão do tratamento igualitário das partes dentro de um mesmo processo. O próprio inciso I do art. 125 do $\mathrm{CPC}$ diz que o juiz dirigirá o processo assegurando às partes (do processo, dentro do processo) igualdade de tratamento. Muito pouco se diz sobre o tratamento igualitário das partes em todos os processos. Em obediência ao princípio da isonomia, o Poder Executivo não pode tratar nenhum administrado de maneira diferente, se suas situações foram fática e juridicamente as mesmas. De igual maneira, o legislador também não pode desequiparar o que é essencialmente igual. Já o Poder Judiciário permite que uma mesma e idêntica hipótese concreta seja decidida de maneira distinta, apenas porque dado caso foi julgado por um julgador e não por outro, ou por uma turma do tribunal e não por outra, dentre outras possibilidades e acasos. Ora, se o princípio constitucional da igualdade se destina ao Estado de um modo geral, aí incluídos os três Poderes, o Poder Judiciário não pode deixar de tratar de modo idêntico todas as hipóteses concretas que assim o forem e também não pode tratar igualmente aquilo que é substancialmente distinto.

Com isso, chega-se à conclusão de que para que o princípio da isonomia seja 
efetivamente cumprido também no Poder Judiciário é preciso que exista igualdade não só dentro dos processos mas também em igualdade nas decisões judiciais em todos os processos. Registre-se que a decisão judicial é, em última análise e sob uma perspectiva sistêmica, uma decisão do Poder Judiciário, seja quem for o juiz que a exteriorize. Por isso, o Judiciário, concebido como um todo, não pode, por meio de decisões díspares para casos idênticos, tratar desigualmente quem é igual. Também não pode, sob pena também de violação da igualdade, dar tratamento idêntico a casos distintos.

Em um modelo de observância dos precedentes tem-se que estão em seus referenciais teóricos não só o julgador do caso posterior mas também o juiz do caso concreto em que um dado precedente eventualmente foi estabelecido. O primeiro, porque tem o dever de observar o precedente quando verificar que tem diante de si para julgamento um caso semelhante a outro anteriormente já apreciado. É a perspectiva retrospectiva dos precedentes (olhar para trás). O segundo, porque tem a obrigação de, ao estabelecer um precedente, ter consciência de que o está fazendo e saber as consequências disso, devendo estar atento para a particularidade de que está a criar não apenas uma regra concreta para o caso específico, mas também uma regra geral e abstrata que adiante será repetida em outros casos. É a perspectiva prospectiva dos precedentes (olhar para frente).

Uma questão interessante é perscrutar as razões pelas quais um sistema constitucional/processual optaria por um modelo assim, que de certo modo reduz a liberdade de cada juiz de decidir os casos do modo que quiserem e que, a partir de casos concretos, fixa regras gerais para casos futuros sem que exista a certeza de que essa regra geral será mesmo a melhor para todos os casos.

Um primeiro argumento é a igualdade. Tratar igualmente casos semelhantes. De fato, contraria o senso comum permitir, sob um mesmo regime jurídico, que dois casos semelhantes não recebam tratamento semelhante, ainda que um tenha sido julgado em um determinado lugar, por um determinado juiz e em um dado tempo, enquanto o outro tenha sido apreciado posteriormente, por um julgador diverso, em um lugar diferente. Ora, se esses dois casos tivessem sido julgados em conjunto, ao mesmo tempo e pelo mesmo órgão jurisdicional, dificilmente se teria soluções distintas. Se é assim, a tão só circunstância de 
um julgamento ter sido posterior ao outro, ou seja, eles não terem acontecido simultaneamente, não deve ser bastante justificar, ao menos não isoladamente, que o resultado seja diverso. Se os casos são realmente semelhantes, deve haver igualdade quer sejam eles apreciados simultaneamente, quer seus julgamentos aconteçam em momentos temporalmente distintos.

A grande questão é saber quando dois casos são realmente semelhantes. Um carro, um navio e um avião podem todos ser classificados como veículos, embora sejam, cada um deles, totalmente diferentes uns dos outros, a começar pelo meio em que trafegam. A depender da maior ou menor semelhança que se queira dar, os três tipos de veículos podem ser agrupados (por exemplo, em uma decisão que cuide da necessidade de todos os veículos existentes no país serem obrigados a ter uma identificação e um responsável) ou separados (a uma empresa fabricante de aviões pode vir a ser judicialmente negado um incentivo tributário concedido apenas às empresas fabricantes de carros, por exemplo, a depender do fundamento dado para tal incentivo).

O fato é que quanto mais se particulariza as categorias de semelhança, ou seja, quanto mais detalhes se exige do segundo caso para que seja ele tido por semelhante ao primeiro, mais difícil será o enquadramento do julgado posterior no julgado anterior e menos vinculação terá o precedente, porque sua abrangência será menor. $O$ inverso também é verdadeiro. Quanto menos se exige em detalhes do segundo caso para que seja tido por semelhante ao primeiro, mais vinculação se terá, porque mais fácil será a subsunção do caso seguinte à regra geral estabelecida no julgado anterior. O problema, portanto, é definir o grau de detalhismo ou de abrangência que se quer. O estudo das formas de identificação da ratio decidendi ajudará nesta compreensão.

Um aspecto que deve sempre ser considerado é a ligação existente da isonomia no tratamento dos casos com o reforço na percepção de imparcialidade do Poder Judiciário. $\mathrm{Na}$ medida em que casos assemelhados recebem sempre o mesmo tratamento jurídico, inevitavelmente as partes de cada um destes casos e a sociedade em geral constata que, não importa quem seja, o tratamento é o mesmo. Essa constatação termina por se refletir no incremento da própria credibilidade e respeitabilidade do sistema jurisdicional como um 
todo.

2.4.2. Segurança jurídica (previsibilidade, uniformidade e estabilidade).

Ricardo de Barros Leonel lembra que o "(...) que se busca com a jurisdição e com o processo é o escopo político (estabilidade das instituições estatais e exercício da cidadania), do escopo jurídico (aplicação do direito) e do escopo social (pacificação e educação para se evitar novos conflitos)". Adiante, acrescenta que é preciso que isso aconteça com segurança e previsibilidade. ${ }^{10}$

Se em um dado sistema jurídico se segue o modelo precedentalista, aumenta-se a previsibilidade dos cidadãos, que podem pautar suas condutas a partir de entendimentos jurídicos jurisprudencialmente consagrados, das partes, as quais sabem o que esperar dos litígios judiciais em que ingressam, dos profissionais da área jurídica, que podem aconselhar as partes tanto em sua atividade litigiosa quanto também na consultiva. Trata-se de uma certa capacidade de prever, com razoável extensão de segurança, o que acontecerá no futuro.

Ao falar da agenda para um Judiciário renovado, eficiente e prestigiado socialmente, Rodolfo de Camargo Mancuso elenca seis atributos que reputa serem necessários para que se tenha uma resposta judiciária de qualidade, devendo a prestação jurisdicional ser razoavelmente previsível. $^{11}$ Ora, em um modelo de precedentes, a previsibilidade é razoável, porque as pessoas e os profissionais jurídicos sabem que, para dados fatos, terão dada resposta judicial. E, conforme afirmado por Cândido Rangel Dinamarco, "toda ordem jurídica tem a missão e responsabilidade de definir situações e gerar clima de confiança e tranquilidade das pessoas e grupos quanto a seus direitos,

\footnotetext{
${ }^{10}$ Reclamação constitucional, p. 56.

${ }^{11}$ Acesso à justiça - condicionantes legítimas e ilegítimas, p. 384. Eduardo Cambi também realça a importância da previsibilidade. Segundo ele: "A previsibilidade é marca insuprimível do Estado de Direito. A segurança jurídica serve para proteger a liberdade e promover o desenvolvimento econômico. A variação desmensurada dos critérios de interpretação coloca em risco a liberdade individual, a estabilidade dos contratos e as transações econômicas, porque as pessoas não podem ser programadas automaticamente, de acordo com cambiantes decisões judiciais, como se fossem relógios de pulso sujeitos ao novo horário de verão. Tal estabilidade também serve de critério de controle da atividade judicial, uma vez que o respeito aos precedentes exige uma justificação mínima e razoável, evitando decisões arbitrárias e em total falta de sintonia com julgados pretéritos" (Neoconstitucionalismo e neoprocessualismo - direitos fundamentais, políticas públicas e protagonismo judiciário, p. 162 - destaques existentes no original)
} 
deveres e obrigações, seja para exercê-los e cumpri-los adequadamente, seja para poderem prever consequências do descumprimento próprio ou alheio. Tal é o valor da segurança jurídica, indispensável ao convívio social harmonioso e civilizado". ${ }^{12}$

A segurança jurídica abrange também a uniformidade, isto é, a garantia de que as leis serão aplicadas de maneira uniforme para todos e em todos os lugares, e a estabilidade, ou seja, o direito não deve ser cambiante a toda hora e por qualquer motivo. A uniformidade e a estabilidade evitam surpresas, sobressaltos, diferenciações indevidas ou intempestivas. E não significam que o direito para atendê-las precisa estagnar. Existem mecanismos próprios que permitem a evolução do direito sem agressão à segurança jurídica (capítulos 4 e 5).

\subsubsection{Celeridade, racionalidade e eficiência.}

Não há nenhuma novidade em afirmar que no Brasil hoje se tem uma sociedade de massa, característica da qual decorre uma acentuada conflituosidade em todos os níveis. Problemas, dos mais singelos aos mais complexos, terminam no Poder Judiciário. Além disso, vive-se no Brasil um movimento de um amplo acesso à justiça cada vez mais facilitado, quer subjetivamente, quer objetivamente. No âmbito subjetivo, com a defensoria pública se buscou permitir que mesmo pessoas financeiramente hipossuficientes pudessem postular seus direitos em juízo, o que representa a possibilidade de ingresso em juízo de uma significativa quantidade de pessoas tendo em vista as condições econômicas de boa parte da população brasileira. Na perspectiva objetiva, quase não há mais espécies de direitos que não sejam tuteláveis judicialmente. Os juizados especiais permitem que mesmo as causas de pequena valor financeiro sejam postuladas sem maiores desestímulos nem dificuldades. $\mathrm{O}$ advento das ações coletivas, o aumento no número de legitimados a propô-las e o incremento nas atribuições do Ministério Público permitem que os direitos transindividuais sejam amplamente reivindicáveis em juízo, inclusive questões ligadas ao controle de políticas públicas. Na Justiça Eleitoral cada vez mais se vislumbram discussões a respeito da legitimidade e validade dos pleitos, dos candidatos e dos eleitos, em causas que terminam por tocar em discussões a respeito do próprio regime democrático. Tudo é judicializável. Talvez nunca se tenha levado tão a sério e às últimas consequências a

\footnotetext{
${ }^{12}$ Súmulas vinculantes, p. 237 (destaques existentes no original).
} 
circunstância de caber ao Poder Judiciário proferir "a última palavra" sobre as questões jurídicas.

Em um tal contexto, é compreensível, natural e até esperado que o número de processos judicial aumente em todas as instâncias, com as consequências daí decorrentes, dentre elas a lentidão e a demora. O modelo precedentalista tem ao menos duas contribuições para reduzir os impactos desse contexto de um número imenso de processos a serem apreciados. O primeiro deles decorre da própria previsibilidade e da segurança jurídica, sobre a qual já se discorreu no item 2.4.2 anterior. Ao ter a certeza, ou ao menos conhecer a elevada probabilidade, de que a uma determinada demanda será dada a solução $\mathrm{X}$, a parte que buscaria defender em juízo a solução $\mathrm{Y}$ talvez já nem ingresse com a demanda, ou talvez nem recalcitre em pedido contra si deduzido. A previsibilidade acarreta um fator de desestímulo à litigância por parte daquele contra quem milita a tese fixada no precedente, o que pode levar à própria redução no número de processos.

Além disso, o modelo de precedentes apresenta ainda um outro contributo para um quadro fático de elevado volume de processos, consistente na celeridade e na eficiência. A rigor, nos modelos em que não é necessária a observância de precedentes, cada caso é para ser considerado um caso isolado, diferenciado, e como tal carecendo de ser analisado em profundidade, com todas as suas particularidades. Quando o modelo é de observância obrigatória de precedentes, o julgador do segundo caso apenas tem de demonstrar que a hipótese agora sob julgamento é assemelhada à anterior já decidida e a respeito da qual existe um precedente, não precisando tecer maiores considerações a respeito de questões já enfrentadas e decididas no precedente. Constata-se que a quantidade de temas a serem expressamente enfrentados pelo juiz do caso seguinte é bem mais reduzida, na medida em que basta a ele se reportar ao precedente para justificar o porquê da solução X e não outra. A atividade do juiz, portanto, é bem menor e mais mais facilitada, permitindo com que ele, empregando o mesmo tempo e a mesma estrutura material e humana de trabalho de que disponha, consiga apreciar uma quantidade maior de processos, tornando mais eficiente a gestão do tempo, do pessoal e do material disponíveis e imprimindo aos processos, assim, mais celeridade. 
Já o aumento na eficiência da atividade jurisdicional decorre da redução nas chances de acontecer erro judiciário, porquanto o julgador que segue o precedente apenas repete a solução já dada anteriormente. É claro que sempre vai ser possível a alegação de que o erro estava justamente no precedente, mas para isso o modelo prevê outras soluções, como a distinção ou a revogação, se for o caso. Na perspectiva pura e simples de solução de casos, as possibilidades de erro são bem diminuídas quando apenas se verifica a similitude entre o caso anterior e o posterior e se aplica o precedente.

Em matéria de incremento na racionalidade e na eficiência, talvez a maior contribuição que o modelo precedentalista ofereça à técnica processual de solução de controvérsias seja uma consequência do aumento na celeridade a que se referiu acima. Com a possível redução no número de processos (porque um potencial perdedor na demanda, percebendo que suas chances são diminutas em decorrência de saber que a regra contida no precedente será aplicada em todas as instâncias, sem divergências, talvez sequer ingresse em juízo) e da solução mais rápida que é possível se dar aos processos repetitivos (com a técnica de demonstrar a similitude entre os casos anterior e posterior e depois disso apenas aplicar o precedente, sem necessidade de maiores digressões), sobra mais tempo para decidir as causas inéditas, os leading cases, com a qualidade, a profundidade e a fundamentação que temas novos ainda não enfrentados precisam e merecem. Dessa forma, o tempo ganho com o julgamento mais acelerado - mas feito sem perder legitimidade nem critério - se reverte em prol do próprio sistema judiciário, que passará a contar com decisões melhores nos temas que efetivamente precisam ser decididos, porque ainda não foram, sem desperdício de um tempo tão escasso com questões já enfrentadas e resolvidas.

Ainda na perspectiva do aumento da racionalidade do sistema, a existência de precedentes a respeitos das questões jurídicas podem findar por desestimular demandas sobre temas já decididos, além de estimular acordos, ambas consequências positivas para um quadro de elevado volume processual.

2.4.4. Fortalecimento institucional e aumento da credibilidade (redução das chances de decisões conflitantes). 
Em princípio, todo julgador é livre para decidir a causa de acordo com sua independência funcional e seu livre convencimento, o qual deve ser exposto em decisão fundamentada e pública, para que ela possa ser eventualmente contrastada pela parte prejudicada (arts. 131 e 436 do Código de Processo Civil e art. 93, IX, da Constituição do Brasil de 1988). Dessa forma, cada caso pode ser decidido de acordo com as convicções jurídicas do respectivo juiz ou tribunal, que não está adstrito nem vinculado a nada nem a ninguém. Isso faz com que dois ou mais casos, ainda que extremamente semelhantes, possam ter deslindes totalmente diferentes e antagônicos, a depender de a que órgão jurisdicional coube lhe dar a solução. Imagine-se, por exemplo, uma questão tributária consistente em saber se empresas de um dado segmento empresarial fazem ou não jus a um regime jurídico diferenciado para melhor. Duas empresas deste segmento, ambas concorrentes entre si, ingressam em juízo postulando os respectivos benefícios fiscais, os quais lhes estavam sendo negados pelo poder público. A empresa A vê seu processo distribuído para um juiz que simplesmente acompanha a atual jurisprudência do STF a respeito da matéria e, em decisão singela, a autoriza a se beneficiar do regime fiscal diferenciado. Por sua vez, o processo da empresa B veio a ser analisado por julgador que, reputando equivocada a jurisprudência do STF sobre o tema com base em fundamento jurídico já apreciado e afastado quando o leading case sobre o tema foi julgado, nega à empresa B o direito de gozar dos benefícios fiscais. Em seguida, por contingências de ordem processual, a apelação da empresa B só veio a ser julgada dois anos depois, quando então o tribunal, apenas invocando o entendimento do Supremo Tribunal Federal a respeito do tema, reforma a sentença e concede à empresa $\mathrm{B}$ o direito de participar do regime físcal mais benéfico.

Aí se tem um exemplo completamente factível de ocorrer no modelo brasileiro atual, que não pode ser caracterizado como precedentalista (ao menos ainda não), sem que se possa falar em erro nem conduta indevida de ninguém. A consequência, na hipótese figurada, é que a empresa B esteve, por dois anos, sujeita indevidamente a um regime jurídico fiscal mais gravoso, enquanto a empresa A, sua concorrente no mercado, submeteu-se a um regime melhor. E ambas tinham em seu favor uma questão jurídica já apreciada e decidida pela suprema corte do país, só que nenhum julgador estava necessariamente obrigado a acompanhar o entendimento existente, a pretexto de seu livre 
convencimento e independência funcional.

A depender do caso, isso pode trazer sequelas graves. A empresa A pode ter se aproveitado da situação para, valendo-se dos valores que não precisava mais recolher ao fisco por estar em um regime diferenciado, realizar práticas de atração de pessoas físicas e jurídicas que até então faziam negócios com a empresa B. Esta, por seu turno, mesmo em um contexto de perda de clientes e consumidores, ainda tem de lidar com o pagamento de mais tributos que sua concorrente. Ao final de dois anos, quando só então viu reconhecido seu direito a ter o mesmo tratamento que a empresa $\mathrm{A}$, a empresa $\mathrm{B}$ já não tinha mais condições de permanecer no mercado e termina por encerrar suas atividades, com a demissão de todos os seus empregados. A empresa A, então, agora sem a concorrência da empresa $\mathrm{B}$, aumenta seus preços, em prejuízo de todos os seus clientes, os originais e aqueles que migraram da empresa $\mathrm{B}$, agora extinta.

O exemplo, além poder ser invocado também para tratar de questões ligadas à (falta de) isonomia, mostra que, a pretexto do exercício de uma independência e liberdade, o Poder Judiciário termina por se mostrar dividido, incoerente e contraditório, na medida em que uma decisão anterior de uma corte superior não foi seguida, gerando as consequências mencionadas. Tem-se uma visão pessoal das questões jurídicas, um posicionamento da pessoa de cada juiz, e não uma visão institucional, um posicionamento do Judiciário coletivamente considerado como Poder. Tratando do modelo de precedentes como uma forma de robustecer os órgão distribuidores de justiça como instituição, Frederick Schauer recorda que, como a consistência interna fortalece a credibilidade externa, reduzir a inconsistência interna por meio da obediência aos precedentes pode gerar o fortalecimento como instituição dos órgãos responsáveis pelas decisões. ${ }^{13}$

Além disso, o seguimento de precedentes impede que as decisões dos julgadores de hierarquia inferior sejam reformados pelas cortes superiores. Essa coesão, com todas as instâncias decidindo um mesmo caso de um mesmo jeito, reforça a credibilidade de todas

13 "Se consistência interna fortalece a credibilidade externa, então a minimização da inconsistência interna por meio da estandardização de decisões em seus ambientes de elaboração pode gerar o fortalecimento como instituição destes ambientes de elaboração de decisões" ("If internal consistency strengthens external credibility, then minimizing internal inconsistency by standardizing decisions within a decisionmaking environment may generally strengthen that decision making environment as an institution") (Precedent, p. 19). 
elas e dá aos jurisdicionados a certeza de que, havendo uma regra oriunda de um precedente, é melhor cumpri-la, porque sempre que for questionada ela será imposta, seja por que juízo for.

Assim, a fixação de precedentes de cumprimento obrigatório, em que pese possa representar a diminuição da liberdade da pessoa de cada juiz ou de cada integrante de corte de decidir do jeito que quiser, porque estarão adstritos ao precedente existente, reduz as chances de julgamentos contraditórios e, em decorrência, aumenta a relevância do Poder Judiciário como instituição, com cada julgador passando a ser um componente do sistema judicial visto como um todo, e não apenas individualmente. Nessa perspectiva, até o próprio Supremo Tribunal Federal deve guardar obediência a seus próprios precedentes,

\subsubsection{Função social do Poder Judiciário.}

Tradicionalmente, o Poder Judiciário existe para solucionar conflitos intersubjetivos. Classicamente, existindo um conflito de interesses qualificado por uma pretensão resistida, cabe ao Poder Judiciário resolver a demanda e realizar no plano dos fatos o direito material da parte vencedora. Essa função do Judiciário ainda subsiste e não deixou de ser relevante, até porque representa uma garantia da paz social.

Contudo, a função do Poder Judiciário vai bem mais além do que simplesmente resolver conflitos subjetivos entre as partes ou mesmo resolver as demandas mais complexas que hodiernamente lhe são apresentadas, tais como as ações coletivas versando direitos materiais transindividuais ou ações que versem questões ligadas à condução de políticas públicas. É que, por meio dos casos concretos que soluciona, o Poder Judiciário passa a ser na verdade um garantidor de que o ordenamento jurídico não será observado apenas pelas partes existentes no processo sob julgamento imediato mas por toda a sociedade, já que todos estão submetidos ao mesmo ordenamento. Por isso, ao seguir um modelo precedentalista e fixar regras gerais, abstratas e vinculantes a partir de casos concretos e cuidar para que essas regras sejam realmente observadas nos casos seguintes, o Poder Judiciário na verdade estará criando e reforçando pautas gerais de conduta a serem observadas por todos. Dará, dessa forma, sua importante contribuição para o 
aprimoramento da sociedade e para a obediência das regras jurídicas.

É bom que se esclareça que não se trata aqui de o Poder Judiciário legislar ou realizar qualquer outra função que não seja tipicamente sua. As regras gerais que o Judiciário cria em um modelo de precedentes são fixadas a partir do exercício de sua função própria e típica, que é a de julgar casos concretos. Nesses julgamentos, o Judiciário, naturalmente, interpreta o ordenamento jurídico tal como posto pelos demais poderes. Exatamente como faria em qualquer caso concreto intersubjetivo. O que muda é que, para além de se resolver a demanda específica sob julgamento em si, também se estabelecerá um comando normativo a ser obrigatoriamente observado nos casos posteriores. E não há nada demais nisso, até porque nada impediria que nas hipóteses seguintes o resultado fosse o mesmo, ainda que não existisse um precedente vinculante. Tem-se, pois, uma maneira inteiraente legítima de o Poder Judiciário pautar, no correto exercício de suas funções próprias e típicas, a conduta de toda a sociedade, indicando-lhe como e para onde caminhar, naquilo que talvez represente uma contribuição mais relevante do que a atividade tradicional e clássica de pura e simplesmente solucionar conflitos.

2.4.6. A força normativa da Constituição e o reforço do STF como tribunal constitucional.

O art. 102, caput, da Carta Política de 1988 diz expressamente competir ao Supremo Tribunal Federal (STF) a guarda da Constituição. O controle de constitucionalidade pelo STF se dá pela via direta ou concentrada, à qual se chega por meio das ações de controle concentrado de constitucionalidade (art. 102, I, "a" e $\S \S 1^{\circ}$ e $2^{\circ}$ da Lei Maior de 1988), e pelo método difuso, com destaque para o recurso extraordinário (art. 102, III, da Constituição da República de 1988). Contudo, tendo em vista que o STF simultaneamente detém também uma competência bem ampla para apreciar outras matérias não necessariamente constitucionais (habeas corpus, mandados de segurança a depender da autoridade impetrada, recursos ordinários, determinados conflitos de competência etc.), também nestas causas o STF eventualmente pode vir a proferir decisões em questões constitucionais, reforçando seu papel de guarda da Constituição também por aí. A esse quadro se soma a circunstância de que, no Brasil, o rol de legitimados para o 
ajuizamento de ações diretas de inconstitucionalidade e de ações declaratórias de constitucionalidade é muito amplo (art. 103, I a IX, da Carta Política de 1988), o que permite que diversas causas, teses e questões constitucionais sejam submetidas diretamente ao STF. Além disso, no sistema brasileiro todo juiz pode realizar o controle de constitucionalidade, podendo negar validade a uma lei por reputá-la incompatível com a Constituição, particularidade que aumenta as chances de se ter questões constitucionais mesmo em processos comuns, ficando tal questão constitucional potencialmente sujeita a controle do STF, por meio de recurso extraordinário.

Tal contexto mostra que, no Brasil, o STF exerce um papel fundamental. Além de deter a última palavra em temas constitucionais, também pode ser o último, ou o único, a fixar entendimentos a respeito de matérias não constitucionais (em ações cíveis ou penais originárias, em mandados de segurança, habeas corpus, ilustrativamente). Um precedente do STF, portanto, deve ter um peso e uma consideração bem especial.

Dessa forma, se os precedentes das cortes em geral já devem ser considerados obrigatórios para os julgadores hierarquicamente a ela vinculados, com muito mais razão devem ser vinculantes todos os precedentes do STF, independentemente de terem sido proferidos em controle concentrado de constitucionalidade ou de terem sido compilados e enunciados por meio de súmulas vinculantes. Além disso, a vinculação/obrigatoriedade deve se dar não apenas ao dispositivo da decisão, mas igualmente quanto à ratio decidendi de cada julgado, isto é, a regra de direito geral e abstrata usada pelo STF para resolver o caso deve ser necessariamente observada por todas as cortes nos casos seguintes.

O reconhecimento desta importância do STF e da vinculação/obrigatoriedade de seus precedentes reforça e amplia a força normativa da Constituição. Ora, se seu intérprete maior já registrou dado entendimento a respeito de uma regra contida na Carta Política, decidir-se ou comportar-se de maneira contrária representa uma diminuição da eficácia da Constituição tal como ela foi entendida/interpretada pelo STF. Consequentemente, isso significará também uma diminuição de sua força normativa, porquanto aquilo que o STF disse que a Constituição contém e determina estará restrito a um único caso, sem se espraiar imediatamente para todas as situações semelhantes. 
O cumprimento obrigatório dos precedentes do STF, ademais de representar um fortalecimento da força normativa da Constituição, igualmente exprime um realce na função do STF como tribunal constitucional. Ora, se é a ele - e só a ele - que toca dizer a última palavra em matéria constitucional, não há motivos para se decidir contrariamente ao que já decidiu o STF em tema de interpretação da Constituição, sob pena de se retirar autoridade e credibilidade da corte e obrigar a parte favorecida pelo precedente do STF a, mesmo sendo beneficiada por um precedente da Suprema Corte, ter de percorrer todo o itinerário recursal, com os custos de dinheiro e de tempo daí decorrentes, para que ela repita o que já decidiu antes.

Como foi dito acima, no Brasil o STF, além de ter competências próprias a cortes constitucionais, também apresenta competências que eventualmente podem levá-lo a decidir causas a respeito de matérias não constitucionais. Por exemplo, decidir em habeas corpus se determinada falha ocorrida na quesitação do júri gera ou não a nulidade do processo penal, ou, em mandado de segurança, julgar se o Procurador-Geral da República agiu corretamente ou não na condução de um concurso público ou se o Tribunal de Contas da União cancelou corretamente uma aposentadoria. Considerando a competência que lhe foi dada pela CRFB-1988, esses são temas com os quais o STF pode precisar julgar, sem que isso diga respeito diretamente à guarda da Constituição.

Adotando-se como premissa a obrigatoriedade na observância dos precedentes do STF em matéria constitucional, uma questão interessante que surge é saber se os precedentes firmados pelo STF em causas não constitucionais também seriam vinculantes, mesmo sem que tenham sido proferidos por uma corte com competência para rever decisões dos tribunais nestas matérias. Dito de outra forma: os demais juízes e tribunais devem observância obrigatória aos precedentes do STF relativos a matérias que ele não julga em grau recursal, e sim somente em ações originárias? O problema se impõe porque, na hipótese de descumprimento do precedente vinculante, não existiria à parte prejudicada mecanismo processual para restabelecer a observância do precedente do STF.

Imagine-se a seguinte hipótese: determinada autarquia federal concede 
afastamento remunerado para um seu servidor a participar de um curso de qualificação mesmo durante o período de estágio probatório. O Tribunal de Contas da União, posteriormente, apreciando a legalidade desta medida, diz que somente podem ser concedidos afastamentos remunerados para participação em cursos de qualificação para servidores já estáveis, que tenham cumprido com êxito o estágio probatório. Em consequência desta decisão, determina ao servidor que devolva os valores recebidos durante o período do curso de qualificação. O servidor, então, impetra no STF mandado de segurança impetrado em face desse ato do Tribunal de Contas da União. Figure-se que o STF, então, julga procedente o pedido concedendo a segurança para que os recursos não sejam devolvidos, fixando a regra de que "é possível a concessão de afastamento remunerado para participação em curso de qualificação a servidores em estágio probatório". Uma regra estabelecida a partir um caso desses, que detém todas as características para ser considerada uma ratio decidendi (generalidade, abstração e habilidade para ser aplicada em casos posteriores similares), pode ser tida como obrigatória para as demais cortes, mesmo sem existir remédio processual idôneo a restabelecer sua observância em caso de descumprimento?

Viu-se que um dos fundamentos para a adoção de um modelo precedentalista está na garantia de igualdade entre as partes e no fato de o sistema judiciário ser um todo orgânico hierarquicamente organizado. Dessa forma, apesar de nestes casos realmente não existir instrumento para fazer valer o precedente se ele for desobedecido, não se pode dizer que ele não é obrigatório para os demais julgadores. É sem sentido saber que a Corte Suprema de um país tem um entendimento juridicamente firmado a respeito de um dado assunto e mesmo assim outros tribunais não o observam apenas porque sabem que não haverá com suas decisões serem revistas pela Corte Suprema, criando uma desigualdade entre pessoas com base no órgão jurisdicional competente para julgar suas demandas (se no STF, haveria o direito ao afastamento remunerado; se em outra corte, não) e expondo uma desnecessária e inexplicável violação da hierarquia com base na qual o sistema judiciário foi organizado. 


\subsection{Por que não seguir precedentes?}

O modelo de observância obrigatória de precedentes fixa, a partir da solução de casos concretos, regras gerais e abstratas a serem observadas nos casos assemelhados que ocorram posteriormente. Por conta disso, deve existir no julgador que tem a consciência de que está a estabelecer um precedente uma visão prospectiva relativamente ao conteúdo da regra que está a fixar, precisamente porque ela não se aplicará apenas ao caso concreto no qual está sendo estabelecida mas também a todos as demais hipóteses posteriores semelhantes que eventualmente surjam. Isso pode fazer com que o juiz ou a corte que fixa o precedente finde por optar por um entendimento que não seja o melhor para rigorosamente todos os casos, porque em algum deles pode existir dado pormenor que, acaso não existisse um modelo precedentalista a ser seguido, terminasse por levar à solução distinta daquela determinada pelo precedente. Estes casos representam hipóteses em que a decisão é imperfeita, ou não é a melhor possível.

Com isso se está a dizer que o modelo de observância obrigatória de precedentes permite com que, eventualmente, em um ou outro caso a decisão proferida seja, ainda que parcialmente, errada, ou injusta. E isso, inegavelmente, é um defeito do modelo de precedentes. A opção por seguir precedentes, portanto, deve ser feita com a assumida consciência deste defeito do modelo. A questão é saber se essa imperfeição deve ser tolerada ou não, e em que medida.

Criar um precedente não apenas atento ao caso concreto mas também cioso de que se está a estabelecer uma regra geral e abstrata que doravante será observada mesmo com a ciência de que isso pode significar decisões imperfeitas, erradas ou injustas para um ou outro caso concreto pode sugerir que o modelo é inflexível e desatento às particularidades dos casos. No entanto, essa aparente inflexibilidade representa, na verdade, o outro lado da previsibilidade, da segurança jurídica e da solução mais objetiva dos conflitos. Muito dificilmente se tem como dar previsibilidade e segurança jurídica aos jurisdicionados quando se atenta a todas as particularidades de cada caso concreto. Como é virtualmente impossível que duas situações fáticas sejam rigorosamente idênticas, sempre haverá espaço para dizer que o caso A difere do caso B no aspecto X e, por isso, a decisão de um e de 
outro foi diversa. Só que isso, além de poder gerar a desconfiança de que o caso B não recebeu o mesmo deslinde por razões de ordem subjetiva (amizades, contatos, bastidores, influências), termina por sugerir aos cidadãos a desnecessidade de um descumprimento mais rigoroso e mais sério das regras existentes, ainda que já exista um precedente a respeito delas, porque sempre será possível alegar que, naquele caso, a situação era diversa, a merecer um tratamento diferenciado.

Dessa forma, o defeito do sistema consistente em a decisão do julgado anterior poder não ser a melhor para um ou outro caso no qual ela será aplicada em decorrência da observância do modelo de respeito obrigatório aos precedentes, embora seja real, é superado pelas vantagens existentes e que foram expostas. Para as situações excepcionais em que, acaso seja observado o precedente, a decisão a ser proferida vá ser imperfeita, errada ou injusta em grau tão elevado que, nesse nível de imperfeição, erro ou injustiça nem mesmo o modelo de precedentes deve suportá-la, há os instrumentos da distinção (distinguishing) ou da superação (overruling) do precedente, os quais, apesar de serem de invocação residual e cautelosa, servem justamente para calibrar o modelo precedentalista nestes casos em que a observância pura e simples do precedente começa a ter mais contras que prós, a fazer mais mal que bem.

\subsection{Os precedentes não violam o princípio da legalidade.}

O princípio constitucional da legalidade, segundo o qual ninguém será obrigado a fazer ou deixar de fazer alguma coisa senão em virtude de lei (art. 5º, II, da CRFB-1988) não é abalado pelo reconhecimento de que existe, em um precedente, uma ratio decidendi a qual consiste em um regra geral e abstrata a ser aplicada de modo vinculado a casos posteriores. Na verdade, o Poder Judiciário, ao aproveitar um caso concreto para a partir dele criar uma regra geral e abstrata a ser posteriormente observada de maneira obrigatória não está legislando. O que existe é a utilização de um caso, um leading case, que será concretamente decidido como qualquer outro, fazendo uso regular da legislação existente e aplicando o direito ao caso concreto. Contudo, de modo subjacente a essa decisão do caso concreto, a corte passa por uma etapa prévia que é o estabelecimento de uma regra jurídica aplicável ao caso. É essa regra jurídica que, além de servir de base para a solução do 
leading case, desprender-se-á do caso concreto e ganhará ares de generalidade e abstração, passando a ser aplicável também a casos futuros.

É importante se ter presente que tal regra jurídica reconhecida pela corte não inova em nada no ordenamento para além daquilo que já seria função típica do Poder Judiciário. Como se disse, à regra se chega por meio da interpretação e aplicação do ordenamento jurídico, do mesmo jeito que ocorre em rigorosamente qualquer outro caso. $\mathrm{O}$ que acontece é que a tese, o entendimento do tribunal a respeito de como o ordenamento jurídico deve ser aplicado e interpretado é exprimido por meio de uma regra que passa a ser de observância e cumprimento obrigatório pelos órgãos jurisdicionais vinculados. Mas não existe, em nenhum momento, uma criação propriamente de direito novo. O Poder Judiciário vai até onde sempre foi em seu papel de interpretar e aplicar o direito já existente. O resultado dessa interpretação e aplicação é que passa a ser vinculante, como uma forma de evitar decisões conflitantes, garantir isonomia, previsibilidade, segurança jurídica e racionalidade ao sistema. Em vez de precisar ficar repetindo, em cada caso semelhante, a mesma decisão (porque presente a mesma regra jurídica), no modelo precedentalista a opção é pela extensão, desde logo, da regra jurídica para todos os casos, por meio da concessão de efeito vinculante ao precedente.

Cândido Rangel Dinamarco afirma que “(...) a outorga de caráter vinculativo a decisões judiciárias, que equivale a dotar os tribunais de poder normativo e alterar a tradicional fórmula brasileira de separação entre os chamados Poderes do Estado (...)" e que “(...) se a questão é político-institucional na medida da reformulação trazida ao sistema de checks and balances constitucionais, era necessário ter a coragem de dar-lhe solução política, porque já se sabia que em regras puramente técnicas de direito processual nenhum resultado eficaz se poderia jamais encontrar". ${ }^{14}$ A rigor, conceder efeitos vinculantes aos precedentes dos tribunais não é propriamente dar a eles o poder de editar normas, ainda que a porção vinculante do precedente seja justamente a regra jurídica geral e abstrata que serviu de fundamento para a decisão. Afirma-se isso porque, conforme dito acima, ao estabelecer um precedente que se aplicará obrigatoriamente a todos os casos futuros semelhantes nenhum tribunal faz nada além, nem diferente, do que ele já faria se a decisão fosse ficar confinada apenas ao caso concreto. Não existe nenhuma invasão do ${ }^{14}$ Súmulas vinculantes, p. $218-219$ (destaques existentes no original). 
espaço próprio do Poder Legislativo, que não vê reduzidas, sequer indiretamente, suas competências constitucionais, as quais seguem plenas. Observe-se que, em essência, tanto faz o tribunal decidir o caso $\mathrm{X}$ e afirmar que a regra jurídica que usou para solucionar a demanda se aplica obrigatoriamente aos casos $\mathrm{Y}$ e $\mathrm{Z}$ (precedente vinculante) quanto $\mathrm{o}$ próprio tribunal julgar os casos $\mathrm{X}, \mathrm{Y}$ e $\mathrm{Z}$ aplicando em todos eles essa mesma regra jurídica. O resultado final é o mesmo e corte não inova em nada suas relações com o Poder Legislativo. Se há alguma mudança decorrente da adoção do modelo precedentalista ela se dá internamente, dentro do próprio Poder Judiciário, que passa a ser visto não numa perspectiva individualizada de cada julgador, mas sim como órgão, como instituição, constituindo um corpo engrenado que tem de funcionar coerentemente. Mas isso nada tem a ver com poder normativo.

Na verdade, e de certo modo, o uso da técnica de precedentes vinculantes pode ser visto como uma forma de resolução coletiva de conflitos. Existem, e a jurisdição coletiva dá conta disso, ações e sentenças específicas voltadas à solução em um só processo de várias demandas agrupadas ou de demandas comuns a várias pessoas. Por meio de uma só propositura, uma só instrução e um só julgamento, várias contendas são resolvidas. Esta é uma forma extremamente racional de resolução de problemas de massa, porque, além de garantir igualdade, evita a pulverização e a repetição de demandas idênticas.

A técnica de decisão com fundamento em precedentes vinculantes, embora não impeça diretamente o ajuizamento de ações repetidas, garante a solução idêntica a todos os casos. Uma vez fixado o precedente e sendo ele de observância obrigatória pelos julgadores de hierarquia inferior, tem-se a certeza de que os casos iguais ou assemelhados receberão o mesmo tratamento e deslinde. Nessa perspectiva, não é incorreto falar-se que o precedente configura uma decisão coletiva, porque a generalidade, abstração e vinculação que marcam a regra contida no precedente garantem que o entendimento será aplicado a todos os casos semelhantes, atuais e futuros.

Quando um tribunal de hierarquia superior edita um precedente, isto é, uma regra jurídica a respeito de dada situação, na prática tanto faz dizer que esta regra se aplica obrigatoriamente a todos os casos semelhantes como não determinar vinculação nenhuma 
mas, em todos esses casos, este tribunal superior aplicar o mesmo entendimento quando os respectivos processos lhe chegarem em grau recursal. Pragmaticamente, o resultado final será o mesmo. O entendimento vai acabar prevalecendo. O que muda é o que acontece no caminho, no intervalo entre a decisão que não aplica o precedente e aquela outra que o restabelece. Por isso é que se diz que entre uma e outra opção há diferenças substanciais. Quando se confere vinculação e obrigatoriedade aos precedentes, as partes e os profissionais jurídicos já tem como antecipar seu resultado de maneira segura, porque onde e a quem seja a causa submetida, a decisão será a mesma, isto é, obedecer-se-á o precedente. Quando essa vinculação não existe e os entendimentos são aplicados apenas por meio do recurso cabível, durante o caminho até a decisão da corte estabelecedora do precedente a parte a quem o entendimento favorece perdeu tempo, recursos e pode ter perdido oportunidades. Ademais disso, esse modelo que permite aos julgadores inferiores decidir livremente, forçando aquele a quem o precedente (não obrigatório) favorece a ter de recorrer para fazer com que ele prevaleça, estimula a litigância e a protelação.

Dessa forma, vê-se que, em essência, dar ou não caráter obrigatório aos precedentes na verdade é uma mera técnica de solução de conflitos, que não altera em nada as relações naturais e tradicionais que a atividade jurisdicional sempre teve com o princípio da legalidade.

\subsection{Caráter prospectivo da decisão em um sistema precedentalista (o olhar} para frente)

Quando se fala em precedente, talvez a primeira ideia que ocorra seja a de se invocar o passado, olhar-se para algo que já aconteceu e ver-se como uma dada questão foi resolvida anteriormente. Essa ideia é verdadeira, mas corresponde a apenas parte das questões relacionadas ao emprego da técnica de precedentes como forma de solução de demandas judiciais. Tão importante quanto as cortes saberem que precisam obedecer ao que foi decidido anteriormente é elas saberem que, ao julgar temas inéditos (ou ao rever regras até então estabelecidas e observadas), estão fixando regras para o futuro. Como diz Frederick Schauer, “o hoje não é apenas o amanhã de ontem; também é o ontem de amanhã. Um sistema de precedentes consequentemente envolve uma especial 
responsabilidade, que acompanha o poder de vincular o futuro antes de se chegar nele". ${ }^{15} \mathrm{~A}$ consciência dessa bidimensionalidade, dessa relação presente-passado mas também presente-futuro permite que se compreenda com mais facilidade que não é só a corte do caso subsequente que tem deveres (de considerar e de obedecer o precedente) mas também os tem o julgador do caso original, que, ao fixar o precedente, deve obedecer a certos critérios e ter certas preocupações.

Embora em um modelo precedentalista ainda seja possível julgar "conforme as particularidades do caso concreto", sugerindo que aquela decisão, em si, não deve ser tomada como um verdadeiro precedente, na verdade o juiz em um sistema de precedentes está vinculado ao precedente quer quando já existe um que deve ele cumprir, quer quando não tem um julgado anterior a obedecer. Neste último caso, em que não existe precedente a ser observado, a presença do modelo de precedentes se dá pela existência da necessidade de que o julgador tenha a consciência de que a decisão que proferirá será inédita, a primeira sobre dado tema e que, por isso, ela deverá ser tratada como precedente pelos demais juízes. Dessa forma, sabe ele que tal decisão será seguida em casos similares e que portanto a decisão a ser proferida não é apenas a decisão daquele específico caso concreto mas também representa o estabelecimento de uma regra geral que se estenderá a outros casos. Isso leva a decisões mais refletidas, mais responsáveis, mas atentas ao que se está decidindo, a que regra está sendo criada. Pode-se dizer que, em um modelo de precedentes, toda decisão que julga um tema pela primeira vez (ou que expressamente afasta um precedente já existente, pondo outro no lugar) é uma decisão coletiva, que abarcará não só o caso em que foi proferida mas também outros que se seguirão. Por isso é que se pressupõe que o juiz, sabendo que sua decisão vinculará outras, decidirá o que é melhor não só para o presente caso, mas igualmente para os futuros que lhe sejam semelhantes. Essa característica aumenta a responsabilidade dos julgadores, na medida em que a consequência de suas decisões invariavelmente será mais amplo do que seria se apenas o julgamento do caso concreto fosse levado em conta. A decisão há de levar em conta para decidir o caso razões predominantemente objetivas, justamente para que o precedente tenha a habilidade de se estender universalmente para os casos semelhantes, sem apego

15 "Today is not only yesterday's tomorrow; it is also tomorrow's yesterday. A system of precedent therefore involves the special responsibility accompanying the power to commit the future before we get there" (Precedent, p. 2). 
demasiado a situações particulares ou subjetivas.

Por força da necessidade de atuar desse jeito, com uma consciência atual mas também prospectiva, existe a possibilidade de que a decisão na qual o precedente está sendo estabelecido não seja a melhor para o respectivo caso concreto, já que ela está sendo tomada não apenas para o presente caso, mas também almejando fixar uma regra para ser obrigatoriamente observada no futuro. Ou seja, a decisão tomada ao se fixar um precedente pode não ser a melhor, nem necessariamente a mais justa, para o caso individualmente considerado, mas ser a melhor regra a ser fixada, tendo em vista que ali se estará a fixar não só a regra específica, mas também a regra geral de observância obrigatória nos casos futuros. Isoladamente, a solução do precedente pode nem ser a melhor em razão da existência de particularidades de ordem subjetiva, mas objetivamente, pensando-se na regra jurídica geral e abstrata que será repetidamente aplicada nos casos futuros, é a melhor solução a ser dada. A percepção dessa característica do modelo precedentalista, segundo a qual a decisão há de ser tomada com atenção não apenas à solução do caso concreto em si, mas também à regra jurídica a ser criada, leva à constatação de que o uso de precedentes leva a uma natural impessoalização das decisões judiciais. Isso porque o julgador que estabelece o precedente não se sente estimulado a incluir nele uma regra jurídica que não vai querer ver repetida em todos os casos seguintes e também porque o juiz do caso posterior, adstrito que está ao precedente e à regra nele existente, não tem muita margem para incluir nele razões de ordem particular ou subjetiva.

Essa possibilidade de existir decisões parcialmente inapropriadas para um dado caso concreto é admitida pelo sistema de precedentes justamente para garantir que várias decisões futuras - aquelas que seguirão o precedente - serão corretamente proferidas e, portanto, mais justas. O sistema aceita que em um momento mais imediato algumas decisões não sejam perfeitas, porque isso representa em essência um inconveniente necessário para que o direito seja coletivamente melhor aplicado, na perspectiva dos casos futuros, ainda que com eventuais prejuízos iniciais. ${ }^{16}$ Como não é sempre que a decisão do

\footnotetext{
${ }^{16}$ Ficou muito conhecida a frase, contida no voto vencido proferido pelo Justice Louis Dembitz Brandeis em Burnet v. Coronado Oil \& Gas Co., segundo a qual, apesar de afastar-se do precedente ser sempre uma possibilidade, "o stare decisis é normalmente a política mais sábia, porque na maioria dos temas é mais importante estabelecer a regra jurídica do que estabelecê-la corretamente" ("stare decisis is usually the wise policy, because in most matters it is more important that the applicable rule of law be settled than that it be settled right”) [Burnet v. Coronado Oil \& Gas Co., 285 U.S. 393 (1932)].
} 
caso concreto também não será a melhor solução também para os casos futuros, isto é, como o normal, o esperado é que a solução do caso concreto no qual está sendo fixado o precedente igualmente seja a melhor solução para as hipóteses futuras, o sistema termina por aceitar e admitir que, em alguns casos, seja praticada alguma injustiça no caso fixador do precedente justamente para que ele, o precedente, contenha uma regra geral melhor para os casos futuros. Um bom resumo da questão é dado por Frederick Schauer ao dizer que a confiança nos precedentes implica abrir mão da melhor solução em todos os casos em favor da diminuição das chances de erro em alguns casos. ${ }^{17}$

Isso pode parecer errado, notadamente para a parte em prejuízo da qual isso acontece, mas, analisando-se o problema na perspectiva do sistema precedentalista e daquilo a que ele se propõe, não é. Trata-se de um preço que se paga pela isonomia, previsibilidade, segurança jurídica. Afigura-se preferível alguma injustiça ou erro em um específico caso, mas acerto em vários outros ${ }^{18}$, do que, para supostamente não se errar em um dado julgamento concreto, deixar a questão jurídica indefinida e não resolvida para o futuro (o que pode acontecer quando não há um modelo de precedentes ou quando, mesmo existindo, a corte expressamente diz que aquela decisão não representa um precedente, por ter sido proferida considerando apenas as particularidades daquele específico caso) ou fixar um precedente com base na decisão certa para apenas aquele caso concreto, mas incorreta para os casos futuros, uma vez que um precedente assim fixado corre o sério risco de, já no curto prazo, ter de ser considerado superado ou de alguma forma revisto, o que traz a instabilidade e a insegurança jurídica que o sistema de precedentes almeja evitar. ${ }^{19}$ Por isso

\footnotetext{
17 "It thus becomes plain that adopting a strategy of reliance on precedent is inherently risk averse, in the sense of giving up the possibility of the optimal result in every case in exchange for diminishing the possibility of bad results in some number of cases (Precedent, p. 13).

${ }^{18}$ Frederick Schauer adverte que seguir um modelo de precedentes beneficiando-se de suas vantagens e aceitando a desvantagem de o precedente poder não ser a melhor solução para um dado caso concreto isoladamente considerado pode ser mais fácil ou mais difícil a depender do assunto tratado. Assumindo que o exemplo é extremado, ele explica que é muito mais fácil tolerar, em nome da previsibilidade e da igualdade, decisões imperfeitas para um ou outro caso matéria de contratos do que ainda que para só um caso que possa gerar pena de morte. Aqui ele diz que a justiça tem de ser feita com cada caso sendo analisado em detalhes, sem preocupações com os valores decorrentes de um modelo precedentalista (Precedent, p. 18).

${ }^{19}$ Em uma universidade, um aluno pede para faltar ao último exame para ir ao velório de seu irmão. No caso concreto, a solução mais justa e recomendável seria entender justificada a ausência e permitir que o aluno vá ao velório. No entanto, ao refletir sobre o precedente que será fixado, a universidade pode ter o receio de que a decisão seja posteriormente interpretada como permitindo a ausência do aluno sempre que algum parente ou ente querido faleça, o que lhe soa demasiadamente amplo e, por isso, para evitar que tal aconteça, indefere o pedido do aluno para se ausentar no dia do exame, mesmo que para comparecer ao velório do seu irmão. Frederick Schauer usa este exemplo para mostrar que, em um sistema de precedentes, a melhor decisão em geral e para a maioria dos casos não necessariamente é a mais indicada para dado caso concreto, mas que isso deve ser suportado como um custo natural a ser dispendido para se extrair as vantagens do sistema
} 
é que, no modelo de precedentes, a decisão leading case pode vir a receber severas críticas acaso não seja observado que a solução por ela apontada pode ter sido motivada não apenas pela solução do caso concreto propriamente, mas pela preocupação de criar uma melhor regra geral a ser observada e repetida em hipóteses posteriores.

Evidentemente, o estabelecimento de um precedente não pode gerar decisões imperfeitas, injustas ou erradas na maioria dos casos. Para a obtenção de uma regra geral mais justa e mais perfeita para a maioria dos casos, o sistema aceita que, eventualmente, em um ou outro caso a decisão não seja a melhor, não seja aquela que seria proferida acaso não se tivesse que observar (ou fixar) a regra geral contida no precedente. Contudo, quando essas decisões imperfeitas deixam de ser acidentais e passam a se tornar frequentes, começa a chegar a hora de rever a regra geral e afastar-se do precedente, que iniciou seu processo de superação e sobre isso se discorrerá oportunamente quando se tratar da revogação (overruling).

\subsection{Precedentes e hierarquia das cortes.}

No modelo precedentalista verdadeiro os precedentes são cumpridos porque o Poder Judiciário é uno, é orgânico, é racional, é hierarquicamente organizado (trata-se de uma organização, não de uma divisão) e é sistemático. A independência funcional de cada julgador é exercida dentro dessas balizas. Por isso é que nenhum juiz, seja de que instância for, se sente diminuído ou menos independente apenas porque tem de seguir uma regra geral, abstrata e vinculante elaborada por algum órgão jurisdicional de hierarquia superior.

Depois de ter realçado a importância da segurança jurídica para o direito e para a vida em sociedade, Cândido Rangel Dinamarco salienta que “(...) a divergência de julgados é elemento extremamente comprometedor dessa segurança e desagregador da harmonia social. A servidão do juiz à lei, a exaltação do caráter impessoal do exercício da jurisdição e a limitação do poder de interpretação judiciária são expressões da necessidade de oferecer segurança". Em seguida, o autor faz questão de consignar: "sou declarado defensor da grande liberdade interpretativa do juiz, mas essa liberdade não pode ser absoluta a ponto de ele julgar segundo seus sentimentos pessoais e não como canal de (Precedent, p. 13). 
comunicação entre os valores da sociedade e o caso em que atua. O que está à base deste pensamento é a regra da impessoalidade no exercício da jurisdição. Por outro lado, interpretações conflitantes geram incertezas e insegurança". ${ }^{20}$

Nesse contexto, a vinculação a precedentes pressupõe obediência e eficácia vertical (hierárquica) e horizontal (respeito pela própria corte). O cumprimento dos precedentes pelos tribunais de hierarquia inferior se justifica pelas razões expostas no item 2.4 e também com base na hierarquia e organicidade. Já a obediência aos próprios precedentes também é justificada pelas razões mencionadas no item 2.4 e também pelo exemplo. Se a própria corte começa a ser incoerente com seus julgados, isso pode levar a que as outras cortes passem a vê-la com desconfiança, incredulidade e insegura, o que poderia levar à desobediência também pelos tribunais de hierarquia inferior. Além disso, se uma corte começa a não honrar seus próprios entendimentos, isso pode gerar uma violação à isonomia no tempo. Alguém que teve sua causa julgada há pouco tempo obteve dado resultado e outra pessoa, pouco tempo depois, na mesma corte, obteve resultado distinto.

Se uma corte encontrar precedentes em sentido diverso vindo de cortes distintas, deve optar por respeitar o precedente de maior hierarquia, já que o outro provavelmente surgiu em seu descumprimento.

Esse assunto voltará a ser abordado quando se estiver cuidando da distinção e da revogação de precedentes.

\footnotetext{
${ }^{20}$ Súmulas vinculantes, p. 237 (destaques existentes no original). De maneira semelhante, Eduardo Cambi salienta: "Respeitar a jurisprudência dominante dos tribunais superiores não é retirar do juiz ou dos tribunais o livre convencimento nem sua independência. Sabendo-se que cabe aos tribunais superiores dar a última palavra, a decisão que contraria a jurisprudência consolidada revela desprezo pelo Poder Judiciário e, especialmente, total desconsideração pelos usuários do serviço jurisdicional, que, pela vaidade pessoal do magistrado, são compelidos a recorrer para, só então, ter seus direitos tutelados" (Neoconstitucionalismo e neoprocessualismo - direitos fundamentais, políticas públicas e protagonismo judiciário, p. 161).
} 
RATIO DECIDENDI

3.1. Ratio decidendi: considerações gerais. 3.2. Métodos de identificação da ratio decidendi do precedente. 3.3. A extensão da ratio decidendi. 3.4. A mutabilidade posterior da ratio decidendi. 3.5. Expansão dos precedentes. 3.5.1. Involuntária/inconsciente. 3.5.2. Voluntária.

\subsection{Ratio decidendi: considerações gerais.}

Em um modelo precedentalista, de cada caso julgado pode vir a ser extraída uma norma geral e abstrata que, ademais de se aplicar e servir de fundamento para o próprio caso concreto, também passa a ser invocável e aplicável de modo obrigatório em outros casos, pelos motivos expostos no item 2.4.

Para que se saiba qual é a norma vinculante que emerge da decisão proferida em cada caso concreto, ou mesmo para que se verifique se um caso posterior está mesmo obedecendo de maneira correta a regra de observância obrigatória estabelecida pela decisão proferida em um caso anterior, é preciso que se conheça os fatores que individualizam cada um dos casos, ou seja, é imperioso que se saiba quais são os elementos que efetivamente marcam e caracterizam a hipótese concreta anterior e posterior, para que se tenha segurança a respeito do que foi decidido e de qual é a norma vinculante correta emanada do precedente. Assim, a regra vinculante a ser observada pelo caso posterior é extraída desses elementos essenciais definidores do caso anterior, ou seja, para a obtenção da regra obrigatória estabelecida pelo caso anterior é imperioso que se analise as razões pelas quais o caso foi decidido de um jeito, e não de outro. É a partir dessas observações que se consegue retirar, de um caso inicialmente concreto e específico para as partes nele envolvidas, uma regra geral e abstrata, a servir de orientação para os casos futuros. 
A ratio decidendi ou holding ${ }^{21}$ é exatamente essa regra extraída do caso anterior e à qual o caso posterior tem de dar cumprimento de maneira vinculada. Observe-se que, não obstante costumeiramente se dizer que a respeito de tal ou qual matéria já existe um precedente ou que o tribunal fixou um precedente sobre dado assunto, na verdade o que é de cumprimento obrigatório para os casos futuros não é propriamente todo o julgado precedente, mas somente sua ratio decidendi, isto é, apenas uma parcela da decisão proferida $^{22}$. E o conceito do que é de cumprimento obrigatório em um precedente - ratio decidendi - pode ser mais ou menos amplo, sendo que daí advém consequências importantes. Conforme a extensão daquilo que é considerado como sendo a parte obrigatória do precedente, maior ou menor liberdade terá o julgador do caso posterior, ou seja, muda o grau de flexibilidade na apreciação do caso seguinte.

Para que se identifique, em um determinado precedente, qual é sua ratio decidendi - aquela sua parte que terá de ser observada pelos casos seguintes - é preciso que se aprecie o seguinte: (a) a demanda submetida ao Poder Judiciário; (b) os fatos considerados relevantes para a solução do caso; (c) a fundamentação jurídica utilizada e (d) o que efetivamente restou decidido. ${ }^{23}$ Esse conjunto de elementos configura a razão (ou as razões) de decidir do julgador, os fatores que o levaram a decidir de dada maneira, e não de outra. São os porquês da decisão ter sido a que foi, e não uma outra. É a partir deles que se obtém a regra jurídica de que o julgador lançou mão, expressamente ou não, para decidir o caso, a qual será tida por vinculante para os casos posteriores semelhantes. Trata-se da ratio decidendi.

É preciso salientar que a ratio decidendi não se confunde com a fundamentação da decisão, ou ao menos não se confunde integralmente com ela. Proceder a essa distinção é ainda mais importante no estágio atual do modelo processual brasileiro, que se encontra,

\footnotetext{
${ }^{21}$ As expressões ratio decidendi e holding são sinônimas, ambas se reportando à porção do precedente que é vinculante para os casos posteriores. A primeira (ratio decidendi) é de uso mais comum no direito inglês, enquanto a segunda (holding) é mais frequente no direito estadunidense. Conferir Celso de Albuquerque Silva, Do efeito vinculante - sua legitimidade e aplicação, p. 182 e Fredie Didier Jr., Paula Sarno Braga e Rafael Oliveira, Curso de Direito Processual Civil, v. 2, p. 385.

${ }^{22}$ De todo modo, até para que não se fuja da terminologia convencional e já conhecida e difundida no Brasil, também neste trabalho se mencionará precedente mesmo quando, em denominação mais precisa, a referência fosse na verdade apenas à ratio decidendi do precedente, ou seja, tomar-se-á um pelo outro indistintamente, na tentativa de facilitar a fluidez do texto e sua clareza.

${ }^{23}$ Neste sentido: Patrícia Perrone Campos Mello, Precedentes - o desenvolvimento judicial do direito no constitucionalismo contemporâneo, p. 120.
} 
pode-se dizer, em uma fase de transição entre institutos de civil law e de common law. Para que não ocorram confusões nem impropriedades terminológicas, deve ser esclarecido que nos julgados proferidos em um sistema de precedentes obrigatórios existe (1) a decisão proferida no caso concreto (o dispositivo, isto é, a solução específica da demanda, exatamente como ocorre no direito brasileiro), (2) a fundamentação para essa decisão (igualmente de modo semelhante ao que acontece no Brasil) e também (3) a ratio decidendi, que é a parte da decisão que é genérica e abstrata (não adstrita às partes no processo nem à situação concreta nele discutida) e de observância obrigatória para os casos posteriores.

Seja qual for o método que se adote para definir o que é ratio decidendi ou para identificá-la em um dado julgado (e sobre os métodos de identificação da ratio decidendi se discorrerá mais abaixo), e seja esse critério ampliativo ou restritivo daquilo que é o comando obrigatório do precedente, o importante é saber que ele não é a mesma coisa que fundamentação, tampouco idêntico ao dispositivo. A ratio decidendi é um instituto diverso tanto da fundamentação quanto do dispositivo mas, em essência, não prescinde deles na medida em que para se saber qual é o comando genérico e abstrato fixado por um dado precedente e que deve ser cumprido obrigatoriamente nos casos posteriores (ou seja, para se saiba qual é a ratio decidendi) é preciso analisar a decisão proferida, inclusive sua fundamentação e seu dispositivo, além de outros fatores, como o pedido apresentado pela parte e os fatos considerados importantes pela decisão. Essa análise permitirá observar qual foi a regra jurídica usada pelo juiz, expressamente ou não, para decidir o caso. Assim, embora seja um instituto diverso, o estudo da fundamentação segue sendo um instrumento importante para a identificação da ratio decidendi de um caso. ${ }^{24}$ Contudo, justamente por não se confundir com a ratio decidendi, a fundamentação em si não é vinculante, característica que só a ratio decidendi detém. A ratio decidendi, portanto, é um tertium genus relativamente à fundamentação e ao dispositivo, que não se confunde com eles mas que deles precisa para ser apreendida e compreendida. Na perspectiva do direito brasileiro, é um instituto novo, que carece de ser bem estudado, para que esse movimento de

\footnotetext{
${ }^{24}$ Patrícia Perrone Campos Mello, inclusive, realça “(...) que a motivação é absolutamente essencial para se formular o comando geral que emergirá do precedente (...)" porque “(...) é nela que se encontram a identificação dos fatos relevantes, a definição da questão de direito e os debates travados em torno dos dois primeiros elementos" (Precedentes - o desenvolvimento judicial do direito no constitucionalismo contemporâneo, p. 124).
} 
crescente adoção de institutos egressos do common law aconteça corretamente, sem os atropelos que podem ocorrer quando se importa instrumentos sem a devida atenção teórica e prática ao contexto em que estão inseridos.

A ratio decidendi de um precedente é, assim, a parte de uma decisão que contém uma regra jurídica geral e abstrata mais ou menos ampla que deve obrigatoriamente ser observada nos julgados seguintes. Não se confunde com a fundamentação nem com o dispositivo da decisão, mas é apreendida a partir da análise deles em conjunto com os fatos e o pedido formulado. Daí a relevância, para que se saiba o que efetivamente é vinculante em um julgado pretérito e a que regras os julgadores estão obrigados ao apreciar os casos seguintes, do estudo da fundamentação do precedente, principalmente no Brasil, onde ainda não se tem muito definida na prática a noção de ratio decidendi. Embora no Brasil se use o que foi decidido no passado como argumento em prol pretensões deduzidas em juízo ou como fundamento para decisões judiciais, ainda não está sedimentada a compreensão da ratio decidendi como uma regra geral, autônoma, abstrata e que se desprende do caso concreto em que foi estabelecida para se estender e se aplicar também aos casos seguintes assemelhados.

Em decisões mais intrincadas, nas quais mais de uma fundamentação é empregada, cresce a complexidade e a importância de se delimitar com mais precisão qual é efetivamente a porção vinculante do precedente. Isso porque os argumentos usados pela corte podem ser autônomos ou cumulativos, ensejando consequências distintas conforme o caso. Na hipótese de para uma mesma conclusão o tribunal ter feito uso de diversos fundamentos, cada um deles suficiente, só por si, para justificar a decisão proferida, podese ter mais de uma ratio decidendi extraível de um mesmo caso. Já nas situações em que as fundamentações utilizadas precisam ser somadas para que se obtenha a conclusão da corte, tem-se uma só ratio decidendi, consistente justamente no conjunto desses argumentos.

Observe-se que, nos dois casos (fundamentos autônomos ou cumulativos), é possível que argumentos tenham sido utilizados e mesmo assim não consubstanciem ratio decidendi. É quando o fundamento é mero reforço, ou é indiferente para a decisão da corte. É o que se chama de obiter dictum. Qualquer porção do julgamento da corte que não 
corresponda exatamente aos fundamentos usados para decidir o caso, é mero obiter dictum, ou seja, não é ratio decidendi e, por não sê-la, não vincula os casos futuros. Pode-se afirmar que ao obiter dictum se chega por exclusão. O que não for ratio decidendi (e como se encontra a ratio decidendi de um caso é matéria controvertida até hoje mesmo nos países que originalmente sempre adotaram o modelo precedentalista, e sobre ele se discorreu no item 3.2) é obiter dictum, vale dizer, tudo o que não tiver relação direta e necessária com o deslinde do caso concreto, por não ser ratio decidendi, é obiter dictum. ${ }^{25}$ Enquadram-se aí os votos vencidos, os argumentos rejeitados ou não apreciados pela corte ou as considerações laterais dispensáveis, ainda quando feitas a título de reforço de argumentação e mesmo que lançadas por unanimidade.

A explicação para se chegar à noção de obiter dictum por exclusão é simples. Como a ratio decidendi é uma regra geral e abstrata extraída da solução dada a um caso concreto (mas que não se confunde com esta solução, nem com os fundamentos para ela), naturalmente tudo o que não for essencialmente parte da solução dada ao caso concreto não integra a ratio decidendi. Conforme já mencionado anteriormente, a conclusão a respeito de qual é a ratio decidendi de um determinado precedente exige que se aprecie, dentre outros fatores, qual foi a demanda submetida ao Poder Judiciário e quais foram os fatos considerados relevantes para a solução do caso. Acaso se permitisse extrair vinculação a partir de considerações feitas sem ligação direta com o deslinde do caso concreto em última análise se estaria autorizando a fixação de uma regra geral, abstrata e vinculante (a ratio decidendi) a partir de considerações também com um certo caráter abstrato, precisamente porque desvinculadas diretamente da solução concreta dada ao caso. Ao Poder Judiciário, em regra, não é dada a função de resolver abstratamente controvérsias, daí resultando que a fixação de precedente obrigatório a partir de fatores não ligados ao caso concreto extrapolaria a função típica do Judiciário. Aliás, é precisamente porque a parte vinculante do precedente vem da solução de um caso concreto que se entende perfeitamente legítimo o modelo precedentalista. O Poder Judiciário não está invadindo a

\footnotetext{
25 "A ratio decidendi abarca a argumentação judicial considerada absolutamente básica, necessária e indispensável para servir de suporte direto para a resolução da questão jurídica. Por isso, possui caráter vinculante. Em contrapartida, o obiter dictum (ou 'aquilo que é dito para morrer') versa sobre simples reflexão utilizada para motivar o caso concreto, mas que não é indispensável para a decisão da questão jurídica. Serve, destarte, de mero critério auxiliar de interpretação, com força meramente persuasiva, a depender do prestígio e da hierarquia do tribunal, sem possuir poder vinculante sobre os demais juízes ou tribunais" (Eduardo Cambi, Neoconstitucionalismo e neoprocessualismo - direitos fundamentais, politicas públicas e protagonismo judiciário, p. 153 - grifos existentes no original).
} 
órbita de atuação do Poder Legislativo exatamente porque a regra geral, abstrata e de observância obrigatória que cria na ratio decidendi advém do correto exercício de uma função que é sua, consistente na solução dos casos concretos que lhe são postos a julgamento (item 2.6).

Embora o obiter dictum não possua um obrigatório caráter vinculante, é inegável que ele pode ser dotado de uma eficácia persuasiva, que será maior ou menor a depender de seu conteúdo, extensão, relevância e profundidade. Poderá, inclusive, servir de fundamentação para outros julgados, apesar da ausência de vinculação. Conforme Patrícia Perrone Campos Mello, os tribunais podem conferir ao obiter dictum “(...) algum peso impositivo quando houver a evidência de que resultou de um exame especialmente atento da corte, ainda que não fosse necessário à decisão", ${ }^{26}$

No sistema brasileiro existe uma complexidade ainda maior na determinação precisa de qual é a ratio decidendi de um precedente e do que é mero obter dictum (entendido este como tudo o que não for ratio decidendi). É que às vezes um julgamento colegiado proferido é baseado na soma de argumentos convergentes a um dado resultado, cada um desses argumentos constantes do voto de um dado julgador, ou de apenas alguns deles. Dessa forma, apesar do argumento ter constado no voto de um ou de alguns juízes, seu conteúdo não necessariamente foi enfrentado pelo tribunal como um todo, não se podendo dizer que existe uma deliberação da corte sobre o assunto, seja ele qual for. Assim, a conclusão a que chegou o tribunal pode até ter sido unânime, ou seja, pode até ter existido uma uniformidade no acórdão, no dispositivo da decisão por assim dizer, mas as razões que levaram a essa conclusão podem ser completamente distintas a depender da fundamentação do voto deste ou daquele julgador.

Com isso, pode-se ter situação em que, apesar de a conclusão ter sido a mesma nos votos de vários juízes de uma corte, as justificativas de cada um deles para tal conclusão não serem as mesmas. E aí surge a interessante questão em saber se existe ou não uma ratio decidendi em um julgamento com essa particularidade e, se existir, qual é ela. Isso se explica porque às vezes um dado fundamento pode ter sido mencionado por algum integrante da corte mas não ter sido sequer apreciado nem referido pelos demais, de ${ }^{26}$ Precedentes - o desenvolvimento judicial do direito no constitucionalismo contemporâneo, p. 126. 
modo que não se pode falar que a corte apreciou efetivamente o tema, quer para encampálo, quer para rejeitá-lo. E, se não tiver mesmo apreciado aquele específico fundamento, não pode ser ele considerado quando se for verificar qual é a ratio decidendi, apesar de ter sido usado como fundamento no voto de algum julgador. ${ }^{27}$

No limite, aliás, em tese é possível que um dado julgamento colegiado seja proferido a respeito de um tema extremamente importante para todo o país, o resultado desse julgamento seja unânime, tenha-se uma solução para o caso concreto mas não aconteça o estabelecimento de nenhuma ratio decidendi. Para tanto, basta que cada juiz tenha proferido seu voto com fundamento em um determinado argumento distinto e não apreciado pelos demais juízes integrantes da corte. Em uma tal hipótese, não se poderá dizer que o tribunal realmente criou nenhuma regra geral e abstrata, porque apesar da decisão coletiva e unânime, não existiu propriamente uma apreciação coletiva da corte sobre as questões de direito apresentadas por cada um de seus integrantes. Aliás, por isso é que em um real modelo precedentalista o julgador tem deveres ao estabelecer precedentes, dentre eles o de apreciar de maneira coletiva, para acolher ou rejeitar, todos os argumentos suscitados pelas partes e outros dos quais se tenha conhecimento, ainda que não trazidos pelas partes interessadas, para que se tenha parâmetros efetivos válidos de verificação do que realmente foi decidido pela corte coletivamente considerada (e não apenas por cada um de seus integrantes, o que é bem diverso) e, dessa forma, seja possível a detecção da ratio decidendi mesmo em casos complexos e de fundamentação múltipla. ${ }^{28}$

Dessa forma, conclui-se que para que o tribunal fixe uma ratio decidendi nos julgados que profere é preciso que a tese seja enfrentada pela corte coletivamente considerada, ao menos por sua maioria, não bastando sua apreciação por apenas um ou

\footnotetext{
${ }^{27}$ Embora cuidando de outro assunto (determinação dos fatos materiais/relevantes de um caso), e não propriamente na análise coletiva dos argumentos empregados por uma corte para julgar um dado caso, Arthur Lehman Goodhart afirma que, quando as opiniões dos relatores divergem na escolha dos fatos materiais mas convergem na conclusão obtida, somente os fatos tidos por materiais pela maioria dos juízes é que podem ser considerados como tal quando um juiz estiver analisando posteriormente esse precedente (The ratio decidendi of a case, p. 119).

28 "Muitas vezes, a corte vinculante consegue atingir uma maioria no que respeita ao resultado, à solução a ser conferida a determinado litígio, mas os magistrados divergem quanto às razões de justiça que embasam tal solução. Quando isso acontece e não é possível extrair um princípio comum a partir das opiniões da maioria, sua normatividade fica muito prejudicada. Será difícil definir o holding sem identificar os fins coletivamente aceitos para adotá-lo (...)" (Patrícia Perrone Campos Mello, Precedentes - o desenvolvimento judicial do direito no constitucionalismo contemporâneo, p. 200-201).
} 
alguns de seus integrantes. Enquanto tal não ocorrer, podem os demais tribunais seguir decidindo livremente a respeito do assunto, por não se poder falar em desobediência a nenhum precedente e até como forma de estimular as cortes superiores a realmente enfrentar de modo expresso as controvérsias e as discussões existentes a respeito delas.

\subsection{Métodos de identificação da ratio decidendi do precedente.}

Por conta das dificuldades existentes na tarefa de encontrar a ratio decidendi, os países adeptos do sistema da common law têm proposto e estudado métodos para encontrar o que em uma decisão é realmente é vinculante para os casos subsequentes, ou seja, têm buscado técnicas para identificar qual a ratio decidendi de um julgado precedente, uma vez que, como se sabe, a ratio decidendi é a parcela do julgado anterior que vincula os julgamentos posteriores. Existem, basicamente, dois métodos, o fático-concreto e o abstrato-normativo. ${ }^{29}$

No método fático-concreto, como a própria terminologia está a sugerir, o principal critério para encontrar a ratio decidendi de um julgado precedente são os fatos tidos por relevantes pelo julgador deste caso concreto anterior. $\mathrm{O}$ fundamental aqui é definir que fatos foram considerados importantes (fatos materiais) para o deslinde da causa precedente e quais não foram (fatos imateriais). A partir daí, em todos os casos posteriores em que tais fatos materiais estejam presentes, a solução jurídica terá de ser a mesma, estejam ou não presentes também os fatos laterais, tidos por irrelevantes ou indiferentes pela corte. Para o método fático-concreto, mais importante do que as considerações jurídicas feitas pelo próprio tribunal, são os fatos por ele levados em conta. A ratio decidendi aqui é estabelecida com base em dados concretos. Primeiro, o juiz do caso seguinte analisa todos os fatos submetidos ao caso precedente, verifica quais foram tidos por materiais e quais foram considerados imateriais. Em seguida, verifica a correspondência disso no próprio caso que presentemente tem de julgar e, a partir do resultado deste cotejo, verifica se está ou não submetido à ratio decidendi do julgado precedente. Se os fatos materiais/relevantes forem exatamente os mesmos, a ratio decidendi do precedente - obtida a partir dessa

${ }^{29}$ A terminologia é de Celso de Albuquerque Silva (Do efeito vinculante - sua legitimidade e aplicação, $\mathrm{p}$. 211). 
análise fático-concreta - terá de ser observada. ${ }^{30} \mathrm{Se}$, no caso presente, houver algum fato material/relevante diferente do caso precedente para mais ou para menos, não se poderá dizer que o caso posterior é igual ao caso anterior e em consequência o julgador de agora não estará obrigado a seguir a ratio decidendi do precedente.

Este é o método preferido daqueles que defendem uma atuação bem mais contida da função normativa das cortes, limitando-a quase que exclusivamente apenas à solução concreta e casuística de litígios, servindo os precedentes somente para situações fáticas rigorosamente idênticas, apenas para evitar tratamentos díspares e impedir a desigualdade em situações fáticas exatamente iguais. O tribunal, ao julgar o caso precedente, não cria propriamente uma regra jurídica. Apenas dá um deslinde a uma hipótese fática que, quando se repetir, a ela terá de ser dada a mesma solução nos julgados seguintes. A premissa é que à função judicante não compete o estabelecimento de princípios nem de soluções amplas, daí o apego às particularidades de ordem fática, para que só a casos verdadeiramente idênticos, isto é, aqueles em que estejam presentes todos os fatos materiais existentes no caso anterior, esteja o tribunal subsequente obrigado a dar a mesma solução anterior. $\mathrm{O}$ tribunal só deve criar o direito na exata medida do que for necessário para a solução do caso concreto que estiver sob sua apreciação. Quando precisamente este mesmo caso se repetir com exata semelhança fática, o julgador seguinte deve repetir a regra já existente fixada no caso precedente.

Uma das principais dificuldades do método fático-concreto é saber quais

\footnotetext{
${ }^{30}$ Um declarado seguidor do método fático-concreto é Arthur Lehman Goodhart. Em artigo de 1959, no qual ele esclarece pontos de um outro artigo que havia publicado em 1931 também a respeito da ratio decidendi, o autor diz que a ratio decidendi de um caso é obtida pela determinação (a) dos fatos considerados pelo juiz como materiais e (b) das decisões baseadas nestes fatos. Acrescenta que é nestes fatos que ele, o juiz, apontou como sendo materiais, relevantes, que o julgamento é baseado, e em nenhum outro mais. Por isso, analisar um caso precedente não seria apenas analisar os fatos e a conclusão do juiz no caso pretérito mas analisar os fatos que o juiz escolheu como materiais e, em seguida, apreciar as conclusões a que ele chegou baseado nestes fatos materiais. A regra de direito aplicada pelo juiz no caso pretérito seria relevante porque ela poderia fornecer diretrizes para determinar que fatos foram considerados materiais (relevantes) ou imateriais (irrelevantes), afirmação que demonstra uma preocupação primeiramente com os fatos e só depois com o direito, com a regra jurídica aplicada à hipótese.

Como exemplo, o autor invoca um julgado em que foi dito que "deve-se tomar um cuidado razoável para evitar ações ou omissões que previsivelmente podem causar danos a alguém” para depois dizer que não vislumbra nesta frase do julgado uma regra obrigatoriamente aplicável aos casos seguintes, o que não quer dizer que ela não seja importante, só que tal importância adviria de fornecer uma indicação para a determinação dos fatos escolhidos pela corte como materiais/relevantes, ou seja, a regra contida na frase só seria aplicável quando no caso seguinte se repetissem fatos semelhantes aos ocorridos no precedente em que ela foi proferida. Cf. The ratio decidendi of a case, p. 119-120.
} 
efetivamente foram os fatos tidos por materiais/relevantes no julgado anterior. Considerando a premissa existente neste método de que a fixação e a criação de regras pelos tribunais deve ser vista numa perspectiva restritiva, a solução para essa dificuldade de saber quais fatos devem ser considerados materiais/relevantes e quais não devem é dada pela afirmação de que, na dúvida, o fato foi sim considerado material e relevante no primeiro julgamento e, por isso, para que a solução precedente precise ser observada é preciso que o mesmo fato também tenha se repetido no julgamento do caso seguinte. Se isso não tiver acontecido, a observância do precedente não é obrigatória. Dessa forma, restringe-se as chances de o caso seguinte ser o mesmo da hipótese anterior e afasta-se do julgamento subsequente a obrigação de cumprir a decisão anterior, tudo nesta toada bem restritiva de estabelecimento da ratio decidendi. Uma outra forma de se reduzir o alcance da ratio decidendi do caso precedente ocorre quando o juiz do julgamento posterior considera como material/relevante um fato assim não considerado, ou não existente, no julgamento inicial. Desta forma, como as hipóteses fáticas já não serão materialmente as mesmas, a ratio decidendi do caso anterior não será aplicável, não existindo, portando, dever de obediência ao precedente.

Uma crítica dirigida ao método fático-concreto reside em ele conferir uma liberdade muito grande à corte vinculada. Basta que seja apontado como material um determinado fato não contido na ratio decidendi do precedente para que os casos sejam considerados distintos e não exista obrigação de respeito ao julgamento anterior. ${ }^{31}$ Além disso, para que se saiba quais são os fatos materiais/relevantes e os fatos materiais/irrelevantes é preciso que se analise as razões da decisão, porque será nelas que a corte deverá explicar porque dados fatos são importantes para o deslinde da causa e porque outros fatos não o são. Esta particularidade expõe uma outra falha do método fáticoconcreto, na medida em que o suposto purismo do método fático-concreto desaparece, já que a ratio decidendi não estará sendo buscada apenas na concretude dos fatos tal como

\footnotetext{
${ }^{31}$ A crítica de Celso de Albuquerque Silva é pungente: “(...) o método confere à corte vinculada uma grande liberdade na escolha dos fatos materiais do caso para o fito de averiguar se está ou não obrigada a seguir o princípio firmado no caso precedente. Como todo caso sempre é em algum aspecto diferente do caso precedente, isso permite que a corte vinculada escolha a seu arbítrio qualquer fato que não esteve presente no caso precedente para fins de distinção, decidindo contrariamente ao precedente. Essa absoluta liberdade conferida pelo método abre porta ao subjetivismo e arbitrariedade, derruindo o conceito de rule of law, que tem por objetivo principal a redução, se não a própria exclusão, da arbitrariedade humana no processamento do direito" (Do efeito vinculante - sua legitimidade e aplicação, p. 217).
} 
propugnada pelo método, mas também na fundamentação da decisão. ${ }^{32}$

O método abstrato-normativo, por sua vez, é mais amplo. A ratio decidendi é extraída não exclusivamente dos fatos, mas da solução jurídica dada pela corte, dos fundamentos (fáticos e jurídicos) que levaram à tal solução e de sua habilidade de ser repetida em casos parecidos, ainda que não faticamente iguais, mas desde que semelhantes. Há uma inegável similitude (embora não identidade) com a aplicação de uma lei, já que se vai buscar no precedente uma regra geral e abstrata nele existente e estabelecida a partir do caso originalmente julgado. Trata-se de retirar do precedente uma regra. Construída a partir de um caso concreto, mas ainda assim uma regra, com maior ou menor grau de abstração a depender do que tiver sido a decisão da corte. Obviamente, a prática não é a mesma que aplicar uma lei, justamente porque a regra, a ratio decidendi, terá vindo de uma controvérsia concreta, de um caso específico, o que pode dificultar a tarefa da corte que julgará o caso subsequente de saber o que efetivamente ela tem de obrigatoriamente obedecer, vale dizer, o julgador seguinte pode ter alguma dificuldade em encontrar qual foi a regra jurídica estabelecida pelo precedente que ele tem de cumprir. Seja como for, no método abstrato-normativo a ratio decidendi é uma regra geral, extraível de um julgamento precedente e passível de ser aplicada a casos futuros.

Para que o método abstrato-normativo funcione de uma maneira mais fluida, é preciso que o tribunal, ao perceber que está diante de um caso no qual poderá ser fixado uma ratio decidendi de cumprimento obrigatório por outras cortes, já profira a decisão do respectivo caso concreto fixando balizas mais nítidas e mais objetivas sobre a regra jurídica abstrata que está a estabelecer, isto é, sobre a ratio decidendi a ser observada nos julgamentos seguintes. Ou seja, o precedente não é fixado a esmo, como que uma consequência incidental. A corte sabe que está inserida em um modelo de cumprimento obrigatório de precedentes e, nessa condição, ao julgar um caso potencialmente suscetível de se tornar um precedente, assume conscientemente um papel de definidora de uma regra mais genérica e mais abstrata que transcenderá, de maneira prospectiva, o caso concreto específico sob julgamento. Ao proceder dessa forma, o tribunal lega para os julgamentos seguintes não apenas o precedente, a ratio decidendi em si, mas critérios mais facilmente

${ }^{32} \mathrm{O}$ próprio Arthur Lehman Goodhart assume essa necessidade de se ir aos fundamentos da decisão para descobrir quais foram os fatos considerados como materiais. Cf. The ratio decidendi of a case, p. 119. 
verificáveis para seu cumprimento. Essa consciência é muito importante, porque é muito pouco provável que o caso posterior seja rigorosamente igual, em todos os aspectos, ao caso anterior. Mesmo assim, é possível que a regra jurídica do caso anterior deva ser aplicada ao caso posterior, apesar de suas diferenças. É justamente para que se saiba com mais clareza se e quando o precedente deve ser observado não obstante as naturais e inevitáveis particularidades dos casos seguintes que esse estabelecimento assumido e consciente da generalidade da regra fixada no precedente e das formas para encontrá-la em muito contribuiu para um melhor e mais desenvolto funcionamento do sistema de precedentes.

Celso de Albuquerque Silva esclarece bem esse papel do tribunal ao dizer que “(...) como a corte da decisão de hoje que será a corte vinculante de amanhã sabe que os fatos que são hoje objeto de adjudicação raramente surgirão com plena identidade no futuro, ao decidir colimando vincular decisões futuras, pensará (e consequentemente assim agirá) que a decisão atual estabelecerá um precedente para uma série de fatos que contêm algum ponto de identidade com a série de fatos ora analisada" 33

Os seguidores do método abstrato-normativo preconizam que o tribunal retira do caso concreto uma regra jurídica abstrata a ser cumprida posteriormente por todos e obedecida nos casos subsequentes. A ratio decidendi é extraída da fundamentação fática e jurídica do julgamento precedente. O caso concreto no qual a ratio decidendi (a regra abstrata a ser obrigatoriamente observada nos casos seguintes) foi encontrada/estabelecida é apenas uma das hipóteses em que ela pode ser aplicada. A forma como o tribunal enfocou e caracterizou os fatos do caso concreto precedente, a importância dada a eles na aplicação da regra jurídica encontrada/estabelecida, também vai fazer parte da ratio decidendi, dando a ela maior ou menor extensão, maior ou menor generalidade. Como foi dito acima, no método abstrato-normativo a corte sabe que está a fixar um precedente e que ele contém não apenas a solução do caso concreto em que está sendo criado mas também uma regra genérica e abstrata que deverá ser observada por outros julgadores em casos seguintes. Por isso, cabe a ela deixar claro qual o grau de identidade e similitude que os fatos dos julgados posteriores precisam ter para poder sofrer a incidência do precedente. Vale dizer: a corte precisa ser o mais clara possível a respeito da ratio decidendi (porção do julgamento de ${ }^{33}$ Do efeito vinculante - sua legitimidade e aplicação, p. 214. 
observância obrigatória nos casos seguintes) que está a criar para os julgadores que lhe seguirão.

Esclareça-se que para o método abstrato-normativo os fatos são sim importantes, mas não exclusivamente, nem isoladamente. A regra abstrata em que se consubstancia a ratio decidendi decorre dos fatos em associação com as consequências jurídicas a eles aplicadas. Se o julgador houver por bem aplicar a regra geral que está estabelecendo no precedente somente a fatos bem específicos, tal é possível e deve restar bem esclarecido na decisão. Já se a ratio decidendi do precedente, apesar de estar surgindo em um caso concreto com determinadas particularidades fáticas, também puder se estender a outras situações diversas, mas de certo modo assemelhadas, isto também será possível, cabendo ao julgado deixar consignado os contornos dessa extensão que pode ser dada à regra geral e abstrata que está a decorrer da ratio decidendi.

Comparando os dois métodos, verifica-se que no método fático-concreto não existe a criação de uma regra jurídica abstrata e geral, porquanto a adstrição aos fatos materiais termina fazendo com que, na prática, apenas se garanta que se um caso faticamente idêntico voltar a ocorrer, não haverá soluções distintas. Já o método abstratonormativo permite que, mesmo para casos que não seja faticamente idênticos, a ratio decidendi do precedente incida, desde que neles se vislumbre a necessidade de aplicação de um regra jurídica comum.

Um exemplo pode ajudar a distinguir as duas técnicas para identificação da ratio decidendi. Em um determinado caso, o Ministério Público pleiteou em favor de um único indivíduo o fornecimento de dado medicamento. Com base no art. 127, caput, da Constituição da República de 1988, o Superior Tribunal de Justiça (STJ), ao apreciar a questão sobre a existência ou não de legitimidade do Ministério Público para o ajuizamento de ações em defesa do direito de apenas um indivíduo, decidiu que ao Ministério Público incumbe a defesa de direitos individuais quando eles forem indisponíveis e que o direito à saúde, por força do art. 196 da Carta Magna de 1988, inserese no rol daqueles direitos indisponíveis, razão pela qual sua tutela jurisdicional pode ser buscada pelo Ministério Público, ainda quando feita em favor de pessoa determinada. ${ }^{34} \mathrm{~A}$

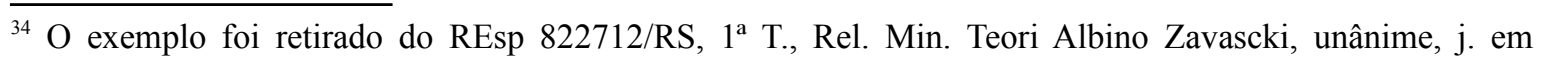


análise do julgado mostra que foram relevantes para a corte (a) a existência de um dispositivo constitucional dando ao Ministério Público a obrigação de agir em defesa de direitos individuais indisponíveis, (b) existirem direitos que, por sua natureza indisponível, convém sejam defendidos em juízo pelo Ministério Público, ainda quando em favor de apenas uma pessoa e (c) ser o direito à saúde um direito indisponível.

Acaso fosse empregado o método fático-concreto, os demais tribunais só precisariam obedecer ao que foi decidido no julgamento mencionado se e quando se estivesse diante de hipótese na qual o Ministério Público postulasse em favor de uma só pessoa o fornecimento de medicamento. Se o pleito fosse outro, ainda que ligado à saúde, não haveria vinculação, já que a ratio decidendi do precedente diria respeito apenas ao fornecimento de medicamento. A corte do caso seguinte até poderia aplicar o mesmo entendimento do julgamento precedente, mas a tanto não estaria obrigada, porque as hipóteses fáticas seriam distintas. Por outro lado, aplicando-se o método abstratonormativo, sempre que se estivesse diante de ação objetivando proteger o direito indisponível à saúde, os julgadores teriam de reconhecer a legitimidade ativa do Ministério Público em atenção à ratio decidendi do precedente. Na casuística, verifica-se que o método seguido na prática brasileira, consciente ou inconscientemente, é o abstratonormativo. Por isso é que a legitimidade ativa do Ministério Público para pleitear direitos em favor de apenas uma pessoa vem sendo reconhecida sempre que se cuida de direito à saúde, mesmo que não se cuide exatamente de fornecimento de medicamentos. ${ }^{35}$

A hipótese exemplificativa trazida acima mostra que um mesmo caso pode servir ou não de precedente vinculante a depender da abrangência que se lhe dê. Alguém poderia

4/4/2006, pub. DJ 17/4/2006, p. 196.

${ }^{35}$ Podem ser citados, somente no STJ, os seguintes exemplos: fornecimento de lentes corretivas enquanto o paciente aguarda transplante de córnea (REsp 850813/RS, $2^{\mathrm{a}}$ T., Rel. Min. Humberto Martins, unânime, j. em 15/8/2006, pub. DJ 5/9/2006, p. 234), disponibilização de alimento especial indispensável à saúde, cuja ausência poderia ocasionar a morte prematura (REsp 823079/RS, 1ª T., Rel. Min. José Delgado, unânime, j. em 17/8/2006, pub. DJ 2/10/2006, p. 236), realização de cirurgia (REsp 741369/RS, $2^{\mathrm{a}}$ T., Rel. Min. Humberto Martins, unânime, j. em 22/8/2006, pub. DJ 1\%/9/2006, p. 246), prestação de tratamento fonoaudiológico (AgRg no REsp 752190/RS, $1^{\text {a }}$ T., Rel. Min. Luiz Fux, unânime, j. em 10/10/2006, pub. DJ 13/11/2006, p. 231), realização de parto em hospital que disponha de unidade de terapia intensiva neonatal (REsp 865901/RS, $1^{\text {a }}$ T, Rel. Min. Teori Albino Zavascki, unânime, j. em 5/12/2006, pub. DJ 14/12/2006, p. 316) e realização de tratamento médico consistente em internação hospitalar seguida de posterior realização de cirurgia (REsp 695396/RS, $1^{\text {a }}$ T., Rel. Min. Arnaldo Esteves Lima, unânime, j. em 12/4/2011, pub. DJE 27/4/2011). Em todos esses casos o STJ reconheceu a legitimidade ativa do Ministério Público para defesa em juízo do direito indisponível à saúde, mesmo com o pleito sendo feito em favor de apenas um indivíduo. 
entender que o Ministério Público só tem legitimidade para pleitos em favor de indivíduos isolados quando se tratar (a) de medicamentos excepcionais, (b) de qualquer medicamento, (c) de medicamentos e cirurgias ou (d) de qualquer providência ligada à defesa do direito à saúde. Vê-se que uma mesma situação fática pode gerar precedentes com abrangência e generalidade de diversos graus e amplitudes. Na casuística, o STJ optou pelo entendimento mais abrangente e mais genérico, talvez até para prestigiar o tipo de direito material cuja tutela se buscava (direito à saúde), mas o fato é que o precedente poderia ter sido fixado em patamares mais restritos de concessão da legitimidade. E essa abrangência ou restrição é retirada das considerações feitas pela corte quando julgou o leading case estabelecedor do precedente.

Da análise das principais características dos dois métodos existentes para fins de verificação da ratio decidendi de um precedente, observa-se que, mais importante do que a adoção de um ou de outro ou a crítica a qualquer um deles, é a constatação de que ambos, cada um deles a seu modo, dá um importante contributo à teoria dos precedentes, um realçando a importância dos fatos subjacentes à decisão, o outro dos fundamentos desta decisão. Apesar disso, o método abstrato-normativo aparenta ser o melhor, ou o menos imperfeito, na detecção da ratio decidendi de um caso, na medida em que se preocupa com todos os componentes da decisão precedente, isto é, tanto seu substrato fático quanto jurídico.

\subsection{A extensão da ratio decidendi.}

Além da questão referente à identificação da ratio decidendi propriamente dita, ou seja, de verificar o que especificamente em um caso anterior será vinculante para os casos posteriores, uma outra questão relevante diz respeito à delimitação da extensão da ratio decidendi, isto é, sua abertura ou generalidade. Se a ratio decidendi é a regra geral que advém de um precedente e que será aplicável a todos os casos futuros assemelhados, ainda que não idênticos, surge a problemática consistente em saber até onde vai a regra geral, isto é, qual seu tamanho, abertura, extensão, amplitude. Dito de outra forma, saber que situações fáticas ou jurídicas estão por ela abrangidas e por isso demandam dos julgadores dos casos seguintes o cumprimento e a obediência da ratio decidendi. 
Como visto anteriormente, no método fático-concreto, muito mais apegado às particularidades de ordem fática, não se pode falar propriamente na criação de uma regra geral e abstrata mas sim na repetição de soluções jurídicas quando hipóteses fáticas se repetem. Por conta disso, aqui o problema referente à abertura, amplitude ou generalidade da ratio decidendi é menor porque a ratio decidendi é de ordem quase que exclusivamente objetiva, ligada concretamente aos fatos. Tudo o que se tem a fazer é verificar a existência ou não de correspondência fática tendo por parâmetros os fatos materiais/relevantes. Se houver correspondência, a solução deve ser a mesma. Do contrário, não.

Contudo, a adoção do método abstrato-normativo como técnica para identificar a ratio decidendi de um caso, isto é, a porção vinculante do precedente, implica o reconhecimento da existência, no precedente, de uma regra geral e abstrata que se desprende do caso concreto em que foi estabelecida e passa a vincular casos futuros. Conforme se disse, o problema consiste agora não mais em determinar a existência de uma regra, mas sua extensão, sua abertura. Uma coisa é dizer que a ratio decidendi é uma regra. Outra é afirmar a extensão desta regra.

Já se disse que a regra consistente na ratio decidendi é extraível da análise da demanda em apreciação, dos fatos importantes para o deslinde dado a ela, da fundamentação e da decisão em si. No entanto, a depender de como esse conjunto de circunstâncias foi posto na decisão, o resultado pode indicar uma regra mais ou menos aberta, mais ou menos extensa e, portanto, aplicável a um maior ou menor número de casos. A análise dessa maior ou menor extensão, abertura, tamanho ou generalidade da ratio decidendi é importante para que não exista uma manipulação do precedente a fim de torná-lo, por conveniências, mais ou menos amplo, em desvirtuamento, ainda que parcialmente, daquilo que originalmente era a regra fixada na ratio decidendi.

Patrícia Perrone Campos Mello foi precisa quando disse que

“A elaboração de critérios para a determinação da amplitude da regra é, portanto, essencial para a preservação da norma produzida judicialmente, em especial se considerado que são 
as cortes vinculadas aquelas que primeiro interpretarão um precedente, ao serem chamadas para decidir um novo caso alegadamente análogo. Trata-se de medida necessária a limitar a possibilidade de manipulação do julgado, cujo teor poderia ser invocado em termos mais amplos ou mais restritos, conforme o interesse que se desejasse favorecer, circunstância inevitável, mas que o stare decisis busca mitigar". ${ }^{36}$

O stare decisis assumidamente busca reduzir o componente argumentativo, valorativo e ideológico relativamente àquilo que já foi decidido. Não se nega que isso reduz a liberdade individual do julgador do caso seguinte, o qual vai precisar de muitos argumentos de fato e de direito acaso queira se afastar, alterar ou de alguma forma contornar o precedente. Mesmo assim, os elementos de ordem subjetiva não estão completamente afastados em um modelo precedentalista, já que a regra geral advinda do precedente, até por não ser enunciada textualmente como na lei, sempre permitirá alguma abertura para interpretações, valorações e influências.

Por isso, na definição da maior ou menor abertura da ratio decidendi, é preciso que se lance mão de critérios os mais objetivos possíveis, justamente para evitar a alegação de que a ampliação ou a restrição do alcance da regra retirada do precedente foi feita pelo julgador do caso seguinte por razões reprováveis ou escusas.

Com essa finalidade, um primeiro elemento que pode contribuir para que se perceba, com um maior grau de objetividade, qual é a extensão ou generalidade da ratio decidendi é a própria linguagem usada para se referir aos fatos ou às questões jurídicas discutidas no caso. As expressões e a terminologia usadas para se referir à problemática fática ou jurídica pode ter sido mais ou menos ampliativa e, a depender disso, os julgadores dos casos seguintes estarão ou não autorizados a interpretar a regra emanada do precedente de uma maneira mais ampla. Por exemplo, o conceito de "família" é mais aberto que o de "pais" ou "irmãos". Falar em "direito à saúde" é dizer muito mais que apenas "direito à cura", porque também abrange a prevenção às doenças. Nesse contexto, se, em um pleito formulado por uma dada categoria de empregados a respeito de um determinado benefício, o tribunal reconhece que o direito postulado é devido a todos os empregados de uma

${ }^{36}$ Precedentes - o desenvolvimento judicial do direito no constitucionalismo contemporâneo, p. 131. 
maneira geral e, como tal, não pode ser negado à categoria que promoveu a ação, não estará destoando de um precedente dessa forma fixado uma corte que, apreciando um caso posterior com pedido formulado por uma categoria de empregados completamente diferente, ainda assim lhe conceder o benefício. É que no caso anterior a linguagem usada pela corte - empregados - é genérica, ampla, autorizando sua extensão a todos os que forem empregados, independentemente da categoria profissional.

Um outro ponto que pode ser observado para delimitar a abrangência da regra geral emanada do precedente é o contexto em que estão inseridos os casos anterior e posterior. Em um dado contexto, estender a ratio decidendi de um julgado para carros, navios e aviões pode ser legítimo, já que todos são veículos. Por exemplo, uma regra precedente que determine a obrigação de navios terem uma identificação e um responsável pode ser estendida para um caso posterior que diga respeito a aviões, já que razões de segurança e de responsabilidade civil o recomendam. Já um precedente que concedeu uma isenção tributária para a fabricação de aviões no Brasil interpretando uma lei de incentivo ao transporte aéreo no país não pode ser invocado em um caso posterior em que se pleiteie a isenção para carros.

$\mathrm{O}$ estudo dos casos anteriores e posteriores à fixação do precedente igualmente pode ajudar na delimitação de sua extensão. Imagine-se um julgado proferido em 2011 no qual a regra estabelecida tenha sido amplamente permissiva da possibilidade do reconhecimento legal da união estável entre pessoas do mesmo sexo, em rompimento com o entendimento anterior, que era a negação dessa possibilidade. Constatado que o precedente foi cunhado em um caso que representou uma mudança completa de entendimento relativamente ao passado, qualquer tentativa de aplicação da regra proveniente deste precedente de modo a restringi-lo e a retornar, ainda que parcial ou indiretamente, ao entendimento anterior a 2011 e agora ultrapassado, representará uma restrição indevida da regra contida na ratio decidendi do precedente.

Também a análise dos casos seguintes ao estabelecimento do precedente pode ajudar na definição da extensão da ratio decidendi do precedente. Se a regra geral tiver sido cunhada de modo excessivamente amplo ou demasiadamente reduzido, deixando 
dentro hipóteses que deveriam estar excluídas ou fora situações que deveriam estar cobertas, os casos seguintes podem temperá-la até que se encontre seu equilíbrio. Note-se que não se trata de uma burla ao precedente, que deveria ser seguido e pronto. Tampouco isso é distinção (distinguishing) ou superação (overruling) do precedente. O que se tem é mero ajuste, feito justamente para que a verdadeira regra vinda do precedente possa ser cumprida em sua essência.

As particularidades do caso concreto também são uma forma de se verificar a correta extensão da ratio decidendi do precedente. Se o julgado foi muito enfático ao discorrer sobre os pormenores de ordem fática, realçando com destaque as especialidades do caso, provavelmente tem-se aí um precedente de pequeno alcance, justamente porque não só a solução dada ao caso concreto mas também a própria regra geral foi extremamente casuística.

A depender da importância das particularidades do caso concreto para a solução dada pelo julgador pode-se até dizer que houve um "não-precedente", uma solução do caso concreto que, de tão restrita e específica, não chega sequer a configurar uma ratio decidendi, entendida esta como uma regra geral, podendo-se falar apenas em solução do caso pura e simplesmente, sem o surgimento de nada geral nem abstrato. A rigor, não existe qualquer problema na opção, feita pela corte vinculante, de não fixar o precedente em um caso cheio de especificidades. A única consequência é que os jurisdicionados e os demais julgadores vão permanecer sem uma ratio decidendi a respeito de um dado tema mas isso em muitos casos é tecnicamente melhor do que o surgimento de um precedente a partir de um caso tão particular que inviabiliza sua aplicação nos casos seguintes ou que é logo em seguida modificado quando surge um caso mais apropriado para o estabelecimento de uma regra mais geral e mais abstrata.

Um problema maior e mais grave surge quando são os julgadores vinculados, os quais deveriam cumprir o precedente, que começam a não fazê-lo em decorrência ou a pretexto da (suposta) presença de particularidades do caso concreto. É preciso muita atenção e cuidado com esta prática, para que não se termine fugindo do modelo precedentalista. Uma coisa é a calibragem da extensão da regra geral por meio da inclusão, 
nela, de situações semelhantes que aparentemente estava excluídas ou da exclusão de hipóteses distintas mas que em princípio estariam abrangidas. Esse ajuste, como foi mencionado acima, é lícito e até necessário. Outra coisa bem diferente é valer-se de pormenores de ordem fática - que de resto todo caso sempre vai apresentar - como indevido subterfúgio para negar vinculação ao precedente ou para dizer que ele não se aplica ao caso presente. Em situações tais, o dever de argumentação da corte vinculada que deveria seguir o precedente no caso posterior é muito mais intenso, tendo ela o dever de mostrar, de maneira especialmente fundamentada, quais são efetivamente as particularidades do caso concreto e porque elas impedem a incidência da ratio decidendi do precedente.

Uma outra forma de determinar o alcance de uma ratio decidendi é analisar quais foram os fins buscados pela decisão que estabeleceu o precedente, o que pode acontecer de modo mais ou menos expresso ou assumido. Se, em um caso anterior é possível se vislumbrar que a corte pretendia um dado fim específico, nos casos posteriores a ratio decidendi do precedente deve ser buscada sempre de modo a prestigiar a consecução de tal fim. Por exemplo, se o Supremo Tribunal Federal, depois de longas discussões, profere uma decisão que restringe a participação no processo eleitoral de candidatos em cuja vida pública pregressa se vislumbre a prática de fatos que contrariem a probidade e a moralidade administrativa, verifica-se que a finalidade de uma decisão com este conteúdo foi enfatizar a probidade e a moralidade administrativa. Dessa forma, no futuro, se e quando as cortes vinculadas a este precedente precisarem de um parâmetro para definir o maior ou o menor alcance da regra geral dele proveniente, deverão interpretar a ratio decidendi de um modo que busque e consagre o fim pretendido pelo tribunal ao julgar o precedente, isto é, deverão buscar o entendimento que mais prestigie a moralidade e a probidade administrativa.

A análise da extensão objetiva da ratio decidendi dá mais uma demonstração de que para um funcionamento mais adequado de um modelo precedentalista o papel da corte que estabelece o precedente é relevantíssimo. Para que sejam reduzidas as chances de desvirtuamento ou manipulação do que realmente foi a ratio decidendi estabelecida no precedente, o tribunal deve deixar o mais claro possível se a regra geral que está a fixar é 
mais ou menos aberta, para que seja o mais fiel intérprete da regra que ele próprio criou.

\subsection{A mutabilidade posterior da ratio decidendi.}

Neste capítulo já se discutiu sobre o que é ratio decidendi, sobre os métodos existentes para encontrá-la no corpo de um julgado e sobre sua extensão ou generalidade em relação às situações de fato e de direito que abarca. Acerca deste último ponto, mostrou-se que existem alguns critérios que podem auxiliar na determinação o mais objetiva possível a respeito de ter a ratio decidendi uma maior ou menor abertura, tendo sido realçado que a definição, sob parâmetros legítimos, da maior ou menor extensão, abertura, tamanho ou generalidade da ratio decidendi é importante para impedir que o precedente venha a ser manipulado e indevidamente tido por mais ou menos amplo, a depender da vontade de quem o aplica.

Dentre esses critérios, falou-se que a própria linguagem empregada no julgado precedente para se referir aos fatos ou às questões jurídicas discutidas no caso, se mais ou menos aberta, já é um indicativo de ser a ratio decidendi mais ou menos abrangente ("família" é mais aberto que "irmãos"). Outro parâmetro a ser utilizado é a análise do contexto fático ou jurídico em que inserido o caso anterior e posterior, porque a aplicação de um tratamento mais abrangente em um dado contexto pode não ser correta em outro (uma isenção tributária para a fabricação de aviões no Brasil não deve ser estendida para carros, embora ambos sejam veículos). A análise dos casos anteriores e posteriores à fixação do precedente também é um dos critérios para determinação da extensão fática e jurídica da ratio decidendi, porque se o estudo dos casos anteriores indica que o precedente rompeu com o que vinha sido entendido até então, qualquer tentativa de retorno será indevida. Além disso, se a análise dos casos posteriores mostrar que o precedente foi fixado de modo bastante amplo ou muito reduzido, abrangendo indevidamente algumas situações ou injustificadamente deixando outras de fora, ajustes podem ser feitos em busca do equilíbrio.

Também a análise dos casos seguintes ao estabelecimento do precedente pode ajudar na definição da extensão da ratio decidendi do precedente. Se a regra geral tiver 
sido cunhada de modo excessivamente amplo ou demasiadamente reduzido, deixando dentro hipóteses que deveriam estar excluídas ou fora situações que deveriam estar cobertas, os casos seguintes podem validamente temperá-la até que se encontre a justa proporção.

É precisamente sobre a atuação e a interferência dos casos seguintes nos precedentes que se cuidará agora.

O precedente, por meio da ratio decidendi, estipula a partir de um caso concreto uma regra geral e abstrata passível de ser aplicada aos casos seguintes. Em um primeiro momento, a regra jurídica aplicada pelo juiz do caso anterior pode e deve ser repetida nos casos seguintes semelhantes. No entanto, por conta da riqueza fática proveniente da experiência cotidiana e da própria evolução da vida em sociedade, nem sempre a regra geral egressa do precedente será a melhor. Por diversas razões, a regra geral originária pode ter incluído ou excluído hipóteses fáticas e/ou jurídicas de maneira indevida, ou imprecisa, para mais ou para menos. Para essas situações, é preciso que o sistema tenha alguma flexibilidade, alguma válvula de escape, contemplando formas de calibragem para que possa seguir atendendo aos valores que justificam sua existência.

O problema é que, se o modelo de precedentes existe (também) para dar isonomia e segurança, previsibilidade e estabilidade jurídicas, pode-se questionar qual a validade e a serventia da ratio decidendi do caso anterior como regra a balizar os casos seguintes se ela puder ser alterada nos casos posteriores, a depender de suas particularidades.

A análise de uma hipótese do cotidiano talvez ajude a uma melhor compreensão do problema.

Atualmente, é sabido que, em decorrência de normas internacionais de segurança aeroportuária, não se permite o ingresso em aeronaves com uma quantidade de líquido superior a $100 \mathrm{ml}$, seja de que natureza for. Se alguém quiser, por exemplo, embarcar com uma garrafa de água com quantidade superior à quantidade de $100 \mathrm{ml}$, terá o seu ingresso obstado. $\mathrm{O}$ acesso ao saguão de embarque que dá acesso às aeronaves está necessariamente 
condicionado ao passageiro se desfazer da referida garrafa de água. Acaso alguém precise de água, depois de submetido aos controles de segurança, existem locais nos quais são vendidas garrafas de água que, por terem sido previamente fiscalizadas, podem ser levadas a bordo. Essa regra é determinada por questões de segurança, para impedir que se levem a bordo líquidos que possam envenenar ou entorpecer a tripulação ou que de alguma outra forma possam ser empregados para fins terroristas (confecção de explosivos a partir de misturas, por exemplo).

Imagine-se agora a situação de um pai que pretende embarcar com sua filha de apenas alguns poucos meses, que naturalmente se alimenta exclusivamente de comidas líquidas ou pastosas, em um vôo longo, para um destino distante. Com a incidência da regra, o pai não poderá embarcar com os recipientes contendo os alimentos de sua filha, naquilo que excederem $100 \mathrm{ml}$. Não obstante, por maiores e mais importantes que sejam as razões de segurança, não aparenta ser correto nem razoável proibir que este pai, nestas circunstâncias, embarque com mais de $100 \mathrm{ml}$ de líquidos, desde que o excesso represente apenas aquilo que for destinado à alimentação de sua filha, sob pena de isso acarretar a ausência de alimentação da filha ou a impossibilidade de ela fazer uso de transporte aéreo, além de não estar presente nenhuma ameaça sequer indireta aos motivos que levaram à edição da regra.

A questão, então, é saber o que deve prevalecer, se razões ligadas à justiça material do caso concreto, o que levaria ao afastamento da regra e à permissão a que o pai ingresse no vôo com mais de $100 \mathrm{ml}$ de líquidos, ou se, diversamente, razões ligadas à segurança jurídica e à previsibilidade devem fazer prevalecer a regra existente, conquanto a situação seja bastante diferente daquela que levou a edição da regra.

Feita a transposição da regra existente neste exemplo para a teoria dos precedentes, torna-se importante conhecer a noção de formal reasons e de substantive reasons, expressões mais comumente usadas nos países de common law. As formal reasons são as disposições que se aplicam objetivamente, apenas porque o ordenamento determina imperativamente que elas sejam aplicadas. Já as substantive reasons são as razões de ordem subjetiva que justificam determinada solução. Emmanuel Q. Fernando explica que 
as formal reasons são aquelas facilmente identificáveis e que propiciam suficiente clareza para que se decida de acordo com elas. São três as características das formal reasons: (a) que ela seja uma regra; (b) que essa regra possa ser "mecanicamente" identificada sem necessidade de valorações subjetivas e (c) que essa regra seja "mecanicamente" aplicada. Nenhuma controvérsia deve existir nem nenhuma valoração é necessária. Tudo o que deve ser feito é a identificação da regra e a determinação se os casos estão ou não nela enquadrados.

Já as substantive reasons são baseadas na moral, na economia, na política, ou em razões institucionais ou sociais. São princípios ou políticas que envolvem interpretações controversas e o uso de juízo valorativo, aplicando-se existam ou não regras a respeito do assunto. Quando existem regras sobre o tema, as substantive reasons realçam os valores ou intenções por trás da regra.

As formal reasons se diferenciam das substantive reasons em quatro critérios: (1) níveis de generalidade; (2) graus de precisão; (3) graus de imposição e (4) capacidade de se autojustificar. As formal reasons são pouco genéricas, bastante precisas, direcionam a solução do caso (em vez de apenas recomendá-la) e não são autojustificáveis. Já as substantive reasons são bem genéricas, imprecisas, meramente recomendativas do deslinde do caso e autojustificáveis. São essas diferenças ou características que explicam as razões pelas quais as substantive reasons precisam de juízos de valor e por que elas servem como orientação para a construção das regras. ${ }^{37}$

37 'The prototype of a formal reason is an authoritative legal rule: the existence of a readily identifiable rule
directly covering a case and providing sufficient ground for rendering a decision in accordance with it. Three
requirements are involved: (i) that the formal reason is a rule; (ii) that such rule can be 'mechanically'
identified by means of some source-based test; and (iii) that such rule is 'mechanically' applied. No
controversial interpretation is possible and no value judgment necessary. All that is required is the purely
mechanical skill of identifying the rule and determining whether the facts of the case are logically subsumed
under the rule for the decision to be made.
On the other hand, substantive reasons are based on moral, economic, political, institutional or other social
considerations. They will be classified into two main types: principles and policies. They are not necessarily
derived from authoritative legal sources and applying them involves controversial interpretation and the use
of value judgment. Moreover, they are applied whether or not a rule directly covering the case already exists.
In these instances, they provide the underlying value or purpose behind the rule, or an independent reason for
deciding in accordance with it, or an argument for a contrary result. (...)
Rules are to be distinguished from substantive reasons in terms of four characteristics: (i) levels of generality;
(ii) degrees of precision; (iii) degrees of directiveness; and (iv) ability to self-justify. Rules possess a low
level of generality, a high degree of precision, a high degree of directiveness (i.e., dictating rather than merely
guiding or influencing the result), and are not self-justifying. Substantive reasons, on the other hand, possess
a high level of generality, a low degree of precision, a low degree of directiveness, and are self-justifying.
These logical distinctions between rules and substantive reasons explain not only why the latter, and not the 
Constata-se, portanto, que as substantive reasons são baseadas em juízos de valor, em fundamentos de ordem subjetiva, ao passo em que as formal reasons são eminentemente objetivas, consistem basicamente na aplicação de regras claras já existentes. No exemplo ilustrativo trazido, ao se invocar o argumento de que o pai estava levando uma quantidade de líquido superior à permitida para poder alimentar sua filha em um vôo longo como justificativa para o afastamento da regra objetiva que proíbe qualquer quantia de qualquer líquido acima de $100 \mathrm{ml}$ o que se está fazendo é a invocação de substantive reasons para afastar as formal reasons. Alguém poderia dizer que não é justo, nem correto, tampouco ameaça a segurança aeroportuária, proibir-se que um pai leve comida líquida ou pastosa para alimentar sua filha em um vôo, ainda que a quantidade seja superior a $100 \mathrm{ml}$.

A dúvida persiste: para o Direito, o que é melhor, a obediência objetiva às regras, garantidora de segurança jurídica e previsibilidade, ainda que eventual causadora de injustiça, ou a permissão para que sejam introduzidas considerações subjetivas, que podem ser decisivas para a realização de justiça no caso concreto mas também para a redução do ambiente de segurança e de previsibilidade, em razão da possibilidade de afastamento casuístico das regras? Tratando-se de precedentes, o que é melhor, segui-los pura e simplesmente, com as vantagens decorrentes do modelo mas com o risco do cometimento de injustiças materiais em dados casos, ou ser flexível na aceitação do afastamento dos precedentes, consagrando a justiça casuística ainda que desnaturando um modelo calcado em previsibilidade?

Essas questões, em essência, representam a faceta de um dilema comum ao Direito, que é a contraposição entre segurança e justiça. A obediência firme e rigorosa aos precedentes em todos os casos assemelhados, inclusive aqueles com pormenores que poderiam levar a uma solução distinta, gera segurança. Bem ou mal, certa ou errada, sabese que a regra é aquela e que ela será obedecida. Já a aceitação de uma maior flexibilidade na obrigação de seguir precedentes afasta o componente segurança, porque já não se saberá

former, necessitate the use of value-judgment in interpretation but also why the latter's content may be further articulated by rules. In being more general, less precise and self-justifying, substantive reasons serve as the guiding rationale for the construction of rules. (...)" (The role and logic of substantive reasons adjudication, p. 56-57). 
mais com certeza qual será o resultado do caso, mas permite uma maior justiça material, reduzindo as hipóteses de decisões que poderiam gerar injustiça ou perplexidade.

A solução está em uma visão intermediária das coisas. Não há motivos para ser maniqueísta, nem peremptório. Embora o modelo precedentalista almeje, abertamente, para conseguir os valores que the caracterizam, ser predominantemente permeado por regras objetivas e por isso a opção primeira deva ser a repetição da regra contida no precedente aos casos similares (formal reasons), isso só acontece na medida daquilo que é possível. Por mais que se busque a redução da influência do subjetivismo, não existe sistema absolutamente puro e, dessa forma, sempre haverá abertura para que fatores de ordem subjetiva interfiram no resultado do julgamento (substantive reasons). A busca, então, tem de ser para que essa abertura para algum subjetivismo aconteça de um modo legítimo, não voluntarista, e que não frustre a sistemática do modelo precedentalista.

Assim, nos casos em que uma das partes pretenda a aplicação ou a recusa da regra estabelecida no precedente por razões que precisem de algum subjetivismo ("não é justo", “é desproporcional" ou "a finalidade por trás do precedente não é essa", por exemplo), caberá ao julgador verificar se deve prevalecer a regra geral do sistema precedentalista, que é a incidência das formal reasons por meio da aplicação do precedente ao caso, ou se, ao contrário, existem substantive reasons com idoneidade suficiente para justificar um tratamento diferenciado.

No exemplo anterior da segurança aeroportuária, alguém poderia pretender embarcar com uma garrafa de água em quantidade superior a 100ml argumentando para tanto que, se não o fizer, terá de adquirir água nos locais de venda posicionados depois dos controles de segurança, nos quais, embora sejam vendidas garrafas de água que, por terem sido previamente fiscalizadas, podem ser levadas a bordo, apresentam um preço demasiadamente elevado.

Para o julgador que se deparasse com as duas situações, a do pai e a da pessoa que pretendia fazer uma economia, poderia parecer injustificado o afastamento da regra geral proibitiva para aquele que queria poupar dada quantia mas, ao mesmo tempo, mostrar-se 
inteiramente legítimo o afastamento para o pai que apenas queria alimentar sua filha.

Na verdade, quem atribui a um dado julgado o caráter de precedente é o órgão jurisdicional que, apreciando o caso posterior, o aplica. Nessa perspectiva, portanto, o precedente só surge quando assim reconhecido como tal pelo julgador do caso seguinte. Por isso é que se diz que a regra geral extraída do precedente está sempre sendo (re)definida pelas interpretações daquelas autoridades a cargo das decisões dos casos seguintes, que podem ampliá-la ou restringi-la.

Assim, vê-se que, por mais que se permita a incidência de fatores subjetivos nos julgamentos de matérias a respeito das quais já existem precedentes, o emprego destes para afastar-se da regra geral (que é a obediência ao precedente) é de ser exercido com parcimônia, responsabilidade e de modo absolutamente justificado, para que o modelo precedentalista tenha nos fatores subjetivos uma forma de aperfeiçoamento (por meio da redução de situações injustas) e não de eventual burla ou desvio. Aliás, bem vistas as coisas, a permissão para que o modelo precedentalista seja permeado e arejado com argumentos de ordem subjetiva e de relativa indefinição (substantive reasons), desde que exercida corretamente, representa mais uma qualidade do sistema do que um seu enfraquecimento. $^{38} \mathrm{E}$ a possibilidade de recurso para a corte autora do precedente representa uma garantia contra possíveis equívocos na expansão ou na retração indevida do precedente, naquilo que será uma espécie de interpretação autêntica da corte a respeito de seu próprio precedente, servindo como desestímulos a abusos e desvios.

\subsection{Expansão dos precedentes.}

\subsubsection{Involuntária/inconsciente.}

A ratio decidendi (regra jurídica usada para solucionar um caso anterior) do precedente pode se expandir de maneira assumida e consciente e de modo involuntário e inconsciente. A expansão involuntária acontece quando o precedente é aplicado sem

\footnotetext{
${ }^{38}$ Patrícia Perrone Campos Mello, inclusive, resume que "paradoxalmente, o stare decisis é um mecanismo de estabilização e, ao mesmo tempo, de modificação do direito (Precedentes - o desenvolvimento judicial do direito no constitucionalismo contemporâneo, p. 187).
} 
maiores questionamentos, incidindo em caso posterior que o julgador vinculado enquadrou sem maiores problemas na hipótese do caso anterior. Diz-se que aí há expansão porque mesmo sem ter havido criação nenhuma, existiu a confirmação do precedente, isto é, sua ratificação, o reconhecimento pelo órgão jurisdicional de que estava vinculado a um julgado anterior. Além disso, como dois casos nunca são rigorosamente idênticos relativamente a seus fatos subjacentes, o julgamento seguinte sempre acrescenta algo mais no cenário fático abrangido pelo precedente.

\subsubsection{Voluntária.}

Quando um juiz ou uma corte vai julgar o primeiro caso a respeito de determinado assunto, chama-se tal caso de case of first impression ou de leading case, por não haver precedente ao qual o juiz ou a corte esteja vinculado. Uma das formas conscientes e voluntárias de se expandir um precedente é levá-lo em consideração quando da fixação de um novo precedente para o leading case, ainda que o precedente, nesta hipótese, não diga respeito exatamente ao mesmo assunto, embora em alguma medida forma conexo. É possível que, apesar de determinado tema estar sendo apreciado pelo julgador pela primeira vez, existam precedentes a respeito de assuntos relacionados com a matéria nova, embora com diferenças. Tais julgados, apesar de não serem de cumprimento obrigatório (justamente por não dizerem respeito a fatos semelhantes, daí se tratar de um case of first impression), podem ser considerados pelo tribunal porque cabe a ele, ao julgar o leading case, observar o estado atual dos precedentes ligados com o tema que tem de decidir, para que não seja apresentada uma decisão divorciada ou incoerente com a linha de entendimento que até então se vinha seguindo na corte a respeito do assunto. Vale dizer, embora o julgado a ser proferido possa ser livre precisamente porque trata de matéria nova, ou seja, conquanto não deva ele observância vinculante a nenhum precedente, também não pode simplesmente romper com os precedentes já existentes a respeito de regras jurídicas conexas, embora com diferenças.

Imagine-se que um homem casado e de boa situação patrimonial tem, ao mesmo tempo e durante décadas, duas amantes, convivendo com as três com relativa naturalidade, apenas com o cuidado para não ser descoberto pela esposa nem pelos filhos. A esposa 
nunca soube de nada a respeito das amantes mas estas sempre tiveram conhecimento de que o homem era casado e também sempre souberam da existência uma da outra. Figure-se que este homem faleceu e que agora as duas amantes pleiteiam sejam reconhecida em relação a elas a existência de união estável, para poderem participar da herança na condição de companheiras, porquanto passaram décadas de sua vida ao lado do homem. ${ }^{39}$

Suponha-se que uma corte tivesse de emitir sua primeira decisão a respeito de uma situação como essa, em que amantes querem ser reconhecidas como companheiras. Se, apesar de a matéria estar sendo trazida dessa forma pela primeira vez, em casos sobre temas ligados a amantes, união estável e casamento, o tribunal tivesse uma linha de precedentes com fundamentos que sempre prestigiassem a monogamia, afirmando que sempre que um dos cônjuges for casado qualquer relação com ele não será protegida pelo Direito $^{40}$, este valor - incentivo à monogamia - até então presente em todas as decisões da corte teria de ser considerado na decisão do leading case. O tribunal, mesmo sem estar vinculado aos precedentes que proferiu anteriormente porque a hipótese fática não era a mesma, teria de refletir acerca de seus julgados sobre temas conexos nos quais a monogamia foi prestigiada.

Essa reflexão poderia levar a que o tribunal demonstrasse e reafirmasse seu apego ao mesmo fundamento dos julgados anteriores, criando assim neste primeiro caso um precedente coerente com outros que já apresentava em matérias parecidas. Mas o resultado também poderia ser outro. A tanto bastaria que a corte agregasse em suas considerações outros fatores, tal como o tempo que duraram as relações extraconjugais, a contribuição que as amantes deram para a aquisição de patrimônio pelo homem falecido ou mesmo a incapacidade da esposa de perceber o adultério. De um jeito ou de outro, os precedentes anteriores da corte a respeito de assuntos conexos (mas não iguais) devem ser enfrentados na argumentação, para que a decisão da corte seja coerente com os fundamentos dos julgados que já proferiu, ainda que não sejam vinculantes. Os precedentes dos casos

\footnotetext{
${ }^{39}$ Exemplo livremente inspirado no RE 397762/BA, 1 ${ }^{\text {a }}$ T., Rel. Min. Marco Aurélio, maioria, j. em 3/6/2008, pub. DJE 12/9/2008, no qual o STF, em caso de relação paralela ao casamento, negou à amante o direito ao benefício previdenciário da pensão por morte, apesar de a relação ter durado 37 anos e gerado nove filhos. $\mathrm{O}$ STF afirmou que, sendo um dos cônjuges pessoa ainda casada de fato e de direito, eventuais outros relacionamentos mantidos são mero concubinato, não podendo ser equiparados com união estável.

${ }^{40}$ Por exemplo, a corte poderia ter entendimentos em matéria previdenciária, embora ainda não tivesse precedente específico em Direito de Família ou em Direito das Sucessões.
} 
análogos não seriam obrigatórios para o caso inédito, porque as regras jurídicas neles contida não foram produzidas para a mesma hipótese fática do caso agora sob julgamento. Mas, justamente porque eles dizem respeito à matéria parecida, eles inegavelmente devem exercer uma influência sobre o novo caso.

Essa necessidade de a corte abordar casos inéditos levando em consideração os fundamentos de seus precedentes sobre assuntos parecidos representa uma expansão de tais precedentes porque eles, mesmo sem serem vinculantes (por tratar-se de matéria nova), estarão de alguma forma reduzindo a discricionariedade do órgão julgador, o qual, apesar de estar livre para decidir como quiser o leading case, terá de fazê-lo enfrentando, para acolher ou rejeitar, os motivos (e não as ratio decidendi, que naturalmente não se aplicam a casos inéditos) dos precedentes existentes acerca de casos parecidos.

Constata-se, pois, que, em um modelo de prestígio dos precedentes, mesmo nos casos para os quais ainda não existe uma ratio decidendi, um precedente que seja relacionado é capaz de interferir e influenciar os casos seguintes, por meio de seus fundamentos. Tem-se aqui uma expansão do precedente que acontece não pela ampliação da abrangência de sua regra geral, mas pela utilização de seus fundamentos como argumento para a criação de outro precedente. 
DISTINÇÃO ENTRE PRECEDENTES

4.1. Distinção: conceito. 4.2. Distinção consistente: casos típicos. 4.3. Quem pode fazer o distinguishing? 4.4. A questão formal na distinção: a fundamentação. 4.5. Distinção inconsistente legítima e ilegítima. 4.6. Análise de casos concretos.

\subsection{Distinção: conceito.}

Conforme já foi dito em outras passagens deste trabalho, por razões de igualdade (mas não só) os precedentes devem se aplicar aos casos que lhes sejam assemelhados. Dessa forma, onde não houver semelhança, não há lugar para aplicação do precedente.

O que é vinculante e obrigatório para os casos seguintes não é todo o conteúdo da decisão, mas somente sua ratio decidendi, que é a regra jurídica usada pelo julgador para resolver um caso concreto precedente e que a partir dele se torna geral, abstrata e vinculante. Os aspectos laterais do caso, ainda que sejam teses jurídicas concretamente enfrentadas e discutidas pelo tribunal, não são de obrigatório cumprimento posterior. Daí a relevância de se identificar qual regra geral a ser extraída de um caso, o que é feito a partir de análise de algumas características do caso concreto (item 3.2).

Depois dessa identificação da ratio decidendi do precedente, para que ela seja aplicada aos casos futuros é preciso seja feita uma comparação entre o caso pretérito no qual foi firmado o precedente e o caso atual sob julgamento, em uma espécie de juízo de analogia. Essa comparação pode resultar na conclusão de que o caso atual é semelhante ou é distinto daquele do precedente. Somente a partir desse cotejo é que se pode concluir se é ou não hipótese de incidência ao caso atualmente sob julgamento a ratio decidendi proveniente do precedente.

É aí que pode acontecer a distinção (distinguishing). Primeiro, encontra-se a razão 
de decidir do precedente. Em seguida, os dois casos - o precedente e o atual - terão algumas de suas características comparadas e, a partir desse cotejo, será feita a conclusão sobre se os casos são realmente assemelhados, e por isso a razão de decidir do caso anterior deve ser repetida, ou se os casos são distintos, diferenciados, não sendo o caso de se aplicar a ratio decidendi do precedente. Para Luiz Guilherme Marinoni, "o distinguishing expressa a distinção entre casos para o efeito de se subordinar, ou não, o caso sob julgamento a um precedente" e "(...) revela a demonstração entre as diferenças fáticas entre os casos ou a demonstração de que a ratio do precedente não se amolda ao caso sob julgamento, uma vez que os fatos de um e outro são diversos". ${ }^{4}$

Assim, a distinção é uma técnica que consiste em não aplicar um precedente em princípio aplicável ao caso, mas que deixará de ser aplicado em decorrência da existência de alguma situação particular que justifica um tratamento diverso daquele contido na regra geral emanada do precedente. Se "onde há a mesma razão, aplica-se o mesmo direito" ( $u b i$ idem ratio, ibi idem jus), evidentemente onde não estiverem presentes as mesmas razões justificadoras da regra geral e abstrata existente no precedente ele não será aplicável, por razões de igualdade material e dinâmica e de justiça.

Existem duas formas de não se aplicar um precedente por dessemelhança. A primeira é a mais óbvia e acontece quando os casos são totalmente diferentes, hipótese em que sequer pode se falar em precedente, já que, se precedente houver, não foi cunhado para regrar fatos inteiramente diversos. A ratio decidendi não abrange fatos que lhe sejam estranhos. A segunda é a distinção propriamente dita, aquela que resulta da constatação de que o caso posterior é substancialmente diverso do caso anterior em razão da presença de um elemento que justifica o tratamento diferenciado.

A comparação entre casos acontece a partir da análise (1) dos fatos materiais/relevantes do caso anterior e do caso posterior; (2) dos valores e das regras envolvidos em cada um deles; (3) de qual a questão jurídica trazida para decisão (o pedido, e, por conseguinte, a decisão a ser dada) e (4) de quais os fundamentos para as respectivas decisões. Com o cotejo desses elementos se saberá se o caso seguinte é ou não semelhante ao caso anterior e, em consequência, se a ratio decidendi do precedente se aplica ou não.

\footnotetext{
${ }^{41}$ Precedentes obrigatórios, p. 326.
} 
Se os principais elementos tomados em consideração na primeira decisão se repetirem, isto é, se as razões que levaram à corte decidir precedentemente de um jeito e não de outro, também estiverem presentes no segundo caso, é hipótese de aplicação do precedente. Se existir algo substancialmente distinto, o precedente não deve ser aplicado, operando-se o distinguishing. Observe-se que não é apenas a diferença fática que pode ensejar a distinção entre dois casos. É preciso que sejam analisados os elementos (termo mais amplo que abrange todos os itens acima enumerados) de cada um dos casos para que possa vislumbrar a existência ou não de semelhança entre eles. Como se verá abaixo, um dado precedente pode não ser aplicável a um caso posterior, por exemplo, porque o fundamento que levou à decisão no precedente não está presente no caso seguinte, ainda que na perspectiva fática eles sejam assemelhados.

Para a realização de distinção não basta a existência, no caso subsequente, de um ou outro fato não considerado pela decisão anterior, assim como também não é suficiente que o caso precedente tenha levado em consideração um fato não existente no caso subsequente. É perfeitamente possível a existência de diferenças fáticas entre os dois casos em comparação. Somente se houver distinções materiais, que tornem os casos substancialmente diversos, é que o distinguishing deve ser feito. Por isso é que se diz que para a aplicação do precedente os casos não precisam ser idênticos, embora necessitem ser assemelhados. A distinção é apenas o outro lado da moeda. Para que ela ocorra, os casos precisam realmente conter elementos substancialmente diversos. Se a diferença não justificar tratamento diferente, não há que se falar em distinção. Assim, a distinção e a não aplicação do precedente só se justifica se concretamente existir um pormenor ou uma particularidade que torne a regra geral contida no precedente inaplicável ao caso concreto e que, com alto grau de probabilidade, se tivesse sido considerado pelo tribunal que apreciou o precedente, teria levado a julgamento diversos. Se no caso subsequente não estiver presente esse elemento materialmente distinto não há que se excepcionar a aplicação do precedente pelo uso da técnica da distinção, ainda que um ou outro detalhe de ordem fática seja diferente, até porque, a rigor, nunca se terá dois casos completamente idênticos. Sem uma efetiva diferença entre os casos, deve-se continuar aplicando o sistema de precedentes, garantidor de isonomia e de segurança jurídica. Qualquer distinção feita nessas condições será uma distinção inconsistente. 
Nesse contexto, diz-se consistente a distinção feita corretamente, quando presente algum elemento diferenciador que, se estivesse presente na decisão que levou ao precedente, teria ensejado solução diversa. Será inconsistente a distinção feita sem a presença deste elemento.

Observe-se que, quando se deixa de aplicar o precedente em decorrência da distinção consistente entre os dois casos (o precedente e o subsequente) não se está fazendo nenhuma crítica ao precedente (com as ressalvas que serão vistas abaixo, quando se tratar da distinção inconsistente legítima), que permanece válido. O distinguishing é uma técnica baseada nos elementos que circundaram o precedente, não em direito, isto é, na distinção não é feito nenhum juízo de valor a respeito do precedente. Apenas é constatado que os fatos não são os mesmos e que, portanto, o precedente na verdade não foi estabelecido para aquela específica situação presente e sim para outra, materialmente diferente. E, como uma das faces da isonomia é tratar diferentemente casos diversos, a aplicação do precedente seria errada, embora o precedente, em si, continue válido para as hipóteses subsequentes que sejam semelhantes a ele.

Em essência, a distinção quando feita de modo legítimo representa uma forma de permitir flexibilidade e evolução ao direito e ao próprio modelo precedentalista, com a criação de regras novas e diversas para casos novos e diversos. José Reinaldo de Lima Lopes, inclusive, em texto a respeito da importação, pelo Brasil, do modelo judicial norteamericano, depois de afirmar que tal importação foi incompleta, dentre outras razões, pela ausência de adoção da cultura jurídica do precedente, esclarece que o respeito aos precedentes não significa a fixidez e a imutabilidade das coisas. Dentre outras razões, o distinguishing é uma técnica que impede a aplicação cega do precedente, na medida em que os tribunais “(...) examinam até que ponto o caso sob seu escrutínio é igual ou diferente do caso que deu origem ao precedente. Por isso mesmo as decisões que fixam os precedentes têm em geral um exame mais minucioso dos fatos - muito mais minucioso do que é costume exigir no Brasil -, pois os limites de aplicabilidade do precedente são definidos pela característica dos fatos". ${ }^{42}$

${ }^{42}$ Modelos históricos do Judiciário: poder político ou poder neutro?, p. 24-25. 


\subsection{Distinção consistente: casos típicos.}

Como se viu, a distinção pode ser consistente ou inconsistente. Quando, no caso posterior existem elementos substancialmente diversos que, por si só, provavelmente justificariam uma decisão diferente no caso anterior se eles estivessem lá presentes, tem-se distinção consistente. Já quando não existe no caso posterior elementos diversos o suficiente para justificar porque a decisão no caso anterior teria sido diferente, a distinção é inconsistente.

A doutrina aponta alguns casos típicos em que o instituto da distinção consistente entre casos pode ser aplicado. O primeiro deles consiste na diferença fática entre eles. Já se afirmou que para a ratio decidendi de um precedente ser aplicável a um caso seguinte não é preciso que eles sejam idênticos, bastando que sejam assemelhados. No entanto, pode acontecer de o caso posterior ser similar àquele no qual o precedente foi fixado mas existir um diferencial que justifica, por si só, a não aplicação do precedente. É a hipótese mais tradicional de distinguishing.

Uma segunda hipótese de distinção consistente acontece no conflito entre precedentes de mesma hierarquia, aparente ou real. É que às vezes é possível a existência de precedentes emanados de uma mesma corte os quais aparentemente sejam conflituosos ou contraditórios entre si. Isso pode acontecer com maior intensidade em sistemas com elevada produção legislativa. Como a regra geral extraída do precedente advém de caso concreto no qual se discute a interpretação e a aplicação da legislação aplicável, esse cenário de existência de muitas leis pode acarretar, ao menos em um primeiro momento, precedentes total ou parcialmente conflituosos entre si.

Quando a análise de dois julgados deixa claro que o precedente mais recente simplesmente revogou o anterior, que passa então a não se aplicar mais, o problema não existe. Basta a aplicação do único precedente válido. Contudo, nem sempre se vai poder afirmar que essa revogação aconteceu, porque a situação subjacente aos dois precedentes pode ser complexa e por isso ter ensejado os precedentes aparentemente divergentes entre si. Além disso, não se recomenda a revogação implícita de precedentes apenas porque um 
mais recente aparenta entrar em conflito com um mais antigo, sendo conveniente aguardar manifestação expressa da corte vinculante sobre isso, já que a segunda decisão conflitante com a primeira pode ter sido proferida per incuriam, isto é, em erro, conforme se verá em seguida.

Os julgados em conflito precisam ser advindos da mesma corte ou de cortes com igual hierarquia. Quando se trata de cortes hierarquicamente diferentes não há que se falar em conflito. Deve sempre prevalecer o precedente da corte hierarquicamente superior, ainda que mais antigo.

Nestas situações, o julgador de um caso assemelhado a esses dois precedentes vai poder fazer a distinção em relação a um deles, para acompanhar o outro, ou mesmo estará autorizado a realizar a distinção em relação aos dois, numa tentativa de compatibilizá-los. Tem-se, nesta segunda hipótese, uma tentativa de harmonizar os dois precedentes, por meio de técnicas de ponderação e de convivência entre as regras contidas nos dois precedentes.

Também ocorre distinção consistente quando a corte que fixou o precedente incidiu em erro evidente, inadvertido, objetivamente aferivel e decisivo, naquilo que se costuma denominar de decisão per incuriam. Em que pesem os valores defendidos e buscados pelo modelo precedentalista, existem limites. A sua consecução não se deve dar a todo custo, nem de qualquer maneira. Por isso, se o julgador do caso seguinte constatar, de maneira objetiva (e não meramente subjetiva, em um juízo exclusivamente seu), que a corte estabelecedora do precedente agiu em erro, pode ele aplicar a distinção do caso atualmente em julgamento em relação ao precedente. $O$ erro pode ser de qualquer tipo, quer a respeito de uma questão relevante de fato, quer sobre questão jurídica (ignorar uma lei ou um precedente existente a respeito do assunto, ilustrativamente).

Contudo, para que a distinção seja consistente é necessário que o erro havido no precedente seja evidente, isto é, facilmente perceptível e claramente identificável a partir dos elementos objetivos contidos no próprio caso, sem necessidade de nenhuma influência de ordem subjetiva. Por exemplo, se para a fixação da regra geral do precedente a corte levasse em consideração como elemento essencial a idade da parte e posteriormente se 
percebesse que a idade por ela considerada estava errada à luz dos documentos constantes dos próprios autos.

Igualmente é preciso que o erro tenha sido inadvertido, ou seja, tem de se tratar de um erro efetivamente ocorrido. Acaso se perceba que, apesar de errada, aquela era realmente a intenção da corte, não se poderá falar em erro inadvertido e, portanto, uma distinção realizada será inconsistente. Uma coisa é a corte fixar um precedente sem conhecer - e, portanto, sem se pronunciar - o fato de uma lei ter sido parcialmente revogada por outra. Situação diversa é o tribunal negar que houve revogação. ${ }^{43} \mathrm{Na}$ primeira hipótese, o tribunal inadvertidamente errou ao fixar um precedente sem considerar que a lei por ele usada no caso concreto havia sido parcialmente revogada, circunstância que justifica o manejo da distinção para que o precedente errado não seja aplicado. Na segunda, por mais que alguém até possa entender que houve revogação, não se pode falar de erro, porque o tribunal discutiu o assunto e decidiu não ter havido revogação, o que não autoriza o uso do distinguishing.

Mas não basta que o erro tenha sido objetivamente evidente e inadvertido. É preciso também que ele tenha sido decisivo para a solução dada pela corte quando do julgamento do precedente. Ou seja, tem de ser erro a respeito de elemento que, acaso tivesse sido considerado pelo tribunal, a decisão teria sido outra. Erros a respeito de elementos irrelevantes para a regra jurídica fixada no precedente não justificam a distinção do caso posterior.

Também se pode invocar a distinção e deixar de aplicar a regra do precedente em uma quarta situação, precisamente quando o caso posterior cuida de fatos que a corte vinculante claramente não quis abranger. Figure-se um precedente cuja regra seja a de que aquele que apresentar recurso via fax tem inteira responsabilidade sobre a qualidade e a fidelidade dos documentos, não devendo ser conhecido o recurso quando a versão enviada por fax estiver ilegível. A regra foi cunhada sob a perspectiva de que a apresentação de recursos por meio de fax é autorizada pela Lei 9.800/1999 mas exige cuidado do recorrente sobre a chegada com qualidade e fidelidade da peça processual no órgão de destino, para

${ }^{43}$ Este exemplo, assim como o imediatamente anterior, são de Celso de Albuquerque Silva (Do efeito vinculante - sua legitimidade e aplicação, p. 251). 
que se possa compará-la com a versão original oficial que obrigatoriamente tem de ser juntada aos autos no prazo de cinco dias. Agora imagine-se que alguém recorreu via fax e, por um problema qualquer, o último parágrafo da segunda página das razões recursais chegou no destino borrado e incompreensível. No entanto, pelo restante do recurso se percebia claramente que o parágrafo que apresentou problemas dizia respeito apenas a um relatório do caso que havia sido feito antes das razões recursais em si e que o parágrafo borrado não impedia a compreensão do recurso nem sua comparação com os originais juntados tempestivamente.

Em uma situação como essa, o órgão jurisdicional pode proceder à distinção consistente, porque a regra geral contida no precedente não foi criada para abranger uma hipótese fática tão distante dos motivos que levaram à sua edição. É preciso, em casos tais, verificar a razão de ser da regra contida no precedente, que pode não se estender para todas as hipóteses formalmente por ela abrangidas. As razões de ser do precedente, os motivos que levaram à edição da regra nele contida, têm de ser extraídos a partir de dados contidos no próprio julgado precedente, sem interferência de elementos subjetivos pelo julgador vinculado. Dito de outra forma, quando o próprio precedente indica que sua intenção e finalidade não era abranger dada situação, permite-se a distinção, que será do tipo consistente. Nestas hipóteses, nas quais a regra do precedente é ampla e termina por abranger elementos bem diferentes daqueles que lhes serviram de justificativa, a técnica da distinção representa uma forma de restauração da isonomia e até mesmo de reforço do próprio precedente, considerando que sua demasiada abertura e generalidade poderia comprometer-lhe a credibilidade e a noção de justiça.

\subsection{Quem pode fazer o distinguishing?}

A obrigatoriedade do cumprimento de precedentes pelas cortes vinculadas advém do fato de que elas são parte de um todo orgânico e sistêmico destinado à solução de conflitos, que é o Poder Judiciário. Esse sistema é organizado de modo a existirem instâncias jurisdicionais hierarquicamente dispostas. Ao se falar em hierarquia, não se está aqui a tratar de prestígio, nem de importância. Cuida-se somente de constatar que, na definição das competências de cada órgão jurisdicional (juízos de primeiro grau e 
tribunais) feita pela Constituição e pela legislação processual, existem uns encarregados de rever as decisões dos outros, sendo este o sentido de hierarquia aqui referido. Uma corte é hierarquicamente superior pelo simples fato de poder rever, e mudar, o entendimento de um outro órgão jurisdicional, que, apenas por isso, lhe é inferior.

É dessa hierarquia que advém a obrigatoriedade do respeito aos precedentes pelos julgadores de inferior hierarquia. Eles estão vinculados ao precedente da corte hierarquicamente superior porque é pragmaticamente inútil e contraproducente desrespeitar o precedente, prejudicando a parte a quem o precedente beneficia, quando se sabe que a corte vinculante criadora do precedente pode (e provavelmente vai) restabelecê-lo. Em um tal contexto, o descumprimento do precedente significa mera teimosia, ainda que a resistência esteja sendo exercida a pretexto de uma suposta independência funcional do julgador, sendo que a recusa na aplicação do precedente causa prejuízo indevido à parte por ele beneficiado.

A distinção, contudo, não consiste na recalcitrância na aplicação do precedente. $\mathrm{Na}$ verdade, o reconhecimento da existência do precedente acontece, mas é acompanhado da afirmação, feita de modo assumido e fundamentado, de que ele por alguma razão devidamente exposta não se aplica ao caso concreto. Assim, por não significar uma negativa do precedente, a distinção pode ser feita por qualquer juiz ou corte vinculada, mesmo que de hierarquia inferior, diversamente do que acontece com o reconhecimento da superação do precedente, que só pode ser feito pela própria corte que o criou. Isso porque a distinção, em essência, de certa forma não deixa de ser uma reafirmação de que o precedente existe e segue válido, apenas não sendo hipótese de aplicá-lo no caso concreto.

\subsection{A questão formal na distinção: a fundamentação.}

Em passagem anterior já se mencionou que uma das vantagens do modelo de precedentes consiste em autorizar que o julgador do segundo caso, constatando a existência de um precedente a ele referente, esteja dispensado de maiores digressões a respeito das questões jurídicas, devendo apenas demonstrar a semelhança entre os dois casos, que é o que vai justificar a incidência da ratio decidendi do precedente. Essa prática conduz a uma 
das vantagens do emprego da técnica baseada em precedentes, que é a de aumentar a celeridade processual. As decisões baseadas em precedentes, por terem menos questões a apreciar, são mais simples, mais curtas, mais diretas, e, por conseguinte, proferidas com um consumo menor de tempo, permitindo que com uma mesma quantidade de recursos e de tempo, mais casos sejam apreciados (item 2.4).

Uma das consequências de um modelo de precedentes obrigatórios consiste, obviamente, na obrigação que tem o julgador do caso posterior de seguir o precedente. Neste passo, existindo um precedente a respeito de uma dada matéria que em princípio seria aplicável a um determinado caso concreto posterior, a regra é o órgão jurisdicional acompanhá-lo. Na hipótese de, por qualquer razão, o julgador resolver não aplicar o precedente que a rigor deveria incidir no caso posterior, será preciso uma fundamentação qualificada para demonstrar as razões pelas quais um precedente inicialmente obrigatório está deixando de ser cumprido, isto é, devem ser mostrados os motivos que levaram a decisão a não fazer incidir o precedente. Observe-se que há uma exceção à regra geral, que é a de seguir-se o precedente em decisões mais simples, menos complexas, e quando tal ocorre é por meio desta fundamentação qualificada que se vai poder perscrutar se as razões invocadas para não acompanhar o precedente são ou não válidas.

Com a decisão que aplica a distinção dá-se da mesma forma. Optando o julgador por não aplicar o precedente, terá ele dois deveres processuais que legitimarão o distinguishing. O primeiro consiste em assumir que está realizando uma distinção, demonstrando conhecer o precedente e seus fundamentos e razões. Isso é relevante não só para que as partes saibam que o órgão jurisdicional encarregado da solução de seus conflitos conhece os precedentes existentes a respeito da matéria mas também para que a corte vinculante, a quem a causa sempre deverá poder ser submetida em caso de recusa ao precedente, tenha conhecimento de que o afastamento do precedente aconteceu de modo transparente, explícito, e não dissimulado.

O segundo dever processual é o de explicar de modo particularmente fundamentado os motivos que levaram ao distinguishing. E só assim é que se saberá se a distinção foi ou não feita com base em critérios e parâmetros de diferenciação legítimos. 
Essa fundamentação qualificada é necessária porque, acaso se admita que qualquer grau de desigualdade entre os casos anterior e posterior justifica a não incidência da regra geral contida no precedente, isso será como se houvesse a negação de seu caráter vinculante, porquanto quase nenhuma outra hipótese fática estará sob seu comando. Em essência, isso seria negar o modelo precedentalista.

É preciso estar atento, então, a duas circunstâncias. Primeiro, que virtualmente nunca dois casos serão rigorosamente iguais. No limite, mudará ao menos o nome das partes, ou de seus advogados. Segundo, que nem toda diferença fática é relevante para o Direito $^{44}$, como por exemplo o nome das partes ou o de seus advogados. A individualização ampliada dos casos anterior e posterior significa que em última análise a regra geral do caso precedente terminará não se aplicando nunca. Daí a relevância da fundamentação qualificada a que se aludiu, dever processual que o julgador vinculado não pode deixar de cumprir, sob pena de possibilidade de desvirtuamento de todo o modelo precedentalista.

\subsection{Distinção inconsistente legítima e ilegítima.}

O distinguishing representa, em essência, a outra face do modelo precedentalista. Se tal modelo é marcado pela aplicação de regras iguais para casos semelhantes, naturalmente quando os casos não forem substancialmente os mesmos não há que se falar em aplicação da regra geral e abstrata egressa do precedente.

Evidentemente, sempre haverá uma ou outra distinção de ordem fática entre dois casos, porquanto duas situações dificilmente são rigorosamente iguais. Contudo, nem toda diferença fática justifica o tratamento diverso de dois casos. Entender-se o contrário poderia significar, em última análise, a própria negação do modelo de precedentes, porquanto os casos sempre tem uma diferença de maior ou menor grau a (supostamente) justificar a não incidência do precedente.

Dessa forma, assim como a aplicação do precedente passa pela etapa prévia de

${ }_{44}$ "Certas diversidades fáticas não constituem diferenças juridicamente relevantes", diz Patrícia Perrone Campos Mello (Precedentes - o desenvolvimento judicial do direito no constitucionalismo contemporâneo, p. 207). 
comprovar a similitude dos casos, a rejeição da incidência do precedente causada pela distinção entre os casos demanda que realmente exista um motivo legítimo para diferenciálos. Os mesmos valores e razões que norteiam o emprego de precedentes como forma de solução de controvérsias judiciais (item 2.4) igualmente justificam a técnica da distinção. Daí decorre que a distinção lastreada em fatos ou argumentos que não justificam o afastamento do precedente representará violação aos valores e razões que dão suporte ao modelo precedentalista, na medida em que estará tratando desigualmente situações substancialmente iguais, ainda que com algumas diferenças entre os dois casos. A pedra de toque, o critério principal para verificar se se está diante de um caso posterior realmente distinto do anterior deve ser a verificação, devidamente demonstrada e fundamentada, de que o elemento escolhido como fator de diferenciação entre o caso posterior e o anterior é relevante a ponto de permitir a afirmação de que o tribunal, se o tivesse levado em conta, muito provavelmente teria decidido de maneira diferente. Não se trata de um juízo de mera possibilidade, mas de elevada probabilidade de que a corte vinculante teria decidido diferentemente se o novo elemento tivesse sido por ela apreciado. Fora disso, o distinguishing será indevido. Tem-se, portanto, distinção inconsistente ilegítima quando se realiza a diferenciação do caso posterior em relação ao precedente invocando argumentos ou fatos que não explicam de modo plausível o porquê da diferença de tratamento entre eles.

Contudo, Melvin Aron Eisenberg afirma que nem todo uso de distinções inconsistentes é manipulativo ou indevido, apontando algumas hipóteses em que a corte faria uso legítimo delas. Uma dessas hipóteses aconteceria quando a corte estivesse insegura a respeito do acerto ou do equívoco no estabelecimento de uma nova regra e por isso, em vez de simplesmente revogar o precedente, temporariamente invocaria uma distinção inconsistente (já que a rigor não haveria distinção juridicamente válida entre o caso atual e o caso precedente) para não aplicar o precedente, como uma espécie de fase antes de decidir definitivamente por sua revogação. Ele diz que "por exemplo, uma corte pode acreditar que uma determinada regra substancialmente não possui congruência social nem consistência sistêmica e mesmo assim não ter certeza se essa sua impressão a respeito da regra está correta. A corte então faz uso de uma distinção inconsistentes como um passo provisório antes de uma completa revogação". 
Ainda sobre o uso de distinções inconsistentes como técnica para manter o precedente, mesmo que temporariamente, o autor lembra que, nos Estados Unidos, até 1930, havia um entendimento de que as obrigações gratuitas não eram exigíveis e que, a partir de 1940, o posicionamento das cortes mudou e passou-se a entender que tais obrigações, apesar de não serem acompanhadas de contraprestações, seriam exigíveis se a outra parte tivesse efetivamente acreditado nelas. Então ele explica, por meio de um exemplo, que nesse intervalo em que a mudança de entendimento foi acontecendo, uma corte pode ter inicialmente decidido que somente as obrigações gratuitas de depósito eram exigíveis, permanecendo as demais como de acordo com a regra do precedente, ou seja, inexigíveis. Nesta hipótese, a corte estaria fazendo uso de uma distinção inconsistente (em relação ao entendimento do precedente) como uma etapa para a regra geral que viria a ser fixada, segundo a qual todas as obrigações gratuitas, independentemente de sua natureza, seriam exigíveis. A distinção inconsistente aconteceria como forma de criar uma generalidade um nível abaixo daquela que representaria o rompimento total com o precedente. $^{45}$

Imagine-se que um determinado caso, a respeito do qual já existe um precedente, está para ser julgado pela mesma corte que estabeleceu o precedente. Se esta corte, por não vislumbrar seja correto, legítimo nem justo seguir a regra geral do precedente, resolver fazer uso de distinção inconsistente para afastar a incidência da ratio decidendi que seria inicialmente aplicável ao caso, pode-se dizer que a corte agiu, de certa forma, com prudência, embora tenha sido inconsistente com o modelo e tenha desobedecido a regra que ela própria criou.

É que às vezes a criação de uma distinção, ainda que tecnicamente inapropriada, é melhor do que simplesmente revogar desde logo o precedente, que seria algo final. Em alguns casos, a depender da matéria discutida, ou do momento em que a matéria é discutida, pode ser mais prudente e cauteloso a realização de distinções inconsistentes como uma forma de "testar" o novo entendimento antes de encampá-lo por inteiro e de modo definitivo, usando o caso diferenciado como uma espécie de "balão de ensaio" para verificar quais serão as consequências da decisão em todos os níveis. Dessa forma, com ${ }^{45}$ The nature of the common law, p. 135-139. 
uma decisão diferente daquela preconizada pelo precedente (que permanece válido), a corte pode sondar a repercussão do novo entendimento na doutrina, perceber seu impacto e aplicação pelas demais cortes e, sobretudo, perceber os efeitos sociais positivos ou negativos do que foi decidido. A crítica doutrinária, o impacto nas cortes vinculadas ou a verificação de malefícios sociais podem demonstrar à corte que a decisão não foi a melhor, quando então bastará a ela aproximar-se de volta de um precedente já existente e ainda válido, deixando de realizar distinções inconsistentes. Ou, diversamente, o tribunal pode constatar que seguiu o caminho correto e a partir daí avançar mais, deixando de usar distinções inconsistentes e chegar mesmo a revogar de modo definitivo o precedente. Em qualquer das hipóteses, essa conduta da corte - mesmo à custa do descumprimento injustificado de um precedente - aparenta ser mais responsável do que as mudanças feitas de modo abrupto, as quais podem acarretar consequências ainda piores.

Sabe-se que a fixação definitiva de um entendimento jurídico, notadamente quanto feita por um tribunal superior, pode trazer resultados relevantes, bons ou ruins, em diversas perspectivas (sociais, econômicas, fiscais, ligadas à segurança pública etc.). Se é assim com o estabelecimento original de um posicionamento jurídico, com mais intensidade ainda na mudança de entendimento. Por isso, desde que acompanhado da devida fundamentação qualificada, o emprego de distinções inconsistentes não é necessariamente indevido, podendo representar, na verdade, uma forma responsável de mudança, ou de manutenção, de entendimentos. Melvin Aron Eisenberg, inclusive, realça que "às vezes é mais indicado caminhar para um direito melhor em passos, mesmo ao preço da inconsistência durante a transição. Ao usar a técnica da distinção inconsistente, o tribunal pode simultaneamente mover o direito em direção a uma maior congruência social, proteger a justificada confiança social dada aos entendimentos anteriores, diminuir a justificada confiança futura neste entendimento e preparar o caminho para uma revogação do precedente que talvez não tivesse sido adequada se feita de outra forma". ${ }^{46}$

Mas não só a corte que fixou o precedente pode fazer uso legítimo de distinções

\footnotetext{
46 "It may sometimes be best to move to the best rules in steps, event at the price of inconsistency during the transition. By using the technique of inconsistent distinguishing, a court may simultaneously move the law toward social congruence, protect past justified reliance on the core of a doctrine, diminish the likelihood of future justified reliance, and prepare the way for an overruling that might not have otherwise been proper" (The nature of the common law, p. 139-140).
} 
inconsistentes em relação a ele. Também os órgãos jurisdicionais vinculados podem fazê-lo em alguns casos. Em sua função de resolver conflitos aplicando, quando for o caso, as regras gerais hauridas de precedentes, o julgador pode se deparar com entendimentos que, apesar de devidamente consolidados em precedentes, não se mostram mais corretos, sendo obsoletos, errados ou injustos. Tal ocorre, ilustrativamente, quando a regra geral do precedente foi cunhada sob outro contexto social ou histórico ou quando se constata algum tipo de repercussão negativa do entendimento do precedente.

As multas administrativas aplicadas pela Justiça Eleitoral para aqueles que não comparecem para votar nem justificam sua ausência são fixadas em valores muito módicos, normalmente alguns poucos reais. Aquele que não paga a multa deixa de estar quite com a Justiça Eleitoral e perde uma das condições de elegibilidade, não podendo ser candidato (art. 11, $\S 1^{\circ}$, VI, e $\S 7^{\circ}$, da Lei 9.504/1997). Imagine-se então, por hipótese, que o Tribunal Superior Eleitoral (TSE) estabelecesse um precedente com regra prevendo que, por ser módica a multa aplicada, a ausência de seu pagamento não poderia impedir a obtenção da quitação eleitoral porque a comparação do valor da multa com a retirada de um direito político tão importante quanto a capacidade eleitoral passiva demonstraria a desproporcionalidade da medida.

Agora imagine-se que esse precedente passou a ser seguido e, no médio prazo, como consequência dele, começa-se a perceber um incremento no número de eleitores que não comparecem às urnas, não justificam o porquê da ausência e não pagam a multa. Alguns juízes ou tribunais eleitorais, então, sob o argumento de que este cenário representa, na prática, o fim da obrigatoriedade do voto, em função de não haver mais consequências para a ausência às urnas, podem, apesar da regra contida no precedente $\mathrm{e}$ deles conhecida, invocar uma distinção inconsistente para negar aplicação ao precedente, provocando que a corte fixadora do precedente reaprecie a matéria, agora levando em consideração as consequências pretensamente negativas geradas pelo precedente. Ter-se-ia nesta hipótese o emprego de uma distinção inconsistente como forma de provocar a corte vinculante a ao menos rediscutir seu precedente. ${ }^{47}$ Veja-se que aqui o órgão jurisdicional

\footnotetext{
${ }^{47}$ A esse respeito, tornou-se famoso um excerto do voto do Lord Reid em julgado proferido pela House of Lords em "Jones v Secretary of State for Social Services (1972) AC 944 (HL), para quem "é notório que, quando uma decisão é desaprovada mas não pode ser revogada, as cortes tendem a realizar distinções inadequadas. Eu não acho que elas estejam agindo erradamente ao fazê-lo, elas estão adotando a solução
} 
vinculado está deixando de cumprir o precedente não por mera discordância, mas por razões maiores, lastreadas não no mero entendimento pessoal ou em independência, mas sim no aprimoramento do direito, que pode advir a partir das novas reflexões sobre o tema que podem vira a ser feitas quando for julgado o recurso contra a decisão que descumpriu justificadamente o precedente. ${ }^{48}$

Nas hipóteses em que a corte vinculante ou os julgadores vinculados fazem uso da distinção com essa finalidade evolutiva do direito, isto é, com vistas à rediscussão da regra contida no precedente, para que se verifique novamente seu acerto ou se é mesmo a hora de mudar, tem-se distinção inconsistente legítima. É inconsistente porque o parâmetro ou o critério escolhido para diferenciar os casos não é juridicamente importante e a rigor não justificaria um tratamento diferenciado em relação ao precedente. Mas é legítima porque a distinção não está sendo feita por teima ou por simples recalcitrância com o precedente, mas por existirem razões maiores a justificar a sua inobservância temporária, até que a regra nele contida seja reafirmada ou modificada.

Como a distinção inconsistente pode ser legítima ou ilegítima, nos casos em que o julgador esteja fazendo uso da distinção inconsistente de modo justificado, como forma de decidir de forma diferente um dado caso inicialmente enquadrável na regra geral contida no precedente, é recomendável que isso seja reconhecido de maneira expressa no julgado, por dois principais motivos. O primeiro, para que se saiba que o órgão jurisdicional assumiu a inconsistência da distinção. Esse dado é relevante porque diferencia a distinção inconsistente legítima daquela ilegítima, feita sem critério e sem motivo. Aqui o julgador reconhece que realmente não há entre os casos diferenças substanciais que sejam relevantes para o direito mas que, apesar disso, está elegendo a hipótese para aplicar um entendimento diferente pelos motivos que apresenta, sem que isso represente um rompimento com o precedente ainda válido.

menos ruim das alternativas que têm. Mas isso levará a incertezas" ("It is notorious that where an existing decision is disapproved but cannot be overruled courts tend to distinguish it on inadequate grounds. I do not think that they act wrongly in so doing, they are adopting the less bad of the only alternatives open to them. But this is bound to lead to uncertainty".

48 “A distinção inconsistente pode ter, contudo, uma função importante no desenvolvimento do direito. Ela pode representar a insubordinação das cortes vinculadas a precedentes errados, injustos ou obsoletos. Como estas cortes não têm poder para revogar tais julgados, elas se recusam a aplicá-los, a pretexto de estarem efetuando uma diferenciação entre casos, e provocam uma nova reflexão dos tribunais superiores, através do recurso das partes" (Patrícia Perrone Campos Mello Precedentes - o desenvolvimento judicial do direito no constitucionalismo contemporâneo, p. 207). 
No caso da distinção inconsistente feita pela própria corte autora do precedente, um segundo motivo pelo qual ela deve assumir explicitamente que emprega a técnica da distinção inconsistente como forma de decidir de modo diverso do precedente sem revogálo consiste na sinalização enviada para a sociedade de que a regra existente no precedente pode vir a mudar, embora o precedente, ao menos por enquanto, permaneça válido. Somente se a corte explicar e expor as razões pelas quais um caso em princípio subsumível ao precedente está sendo tratado - por enquanto apenas temporariamente - de modo diverso é que a sociedade terá como se sentir avisada de que o entendimento pode vir a mudar. Assim, se o emprego de distinções inconsistentes pode ser legítimo como uma fase de transição entre mudanças de regras extraídas de precedentes, isso apenas acontecerá se a corte efetivamente disser que o está fazendo com esta finalidade. Somente dessa forma a sociedade, aí incluídos as partes, os profissionais jurídicos e os cidadãos em geral, estarão formalmente advertidos e avisados de que o precedente existe, mas pode mudar, devendo pautar suas condutas a partir deste contexto de relativa incerteza e de possível mudança.

Quando a distinção inconsistente é feita por um juiz ou corte vinculada, também aqui se justifica a necessidade de que o órgão jurisdicional reconheça expressamente estar fazendo uso da técnica da decisão inconsistente. Isso para que a corte vinculante possa, ao apreciar eventual recurso manejado contra esta decisão, saber as razões pelas quais seu precedente não foi obedecido e conhecer os novos argumentos sobre os quais têm de refletir antes de decidir se mantém ou não o precedente. Se o precedente não foi seguido porque tornou-se errado, injusto, desatualizado ou trouxe consequências negativas, a corte vinculante precisa ser advertida disso mediante a exposição clara das razões do juiz ou da corte vinculada. Além disso, a exposição das razões pelas quais a regra geral contida no precedente não foi obedecida carece de ser explicitada também para que o órgão jurisdicional que a descumpriu demonstre que o fez com base em argumentos ainda não levados em consideração pela corte vinculante, ou seja, por motivos inéditos. Ao proceder desse modo, o julgador estará deixando claro que não se trata de assunto sobre o qual a corte vinculante já se debruçou e sim razões novas, afastando com isso qualquer suspeita de que o descumprimento do precedente aconteceu por teimosia ou mera divergência da solução dada pela corte superior. 


\subsection{Análise de casos concretos.}

A distinção feita pela Suprema Corte dos Estados Unidos da América no Caso Rasul v. Bush quanto ao Caso Johnson v. Eisentrager (prisão de estrangeiros no exterior)

Depois do rendimento incondicional da Alemanha na II Guerra Mundial, mas antes do rendimento do Japão, 21 soldados alemães foram encontrados por tropas norteamericanas na China, tendo sido aprisionados por permanecerem em combate mesmo depois do rendimento de seu país. Posteriormente, foram levados a julgamento por crimes de guerra, tendo o julgamento acontecido na China e sido feito por autoridades de uma comissão militar norte-americana. Depois da condenação, os 21 soldados alemães foram transferidos para solo alemão, na parte ocupada pelos Estados Unidos.

Lothar Eisenträger e outros desses soldados impetraram habeas corpus contra Louis Arthur Johnson, Secretário de Defesa dos Estados Unidos e contra o Secretário de Exército, além de outras autoridades a quem atribuíam a responsabilidade por suas prisões. Alegavam a inconstitucionalidade e a ilegalidade de suas prisões, tendo em conta a Constituição e a legislação norte-americana, além de violação a regras de Direito Internacional.

A District Court for the District of Columbia, juízo federal de primeiro grau, não conheceu do pedido, sob o fundamento de que o direito à petição de habeas corpus era condicionado à presença física do impetrante no território de jurisdição da corte.

Em grau de apelação, a Court of Appeals for the District of Columbia reformou a decisão de primeiro grau, argumentado que o direito a postular habeas corpus era garantido a todas as pessoas que alegassem estar sofrendo constrições em sua liberdade e as atribuíssem a autoridades americanas. Com isso, determinou que o pedido fosse apreciado pela primeira instância.

O caso, que ficou conhecido como Johnson v. Eisentrager, chegou à Suprema Corte em 17 de abril de 1950. Em 5 de junho de 1950, por maioria (6 X 3), foi negado aos 
impetrantes o direito de peticionar habeas corpus em uma corte americana porque:

a) a legislação não aboliu as naturais distinções existentes no mundo civilizado entre nacionais e estrangeiros, entre estrangeiros aliados e inimigos nem entre estrangeiros inimigos mas residentes e estrangeiros inimigos não residentes;

b) ao estender certos direitos constitucionais aos estrangeiros residentes, sempre foi claro que o motivo para tal extensão e a razão para existir juridição norte-americana era a presença do estrangeiro no país;

c) o poder do Executivo sobre inimigos estrangeiros, sem embaraços jurisdicionais, sempre foi historicamente assegurado, como forma de garantir a segurança nos períodos de guerra;

d) o termo "qualquer pessoa" existente na Constituição não estende sua proteção a estrangeiros inimigos que em qualquer lugar do mundo tenham sido hostis contra os Estados Unidos; e

e) a petição não demonstrou falta de jurisdição das autoridades militares que acusaram, julgaram e condenaram os prisioneiros, nem que eles agiram com excesso de poder. $^{49}$

Em resumo, a Suprema Corte decidiu que os tribunais norte-americanos não tem

\footnotetext{
${ }^{49}$ Há uma determinada passagem da decisão que resume bem a discussão: "Nós estamos discutindo uma decisão cuja premissa básica é saber se os prisioneiros fazem jus, como um direito constitucional, a verem instaurado em alguma corte dos Estados Unidos um processo de habeas corpus. Para responder afirmativamente nós teríamos de dizer que um prisioneiro de nossas autoridades militares está constitucionalmente garantido a fazer uso do ajuizar a medida mesmo se ele (a) é um estrangeiro inimigo; (b) nunca esteve nem residiu nos Estados Unidos, (c) foi capturado fora dos Estados Unidos e lá feito prisioneiro de guerra em uma custódia militar; (d) foi julgado e condenado por uma comissão militar sediada fora dos Estados Unidos; (e) por ofensas contra leis de guerra praticadas fora dos Estados Unidos; (f) e durante todo o tempo esteve preso fora dos Estados Unidos" ("We are here confronted with a decision whose basic premise is that these prisoners are entitled, as a constitutional right, to sue in some court of the United States for a writ of habeas corpus. To support that assumption we must hold that a prisoner of our military authorities is constitutionally entitled to the writ, even though he (a) is an enemy alien; (b) has never been or resided in the United States; (c) was captured outside of our territory and there held in military custody as a prisoner of war; (d) was tried and convicted by a Military Commission sitting outside the United States; (e) for offenses against laws of war committed outside the United States; (f) and is at all times imprisoned outside the United States") [Johnson v. Eisentrager, 339 U.S. 763 (1950)].
} 
jurisdição sobre alemães considerados criminosos de guerra por fatos praticados fora dos Estados Unidos e que estão custodiados em prisão na Alemanha, ainda que o julgamento tenha sido feito por norte-americanos e a prisão seja administrada pelos Estados Unidos.

Depois dos atentados terroristas ocorridos em setembro de 2001, os Estados Unidos passaram a ter uma legislação bem rigorosa em matéria de guerra, inclusive contra países e pessoas estrangeiras. Depois da declaração de uma guerra contra o Afeganistão, doze kuwaitianos e dois australianos foram presos por supostamente serem colaboradores do regime terrorista conhecido como Al Qaeda. Em seguida, foram transferidos para uma prisão que os Estados Unidos mantêm na Baía de Guantánamo, em Cuba, uma área arrendada por Cuba aos Estados Unidos com a única condição de que eles nunca a abandonem, detendo os Estados Unidos sua completa administração, apesar de a soberania permanecer com Cuba.

Em 2002, os parentes desses prisioneiros ajuízam habeas corpus perante a District Court for the District of Columbia, apontando o Presidente dos Estados Unidos como autoridade coatora e alegando basicamente que os presos (a) nunca praticaram atos de terrorismo nem lutaram contra os Estados Unidos e (b) foram custodiados sem acusação formal de nenhum tipo, sem acesso a advogado nem a qualquer tipo de defesa.

Tanto o juízo federal de primeiro grau quanto, apreciando apelação, a Court of Appeals for the District of Columbia decidiram que os juízes norte-americanos não têm jurisdição sobre o caso, invocando para tanto o precedente fixado em Johnson v. Eisentrager.

A Suprema Corte recebeu o caso, chamado de Rasul v. Bush, em 20 de abril de 2004. Em 28 de junho de 2004, de novo por maioria (6 X 3), o caso foi julgado. Dessa vez o direito de apresentar habeas corpus perante uma corte americana foi reconhecido, tendo sido feito o distinguishing relativamente ao Caso Johnson v. Eisentrager.

As principais diferenças entre os casos que levaram à distinção e, portanto, à não aplicação do precedente Johnson v. Eisentrager foram as seguintes: (a) os requerentes não 
são nacionais dos países em guerra com os Estados Unidos; (b) eles negam que tenham se envolvido em qualquer ato de agressão contra os Estados Unidos; (c) eles nunca tiveram acesso a tribunal nenhum, nem foram sequer acusados nem condenados por nada errado; (d) por mais de dois anos, estão presos em território sobre o qual os Estados Unidos exercitam exclusiva jurisdição e controle.

Em razão disso, a Suprema Corte afirmou que, diversamente do que ocorreu em Johnson v. Eisentrager, aqui em Rasul v. Bush o grau de controle exercitado pelos Estados Unidos em relação à Baía de Guantánamo é suficiente para justificar o processo e julgamento de habeas corpus quanto a fatos lá ocorridos.

Observa-se ter a Suprema Corte dos Estados Unidos realizado distinção consistente com base na diferença entre os casos. De fato, embora semelhantes em alguns pontos, existam questões que os diferenciavam a ponto de se poder considerar legítimo o distinguishing. Um dado que merece ser destacado é que a Suprema Corte, em diversas passagens da decisão, enfrentou e explicou de modo enfático os motivos que a estavam levando a distinguir e a não aplicar o precedente. Esse dado é muito relevante porque, além de mostrar à comunidade jurídica que o tribunal não desconhecia o precedente e nem estava sendo leviano em relação a ele, ainda deixou claro para os casos futuros quando e em que hipóteses se poderá aplicar o precedente do caso Johnson v. Eisentrager ou o do caso Rasul v. Bush.

\section{Distinção quanto ao sujeito passivo do IPTU}

A casuística brasileira apresenta um exemplo de distinguishing legitimamente reconhecido em três instâncias. Segundo o art. 34 do Código Tributário Nacional, consideram-se contribuintes do IPTU o proprietário do imóvel, o titular do seu domínio útil ou o seu possuidor a qualquer título. O STJ, interpretando este dispositivo, estabeleceu precedente afirmando a regra jurídica segundo a qual tanto o promitente comprador (possuidor a qualquer título) do imóvel quanto seu proprietário/promitente vendedor (aquele que tem a propriedade registrada no Registro de Imóveis) são contribuintes responsáveis pelo pagamento do IPTU, podendo o legislador municipal fazer qualquer 
opção permitida por este dispositivo, sendo lícita a definição do sujeito passivo do tributo como sendo o proprietário, o titular do domínio útil ou o possuidor a qualquer título ou, ainda, os três conjuntamente e solidariamente. ${ }^{50}$

Não obstante isso, em um caso do Rio de Janeiro, tanto o juízo de primeiro grau quanto o Tribunal de Justiça não aplicaram o precedente acima mencionado sob os seguintes argumentos:

a) no caso posterior não havia apenas um contrato de promessa de compra e venda do imóvel mas a particularidade de tal contrato ter sido firmado em caráter irrevogável e irretratável, com imediata imissão do promitente comprador na posse, tendo sido averbado no Registro de Imóveis, o que gera propicia que do contrato de promessa de compra e venda tome conhecimento tantos quantos se interessem;

b) tal contrato de promessa de compra e venda tinha sido lavrado há mais de trinta anos;

c) por conta disso, mesmo o nome do promitente vendedor ainda constando formalmente como se ele fosse o proprietário, já não há mais qualquer relação dele com o imóvel, motivo pelo qual não se justifica sua responsabilidade tributária pelo pagamento do IPTU; e

d) o precedente do STJ se direciona aos casos em que há contrato de promessa de compra e venda mas tanto o promitente-vendedor quanto o promitente-comprador ainda mantém vínculos com o imóvel, aquele porque ainda é o proprietário e pode deixar de levar adiante a promessa de compra e venda em caso de inadimplemento, retomando o imóvel, e este por ter o domínio útil imediato, isto é, por fazer uso direto do imóvel, além de ter a expectativa de adquiri-lo.

\footnotetext{
${ }^{50}$ Não se trata propriamente de um precedente na acepção correta do termo conforme se está acostumado nos modelos precedentalistas do common law. Esse entendimento foi firmado no REsp 1110551/SP, $1^{\text {a }}$ Seção, Rel. Min. Mauro Campbell Marques, unânime, j. em 10/6/2009, pub. DJE 18/6/2009, o qual tramitou sujeito ao regime do art. 543-C do CPC, ou seja, seguiu o modelo dos recursos especiais repetitivos. Em um modelo que aceita a vinculação aos precedentes por si mesma, como uma decorrência lógica do sistema e independentemente da existência de uma lei obrigando, essa tramitação diferenciada nem seria necessária. De todo modo, sua existência serve para confirmar que o STJ apreciou a matéria e decidiu sobre ela.
} 
Foi realizada, vê-se, uma distinção, tendo sido afirmado que um dos fundamentos jurídicos que levou o STJ a estabelecer o precedente não estava presente no caso posterior.

O Município do Rio de Janeiro, parte prejudicada com o afastamento do precedente porque deixou de poder cobrar o IPTU daquele que ainda constava oficialmente como proprietário do imóvel, recorreu ao STJ, postulando fosse reconhecido o erro na distinção realizada e pedindo fosse restabelecido o precedente.

O STJ, contudo, entendeu que, realmente, a razão que o havia levado a fixar o precedente não estava presente no caso, porque apesar de o promitente vendedor ainda constar como proprietário do imóvel, na verdade o contrato de promessa de compra e venda já tinha surtido seus efeitos e ele não tinha mais nenhum vínculo jurídico com o bem, devendo ser considerado sujeito passivo do tributo apenas o promitente comprador, nos moldes do contrato averbado no Registro de Imóveis. ${ }^{51}$

Tem-se aí uma hipótese em que o distinguishing foi realizado corretamente tanto na perspectiva formal quanto materialmente. Todas as decisões que afastaram a incidência da regra de direito contida no precedente assumiram que o estavam fazendo e apresentaram de modo particularmente fundamentado os motivos pelos quais o precedente do caso anterior não se aplicava ao caso posterior. Além disso, substancialmente realmente existiam motivos fáticos e jurídicos que afastavam o caso posterior da regra geral contida no precedente. Uma situação são os contratos de promessa de compra e venda que, enquanto são pagas as parcelas, tanto o promitente vendedor quanto o promitente comprador permanecem com vínculos em relação ao imóvel (aquele porque tem o imóvel como garantia do pagamento da dívida, este por já estar em sua posse). Outra bem distinta acontece quando o contrato de promessa de compra e venda é irretratável e o imóvel entregue imediata e incondicionalmente, uma vez que aí o promitente-vendedor não remanesce mais com nenhum vínculo diretamente com o imóvel apenas sendo credor de uma dívida relativamente ao promitente-comprador.

${ }^{51}$ REsp 1204294/RJ, $2^{\text {a }}$ T., Rel. Min. Mauro Campbell Marques, unânime, j. em 14/6/2011, pub. DJE 21/6/2011. 
O STF, no HC 81611/DF, decidiu que os crimes materiais contra a ordem tributária (crimes de sonegação fiscal) somente poderiam ser considerados consumados depois que o fisco concluísse em definitivo o processo administrativo de constituição do tributo devido. Até aí, a autoridade encarregada de dizer se o contribuinte realmente deve e, em caso afirmativo, quanto deve, ainda não teria se manifestado de maneira final a respeito da existência da dívida tributária, daí resultando que não se poderia falar em sonegação de um tributo que ainda não existe formalmente. Assim, decidiu-se haver falta justa causa para a ação penal pela prática de crimes de sonegação fiscal enquanto não houvesse decisão definitiva no processo administrativo de lançamento do tributo. ${ }^{52}$

No HC 83629/RN, a ordem de habeas corpus era postulada sob o fundamento de que a responsabilidade pelo pagamento da dívida tributária ainda estava sendo discutida no processo administrativo fiscal, razão pela qual o lançamento tributário ainda não era definitivo, não havendo justa causa para a instauração da ação penal. O STJ afirmou expressamente que não havia justa causa para a instauração de inquérito policial para a apuração de crimes de sonegação fiscal quando o suposto crédito fiscal ainda pendesse de lançamento definitivo, uma vez que a inexistência deste impede a configuração do crime, exatamente em consonância com o precedente do STF no HC 81611/DF No entanto, a decisão consignou que, "considerando as peculiaridades concretas do caso", existia uma diferença no presente caso, que não havia ocorrido no caso anterior do STF. Isso porque o que se discutia no âmbito administrativo era apenas a responsabilidade por um elevado débito tributário, cuja existência já tinha sido reconhecida. Ou seja, a dívida fiscal já tinha sido reconhecida, restando apenas saber quem era o responsável por ela. Em seguida, foi esclarecido que "uma coisa é desconstituir o tipo penal quando há discussão administrativa acerca da própria existência do débito fiscal; outra bem diferente é quando se discute na seara administrativa, tão-somente, a responsabilidade por um elevado débito fiscal já reconhecido". 53

Constata-se que o STJ praticou uma expressa distinção, mas baseada em

\footnotetext{
${ }^{52}$ HC 81611/DF, Pleno, Rel. Min. Sepúlveda Pertence, maioria, j. em 10/12/2003, pub. DJ 13/5/2005, p. 6. Posteriormente, esse entendimento foi resumido na Súmula Vinculante 24, aprovada em 2 de dezembro de 2009, segundo a qual "não se tipifica crime material contra a ordem tributária, previsto no art. $1^{\circ}$, incisos I a IV, da Lei 8.137/1990, antes do lançamento definitivo do tributo".

${ }^{53}$ HC 83629/RN, $5^{\text {a }}$ T., Rel. Min. Laurita Vaz, unânime, j. em 25/3/2008, pub. DJE 22/4/2008.
} 
argumentos de ordem fática e jurídica visivelmente inconsistentes. A análise do precedente cunhado pelo STF no HC 81611/DF deixa bem claro que a regra impede a instauração de qualquer tipo de persecução penal enquanto o tributo não estiver definitivamente constituído, isto é, lançado. O precedente não fez qualquer restrição a respeito de somente não existir justa causa quando a discussão administrativa for sobre a existência do tributo. Também as discussões administrativas sobre a quem compete o pagamento da dívida fiscal são relevantes, até para que não se venha a processar criminalmente alguém que, depois, foi administrativamente reconhecido como não sendo o sujeito passivo do tributo. Para o STF, enquanto a discussão administrativa não se encerrar, tenha ela que objeto tiver, o crime de sonegação fiscal não se consuma e, por isso, não há justa causa para a ação penal. A redução feita pelo STJ na abrangência do que foi decidido pelo STF foi indevida, lastreada em fatos inidôneos para justificar uma decisão diversa daquela do precedente, ocorrrendo, então, distinção inconsistente ilegítima.

O HC 90795/PE foi outro habeas corpus impetrado com vistas a que fosse aplicada a regra geral contida no precedente do STF no HC 81611/DF, desta vez no próprio STF. Os fatos cuidavam da apreensão de notas fiscais falsas as quais davam conta da prática de sonegação de ICMS. O STF fez o distinguishing argumentando que, apesar de se tratar de crime material contra a ordem tributária, ou seja, crime de sonegação fiscal, a imputação penal estava sendo feita com fundamento no emprego de documentos falsos, e não em pontos ligados à existência do débito, seu valor nem sobre seu devedor, daí resultando não ser necessário o aguardo do fim do processo administrativo fiscal. As questões referentes à responsabilidade pelas notas fiscais seriam apuradas no próprio processo penal. ${ }^{54}$

A redução que o próprio STF fez na abrangência e na abertura da regra contida no HC 81611/DF afigurou-se correta apenas no âmbito formal. O tema a respeito da distinção foi expressamente abordado e as razões pelas quais o precedente não se aplicava foram suficientemente dadas. No entanto, o critério material de distinção não se mostrou legítimo. É que, embora os fatos cuidassem da prática de sonegação fiscal por meio do uso de notas fiscais falsas, ainda assim era necessária a manifestação das autoridades administrativas fiscais para que dissessem se realmente o uso das notas fiscais falsas

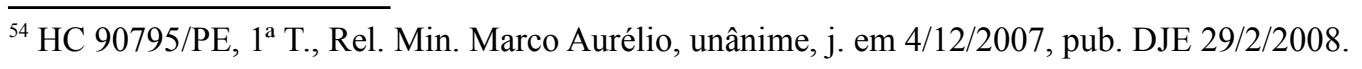


geraram a sonegação de algum tributo e, se afirmativo, qual o valor do tributo eventualmente sonegado. A pura e simples falsidade documental, sem que ela tenha efetivamente acarretado uma sonegação de tributos, não é crime contra a ordem tributária (art. $1^{\circ}$, caput e inciso III, da Lei 8.137/1990). Dessa forma, o crime objeto do HC 90795/PE continuava sendo um crime material contra a ordem tributária e, como tal, seguia carecendo de um processo administrativo fiscal que apurasse, em definitivo, a existência de uma dívida fiscal e qual seu valor. A pura e simples existência de notas fiscais falsas - que poderia até configurar outro crime de falso - não basta para que se diga existir crime contra a ordem tributária, sendo necessário saber se o tributo foi sonegado e seu valor. Tais informações, conforme a regra retirada do HC 81611/DF, só podem advir de decisão definitiva proferida em processo administrativo fiscal e sem ela o crime de sonegação fiscal não se consuma. Não houve, portanto, coerência do STF com seu julgado anterior, tratando-se de distinção inconsistente ilegítima.

\section{Distinção em súmula}

Em 2003, o STF editou a Súmula 691, conforme a qual "não compete ao Supremo Tribunal Federal conhecer de habeas corpus impetrado contra decisão do relator que, em habeas corpus requerido a tribunal superior, indefere a liminar". Ou seja: enquanto um habeas corpus não tiver sido definitivamente julgado por um tribunal superior, não cabe habeas corpus no STF, ainda que a liminar tenha sido indeferida.

No entanto, no julgamento do HC 85185/SP surgiu uma questão interessante. Todas as decisões constrangedoras da liberdade do paciente contrariavam o entendimento do STF no precedente fixado no HC 81611/DF, sobre o qual já se falou acima (no qual se estabeleceu a regra de que a consumação dos crimes de sonegação fiscal exige prévio exaurimento pleno do processo administrativo fiscal). Ou seja, tinha-se decisão meramente liminar do STJ, hipótese que, de acordo com a Súmula 691 do STF, não autorizaria sequer o conhecimento de habeas corpus pelo STF. Contudo, essa decisão liminar do STJ tinha sido dada em contrariedade com um precedente do STF amplamente divulgado e reiterado. E aí o STF teve de decidir se aplicava a súmula, não conhecendo do habeas corpus, ou se a afastava e restabelecia a autoridade de seu precedente. 
Nos debates travados por ocasião da apreciação do HC 85185/SP nenhum dos ministros deixou de reconhecer que a decisão liminar do STF realmente confrontava o julgado do STF no HC 81611/DF. A questão era saber que destino dar à Súmula 691, cujo teor impedia a análise do mérito e, sem analisar-se o mérito, não se teria como saber se a decisão liminar do STJ violava ou não o precedente do STF.

O Ministro Sepúlveda Pertence, então, sugeriu o cancelamento da súmula. Lembrou que as súmulas são apenas um instrumento de trabalho consistente em uma espécie de resumo do entendimento tranquilo do STF a respeito de um tema. Acrescentou que se o próprio STF estava admitindo a possibilidade de afastar a Súmula 691 e apreciar o habeas corpus mesmo se tratando de decisão que negou liminar, isso significava que a súmula não representava mais o entendimento seguro do tribunal a respeito do tema. Essa proposta foi recusada pela corte, sob o fundamento de que a questão deveria ser apreciada caso a caso. O Ministro Sepúlveda Pertence ainda tentou mostrar que representaria uma contradição primeiro verificar o mérito da impetração para ver se existia alguma hipótese excepcional que justificasse o abrandamento da Súmula 691 e, acaso essa excepcionalidade fosse encontrada, conhecer e apreciar o habeas corpus. As discussões prosseguiram, a Súmula 691 realmente não foi cancelada e, particularmente no HC 85185/SP, o habeas corpus foi tido por prejudicado e a ordem foi concedida de ofício para que fosse aplicado o entendimento fixado pelo STF no HC 81611/DF. ${ }^{55}$

Embora não se confunda com precedente, a súmula não deixa de conter uma regra, formulada por meio de um enunciado que pretensamente contém um entendimento pacificado da corte sobre um dado assunto. Dessa forma, como todas as regras, ela pode ser mais ampla do que o devido, ou pode entrar em confronto com outras súmulas ou com precedentes, de modo a necessitar de uma calibragem, de um temperamento. Por essas razões, é possível e até recomendável, em um modelo que trabalha com súmulas, que se permita a aplicação do distinguishing também em relação às súmulas, desde que presentes os requisitos gerais autorizadores do emprego da técnica da distinção. No caso do HC 85185/SP, a distinção foi feita corretamente, porque a aplicação cega da súmula 691 representaria uma ampliação sua de modo tal que ela se chocaria com o precedente oriundo ${ }_{55}^{5}$ HC 85185/SP, Rel. Min. Cezar Peluso, unânime, j. em 10/8/2005, pub. DJ 1\%/9/2006, p. 18. 
do HC 81611/DF.

Depois desse julgado no HC 85185/SP, o STF, em mais de duas centenas de casos, já afastou a incidência da Súmula 691 e apreciou o habeas corpus mesmo quando impetrado contra decisão que negou liminar, sob o argumento de que a súmula admite mitigação excepcional quando estiverem presentes flagrante ilegalidade, abuso de poder ou teratologia. ${ }^{56}$ Em que pese deva ser admitida a prática do distinguishing até em relação às súmulas, como uma válvula de escape para impedir sua aplicação indevida em algumas situações, quando as exceções a ela passam a ser tão frequentes e rotineiras talvez tenha chegado a hora de se refletir sobre se a regra enunciada na súmula de fato ainda corresponde ao que pensa o tribunal. Um dos valores subjacentes ao modelo precedentalista é a previsibilidade, a qual deixa de existir quando a regra passa a ser afastada com tanta frequência, o que pode dar a indesejada impressão de que a corte somente segue a súmula quando quer.

\footnotetext{
${ }^{56}$ Apenas por exemplo, confira-se os seguintes julgados: HC 112640/SP, $1^{\text {a }}$ T., Rel. Min. Dias Toffoli, unânime, j. em 7/8/2012, pub. DJE 14/9/2012; HC 114083/CE, $1^{\text {a }}$ T., Rel. Min. Rosa Weber, unânime, j. em 28/8/2012, pub. DJE 12/9/2012; HC 112731/RJ, $2^{\mathrm{a}}$ T., Rel. Min. Gilmar Mendes, unânime, j. em 25/9/2012, pub. DJE 10/10/2012; HC 112766/SP, $1^{\text {a }}$ T., Rel. Min. Rosa Weber, unânime, j. em 6/11/2012, pub. DJE 7/12/2012; HC 113119/SP, $1^{\text {a }}$ T., Rel. Min. DiasToffoli, unânime, j. em 13/11/2012, pub. DJE 4/12/2012. Esses eram apenas os mais recentes quando da confecção do trabalho mas, conforme afirmado, existem centenas de casos em que a aplicação da Súmula 691 foi recusada pelo STF.
} 
REVOGAÇÃO DE PRECEDENTES (OVERRULING)

5.1. Considerações gerais. 5.2. Revogação de precedentes e distinções inconsistentes legítimas. 5.3. Revogação de precedentes e crítica doutrinária. O papel e a importância da doutrina. 5.4. Overruling e sinalização. 5.5. Efeitos da revogação. 5.6. Papel da corte na revogação.

\section{1. Considerações gerais.}

Um dos principais argumentos contrários à adoção de um sistema de obediência a precedentes consiste em alegar que o desenvolvimento, a mudança e a evolução do direito fica prejudicada, uma vez que aos julgadores de inferior hierarquia nada restaria senão obedecer os precedentes fixados pelas cortes superiores.

De fato, um modelo precedentalista é marcado pela obediência das cortes aos precedentes estabelecidos. Isso não significa, em absoluto, a imobilidade do direito, representando apenas sua estabilidade e previsibilidade.

Uma das técnicas que asseguram a possibilidade de mudanças é o overruling, que é o nome dado, nos países cujo sistema é o common law, à revogação completa de um precedente. Em um primeiro momento, pode surpreender que um modelo calcado em isonomia, segurança jurídica, objetividade e previsibilidade admita um rompimento tão drástico com um entendimento até então apresentado como vinculante para todos os órgãos judiciários. Isso porque a revogação de um precedente pode representar tratamento diferente entre os casos julgados antes e depois da revogação, violando a isonomia, e pode retirar a previsibilidade dos jurisdicionados e dos profissionais jurídicos sobre como devem se comportar, em violação à segurança jurídica. Entretanto, se a técnica do overruling for corretamente praticada, a revogação dificilmente se dará de maneira abrupta. Trata-se de um processo que acontece de um modo relativamente paulatino e que, ainda quando tal não 
ocorre, busca preservar situações já constituídas. Dessa forma, embora durante algum momento realmente possa haver alguma insegurança ou instabilidade, o overruling na verdade vem a atender necessidades do modelo precedentalista, aperfeiçoando-o. A superação dos precedentes é necessária para permitir alguma liberdade decisória, autorizando que a corte, sem que isso signifique descumprimento de seus julgados (daí a importância das regras a respeito do overruling), possa deixar de aplicar precedentes considerados errados ou obsoletos.

De acordo com Melvin Aron Eisenberg, "o primeiro princípio que governa a revogação é o seguinte: um entendimento deve ser revogado se (i) ele substancialmente falha em satisfazer os padrões de congruência social e de consistência sistêmica e (ii) os valores subjacentes aos padrões de estabilidade doutrinária e o princípio do stare decisis os valores da isonomia, proteção da confiança justificada, prevenção de surpresas injustas, repetição e suporte - não serão melhores servidos pela preservação de um entendimento do que por sua revogação. Este é o princípio básico da revogação". ${ }^{57} \mathrm{Ou}$ seja, em resumo: é preciso que a regra contida no precedente tenha incongruência social e inconsistência sistêmica e sua revogação seja recomendável porque não há agressão à segurança jurídica (proteção da confiança justificada e prevenção de surpresas injustas).

De fato, quando ausente um sentimento social difuso de obediência, credibilidade e respeito pela regra oriunda do precedente, o direito perde o contato com a realidade e se torna difícil exigir seu cumprimento. As regras precisam ter argumentos sustentáveis por trás de si, para que mesmo os leigos consigam compreender que elas têm uma razão justificada de ser, ainda que eles não concordem com ela. Sem isso, ao menos para a sociedade, de muito pouco vai adiantar a previsibilidade, a segurança jurídica ou a

\footnotetext{
${ }^{57}$ No original: "The first principle that governs overruling is as follows: A doctrine should be overruled if (i) it substantially fails to satisfy the standards of social congruence and systemic consistency, and (ii) the values that underlie the standard of doctrinal stability and the principle of stare decisis - the values of evenhandedness, protecting justified reliance, preventing unfair surprise, replicability, and support - would be no better served by the preservation of a doctrine than by its overruling. Call this the basic overruling principle" (The nature of the common law, p. 104-105). Em passagem anterior o autor já havia explicado que a "repetição" tem a ver com a previsibilidade que os entendimentos repetitivos passam para as pessoas e para os profissionais jurídicos, os quais passam a poder se planejar como vão se comportar de maneira privada, sem usar o sistema judiciário, o que é mais barato, mais rápido e menos arriscado do que procedimentos judiciais, e que "suporte" significa a aceitação da regra do precedente por padrões gerais da sociedade ou padrões especiais do direito (The nature of the common law, p. 9-12).
} 
eficiência do modelo precedentalista, que antes de tudo precisa ser justo. ${ }^{58}$ É esse tipo de congruência social que as regras provenientes de precedentes precisam ter, sob pena de se deixar os jurisdicionados perplexos e descrentes relativamente às regras e ao aparato judiciário. ${ }^{59}$ Neste sentido, um precedente pode, com o passar do tempo e/ou a mudança de hábitos ou de valores sociais, começar a ser desacreditado, tornando necessária sua rediscussão e, eventualmente, sua mudança.

Já por consistência sistêmica se deve entender a harmonia entre as diversas fontes de regras jurídicas. Assim, se um precedente já não combina mais com leis supervenientes ou entra em conflito com outros precedentes ou mesmo com críticas doutrinárias sérias, a reflexão sobre seu abandono deve ser iniciada. O direito precisa ser coeso em seu todo, em sua unidade, de modo que seus componentes destoantes carecem de ser afastados. $\mathrm{O}$ overruling existe para permitir isso.

Observe-se que nem sempre que for verificada uma incongruência social ou uma inconsistência sistêmica o precedente deverá ser necessariamente revogado. É preciso que se faça uma comparação e uma análise de vantagens e desvantagens que pondere esses fatores ligados a questões de justiça (substantive reasons) com aqueles mais ligados à segurança jurídica, tais como isonomia, proteção da confiança justificada, prevenção de surpresas injustas e previsibilidade (formal reasons). Embora isso em princípio possa soar estranho em um país que adota o sistema da civil law, é sim possível ser mantida uma regra emanada de um precedente mesmo quando ela já não desperte na sociedade um sentimento de obediência, credibilidade e respeito ou ainda que ela conflite com outros precedentes ou com leis. Isso pode ocorrer quando parecer mais justo, correto e recomendável manter sem revogação um precedente mesmo com essas características se essa insistência em um

\footnotetext{
${ }^{58}$ Mesmo em sociedades - como aparenta ser a brasileira - ainda pouco conscientes de que as normas (em sentido amplo) devem ser cumpridas porque elas são obrigatórias, e não mera recomendação, e/ou que ainda sejam pouco permeáveis à noção de cumprimento de deveres, este sentimento social referido no texto existe. Em um tal contexto, as pessoas comumente têm conhecimento das normas e até concordam com elas; apenas, por diversas razões, não as cumprem, ou acham que só os outros é que precisam cumpri-las. Um outro dado relevante é que o fato de existir este sentimento de obediência, credibilidade e respeito não impede que exista discordância em relação ao conteúdo da norma. Porém, apesar do desacordo, ela é cumprida, sem prejuízo de esforços para modificá-la pelas vias próprias.

${ }^{59}$ Esclareça-se que não se está a afirmar que as decisões judiciais devem sempre atender a clamores e anseios populares. O que se quer dizer é que as decisões judiciais, mesmo as proferidas em caráter contramajoritário e em favor de minorias, precisam ser respeitadas pela sociedade, recebendo dela cumprimento e obediência mesmo em caso de discordância, e isso advém do fato de os jurisdicionados vislumbrarem nas decisões fundamentos razoáveis na perspectiva jurídica e fática (social).
} 
precedente falho se justificar para prestigiar a isonomia, a proteção da confiança justificada, a prevenção de surpresas injustas ou a previsibilidade. ${ }^{60}$ Patrícia Perrone Campos Mello lembra que a proteção da confiança é reforçada em determinadas áreas, por conta de suas particularidades. Esclarece que em questões ligadas à direito de propriedade, direito tributário, contratos, direito penal e responsabilidade civil a revogação de precedentes demanda mais cautela porque são temas em relação aos quais as pessoas normalmente depositam muita confiança nas regras estabelecidas, planejando-se e praticando condutas de acordo com elas. Já a revogação de regras contidas em precedentes sobre matéria processual, por exemplo, não estariam sujeitos a toda essa cautela. ${ }^{61}$ Como diz Melvin Aron Eisenberg:

“(...) talvez existam alguns casos nos quais um entendimento falha substancialmente em satisfazer os padrões de congruência social e consistência sistêmica e mesmo assim o princípio básico do overruling não estará satisfeito porque os valores subjacentes à estabilidade e ao princípio do stare decisis estarão mais bem servidos pela preservação do precedente do que por sua revogação. Nestes casos um segundo princípio ligado à revogação de precedentes tem lugar: um entendimento só pode ser revogado se, e somente se, as vantagens de tornar a regra socialmente congruente e com consistência sistêmica superarem os custos de não se observar os valores ligados à estabilidade e ao stare decisis. ${ }^{62}$

Os dois princípios mais importantes ligados à revogação de precedentes não se confundem mas estão intimamente relacionados. Em ambos, exige-se que o precedente e a regra nele contida apresentem incongruência social ou inconsistência sistêmica. Esse será o

\footnotetext{
${ }^{60}$ Embora sem realizar ponderações desse tipo, o STF em diversas oportunidades faz questão de consignar expressamente que está reafirmando sua jurisprudência sobre dado tema, apesar das considerações feitas pelas partes recorrentes, a demonstrar que nem todo questionamento do precedente, ainda que sejam apresentados argumentos novos supervenientes a ele, enseja revogação da regra. Por exemplo, nos seguintes casos: AgR no AI 819339/SP, 2 ${ }^{\mathrm{a}}$ T., Rel. Min. Ayres Britto, unânime, j. em 14/12/2010, pub. DJE 15/4/2011 (impossibilidade de redução de pena abaixo do mínimo com base apenas em atenuantes) e AgR no RE 415142/AL, 2 ${ }^{\mathrm{a}}$ T., Rel. Min. Ayres Britto, unânime, j. em 20/3/2012, pub. DJE 12/4/2012 (possibilidade de propositura de ações contra a União em qualquer dos domicílios dos litisconsortes ativos).

${ }^{61}$ Precedentes - o desenvolvimento judicial do direito no constitucionalismo contemporâneo, p. 254.

${ }^{62}$ No original: "(...) there may be some cases in which a doctrine substantially fails to satisfy the standards of social congruence and systemic consistency, and yet the basic overruling principle is not satisfied because the values underlying the standard of doctrinal stability and the principle of stare decisis would not be as well served by overruling as by preservation. In these cases a second overruling principle comes into play: such a doctrine should be overruled if, but only if, the advantages of making the legal rule socially congruent and systemically consistent outweigh the costs of not serving the values that underlie doctrinal stability and stare decisis" (The nature of the common law, p. 122).
} 
motivo pelo qual a regra já não se mostra mais consentânea e pode vir a ser revogada. Mas, além disso, requer-se mais. É preciso que (a) não exista violação à segurança jurídica (proteja-se quem justificadamente confiou no precedente, impedindo surpresas injustas) ou, se houver, (b) que essa violação seja compensada pelas vantagens decorrentes da revogação do precedente.

Ao analisar se é ou não mais compensador e recomendável a revogação de determinado precedente, a corte há de ponderar o nível de violação ao direito que a regra representa (a intensidade da incongruência social ou da inconsistência sistêmica) e o grau de adesão das pessoas e profissionais jurídicos à regra contida no precedente. É sopesando esses dois fatores que o tribunal concluirá o que compensa mais, manter o precedente apesar de suas falhas ou revogá-lo à custa de possível prejuízo para aqueles que confiaram nele.

Surge aqui uma questão interessante. Assim como um tribunal, ao criar pela primeira vez uma regra, tem de se preocupar não apenas com a solução a ser dada ao leading case mas com a regra que está sendo criada, considerando que ela se aplicará a todos os casos assemelhados (item 2.7), também por ocasião da revogação da regra essa análise há de ser feita. A corte precisa estar atenta e assumir às consequências internas e externas de suas decisões. Dessa forma, normalmente não só fatores puramente jurídicos são considerados, mas também os possíveis resultados, bons ou ruins, que podem advir da fixação ou da revogação do precedente. ${ }^{63}$ Trata-se do consequencialismo jurídico, isto é, o reconhecimento da existência de interpretações e de argumentos que, para além de serem jurídicos, também toma em conta as consequências deles que podem se projetar no mundo real e pragmático. ${ }^{64}$ Como, em um modelo de precedentes, as cortes fixam regras que vão

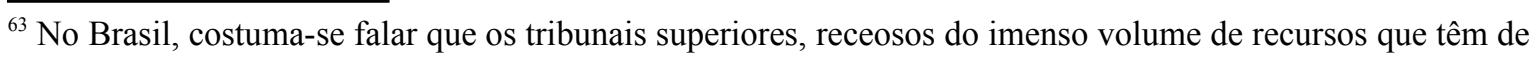
apreciar, adotam a chamada "jurisprudência defensiva", que consiste na fixação de entendimentos que terminam por criar dificuldades e restringir o acesso aos recursos extraordinários (recurso especial e recurso extraordinário propriamente dito). Normalmente tais entendimentos dizem respeito a exigências formais ou a interpretações mais limitadoras das hipóteses de cabimento do recurso. Esse tipo de decisão é um claro exemplo de análise, pela corte, dos impactos que advirão do entendimento que está a fixar. Por entenderem que, na prática, não terão condições de suportar um volume maior de recursos, exigências passam a ser feitas com vistas à redução do número.

${ }^{64}$ Não faz parte do objeto deste trabalho a discussão sobre a existência ou não de virtudes no consequencialismo. O enfoque aqui é o modelo precedentalista como técnica processual de solução de controvérsias. No entanto, no Brasil há pelo menos duas obras que se dedicaram com profundidade ao assunto. Apesar de serem obras voltadas ao Direito Tributário, existe nelas sólido conteúdo doutrinário a respeito do consequencialismo de um modo geral. Cf. Mizabel Abreu Machado Derzi, Modificações da
} 
ser aplicadas não apenas no caso concreto em que surgiram, é de certa forma natural que elas tentem vislumbrar e antever que consequências poderão advir da regra que estão a estabelecer.

Assim, verifica-se que a possibilidade de revogação das regras jurídicas constantes dos precedentes existem como forma de permitir ao direito sua mudança e o acompanhamento das alterações existentes na vida social, sem, contudo, descuidar-se dos valores ligados a um modelo de precedentes. Embora seja possível uma guinada súbita e uma revogação de precedente feita sem uma maior preparação ou sem demonstrações objetivas de que ela estava por acontecer, isso não é o que costuma ocorrer. Na rotina, a revogação de um precedente se dá como uma etapa natural de um processo evolutivo de mudança que já vinha de alguma forma sendo anunciado.

\subsection{Revogação de precedentes e distinções inconsistentes legítimas.}

Quando se tratou do distinguishing, na abordagem sobre as distinções inconsistentes legítimas (item 4.5), foi dito que elas podem representar uma etapa entre o afastamento do precedente em casos específicos e sua revogação completa. Por exemplo, quando o tribunal, mesmo vislumbrando que um seu precedente já não possui mais congruência social nem consistência sistêmica, ainda não tem certeza de que essa sua impressão a respeito da regra está correta, sendo mais conveniente, enquanto isso não se resolva, fazer apenas a distinção, ainda que inconsistente, e não a revogação completa. Ou então lançar mão de distinções inconsistentes legítimas para ir reduzindo a generalidade do precedente, que passaria a abranger cada vez menos situações, até o ponto de ser revogado. Nas duas hipóteses, tem-se uma sucessão de fases que vai da aplicação regular do precedente, passa por seu afastamento casuístico por meio da distinção e chega na superação completa consistente no overruling.

Essas decisões que fazem uso de distinções inconsistentes para afastar um precedente podem estar a revelar um precedente socialmente incongruente, isto é, uma

jurisprudência no Direito Tributário - proteção da confiança, boa-fé objetiva e irretroatividade como limitações constitucionais ao poder judicial de tributar, e Fábio Martins de Andrade, Modulação em matéria tributária - o argumento pragmático ou consequencialista de cunho econômico e as decisões do STF. 
regra que já não conta mais com patamares sociais mínimos de obediência, credibilidade nem de respeito, tendo sido inclusive necessária uma distinção inconsistente para não aplicá-la. Podem igualmente indicar um precedente sem consistência sistêmica, quer por conta da diferença entre o entendimento nele contido e o da distinção (inconsistência interna), quer porque a própria incongruência social pode significar que o precedente conflita com outros entendimentos hauridos de outras regras (inconsistência externa). Assim, por meio de decisões que aplicam distinções inconsistentes legítimas para não aplicar o precedente começam a surgir decisões divergentes sobre temas semelhantes, o que não é recomendado pelos valores defendidos por um modelo precedentalista: em alguns casos seria aplicado o precedente. Em outros, a distinção. Isso é inconsistência sistêmica.

A prática, por muito tempo, de decisões contraditórias (com o precedente) que aplicam distinções inconsistentes, mesmo que legítimas, pode levar à desigualdade. Por isso, em regra, é melhor revogar o precedente do que mantê-lo com esse custo. As questões ligadas à justiça (mudar a regra para ajustá-la à nova realidade) passaram a se sobrepor sobre aquelas ligadas à segurança jurídica (mantê-la para preservar isonomia, previsibilidade e os demais valores do modelo de precedentes), até porque esta, justamente por conta das inconsistências e contradições, já havia sido bastante reduzida.

Uma das vantagens do modelo precedentalista consiste em estimular as pessoas a pautarem suas vidas e suas condutas por regras que, além de já serem conhecidas, serão coercitivamente observadas, se necessário, sem diferenças injustificadas de tratamento, seja por que motivo for. As pessoas, então, atendendo a este estímulo e incentivo, passam a se planejar levando em consideração as regras existentes. É por isso que se diz que a técnica dos precedentes está intimamente relacionada com o valor da proteção confiança justificada, isto é, com o respeito àqueles que fizeram escolhas acreditando que a regra contida no precedente seria cumprida e observada.

Entretanto, a confiança depositada no precedente precisa ser justificada, feita com firmeza e com base legal. Se é insegura ou sem fundamento jurídico, a confiança dada ao precedente é sem razão. No caso de precedentes em relação aos quais já existem decisões 
aplicando distinções inconsistentes para reduzir sua incidência, dificilmente a confiança no precedente poderá ser tida como legítima, precisamente porque a regra já se encontra sob questionamentos. Melvin Aron Eisenberg aponta algumas hipóteses em que não se pode falar em confiança legítima: (a) pessoas que sequer sabiam que existia um precedente a respeito de dado tema não podem alegar confiança nele; (b) aquelas pessoas que, embora conhecessem o precedente, não consultaram profissionais especializados para saber em que estágio ele estava atualmente; (c) os que, apesar de terem consultado advogado, receberam um aconselhamento equivocado, porque o sistema não se responsabiliza por maus conselhos; (d) aqueles que consultaram profissional especializado, foram esclarecidos de que existia um precedente mas que em relação a ele já existiam decisões dissonantes e que, para o profissional, o precedente não representava mais a regra a ser seguida. Para o autor, em princípio, somente se poderia falar em confiança justificada em relação a quem, depois de feita a consulta a profissional especializado na matéria, foi dado conhecimento a respeito do precedente, das decisões divergentes existentes mas a opinião do profissional foi a de que o precedente ainda era a regra a ser observada. Mesmo assim, ele diz que pode faltar firmeza na confiança, já que a própria existência de decisões inconsistentes, notadamente quando essa inconsistência não segue nenhum padrão de argumentos, serviria para demonstrar que o precedente já não estava mais a merecer tanta credibilidade. ${ }^{65}$ Além disso, as distinções inconsistentes proferidas legitimamente com vistas a temporariamente não aplicar um precedente enquanto se analisa se é ou não o caso de revogá-lo definitivamente começam a surgir quando a congruência social ou a consistência sistêmica da regra passam a ser objeto de questionamentos, um contexto que diminuiria a legitimidade da confiança atribuída ao precedente.

A questão da proteção da confiança legítima se relaciona com o overruling porque a presença de uma confiança legitimamente posta na regra derivada de um precedente pode ser importante tanto para determinar se o precedente deve ou não ser revogado quanto para que se defina, na hipótese de revogação, como se darão seus efeitos.

Algumas cortes podem recear revogar precedentes porque isso poderia deixar os jurisdicionados e os profissionais jurídicos inseguros e sem muita confiança no cumprimento de precedentes. Este receio não se justifica quando se está a tratar de ${ }^{65}$ The nature of the common law, p. 110-111. 
precedentes em relação aos quais já existem decisões que os contrariam por meio do uso de distinções inconsistentes. Normalmente, quando se começa a fazer distinções inconsistentes legítimas em relação a um precedente é porque a regra nele contida, por alguma razão, já aparenta não ser a melhor. Provavelmente já existe algum tipo de incongruência social ou inconsistência sistêmica em relação à regra. Ademais, em um modelo precedentalista, quando as distinções inconsistentes começam a acontecer, a doutrina se encarrega de analisar se elas são legítimas ou ilegítimas, de modo que dificilmente a existência de uma distinção inconsistente legítima em relação a um precedente passa desapercebida. Em decorrência disso, a maioria das considerações feitas a respeito da proteção da confiança justificada se aplica no que diz respeito à prevenção de surpresas injustas.

A revogação de um entendimento até então sujeito a diversas decisões que não lhe cumpriam a pretexto de distinções que na verdade são inconsistentes, mas são legítimas, não é propriamente o que se pode chamar de surpresa. Um precedente com esta característica, embora não tenha perdido o caráter de obrigatório, demonstra seu enfraquecimento, na medida em que os julgadores ficam buscando diferenças inconsistentes para distinguir os casos que apreciam e retirá-los da incidência da regra. De todo modo, ainda que se pudesse falar em surpresa, ela dificilmente seria injusta. Em um tal contexto, todos os que estivessem lidando com a matéria objeto do precedente devem estar informados, ou deveriam estar, de que a regra apresentava alguma conotação de incongruência social ou de inconsistência sistêmica, que em muitos casos estava sendo afastada por meio de distinções inconsistentes e que, por isso, ela em breve poderia ser modificada.

Por razões parecidas, também não se pode falar em previsibilidade quando se verificam decisões que invocam distinções inconsistentes legítimas para não aplicar um precedente. Nunca se vai poder ter uma expectativa fundada de qual entendimento vai ser aplicado, se o contido no precedente ou se alguma decisão que lhe é contraditória.

Assim, constata-se que quando se tem decisões que afastam a incidência da regra do precedente com base em distinções inconsistentes legítimas (e são legítimas porque 
feitas com base na existência de incongruência social ou de inconsistência sistêmica) provavelmente haverá campo propício para a revogação total do precedente, porquanto o contexto em que ficam inseridas tais decisões usualmente afastam qualquer alegação ligada à segurança jurídica (isonomia, previsibilidade, proteção da confiança justificada, prevenção de surpresas injustas) que eventualmente pudesse justificar a permanência da regra mesmo com falhas de incongruência social ou de inconsistência sistêmica.

Um exemplo trazido por Melvin Aron Eisenberg é bem ilustrativo a respeito de como se opera a revogação a partir inicialmente de decisões contrárias ao precedentes proferidas com base em distinções inconsistentes legítimas. Nos Estados Unidos, até 1940, vigorava um precedente segundo o qual os hospitais de caridade eram imunes às regras de responsabilidade civil por danos. Dentre os argumentos invocados para tanto, alegava-se que: (a) as regras de responsabilidade civil só se aplicavam para instituições com fins lucrativos; (b) os beneficiários dos hospitais de caridade assumem o risco de sofrer algum dano; (c) obrigar os hospitais de caridade a pagar por danos poderia diminuir os recursos da instituição e desestimular doações, privando pessoas carentes do acesso à saúde; (d) é melhor que uma ou outra pessoa sofra prejuízos do que toda a sociedade ser prejudicada com a falta de recursos nos hospitais de caridade; e (e) alguém que é atendido por um hospital de caridade e depois ingressa em juízo contra ele demonstra bastante ingratidão.

Com o tempo, a esses argumentos foram opostos outros, tais como: (a) não é verdade que os beneficiários dos hospitais de caridade assumem o risco de sofrer algum dano; eles não procuram outro lugar no qual exista responsabilidade por danos simplesmente por não ter essa alternativa; (b) submeter os hospitais de caridade às regras gerais de responsabilidade civil não iria necessariamente extingui-los, tanto que existem hospitais que estão sujeitos a essas regras e são plenamente exitosos e prósperos; (c) mesmo se alguns hospitais de caridade deixassem de existir, o surgimento de seguros de saúde supriria sua falta; e (d) ainda que se trate de hospitais de caridade, um dano causado a um indivíduo tem de ser indenizado porque qualquer atividade, pública ou privada, deve pagar pelas faltas causadas por seu empregados, particularmente quando aquele que desempenha a atividade tinha condições de evitar o dano e o indivíduo não, sendo isso razoável e não ingratidão. Além disso, em decorrência da própria mudança e evolução da 
sociedade, surgiram algumas razões que implicitamente contrariavam o entendimento contido no precedente. Dizia-se que a possibilidade de contratação de seguro contra danos causados tornou a responsabilidade civil um custo igual qualquer outro, tal como pagar salários ou comprar suprimentos, não sendo mais necessária a concessão de imunidades. Observou-se que os hospitais de caridade passaram a ser dirigidos por executivos com dedicação integral, remunerados para tanto, e que o paradigma deixou de ser aquele hospital interiorano distante e tornou-se um grande hospital urbano, tudo profissionalmente administrado e sem maiores diferenças em relação a um hospital privado.

Essas mudanças tiveram repercussão nos julgados proferidos a respeito da matéria. Inicialmente, o precedente que negava responsabilidade civil aos hospitais de caridade começou a ser excepcionado em causas que eram movidas pelos empregados do hospital, sob o argumento de que aí não se tinha pedido feito por alguém que tinha sido beneficiado pela caridade. Depois a distinção se estendeu para abranger fornecedores do hospital, que também não eram beneficiários da atividade caritativa. Todas elas entravam em conflito com um ou com mais de um dos fundamentos do precedente que impedia a responsabilidade civil, tornando a distinção inconsistente.

E assim, gradativamente, as cortes foram apresentando argumentos os mais variados para contornarem o precedente, em sua grande maioria inconsistentes e insustentáveis à luz de algumas das razões que levaram à regra da irresponsabilidade civil dos hospitais de caridade. Seja como for, o fato é que a congruência social da regra (sentimento social difuso de obediência, credibilidade e respeito) foi diminuindo e as decisões contraditórias ao precedente crescendo. Em um tal contexto, tornou-se socialmente melhor e juridicamente mais recomendável a revogação do precedente. As razões de segurança jurídica (estabilidade, previsibilidade, isonomia) não estavam mais presentes e as razões de justiça material tinham tornado a permanência da regra não mais recomendável. ${ }^{66}$

A incongruência social e a inconsistência sistêmica que podem deflagrar o processo de revogação de um precedente pode decorrer de mutações sociais ou jurídicas. Isso porque a sociedade é complexa e está em constante alteração. Cabe ao direito, além de ${ }^{66}$ Exemplo retirado de Melvin Aron Eisenberg (The nature of the common law), p. 106-110. 
ser um dos fatores que influenciam e viabilizam a vida em sociedade, estar atento às mudanças ocorridas para que ele possa continuar exercendo de modo legítimo sua função de regramento. No que diz respeito à técnica de precedentes, as mudanças sociais, políticas, econômicas e culturais podem tornar reprovável uma regra antes aceita e permitir algo antes proibido, isto é, a evolução da vida social pode tornar errada uma concepção antes tida por certa, ou o contrário. Assim, se entre a edição de um precedente e os tempos atuais tiverem acontecido mudanças substanciais a respeito de dados fenômenos, pode ser que o precedente não mais se sustente e exista abertura para sua revogação.

Também as mudanças de entendimento jurídico podem ensejar a revogação de um precedente. É possível que novos argumentos contrários à regra contida no precedente surjam e sejam robustos o suficiente para demonstrar que tal regra não apresenta mais congruência social nem consistência sistêmica, ensejando a rediscussão e a mudança de entendimento na matéria. Por exemplo, a superveniência de leis a respeito de assuntos relacionados com o do precedente, mas não coincidentes com ela, podem, na prática, tornálo vazio ou obsoleto, recomendando a retirada da regra do sistema. Além disso, decisões de cortes inferiores pode acompanhar um dado precedente mas antes tecendo várias críticas em relação a ele, consignando que ele já não contempla mais uma boa solução jurídica. A corte que editou o precedente pode tomar conhecimento destas críticas, encampá-las e, a partir delas, revogar a regra. A mutação jurídica pode ser apontada também pela doutrina, cujo papel em um sistema de precedentes merece uma análise específica, o que será feito em seguida (item 5.3).

Quer por mutação jurídica, quer por mutação social, quer pela evolução e alteração natural do direito e da vida em sociedade, o fato é que nenhuma regra extraída de nenhum precedente tem a pretensão de ser eterna. Para garantir previsibilidade e segurança, o direito deve ser estável, mas não imutável. Por isso é que uma regra que um dia foi correta e seguida de modo vinculado por todos pode, aos poucos, ir perdendo credibilidade e respeito, deixando gradativamente de ter congruência social e consistência sistêmica e ser forte candidata à revogação. Mesmo que isso ocorra, durante algum tempo, a regra prevaleceu, foi acertada e respeitada. Existem casos, contudo, em que o precedente pode ser, já desde o início, errado, ou seja, é possível a existência de regras que já sejam 
equivocadas, incongruentes e inconsistentes desde a origem.

Desta forma, a revogação de um precedente pode acontecer quando a corte constata que a regra nele contida é, e sempre foi, errada. É diferente, portanto, da mutação jurídica. Aqui a regra esteve dentro daquilo que se compreendeu como jurídico durante algum tempo, embora depois tenha se tornado errada, ou indevida, por razões supervenientes. É possível, contudo, que um tribunal constate e reconheça que uma regra por ele instituída sua sempre foi equivocada e que, por isso, resolva revogá-la. Isto pode acontecer, por exemplo, quando o tribunal assenta sua decisão preponderantemente em premissas que posteriormente venham a se mostrar falsas mas a corte, quando revogou o precedente, não tinha conhecimento disso. Trata-se do "déficit de informação", um argumento do qual a corte pode fazer uso quando ela não tiver atentado para uma questão de fato ou de direito absolutamente relevante e que levaria a uma decisão completamente diferente daquela que terminou sendo estabelecida.

Para reduzir ao máximo as chances de acontecer "déficit de informação" e em consequência dele uma regra ser fixada de maneira errada, no caso no qual será fixado o precedente o tribunal deve se valer ao máximo de instrumentos e técnicas que possam lhe ajudar no julgamento. Por isso, além de ser uma forma de democratização do Poder Judiciário e de reforço de sua legitimidade, a participação de terceiros (amicus curiae) antes do julgamento dos casos nos quais um precedente será estabelecido e a permissão para que eles tragam esclarecimentos de todo tipo a respeito do que será julgado aumenta a qualidade da decisão a ser proferida pela corte. ${ }^{67}$

Em todos esses casos, a ausência de congruência social e de consistência sistêmica pode ser verificada pelo surgimento de decisões que buscam fugir da incidência do precedente por meio da aplicação de distinções inconsistentes legítimas. Quando isso acontece, torna-se possível a discussão sobre a revogação ou não do precedente, a qual

\footnotetext{
${ }^{67}$ Atualmente, existe a previsão para a participação de terceiros no art. 14, § $7^{\circ}$, da Lei 10.259/2001 (Lei dos Juizados Especiais Federais), no art. 543-A, $\S 6^{\circ}$, e no art. 543-C, $\S 4^{\circ}$, ambos do CPC (na redação da Lei $11.418 / 2006$ e da Lei 11.672/2008, respectivamente), inclusive por meio de audiências públicas. “(...) Conceber as manifestações sociais em processos deliberativos como o direito de condicionar a tomada de decisões estatais vinculativas é uma imagem republicana de uma sociedade policêntrica, em que os polos decisórios não representam nichos de concentração de poder, mas o equilíbrio entre os pontos de vista existentes no corpo comunitário, o balanceamento centrífugo das forças sociais, ainda que divergentes" (Antonio do Passo Cabral, Os efeitos processuais da audiência pública, p. 202).
} 
dependerá da análise sobre se ainda existe confiança legítima a se proteger e surpresas injustas a se evitar e, acaso haja, o que é mais ponderado e compensador, manter a regra em nome da segurança ou relativizar esta, revogar o precedente e aperfeiçoar o direito.

Evidentemente, não basta que uma decisão divirja de um precedente por meio de distinção inconsistente legítima para que se tenha sua revogação. Primeiro, porque essas decisões contraditórias devem ser admitidas por um tempo razoável, ainda que à custa de alguma insegurança jurídica e falta de previsibilidade, justamente para que se saiba se a revogação do precedente é mesmo a medida mais correta a ser feita. Segundo, também para que, acaso o overruling seja mesmo efetuado, os jurisdicionados e os profissionais do direito disponham de um período de transição para ajustarem suas condutas antes da revogação por inteiro do precedente.

Além disso, nem sempre que há divergência com base em distinção inconsistente legítima acontece overruling em sua acepção total. A distinção inconsistente pode ocorrer não em relação à revogação completa do precedente, mas apenas para reduzir em alguma medida sua abrangência, deixando ele de atingir uma ou alguma situação fática ou jurídica específica, isto é, pode-se ter uma revogação meramente parcial da regra contida no precedente. Isso,

Essas duas possibilidades, contudo, não invalidam a afirmação de que decisões contraditórias ao precedente proferidas com fundamento em distinções inconsistente legítimas são um forte indicativo de que o overruling deve ser praticado.

\subsection{Revogação de precedentes e crítica doutrinária. O papel e a importância} da doutrina.

Em um modelo de precedentes, por pragmatismo, as partes e os profissionais do direito normalmente deduzem suas argumentações invocando aqueles julgados que acreditam conter a regra aplicável aos seus respectivos casos, cabendo ao julgador decidir se há realmente precedente a respeito do assunto e, se existir, qual é ele, ao que se segue a aplicação ao caso concreto da regra abstrata e genérica nele contida. 
Mesmo assim, o papel da doutrina segue sendo relevante. É que por meio dela é possível evoluir a ponto de se chegar mesmo à revogação completa de um precedente ainda que ele não esteja enfrentando relativizações judiciais casuísticas feitas por meio de distinções inconsistentes legítimas. No modelo precedentalista, cabe à crítica doutrinária proceder à análise técnica e científica dos precedentes existentes, apresentando-lhes, quando for o caso, seus erros, os quais podem gerar tanto incongruência social quanto inconsistência sistêmica. Com isso se quer dizer que a tão só crítica doutrinária, quando sólida, autorizada e disseminada, pode bastar para justificar que uma corte realize o overruling de um precedente que editou, na medida em que a doutrina demonstre efetivamente que o tribunal está a operar com precedente que apresenta incongruência social ou inconsistência sistêmica.

A fixação de um entendimento por um tribunal, por maior que seja sua hierarquia, não necessariamente encerra as questões nem os debates existentes a respeito do assunto decidido, podendo na verdade até incrementá-los. E é conveniente que seja desse jeito. Por mais informada que tenha sido a decisão do precedente, alguns argumentos sempre podem não ter sido apreciados, nem considerados. Alguns, inclusive, pode ser supervenientes, ou ter surgido somente a partir do próprio precedente. Dessa forma, assim como o estabelecimento de um precedente é interessante como forma de otimizar e acelerar o julgamento das causas a respeito do tema, também é extremamente recomendável que a doutrina permaneça estudando inclusive as matérias já decididas para que as possíveis falhas existentes sejam expostas e o direito possa evoluir. Os passos do direito rumo a uma eventual modificação do precedente podem ser dados enquanto a aplicação do precedente vai permitindo a solução mais rápida, previsível e isonômica dos conflitos. Até a crítica doutrinária sobre um dado assunto atingir um nível de robustez hábil para infirmar o precedente, este segue sendo aplicável aos casos concretos semelhantes. Desta forma, cada um desempenhando seu papel, a evolução do direito causada pela doutrina e a eficiência na resolução de conflitos por meio dos precedentes caminham lado a lado, passando a interagir a partir de quando se constata que a crítica doutrinária atingiu um patamar tal que talvez seja o caso de revogar, ou ao menos rediscutir, o precedente. 
Quando um precedente não tem mais congruência social nem consistência sistêmica e isso é exposto de maneira clara e sólida pela literatura especializada, normalmente as razões ligadas à segurança jurídica que poderiam justificar a permanência da regra do precedente começam a se enfraquecer, abrindo campo para a revogação. A crítica doutrinária séria e respaldada pode representar, ela mesma, uma demonstração de que falta ao precedente consistência sistêmica, porquanto ele, embora não conflite diretamente com outros precedentes nem com a lei, está se confrontando com uma doutrina de tal modo qualificada que não pode mais ser considerado inteiramente harmônico com o sistema jurídico considerado como um todo. Melvin Aron Eisenberg, inclusive, realça que "se a um entendimento falta substancialmente congruência social e consistência sistêmica e isso foi demonstrado pela literatura profissional, os valores subjacentes aos padrões de estabilidade e ao princípio do stare decisis normalmente serão mais bem atendidos pela revogação do que pela preservação do entendimento, mesmo que ele não esteja sendo questionado judicialmente". ${ }^{68}$

Afora isso, a existência de rigorosa crítica científica quanto a um precedente afasta a confiança justificada e a possibilidade de surpresas injustas, porque vozes autorizadas já proferiram de maneira convincente o alerta de que aquela regra pode não ser a melhor nem a mais recomendável a ser seguida. O caminho para a revogação do precedente, portanto, pode ser considerado aberto.

Em outro exemplo trazido por Melvin Aron Eisenberg, ele lembra que nos Estados Unidos da América durante algum tempo prevaleceu o entendimento de que uma criança nascida com alguma deformidade ou lesão decorrente de negligência praticada durante o estado fetal não tinha direito à obter indenização de nenhum tipo. Alegava-se que (a) não existia dever de cuidado em relação a pessoa que ainda não existia e (b) permitir o ingresso em juízo com pleitos dessa ordem iria estimular a fraude, considerando a dificuldade de provar a relação de causa e efeito entre a negligência e a deformidade ou lesão.

Vários doutrinadores começaram a demonstrar que esse entendimento não era

\footnotetext{
${ }^{68}$ No original: "If a doctrine substantially lacks social congruence and systemic consistency, and that has been brought out in the professional literature, the values that underlie the standard of doctrinal stability and the principle of the stare decisis will normally be no better served by preservation than by overruling, even if the doctrine is not jagged" (The nature of the common law), p. 119-120.
} 
correto nem se sustentava juridicamente. Era dito que: (a) as chances de fraude em uma demanda dessa natureza não são maiores nem menores que em demanda pedindo indenização por negligência em momento posterior ao estado fetal, principalmente considerando o estágio atual da medicina; (b) o argumento de que o dever de cuidado não se estendia à pessoa ainda não nascida não tinha explicação razoável, notadamente porque conflitava com preceitos de outros ramos do direito, inclusive o Direito Penal, o Direito Processual e com o próprio Direito Civil, na parte relativa ao direito de propriedade, em todos eles havendo o reconhecimento de direitos para o nascituro.

A doutrina abalizada apontava que esse entendimento não tinha congruência social porque era difícil explicar à sociedade as razões pelas quais um dano ou deformação causado no período pré-natal não era indenizado e um dano causado no período pós-natal era. Além disso, havia também inconsistência sistêmica porque o tratamento dado à situação no âmbito da responsabilidade civil não era o mesmo dado em outras áreas, sem qualquer justificativa para tanto, notadamente porque a legislação aparentava proteger mais o nascituro, e não prejudicá-lo. Nesse contexto, confiar na permanência de um precedente subjeito a essas críticas ou ser surpreender com uma eventual revogação sua não seria justificado, já que a possibilidade de ocorrer o overruling já estava sendo reconhecida amplamente pela doutrina especializada. De tanto sofrer críticas, o precedente foi, afinal, revogado, passando-se a se reconhecer a obrigatoriedade de indenizar também as lesões ocorridas no período pré-natal. ${ }^{69}$

Contudo, é importante ressaltar, até como forma de preservação do modelo e por razões de segurança jurídica, que não é toda crítica doutrinária que é suficiente para se ter como reconhecida, por meio dela, uma incongruência social ou inconsistência sistêmica. A crítica doutrinária precisa ser reconhecida objetivamente como sólida, abalizada, significante. Normalmente a crítica ao precedente é acompanhada por muitos doutrinadores, que convergem ao apontar suas falhas e ao apresentar os argumentos para tanto. A crítica pontual, eventual, que represente apenas discordância é natural, democrática e sempre vai existir. Só que para fins de considerá-la como suficiente para justificar um reconhecimento público de que não há mais no precedente congruência social nem consistência sistêmica é preciso algo mais qualificado e mais robusto. A doutrina ${ }^{69}$ The nature of the common law, p. 119-121. 
quando reúne essas características pode fazer as vezes do que fazem as decisões que contraditam o precedente por meio de distinções inconsistentes legítimas, isto é, podem abalar a convicção de que a regra contida no precedente ainda deve ser tida por válida.

\subsection{Overruling e sinalização.}

Como se viu anteriormente, existem duas formas básicas de se perceber que um precedente pode vir a ser revogado. A primeira delas é a existência de decisões que são com ele contraditórias, proferidas com base em distinções inconsistentes legítimas. A segunda é a crítica doutrinária, que quando é feita de modo sólido, fundamentado, reiterado e disseminado é suficiente para que seja considerada como um anúncio de que a regra pode ser definitivamente afastada. Vê-se, pois, que a prática de distinções inconsistentes legítimas ou de crítica doutrinária são marcos objetivamente verificáveis relativamente à possibilidade de um precedente ser revogado. São meios de externar a falta de congruência social e de consistência sistêmica de uma regra.

Quando esses marcos objetivamente verificáveis não existem não se pode - ao menos não com a desejável segurança - afirmar que os requisitos necessários à revogação do precedente foram atendidos. Nesse contexto, passa ter lugar uma técnica conhecida como sinalização, por meio da qual um tribunal segue o precedente mas expressamente sinaliza, avisa, que aquele precedente já não é mais confiável.

\subsection{Efeitos da revogação.}

A atividade jurisdicional, como regra, é retrospectiva, ou seja, aplica-se a fatos que já ocorreram quando a decisão é proferida. Em um modelo precedentalista, não só a decisão do caso concreto é proferida relativamente a fatos passados como também a regra estabelecida em um precedente retroage para se aplicar, em razão de sua característica vinculante, a todos os casos assemelhados, ainda que ocorridos anteriormente a seu surgimento. Acrescente-se que, assim como a criação judicial de regras abstratas, genéricas e vinculantes por meio de precedentes não viola o princípio da legalidade (item 2.6), a aplicação da regra do precedente a casos que aconteceram anteriormente à seu surgimento 
também não viola o princípio da irretroatividade das regras, ou pelo menos não o contraria mais do que o contrariaria uma decisão qualquer que se aplicasse a fatos já ocorridos. Isso porque, conforme anteriormente mencionado, a aplicação de precedentes vinculantes é apenas uma técnica de solução de conflitos, assim como também o é aquela existente no modelo que não reconhece obrigatoriedade na observância de precedentes. Em matéria de aplicação de leis, não há nada de diferente entre as duas.

Já se disse aqui que, em um modelo precedentalista, a atividade jurisdicional, mesmo quando resolve casos cujos fatos ocorreram antes dela, tem um caráter prospectivo. Como as cortes sabem que, por meio do precedente, estão a criar regra que será aplicada também a casos futuros, espera-se delas a consciência da responsabilidade que isso acarreta, porque a solução que eventualmente se mostrasse ideal para um dado caso pode não necessariamente ser a melhor para todos e isso precisa ser refletido e ponderado na decisão que estabelece a regra. O modelo de precedentes obrigatórios, portanto, é sempre também prospectivo, porque o precedente vinculante é voltado a se aplicar nos casos futuros.

Mas existe também uma outra forma de prospectividade, essa ligada especificamente ao overruling. Normalmente um tribunal, ao revogar um precedente, simplesmente o faz, sem maiores considerações a respeito do dia inicial para que a nova regra passe a ter validade. Quando a revogação acontece nesses termos, entende-se que ela tem validade desde já, estendendo-se a todos os casos ainda não julgados e vinculando todos os julgadores que ainda não tiverem proferido decisões nos casos semelhantes.

No entanto, em algumas situações, as cortes têm preferido fixar expressamente um marco temporal a partir do qual a decisão que reviu o precedente passa a ter validade. É o que se denomina revogação prospectiva (prospective overruling). Às vezes, nem o caso que serviu para justificar a revogação do precedente e a instituição de uma nova regra é por ela abrangido. A casuística apresenta hipóteses as mais diversas nas quais a mudança de entendimento, por exemplo: (a) se aplica ao caso em que houve a revogação do precedente, aos casos futuros e a todos os casos passados, inclusive aos que já transitaram em julgado (retroação total - algo possível em matéria penal quando a revogação favorece o réu); (b) 
se aplica ao caso em que aconteceu a revogação, aos casos futuros e todos os casos passados, exceto aqueles que já tiveram julgamento final definitivo (retroação parcial); (c) não vale para o caso presente, só para fatos futuros ocorridos depois da data do julgamento, aplicando-se aos casos anteriores o precedente revogado (prospecção total); (d) incide no caso em que a revogação aconteceu e aos fatos ocorridos posteriormente a ele; (e) incide no caso em que a revogação aconteceu e às demandas posteriores a ele, independentemente de quando os fatos tenham ocorrido; (f) só se aplica a partir de uma data especificamente determinada; ou (g) só para casos que ainda não atingiram determinada fase processual.

Como se vê, as alternativas são muitas e a opção por uma delas vai depender daquilo que o tribunal achar que melhor atende à conciliação entre o afastamento de um precedente que já não se mostra mais acertado e o respeito à segurança jurídica. Em linhas gerais, a revogação do precedente com efeitos apenas prospectivos permite decisões mais audazes, rompimentos mais intensos com o direito anterior e mudanças maiores, na medida em que as situações passadas estarão sendo preservadas. Já o overruling com retroação é mais recomendável para alterações de entendimento mais suaves, cujo impacto nos fatos já ocorridos seja menor, considerando que fatos praticados enquanto prevalecia o entendimento anterior da corte terminarão sendo atingidos pela nova regra.

Quando se tratou da ratio decidendi, foi dito que ela é a regra que se extrai de um caso concreto e que, por ter os atributos de generalidade e abstração, passa a ser aplicável também a outros casos futuros assemelhados, de modo vinculante. Embora seja obtida a partir do julgamento de um caso concreto, a ratio decidendi não se confunde com o dispositivo da decisão. Este sim é o que contém a solução dada ao caso concreto exclusivamente. Essa diferença entre ratio decidendi e dispositivo fica bem evidenciada quando se estuda a revogação prospectiva, notadamente nos casos em que a corte revoga o entendimento, mas aplicando os efeitos da revogação somente para frente, excluindo da incidência da revogação inclusive o próprio caso que ensejou a mudança. Em uma tal situação, a nova regra advinda da revogação do precedente anterior a rigor era completamente desnecessária para a solução do caso concreto. Mesmo assim, o tribunal a criou, aproveitando-se do caso para aperfeiçoar o direito, permitir que ele evolua, ainda que tal aperfeiçoamento, por outras razões também justificadas, não se aplique ao caso 
presente.

O que se tem na técnica da revogação prospectiva é o exercício, pela corte, de prudência e responsabilidade. Tem-se a revogação do precedente mas com a cautela de, quando necessário, somente aplicar a mudança doravante, ou a partir de um dado momento claramente estabelecido.

O prospective overruling pode ser aplicado sempre que a corte perceber que a regra contida em determinado precedente, apesar de não ser mais socialmente congruente nem apresentar coerência sistêmica, permanece sendo observada pelas pessoas e pelos profissionais, o que pode acontecer por várias razões, dentre elas o simples respeito aos precedentes. Nestas hipóteses, a simples revogação do precedente não se mostra correta, sob pena de se violar a segurança jurídica. Dessa forma, para proteger a confiança justificada dada ao precedente ou para prevenir surpresas injustas, o tribunal muda desde logo a regra, valendo-se de um caso para trazer de volta coerência e congruência ao direito, mas dosa a incidência dessa mudança, afastando-a de outros casos nos quais, se a mudança de entendimento fosse a eles aplicada, poder-se-ia deixar desprotegidos aqueles que depositaram uma justificada confiança no precedente anterior ou a eles causar surpresas injustificadas. Com isso se atende tanto ao valor segurança, porquanto aqueles que acreditaram legitimamente no precedente não serão prejudicados, quanto ao valor justiça, porque o direito terá evoluído, se desenvolvido e se aperfeiçoado. ${ }^{70} 71$

\footnotetext{
${ }^{70}$ Por construção jurisprudencial, o TSE entendia que o prazo para ajuizamento de ação com base no art. 30A da Lei 9.504/1997 era de 180 dias contados da diplomação do candidato. A Lei 12.034/2009 reduziu esse prazo para quinze dias, mantido o mesmo marco inicial. O TSE, então, passou a decidir que sua jurisprudência permanecia aplicável a todos os casos ajuizados até a entrada em vigor da Lei 12.034/2009, já que aqueles que confiaram no entendimento do TSE não poderiam ser prejudicados nem surpreendidos. Confira-se, por exemplo, o AgR-REspe 3857533-São Paulo/SP, Rel. Min. José Antônio Dias Toffoli, unânime, j. em 4/9/2012, pub. 17/9/2012, p. 24. Não é bem o caso de revogação de um precedente por outro, mas de revogação de um entendimento pela lei, tendo o tribunal levado em consideração questões ligadas à segurança jurídica para fins de deliberar os efeitos da lei em relação ao entendimento até então aplicável.
}

${ }^{71}$ O STJ já validou decisão de corte inferior que decidiu conforme a jurisprudência do STJ que era a dominante quando a decisão foi proferida, ou seja, manteve a aplicação de jurisprudência que posteriormente veio a ser superada, em nome da segurança jurídica. No HC 121284/RJ, $5^{\mathrm{a}}$ T., Rel. Min. Napoleão Nunes Maia Filho, unânime, j. em 16/3/2010, pub. DJE 26/4/2010 foi dito que “(...) 1. A jurisprudência dos Tribunais Superiores aponta a prévia conclusão do procedimento administrativo fiscal como condição objetiva de punibilidade na ação penal; assim, não havendo a pré-apuração do crédito fiscal tido por fraudado, impõe-se declarar não haver crime a ser investigado e, menos ainda, denúncia-crime a ser apresentada. 2. Entretanto, este entendimento, hoje pacificado, já oscilou nos dois sentidos e, neste ponto, cumpre esclarecer que à época dos fatos e do oferecimento da denúncia, a solução então adotada pelo TRF da 2a. Região, de que o encerramento do processo administrativo era prescindível à propositura da ação penal, 
A doutrina lembra que, em direito público, não é incomum que o Poder Legislativo edite leis que contornem decisões judiciais que aumentam a responsabilidade do poder público ou que, em matéria fiscal, beneficiam o contribuinte. Imagine-se, então, que, em decorrência da revogação de um precedente, um tributo que até então era cobrado deixará de incidir. A corte pode ter a fundada expectativa de que essa sua decisão será mudada pelo Legislativo, que editará uma lei deixando claro que o tributo incide inclusive na hipótese afastada pela corte (em tribunais estaduais, essa convicção pode vir, por exemplo, da experiência verificada em outros estados). Nessa hipótese, ter-se-ia a sucessão de três regras: primeiro, a regra do precedente original, entendendo incidir o tributo; depois, a regra proveniente da revogação do precedente, afastando a incidência do tributo; e, por fim, a regra legislativa, fazendo com que o tributo volte a incidir. Para evitar uma situação como essa, não recomendável por trazer insegurança jurídica, a corte pode realizar uma revogação prospectiva dizendo que a revogação da regra anterior não só não vale para o caso presente como também só será aplicável depois de encerrado o ano legislativo seguinte. Com isso, o tribunal se acautela e tenta evitar a instabilidade que decorreria da sucessão seguida de regras, dando tempo ao Poder Legislativo para que, se quiser, edite nova lei a respeito do assunto. ${ }^{72}$

Em que pese a vantagem de conciliar os valores segurança (proteção da confiança e proibição de surpresas - formal reasons) com justiça (aperfeiçoamento e evolução do direito - substantive reasons), a revogação prospectiva apresenta alguns inconvenientes. Ela pode gerar, por exemplo, decisões incoerentes e inconsistentes. Quando uma regra é

ainda prevalecia nas Cortes Superiores. 3. In casu, não configura constrangimento ilegal a execução de sentença penal condenatória, já transitada em julgado, porquanto à época do oferecimento da denúncia, a jurisprudência então dominante nas Cortes Superiores resguardava de legalidade a propositura da ação antes do lançamento definitivo do crédito tributário. 4. Ordem denegada, em conformidade com o parecer ministerial". No HC 166984/ES, 6a T., Rel. Min. Og Fernandes, unânime, j. em 7/12/2010, pub. DJE $7 / 2 / 2011$, o entendimento foi reafirmado, tendo restado decidido que “(...) 1. O entendimento desta Corte e do Supremo Tribunal Federal é no sentido de que a constituição definitiva do crédito pelo lançamento é condição necessária a validar a justa causa para o oferecimento da ação penal, nos crimes insertos no art. $1^{\circ}$ da Lei $n^{\circ} 8.137 / 90$. 2. Inexiste, todavia, constrangimento ilegal em execução de sentença penal condenatória, já transitada em julgado, quando, à época do oferecimento da denúncia, a jurisprudência então dominante nas Cortes Superiores resguardava de legalidade a propositura da ação antes do lançamento definitivo do crédito tributário. 3. Ordem denegada".

De fato, seria uma aparente incoerência o STJ reformar decisão que aplicou a jurisprudência então dominante do próprio STJ. O efeito das decisões que mudam jurisprudência, portanto, seria ex nunc, prospectivo e não retrospectivo. Observe-se que esse as duas decisões cuidam de matéria penal e eram prejudiciais ao réu, circunstância que não foi suficiente para levar à retroação da alteração do entendimento jurisprudencial.

${ }^{72}$ Melvin Aron Eisenberg, The nature of the common law, p. 130. 
revogada mas os efeitos da revogação somente são aplicáveis a partir de determinada data, aos fatos que acontecerem até o dia anterior à data estipulada será aplicada uma regra sabidamente já ultrapassada e formalmente considerada como não sendo a melhor, o que em princípio não se justificaria. Apesar de a crítica ser procedente, se em uma determinada hipótese o tribunal verifica que precisa proteger aqueles que acreditaram e seguiram o precedente, um marco objetivo precisará ser criado, para que a nova regra não se aplique a fatos anteriores a ele. É um custo inevitável, por assim dizer.

Um outro problema decorrente da prática da revogação prospectiva seria o fato de que as partes e os profissionais jurídicos deixariam de se preocupar com a possibilidade de mudança e de evolução do direito. Isso aconteceria porque, com o prospective overruling, eles saberiam que as situações estabelecidas à luz da regra anterior, por mais equivocadas e criticadas que fossem, sempre seriam respeitadas. Embora o modelo precedentalista tenha por um de seus fundamentos justamente estimular a previsibilidade, não é recomendável que as partes e os profissionais jurídicos sequer admitam a possibilidade de mudança porque isso lhes reduz o estímulo para propor e argumentar por alterações e aperfeiçoamentos no direito, na medida em que tais mudanças, se acontecerem, não lhes beneficiarão. Isso impediria a evolução do direito.

Por mais válidas que sejam as críticas, as vantagens de se conseguir harmonizar segurança jurídica com evolução do direito superam as possíveis falhas, notadamente quando se percebe que a revogação apenas prospectiva da regra contida no precedente segue sendo medida excepcional. Somente quando existir uma regra socialmente incongruente ou sem coerência sistêmica que, mesmo assim, seja legitimamente acompanhada pelas pessoas. Nesta hipótese a regra precisa ser afastada mas a confiança das pessoas igualmente precisa ser tutelada, para que elas não sejam indevidamente surpreendidas. Como não é sempre que isso acontece, porque usualmente quando uma regra perde congruência social ou coerência sistêmica a confiança das partes e dos profissionais na regra já naturalmente se reduz, a revogação imediata do precedente permanecerá sendo o mais comum e o prospective overruling não será tão frequente assim a ponto de as falhas a ele apontadas se tornarem tão insuportáveis que passem a não mais recomendar seu emprego quando necessário. Deste modo, o efeito mais comum nas 
revogações de precedentes é o retroativo, porque quando uma regra vai gradativamente se tornando socialmente incongruente ou perde coerência sistêmica paralelamente a confiança no precedente vai diminuindo e não haverá mais surpresa se ele for revogado. E, mesmo quando essa consciência paulatina de que o precedente pode vir a ser revogado não acontece, a corte pode ser valer da técnica da sinalização para deixar expressamente demonstrado que o entendimento pode ser revisto a qualquer tempo. Com isso, a necessidade de revogação prospectiva diminui significativamente.

No Brasil, a revogação prospectiva é conhecida como modulação de efeitos e está prevista no art. 27 da Lei 9.868/1999 (que dispõe sobre o processo e julgamento da ação direta de inconstitucionalidade e da ação declaratória de constitucionalidade perante o Supremo Tribunal Federal) ${ }^{73}$ e no art. $4^{\circ}$ da Lei 11.417/2006 (a qual disciplina a edição, a revisão e o cancelamento de enunciado de súmula vinculante pelo Supremo Tribunal Federal $)^{74}$. A leitura dos mencionados dispositivos demonstra que a regra é a retroatividade e a prospectividade a exceção, somente podendo ser praticada se pelo menos oito dos onze ministros concordarem com a modulação dos efeitos e, na hipótese do art. 27 da Lei 9.868/1999, somente se for reconhecida a inconstitucionalidade (e não a constitucionalidade).

\subsection{Papel da corte na revogação.}

Em um primeiro momento, poder-se-ia supor que, se uma corte pode ela mesma revogar um precedente que criou, na prática isso significaria que ela não tem obrigação de honrar seus próprios precedentes. Tal, contudo, não é verdadeiro. A obrigação de aplicação dos precedentes aos casos subsequentes se aplica, igualmente, à corte que estabeleceu o precedente, que também tem o dever de respeitá-lo. No modelo de precedentes obrigatórios, o tribunal tem o dever de coerência em relação às suas próprias decisões, existindo aquilo que se costumou denominar de "eficácia horizontal dos precedentes".

\footnotetext{
${ }^{73}$ Art. 27. Ao declarar a inconstitucionalidade de lei ou ato normativo, e tendo em vista razões de segurança jurídica ou de excepcional interesse social, poderá o Supremo Tribunal Federal, por maioria de dois terços de seus membros, restringir os efeitos daquela declaração ou decidir que ela só tenha eficácia a partir de seu trânsito em julgado ou de outro momento que venha a ser fixado.

${ }^{74}$ Art. $4^{\circ}$. A súmula com efeito vinculante tem eficácia imediata, mas o Supremo Tribunal Federal, por decisão de $2 / 3$ (dois terços) dos seus membros, poderá restringir os efeitos vinculantes ou decidir que só tenha eficácia a partir de outro momento, tendo em vista razões de segurança jurídica ou de excepcional interesse público.
} 
O respeito da corte a seus próprios julgados e, simultaneamente, a possibilidade de ela revogar um seu precedente é conciliado por meio de técnicas e critérios rigorosos e especiais para revisão ou revogação do precedente. A corte superior, assim, ao criar um precedente, ao mesmo tempo em que obriga as cortes inferiores a observá-lo, cria para si uma espécie de auto-obrigação, consistente na observância, por ela própria, do precedente que estabeleceu.

Daí decorre a imprescindibilidade de que uma corte, qualquer corte, ao rever um seu entendimento anterior a respeito de uma dada matéria, se desincumba do ônus argumentativo que lhe toca de explicar todas razões que a levaram à mudança de posição. Sejam quais forem essas razões, o tribunal tem de reconhecê-las, explicitá-las, sob o indesejável risco de perder em credibilidade e de reduzir a confiança e a previsibilidade do modelo de precedentes. Mudar não é necessariamente ruim, claro, e pode significar justamente um aperfeiçoamento do direito. Mas a mudança impõe a quem muda, principalmente em um modelo precedentalista, o ônus de explicá-la, para que o movimento da mudança não brigue com a ideia de coerência. Em um leading case, as cortes já tem um dever incontornável de decidir com base em uma fundamentação diferenciada e qualificada, porque estarão não só a decidir o caso concreto mas também a estabelecer a ratio decidendi que será observada de modo vinculante pelos julgadores de inferior hierarquia. Se é assim nos leading cases, nos quais a liberdade do tribunal é maior porque ainda não há qualquer regra sobre o assunto, com muito mais razão é de se esperar uma maior cautela na decisão que revoga uma regra contida num precedente, porque aí a corte já tem uma baliza a ser observada, consistente justamente em seu próprio precedente.

Com isso se está afirmando que as impressões pessoais dos integrantes da corte sobre dado assunto, assim como eventuais pressões políticas, econômicas ou sociais que recaiam sobre o tema, são naturalmente reduzidas em um modelo de precedentes, notadamente quando se trata de overruling, no qual já existe uma regra a respeito do assunto. Como a corte tem de explicitar as razões pelas quais está a rever a regra, o que gera uma exposição, acaso a mudança esteja se dando por mera pressão ou por influência pessoal de um ou de outro de seus integrantes, o risco de redução de sua credibilidade 
existe e é grande, desestimulando atuações voluntaristas. Não se nega que em toda decisão judicial sempre haverá um espaço para as opiniões e tendências pessoais do julgador, mas com os precedentes tal espaço é mais restrito e mais controlado. ${ }^{75}$

Acima se disse que para a revogação de um entendimento é preciso que a regra vinda do precedente apresente incongruência social ou inconsistência sistêmica e que, além disso, não haja violação à segurança jurídica (tutela da confiança justificada e proibição de surpresas injustas) ou, se houver, que tal violação seja compensada pelas vantagens decorrentes da revogação do precedente. A esses fatores é possível acrescentar um outro, consistente na credibilidade e na respeitabilidade da corte como fator impeditivo de mudanças súbitas. Em um sistema precedentalista, reforça o dever de obediência aos precedentes a existência de um sentimento difuso e disseminado de que as cortes que os editam são sérias, consequentes e responsáveis e, por isso, merecem credibilidade e respeito. Desta forma, a mudança de entendimento, para além de poder abalar a isonomia, segurança jurídica e a previsibilidade, pode igualmente pôr em questionamento este sentimento existente relativamente aos tribunais, o qual é necessário em um modelo em que estes tribunais, interpretando as leis, criam regras gerais, abstratas e de cumprimento vinculante.

A existência de regras para a revogação de precedentes, a necessidade de que alguns requisitos estejam atendidos, a necessidade de a corte observar seus próprios precedentes, desenvolvendo uma fundamentação diferenciada quando quiser afastá-los e a preocupação que devem ter com sua própria respeitabilidade e credibilidade representam formas de controle a respeito da legitimidade das revogações de precedentes empreendidas pelos tribunais. Dessa afirmação decorre a conclusão de que a alterações na composição de uma corte não justifica, só por si, a alteração de um entendimento.

Quando os membros dos tribunais são indicados, não chegando a eles como uma fase normal de progressão na carreira da magistratura, é relativamente natural que aquele responsável pela indicação leve à corte alguém com posicionamentos que lhe agradem, por

\footnotetext{
75 “(...) o stare decisis atua como um elemento limitador da atuação das preferências pessoais dos magistrados e das pressões políticas sobre o processo decisório, muito embora não seja capaz de anulá-las" Patrícia Perrone Campos Mello, Precedentes - o desenvolvimento judicial do direito no constitucionalismo contemporâneo, p. 277).
} 
um motivo ou por outro. Mas indicações baseadas na tentativa de dar um perfil à corte (mais ou menos conservadora, mais ou menos garantista etc.) não podem gerar mudanças de precedentes sem observância dos critérios já existentes para tanto. Assim, apesar de o perfil e a linha ideológica predominante de uma corte servir como indicativo de como ela possivelmente decidirá nesta ou naquela questão nova (leading cases), deve ela permanecer observando os precedentes já existentes, ainda que, em decorrência da alteração na composição de seus membros, um dado entendimento já não mais represente a opinião da maioria. Isso porque no modelo precedentalista o direito não é apenas o entendimento da corte, mas igualmente é composto por razões de segurança jurídica. As pessoas e profissionais jurídicos que pautaram suas vidas e seus negócios com base em regras provenientes de precedentes regularmente estabelecidos não devem sofrer consequências negativas apenas porque ingressou no tribunal alguém que pensa diferente do que prevalecia até então. A análise dos precedentes deve ser feita na perspectiva institucional e não meramente individual. ${ }^{76}$

\subsection{Análise de casos concretos.}

Embora muitas vezes sem as discussões que se esperava em decisões que revogam precedentes, o fato é que no Brasil a mudança de entendimentos é algo comum, o que por um lado pode representar o fator positivo de que o direito tem evoluído e avançado, mas por outro traz a preocupação sobre a forma como estão sendo feitas tais mudanças, vale dizer, se elas estão ou não obedecendo padrões mínimos que lhe garantam legitimidade e asseguram os valores da isonomia, previsibilidade e segurança jurídica.

Por construção jurisprudencial, o TSE entendia que o prazo para ajuizamento de

\footnotetext{
${ }_{76}$ No julgamento do HC 96296/RS, $1^{\text {a }}$ T., Rel. Min. Marco Aurélio, unânime, j. em 11/5/2010, pub. DJE 4/6/2010, a Procuradoria-Geral da República suscitou preliminar de não cabimento do habeas corpus porque ele seria substitutivo do recurso ordinário em habeas corpus previsto na CRFB-1988 para as decisões de tribunal superior que denegam habeas corpus. O Ministro Marco Aurélio, relator, expressamente disse que concordava com a tese mas que o STF vinha admitindo a denominada impetração substitutiva do recurso ordinário. Lembrou que até já havia proposto a edição de súmula contendo o entendimento preconizado na preliminar suscitada mas a corte não aceitou. Em seguida, consignou que “(...) enquanto não houver alteração de jurisprudência, deve-se observar o que até aqui assentado, vale dizer, a possibilidade de, não tendo sido manuseado o recurso ordinário constitucional, o profissional da advocacia que acompanhou a impetração no Superior Tribunal de Justiça, ou mesmo aquele que não a tendo implementado, vir a impetrar, a qualquer tempo, o habeas substitutivo". Eis uma demonstração de como o modelo deve funcionar. Em que pese o entendimento individual do magistrado isoladamente considerado, a visão e a perspectiva devem ser sistêmicas, coletivas, institucionais, e não individuais nem voluntaristas.
} 
ação com base no art. 30-A da Lei 9.504/1997 era de 180 dias contados da diplomação do candidato. A Lei 12.034/2009 reduziu esse prazo para quinze dias, mantido o mesmo marco inicial. O TSE, então, passou a decidir que sua jurisprudência permanecia aplicável a todos os casos ajuizados até a entrada em vigor da Lei 12.034/2009, já que aqueles que confiaram no entendimento do TSE não poderiam ser prejudicados nem surpreendidos. Confira-se, por exemplo, o AgR-REspe 3857533-São Paulo/SP, Rel. Min. José Antônio Dias Toffoli, unânime, j. em 4/9/2012, pub. 17/9/2012, p. 24. Não é bem o caso de revogação de um precedente por outro, mas de revogação de um entendimento pela lei, tendo o tribunal levado em consideração questões ligadas à segurança jurídica para fins de deliberar os efeitos da lei em relação ao entendimento até então aplicável.

O STJ já validou decisão de corte inferior que decidiu conforme a jurisprudência do STJ que era a dominante quando a decisão foi proferida, ou seja, manteve a aplicação de jurisprudência que posteriormente veio a ser superada, em nome da segurança jurídica. No HC 121284/RJ, $5^{\mathrm{a}}$ T., Rel. Min. Napoleão Nunes Maia Filho, unânime, j. em 16/3/2010, pub. DJE 26/4/2010 foi dito que “(...) 1. A jurisprudência dos Tribunais Superiores aponta a prévia conclusão do procedimento administrativo fiscal como condição objetiva de punibilidade na ação penal; assim, não havendo a pré-apuração do crédito fiscal tido por fraudado, impõe-se declarar não haver crime a ser investigado e, menos ainda, denúnciacrime a ser apresentada. 2. Entretanto, este entendimento, hoje pacificado, já oscilou nos dois sentidos e, neste ponto, cumpre esclarecer que à época dos fatos e do oferecimento da denúncia, a solução então adotada pelo TRF da $2^{a}$ Região, de que o encerramento do processo administrativo era prescindível à propositura da ação penal, ainda prevalecia nas Cortes Superiores. 3. In casu, não configura constrangimento ilegal a execução de sentença penal condenatória, já transitada em julgado, porquanto à época do oferecimento da denúncia, a jurisprudência então dominante nas Cortes Superiores resguardava de legalidade a propositura da ação antes do lançamento definitivo do crédito tributário. 4. Ordem denegada, em conformidade com o parecer ministerial". No HC 166984/ES, 6 a T., Rel. Min. Og Fernandes, unânime, j. em 7/12/2010, pub. DJE 7/2/2011, o entendimento foi reafirmado, tendo restado decidido que “(...) 1. O entendimento desta Corte e do Supremo Tribunal Federal é no sentido de que a constituição definitiva do crédito pelo lançamento é condição necessária a validar a justa causa para o oferecimento da ação penal, nos crimes 
insertos no art. $1^{\text {o }}$ da Lei $\mathrm{n}^{\mathrm{o}} 8.137 / 90$. 2. Inexiste, todavia, constrangimento ilegal em execução de sentença penal condenatória, já transitada em julgado, quando, à época do oferecimento da denúncia, a jurisprudência então dominante nas Cortes Superiores resguardava de legalidade a propositura da ação antes do lançamento definitivo do crédito tributário. 3. Ordem denegada".

De fato, seria uma aparente incoerência o STJ reformar decisão que aplicou a jurisprudência então dominante do próprio STJ. O efeito das decisões que mudam jurisprudência, portanto, seria ex nunc, prospectivo e não retrospectivo. Observe-se que esse as duas decisões cuidam de matéria penal e eram prejudiciais ao réu.

Durante muito tempo, o STJ entendeu não haver crime na conduta daquele que, abordado por policiais, apresenta documentos falsos. Dizia-se que o fato era atípico, porque abrangido pelo exercício do direito constitucional à autodefesa. Contudo, no julgamento do HC 205666/SP, 6 a T., Rel. Des. convocado Vasco Della Giustina, unânime, j. em 23/8/2011, pub. DJE 8/9/2011, o STJ alterou seu posicionamento acerca do tema. O relator explicitou à corte que o entendimento até então era pela ausência de crime mas disse que discordava de tal posicionamento. Argumentou, basicamente, que a jurisprudência do STJ não se coadunava com os princípios e as finalidades do Direito Penal, porque (a) a conduta violava sim a fé pública e a credibilidade depositadas nos símbolos e instrumentos representativos, os quais precisam ser protegidos com rigor pelo Estado, haja vista a impossibilidade de se manter qualquer estrutura social, política e econômica em um ambiente de completa desconfiança, em que os signos ou os instrumentos de vontade não gozam de qualquer crédito perante os cidadãos e as instituições e (b) aquele que tem ciência de que está sendo procurado pela Justiça saberá que se portar um documento falso e o utilizar quando abordado por agentes do Estado, poderá se livrar da prisão, uma vez que é possível que obtenha êxito em enganar os policiais e, caso não alcance o desiderato ludibrioso, a sua conduta não será punida, visto que será tida como autodefesa, de modo que se mostra vantajoso a utilização de documento falso para aqueles que fazem do crime o seu modus vivendi, pois ter em mãos um instrumento de identificação inverídico só lhe trará benefício, nunca um prejuízo. 
Assim, o relator afirmou que o entendimento deveria ser afastado, quer porque a conduta de apresentar documento falso a agentes do Estado é lesiva ao bem jurídico fé pública, quer porque a jurisprudência até então prevalecente representava um estímulo à contrafação de documentos. Não foi feita nenhuma consideração a respeito de segurança jurídica, isto é, se havia algum motivo ligado à proteção da confiança justificada ou à prevenção de surpresas injustas que merecesse ser considerado antes de se deliberar pela realização ou não da mudança de entendimento ou que pudesse ensejar a aplicação de efeitos apenas prospectivos.

Embora seja difícil vislumbrar, em uma matéria desse tipo, algum tipo de confiança justificada digna de proteção ou surpresa injusta a ser proibida, o fato é que a revogação do entendimento anterior se deu sem nenhuma consideração a respeito das razões de segurança e autoridade do precedente (formal reasons), tendo considerado apenas as razões de justiça, isto é, os motivos para a correção em si do direito (substantive reasons). Apesar de no exemplo mencionado isso em princípio não ter acarretado nenhum problema concreto (porque é difícil se supor e aceitar que alguém contasse com a possibilidade de apresentar documentos falsos para autoridades), ainda assim merece destaque a prática de se revogar entendimentos sem atentar expressamente para valores tão caros a um modelo precedentalista.

Embora não cuidando de revogação de precedente, mas da solução de uma ação cível originária, isto é, uma demanda na qual funciona como primeira, única e última instância, o STF reconheceu a inconstitucionalidade de uma doação mas, por razões de segurança jurídica, expressamente não aplicou efeito nenhum à tal inconstitucionalidade, nem retroativos nem prospectivos.

Em 17 de junho de 1959, a União ajuizou uma ação cível originária no STF requerendo fosse reconhecida a nulidade da concessão do domínio de uma área de duzentos mil hectares feita pelo Estado de Mato Grosso a vinte empresas. Na ocasião, a União alegou violação ao $\S 2^{\circ}$ do art. 156 da Constituição do Brasil de 1946, a qual condicionava à prévia autorização do Senado a alienação ou concessão de terras públicas com mais de dez mil hectares. Pelo art. 188, $\S 1^{\circ}$, da Constituição da República de 1988, a 
área sujeita a prévia autorização foi reduzida para 2,5 mil hectares, sendo necessário também o pronunciamento da Câmara dos Deputados, além do Senado.

No julgamento, ocorrido quase 54 anos depois, em 15 de março de 2012, o relator, Ministro Cezar Peluso, reconheceu a inconstitucionalidade da alienação das terras, pela via de concessão de domínio, sem prévia autorização legislativa. No entanto, ele ponderou que a situação de fato da área se tornou irreversível, já que atualmente ela seria ocupada por cidades, casas, estradas, propriedades rurais, indústrias, estabelecimentos comerciais e de serviços, abrigando dezenas de milhares de pessoas. Por isso, mesmo reconhecendo a ilegalidade, propôs a convalidação da operação, invocando o princípio da segurança jurídica, até mesmo porque as terras foram repassadas pelo Estado a colonos, na presunção da boa-fé.

O Ministro Ricardo Lewandowski votou vencido, ao argumento de que uma decisão pela improcedência da ação representaria a legalização de latifúndios além das dimensões permitidas. Consignou que a área em questão envolve quarenta mil quilômetros quadrados, equivalente a duas vezes a extensão do Estado de Sergipe. Acrescentou que o Estado de Mato Grosso tem problemas com excesso de latifúndios e com questões ambientais e de fronteiras. Esclareceu que, apesar da situação já estar consolidada, caberia aos Estados de Mato Grosso e Mato Grosso do Sul resolver a situação jurídica decorrente da anulação dos atos de alienação. Foi acompanhando pelos Ministros Carlos Ayres Brito e Marco Aurélio mas o voto do relator findou prevalecendo.

Ao final, a ementa do acórdão deixou bem expressa a importância das questões ligadas à segurança jurídica e proteção da confiança e da boa-fé para o deslinde da causa:

"EMENTA: ATO ADMINISTRATIVO. Terras públicas estaduais. Concessão de domínio para fins de colonização. Área superiores a dez mil hectares. Falta de autorização prévia do Senado Federal. Ofensa ao art. 156, $\S 2^{\circ}$, da Constituição Federal de 1946, incidente à data dos negócios jurídicos translativos de domínio. Inconstitucionalidade reconhecida. Nulidade não pronunciada. Atos celebrados há 53 anos. Boa-fé e confiança legítima dos adquirentes de lotes. Colonização que implicou, ao longo do tempo, criação de 
cidades, fixação de famílias, construção de hospitais, estradas, aeroportos, residências, estabelecimentos comerciais, industriais e de serviços, etc.. Situação factual consolidada. Impossibilidade jurídica de anulação dos negócios, diante das consequências desastrosas que, do ponto de vista pessoal e socioeconômico, acarretaria. Aplicação dos princípios da segurança jurídica e da proteção à confiança legítima, como resultado da ponderação de valores constitucionais. Ação julgada improcedente, perante a singularidade do caso. Votos vencidos. Sob pena de ofensa aos princípios constitucionais da segurança jurídica e da proteção à confiança legítima, não podem ser anuladas, meio século depois, por falta de necessária autorização prévia do Legislativo, concessões de domínio de terras públicas, celebradas para fins de colonização, quando esta, sob absoluta boa-fé e convicção de validez dos negócios por parte dos adquirentes e sucessores, se consolidou, ao longo do tempo, com criação de cidades, fixação de famílias, construção de hospitais, estradas, aeroportos, residências, estabelecimentos comerciais, industriais e de serviços, etc." ${ }^{77}$

Na prática, a União viu acolhidos todos os seus argumentos, mas ainda assim seu pedido foi julgado improcedente. A análise deste julgado permite que se verifique a importância dada a segurança jurídica, que foi capaz até de convalidar ilegalidades e inconstitucionalidades. Não se teve aqui modulação de efeitos, mas a aplicação de nenhum efeito, ou seja, a afirmação peremptória de que a inconstitucionalidade e a ilegalidade não geraram nenhuma consequência. Diante da grande especificidade do caso, é difícil se extrair dele alguma ratio decidendi que, se houver, dirá respeito justamente a essa possibilidade de razões de segurança jurídica suplantarem razões de justiça.

Ainda sobre a relevância da modulação de efeitos, o STF julgou um caso que bem demonstra sua importância. O $\S 9^{\circ}$ do art. 62 da CRFB-1988, na redação dada pela Emenda Constitucional 32/2001, estabelece que “caberá à comissão mista de Deputados e Senadores examinar as medidas provisórias e sobre elas emitir parecer, antes de serem apreciadas, em sessão separada, pelo plenário de cada uma das Casas do Congresso Nacional". A esse respeito, o Congresso Nacional editou a Resolução 1/2002, estipulando o prazo de catorze dias para essa comissão mista apresentar parecer. Se ela não o fizesse nesse prazo, bastaria o parecer individual do relator designado.

\footnotetext{
${ }^{77}$ ACO 79/MT, Pleno, Rel. Min. Cezar Peluso, maioria, j. em 15/3/2012, pub. DJE 28/5/2012.
} 
A Medida Provisória 366/2007, que criou Instituto Chico Mendes de Conservação da Biodiversidade, foi convertida na Lei 11.516/2007, sem parecer da comissão mista mencionada no art. 62, $\S 9^{\circ}$, da CRFB-1988. Em decorrência disso, foi ajuizada a ação direta de inconstitucionalidade (ADI) 4029/AM. No dia 7 de março de 2012, a ação direta de inconstitucionalidade foi julgada parcialmente procedente, tendo sido reconhecida a violação do $\S 9^{\circ}$ do art. 62 da CRFB-1988. O relator, Ministro Luiz Fux, afirmou que a importância da comissão mista no processo de conversão de medidas provisórias decorria da necessidade, imposta pela Constituição, de assegurar uma reflexão mais detida sobre o ato normativo primário emanado pelo Executivo e que a existência efetiva da comissão garantiria que o Legislativo fiscalizaria o exercício atípico da função legiferante pelo Executivo.

Nesse primeiro momento, já fazendo uso da modulação de efeitos, o STF verificou não ser conveniente que o Instituto Chico Mendes de Conservação da Biodiversidade, criado pela lei inconstitucional, deixasse de funcionar. Por isso, disse que os efeitos da inconstitucionalidade só se aplicariam dali a 24 meses, prazo razoável para que o Poder Legislativo regularizasse a situação por meio da edição de lei que observasse o o correto rito constitucional.

Contudo, no dia seguinte, 8 de março de 2012, o Advogado Geral da União suscitou questão de ordem, lembrando ao STF que várias centenas de medidas provisórias tinham sido convertidas em lei sem observar o $\S 9^{\circ}$ do art. 62 da CRFB-1988, com base na Resolução 1/2002 do Congresso Nacional. Acrescentou que, com o entendimento que se estava a estabelecer, várias delas poderiam vir a ser questionadas no STF, gerando uma elevada insegurança jurídica. Em seguida, com base na advertência feita pelo Advogado Geral da União, o STF mudou sua conclusão na ADI 4029/AM. Se antes ela tinha sido julgada parcialmente procedente e os efeitos dessa parcial procedência incidiriam dali a 24 meses, agora ela foi julgada inteiramente improcedente, estabelecendo-se que somente as medidas provisórias editadas depois deste julgamento é que precisariam ter o parecer da comissão mista prevista no art. $62, \S 9^{\circ}$, da CRFB-1988..$^{78}$

\footnotetext{
${ }^{78}$ ADI 4029/AM, Pleno, Rel. Min. Luiz Fux, maioria, j. em 8/3/2012, pub. DJE 27/6/2012.
} 
Não se tem aqui efetivamente uma revogação de um precedente, mas uma demonstração segura da importância da segurança jurídica como forma de deflagrar uma decisão com efeitos apenas prospectivos. O STF, apesar de ter reconhecido uma inconstitucionalidade, percebeu existir a possibilidade de uma instabilidade normativa que seria causada pelo questionamento de centenas de medidas provisórias, e optou, conscientemente, pela alternativa de aplicar o vício de inconstitucionalidade somente para os casos futuros.

A legislação eleitoral proíbe a aposição de placas com dimensões superiores a $4 \mathrm{~m} 2$. No entanto, nas Eleições 2006, o TSE entendeu que a superação deste tamanho seria possível, desde que no comitê do candidato. Logo em seguida, o TSE voltou atrás, mudou seu posicionamento e passou a decidir que sob nenhuma hipótese seria possível o uso de placas com dimensões superiores a $4 \mathrm{~m} 2$.

Mesmo depois da mudança de entendimento, o TSE continuou a receber recursos eleitorais sobre essa matéria, vários deles ainda referentes às Eleições 2006. Para tais casos, o TSE decidiu ser necessário garantir aos candidatos condições idênticas de competição e, por isso, apenas para os casos relativos às Eleições 2006 seguia sendo aplicável o entendimento anterior, que permitia a veiculação de placa com tamanho superior a $4 \mathrm{~m} 2$ no comitê do candidato. A revogação do precedente, portanto, foi parcialmente prospectiva, porque ressalvou expressamente que determinadas hipóteses (as das Eleições 2006) permaneciam sendo regidas pela regra oriunda do precedente antigo, já revogado, tendo sido invocadas razões de isonomia e de previsibilidade. ${ }^{79}$

${ }^{79}$ RESPE 27696-São José do Rio Preto/SP, Rel. Min. Marcelo Henriques Ribeiro de Oliveira, unânime, j. em 4/12/2007, pub. DJ 1\%/2/2008, p. 36. 
PRECEDENTES NO SISTEMA JURÍDICO BRASILEIRO

6.1. A constante busca pela uniformização nas decisões. 6.2. Valorização crescente da jurisprudência. 6.3. A jurisprudência do próprio juizo. 6.4. O surgimento de julgamentos efetivamente vinculantes. 6.5. A súmula vinculante. 6.6. A repercussão geral. 6.7. O recurso especial repetitivo.

\subsection{A constante busca pela uniformização nas decisões.}

Embora tenha se intensificado mais recentemente, não é de hoje que o processo brasileiro se preocupa com a uniformização de decisões e dá importância à jurisprudência. Desde quando o Brasil não tinha efetivamente um direito próprio e se valia das normas vigentes em Portugal que a jurisprudência tinha relevância. $\mathrm{Na}$ ocasião, vigiam os chamados "assentos". As Ordenações Filipinas, em seu Livro I, Título V ("Dos Desembargadores da Casa da Suplicação"), $\S 5^{\circ}$, disponha que um colegiado de desembargadores, denominado "mesa grande", fixaria o entendimento a respeito de uma ordenação sobre a qual pairasse dúvida e tal entendimento teria de ser seguido, sob pena até de suspensão do juiz que o descumprisse.

No império, o Decreto 2.684, de 23 de Outubro de 1875, em seu art. $2^{\circ}$, preconizava que ao Supremo Tribunal de Justiça competia tomar assentos para inteligência das leis civis, comerciais e criminais quando na execução delas ocorressem dúvidas manifestadas por julgamentos divergentes havidos no próprio Supremo Tribunal de Justiça, nas Relações ou nos juízos de primeira instância, sendo que o entendimento deveria ser fixado por $2 / 3$ dos ministros da corte e era obrigatório até que fosse revogado pelo Poder Legislativo. Posteriormente, o Decreto 6.142, de 10 de Março de 1876, disciplinou de maneira mais detalhada a matéria, fixando critérios para a fixação de assentos. Estabeleceu-se, por exemplo, que o assento diria respeito apenas a questão de direito, e não a matéria fática (art. $2^{\circ}$ ), que eles não prejudicava a coisa julgada (art. $3^{\circ}$ ) e que era necessária uma exposição circunstanciada dos julgamentos divergentes (art. $\left.5^{\circ}, \mathrm{I}\right)$. 
Com o advento da República e a adoção da forma federativa de Estado, o $\S 2^{\circ}$ do art. 59 da Constituição de 1891 estatuiu que a justiça federal, nos casos em que houvesse de aplicar leis dos estados, consultaria a jurisprudência dos tribunais locais, e, de igual maneira, as justiças dos estados consultariam a jurisprudência dos tribunais federais quando tivessem de interpretar leis da União. O Decreto 848/1890, que disciplinava a Justiça Federal e como nela se daria o processo e julgamento das causas, previa expressamente que "os estatutos dos povos cultos e especialmente os que regem as relações jurídicas na República dos Estados Unidos da América do Norte, os casos de common law e equity, serão também subsidiários da jurisprudência e processo federal", naquilo que não contrariasse as "disposições e espírito" do decreto.

O Código de Processo Civil de 1939 previa o recurso de revista "nos casos em que divergirem, em suas decisões finais, duas ou mais câmaras, turmas ou grupos de câmaras, entre si, quanto ao modo de interpretar o direito em tese. Nos mesmos casos, será o recurso extensivo à decisão final de qualquer das câmaras, turmas ou grupos de câmaras, que contrariar outro julgado, também final, das câmaras cíveis reunidas".

Na redação originária do atual $\mathrm{CPC}$, restou previsto o instituto da uniformização de jurisprudência, consistente na fixação, pelo tribunal, previamente à decisão do caso concreto em si, de seu entendimento sobre uma questão de direito, sempre que for verificada a existência de divergência ou quando a decisão recorrida for divergente do entendimento que vem sendo adotado por órgãos fracionários do tribunal. O resultado do julgamento, o qual deve ser realizado pela maioria absoluta dos membros que integram o tribunal, será transformado em súmula e resolverá a questão jurídica, ao menos no respectivo tribunal (arts. 476 a 479 do CPC). Contudo, verificou-se, na prática, a pouca acolhida e consequente reduzida eficiência da uniformização de jurisprudência.

Esse histórico serve para demonstrar que é antiga a preocupação da legislação com a uniformidade de decisões e com o papel da jurisprudência na consecução deste fim. Em que pese seja o Brasil um país tradicionalmente filiado ao sistema do civil law, o primado da lei, assim como a independência funcional dos magistrados, não impediu nem 
reduziu a vontade do ordenamento de buscar a uniformização nas decisões. Esse dado é relevante, para que depois não se diga que a inquietação no Brasil com a falta de uniformidade é coisa recente.

\subsection{Valorização crescente da jurisprudência.}

Em 1963, ainda como consequência do prestígio que o Ministro Victor Nunes Leal dava às súmulas, o art. 15 , IV, do regimento interno do STF foi alterado para que nele fosse incluída a possibilidade de o relator poder mandar arquivar o recurso extraordinário ou o agravo de instrumento quando ele contrariasse a súmula, bastando a menção a seu número. Foi o primeiro reconhecimento do poder monocrático de decisão de relator. A possibilidade era limitada ao STF e a previsão não estava propriamente em lei, mas no regimento interno da corte, em um período no qual se entendia terem os regimentos internos dos tribunais a mesma hierarquia que a lei. O CPC de 1939, vigente na ocasião, não previa nada sobre o assunto.

Na redação original do Código de Processo Civil de 1973, a única hipótese de julgamento sozinho pelo relator estava prevista no caput do art. 557 e dizia respeito ao agravo de instrumento, o qual podia ser julgado monocraticamente se fosse "manifestamente improcedente", cabendo dessa decisão um recurso inominado para o órgão colegiado originalmente competente para a apreciação do agravo. Todos as outras hipóteses, em toda e qualquer espécie recursal, eram sempre necessariamente julgadas de maneira colegiada. Atente-se que o motivo pelo qual o recurso seria "manifestamente improcedente" poderia ser qualquer um, não necessariamente desrespeito a súmula ou à jurisprudência da corte. ${ }^{80}$

A primeira mudança nessa sistemática ocorreu com a Lei 8.038/1990, a qual instituía normas procedimentais para os processos no STJ e no STF. Seu art. 38 passou a permitir que o relator, no STJ ou no STF, pudesse apreciar monocraticamente o recurso que tivesse perdido seu objeto, além de poder negar seguimento a recurso manifestamente

\footnotetext{
${ }^{80}$ Art. 557. Se o agravo for manifestamente improcedente, o relator poderá indeferi-lo por despacho. Também por despacho poderá convertê-lo em diligência se estiver insuficientemente instruído.

Parágrafo único. Do despacho de indeferimento caberá recurso para o órgão a que competiria julgar o agravo.
} 
intempestivo, incabível, improcedente ou ainda, que contrariasse súmula do respectivo tribunal. $^{81}$

Observa-se que, no âmbito do STF e do STJ, a partir do art. 38 da Lei 8.038/1990, o relator passou a poder atuar sozinho relativamente ao controle dos pressupostos recursais e demais questões formais do recurso e também a poder "negar seguimento" não só ao recurso "improcedente" (hipótese já prevista na até então vigente redação originária do art. 557, caput, do CPC para o agravo de instrumento) mas também aos recursos que contrariassem súmula do respectivo tribunal. Cabe, aqui, uma consideração de ordem terminológica a respeito da expressão "negar seguimento". Na hipótese de recurso cuja tese jurídica de suas razões contraria súmula, o que se tem na verdade não é a pura e simples negativa de seguimento, costumeiramente ligada a questões formais, mas verdadeiro desprovimento do recurso, isto é, análise efetiva de seu mérito direta e exclusivamente pelo relator.

Além de autorizar a negativa de seguimento ao recurso por razões formais, o art. 38 da Lei 8.038/1990 permitia ao relator apenas julgar sozinho o desprovimento do recurso, não havendo permissão para ele, monocraticamente, prover o recurso, mesmo que a tese do recorrente fosse em tudo e por tudo acolhida em súmula do respectivo tribunal. A liberdade dada pela existência de súmula somente servia, portanto, para negar provimento a recursos, não para provê-los, por mais que tudo indicasse que o recurso seria provido por estar amparado em súmula. ${ }^{82}$ Uma possível explicação para isso está em que, ao desprover o recurso, o tribunal está na verdade mantendo a decisão recorrida, de modo que já se terá duas decisões com idêntico conteúdo, o que justificaria uma atuação isolada do relator. $\mathrm{O}$ argumento não é sólido, porque se a ideia é prestigiar e restabelecer a súmula da corte, isso

\footnotetext{
${ }^{81}$ Art. 38. O Relator, no Supremo Tribunal Federal ou no Superior Tribunal de Justiça, decidirá o pedido ou o recurso que haja perdido seu objeto, bem como negará seguimento a pedido ou recurso manifestamente intempestivo, incabível ou, improcedente ou ainda, que contrariar, nas questões predominantemente de direito, Súmula do respectivo Tribunal.

${ }^{82} \mathrm{O}$ art. $28, \S 2^{\circ}$, da Lei $8.038 / 1990$ permite que o relator, também monocraticamente, dê ou negue provimento ao agravo de instrumento manejado em face da decisão do tribunal recorrido que, realizando juízo de admissibilidade, denegou o recurso extraordinário ou o recurso especial. Esta hipótese, embora tenha sido a primeira a permitir o provimento de um recurso diretamente pelo relator, não é pertinente com a análise aqui feita, que cuida precisamente da ampliação dos poderes do relator como consequência do aumento da importância dada aos precedentes (jurisprudência dominante e súmulas). Neste caso, a possibilidade de julgamento monocrático pelo relator não depende da existência de precedentes. Ressalte-se que disposição semelhante à essa do art. $28, \S 2^{\circ}$, da Lei 8.038/1990 foi incluída no art. 544, § $2^{\circ}$, do Código de Processo Civil pela Lei 8.950/1994, posteriormente alterado pela Lei 10.352/2001.
} 
acontece quer quando a decisão recorrida a acompanhou (e o recurso almeja contrariar a súmula), quer quando a decisão recorrida negou aplicação à súmula (e o recurso quer justamente fazer prevalecer o entendimento contido na súmula).

A Lei 9.139/1995 alterou a redação original do caput do art. 557 do CPC para estender para todos os recursos o que até então estava restrito pela Lei 8.038/1990 aos recursos especial e extraordinário. ${ }^{83}$ A partir da alteração empreendida por aquela lei, em todo e qualquer recurso o relator passou a poder negar seguimento a recurso manifestamente inadmissível, improcedente, prejudicado ou contrário à súmula do respectivo tribunal ou de tribunal superior. A mudança aqui serviu para que mais tribunais (não só o $\mathrm{STJ}$ e o $\mathrm{STF}$ ) e mais recursos (não apenas o recurso especial e o recurso extraordinário) pudessem se valer da técnica de julgamento de maneira monocrática pelo relator nos casos em que a tese desenvolvida nas razões recursais contrariasse súmula. No entanto, o relator continuou impedido de, monocraticamente, dar provimento ao recurso. A exemplo do que já ocorria no sistema da Lei 8.038/1990, também a Lei 9.139/1995 alterou a redação original do art. 557, caput, do CPC somente para permitir o desprovimento do recurso por decisão singular do relator.

Entretanto, em 1998, a Lei 9.756 torna bem mais abrangentes os poderes do relator. Tanto na nova redação que ela deu ao caput do art. 557 como no $\S 1^{\mathrm{o}}$-A que lhe acrescentou, a importância dada à obediência às súmulas e aos precedentes foi realçada e ampliada. ${ }^{84}$ Com o advento da Lei 9.756/1998, não somente o julgamento de temas formalmente sumulados passam a poder ser feitos de modo monocrático pelo relator mas

\footnotetext{
${ }^{83}$ Art. 557. O relator negará seguimento a recurso manifestamente inadmissível, improcedente, prejudicado ou contrário à súmula do respectivo tribunal ou tribunal superior. (Redação dada pela Lei 9.139/1995)

Parágrafo único. Da decisão denegatória caberá agravo, no prazo de 5 (cinco) dias, ao órgão competente para o julgamento do recurso. Interposto o agravo a que se refere este parágrafo, o relator pedirá dia. (Redação dada pela Lei 9.139/1995)

${ }^{84}$ Art. 557. O relator negará seguimento a recurso manifestamente inadmissível, improcedente, prejudicado ou em confronto com súmula ou com jurisprudência dominante do respectivo tribunal, do Supremo Tribunal Federal, ou de Tribunal Superior. (Redação dada pela Lei 9.756/1998)

$\S 1^{\circ}$-A Se a decisão recorrida estiver em manifesto confronto com súmula ou com jurisprudência dominante do Supremo Tribunal Federal, ou de Tribunal Superior, o relator poderá dar provimento ao recurso. (Incluído pela Lei 9.756/1998)

$\S 1^{\circ} \mathrm{Da}$ decisão caberá agravo, no prazo de cinco dias, ao órgão competente para o julgamento do recurso, e, se não houver retratação, o relator apresentará o processo em mesa, proferindo voto; provido o agravo, o recurso terá seguimento. (Incluído pela Lei 9.756/1998)

$\S 2^{\circ}$ Quando manifestamente inadmissível ou infundado o agravo, o tribunal condenará o agravante a pagar ao agravado multa entre um e dez por cento do valor corrigido da causa, ficando a interposição de qualquer outro recurso condicionada ao depósito do respectivo valor. (Incluído pela pela Lei 9.756/1998)
} 
também aqueles em relação aos quais já há "jurisprudência dominante" do respectivo tribunal, do Supremo Tribunal Federal ou de Tribunal Superior.

Jurisprudência dominante deve ser considerada aquela objetivamente tida como cediça e tranquila no tribunal, ou seja, é dominante a jurisprudência quando a respeito do respectivo tema já tiverem sido julgado um significativo números de casos, preferencialmente com o enfrentamento expresso das várias teses existentes sobre o assunto. Só assim se poderá presumir a existência de uma estabilidade jurisprudencial hábil a permitir que o relator julgue o mérito do recurso monocraticamente, adiantando aquele que com alto grau de probabilidade seria ou será o julgamento do órgão colegiado. ${ }^{85}$ Conforme Luiz Guilherme Marinoni e Daniel Mitidiero, “jurisprudência pacífica é aquela que não encontra oposição séria dentro do tribunal em que formada. Normalmente acaba enunciada sob a forma de súmula. Jurisprudência dominante é aquela que predomina na orientação da Corte, ainda que exista uma outra orientação ponderável em sentido contrário". ${ }^{86}$

Além de, na redação dada ao art. 557, caput, do CPC pela Lei 9.756/1998, não ser mais necessário que a matéria esteja formalmente sumulada, bastando a existência de jurisprudência dominante, agora o relator também pode prover o recurso, quando antes podia apenas a ele negar provimento $\left(\S 1^{\mathrm{o}}\right.$-A do art. 557 do $\mathrm{CPC}$, incluído pela Lei 9.756/1998). Para tanto, é preciso que a decisão recorrida esteja em manifesto confronto com súmula ou com jurisprudência dominante do Supremo Tribunal Federal ou de Tribunal Superior. Vale aqui o mesmo reparo terminológico feito anteriormente sobre a "negar seguimento". Se as razões recursais contiverem tese jurídica confirmadora ou contrariadora de súmula ou de jurisprudência dominante, o que haverá é provimento ou improvimento do recurso e não mera negativa de seguimento, já que esta é relativa a questões formais e não à apreciação do mérito recursal.

Mas as mudanças promovidas pela Lei 9.756/1998 em matéria de recursos

\footnotetext{
${ }^{85}$ Por exemplo, o Superior Tribunal de Justiça já decidiu que não é "jurisprudência dominante" a autorizar o julgamento exclusivamente pelo relator a simples invocação de dois julgados monocráticos do Supremo Tribunal Federal a respeito do assunto em discussão (AgRg no REsp 707232/SP, Rel. Min. Arnaldo Esteves Lima, unânime, j. em 15/3/2007, pub. DJ 23/4/2007, p. 294).

${ }^{86}$ Luiz Guilherme Marinoni e Daniel Mitidiero, Código de Processo Civil comentado artigo por artigo, $\mathrm{p}$. 582.
} 
buscando prestigiar o respeito aos precedentes não foram só essas. Agora, depois das alterações empreendidas nos $\S \S 3^{\circ}$ e $4^{\circ}$ do art. 544 do CPC, no Superior Tribunal de Justiça e no Supremo Tribunal Federal, o relator do agravo de instrumento interposto em face de decisão que negou seguimento ao recurso especial ou ao recurso extraordinário pode, além de apreciar o agravo em si, na hipótese de lhe dar provimento, desde já julgar monocraticamente o mérito do próprio recurso especial ou extraordinário, se o acórdão recorrido estiver em confronto com súmula ou jurisprudência dominante.

Atente-se para o passo que foi dado: o relator do recurso especial ou extraordinário, apreciando um agravo de instrumento interposto em face de uma decisão que negou seguimento ao recurso por algum motivo, pode, sozinho, não só dar provimento ao agravo como também desde logo já julgar o mérito do respectivo recurso especial ou extraordinário, desde que presente a hipótese prevista de decisão em desconformidade com os precedentes consolidados ou sumulados.

Em 2001, o STJ editou a Súmula 251, deixando claro que "o art. 557 do CPC, que autoriza o relator a decidir o recurso, alcança o reexame necessário".

A transferência, para o relator, de poderes que o permitem julgar, monocraticamente e desde logo, o recurso tem razões pragmáticas que a justificam e legitimam, desde que os pressupostos exigidos pela legislação sejam devidamente observados. É que, já existindo jurisprudência dominante ou sumulada a respeito de determinado tema jurídico, não faz sentido que todo um órgão colegiado se reúna novamente para repetir algo que já dissera antes em várias outras ocasiões. É válida, portanto, a delegação dessa decisão para o relator. Obtém-se, assim, uma melhor divisão e administração da carga de trabalho, porquanto em relação aos temas jurisprudencialmente pacificados, em vez de poucos órgãos colegiados apreciando os respectivos casos, ter-se-á vários órgãos isolados do tribunal julgando a matéria, distribuindo a mesma justiça que seria distribuída se o julgamento fosse colegiado só que agora com observância do princípio da eficiência administrativa e também da duração razoável do processo (art. $5^{\circ}$, LXXVIII, da Constituição do Brasil de 1988). Abre-se, desse modo, a possibilidade para que os órgãos colegiados do tribunal, desonerados de apreciar novamente as mesmas teses 
que anteriormente já tinham analisado, possam apreciar com mais atenção temas e casos novos, aumentando a qualidade de suas decisões sem prejuízo da quantidade de casos julgados.

José Carlos Barbosa Moreira adverte ser preciso comedimento para não banalizar o conceito de "jurisprudência dominante", considerando como tal algo que não o é (pelo menos não ainda), cortando-se precocemente debate jurisprudencial eventualmente em curso. No entanto, observada tal advertência, o autor reconhece que

“é fácil de compreender (...) o enfado com que os tribunais encaram a necessidade de ocupar-se, pela enésima vez, de questões jurídicas cuja solução já se pacificou na crônica jurisprudencial. A própria exigência de racionalização do serviço recomenda que se coíba a reiteração ad infinitum de tentativas de ressuscitar, sem qualquer motivo sério, discussões mortas e enterradas. Não há vantagem prática em obrigar, por exemplo, o Supremo Tribunal Federal a gastar tempo e energias, que poderiam ser mais bem aproveitados, na incessante repetição de coisas ditas e reditas a propósito de um mesmo assunto". ${ }^{87}$

Além das razões pragmáticas, a possibilidade de julgamento do mérito recursal diretamente pelo relator se justifica por não ser ela uma técnica arbitrária. Observa-se, em todas as disposições que autorizam o julgamento do recurso monocraticamente pelo relator, a necessidade de demonstração da existência de precedentes específicos a respeito do tema objeto do recurso e, mais, é preciso que tais precedentes configurem uma jurisprudência resumida em súmula ou, ao menos, uma jurisprudência dominante. Existem, portanto, pressupostos específicos sem os quais o relator simplesmente não pode julgar sozinho e o atendimento a estes pressupostos legitimam a atuação singular do relator.

$\mathrm{Na}$ verdade, desde que fielmente observados os pressupostos legais previstos julgamento monocrático do mérito do recurso, com seu provimento ou improvimento, o relator nada mais faz do que adiantar aquele que provavelmente seria o julgamento do órgão colegiado. Ora, se o tribunal já tem jurisprudência dominante ou mesmo súmulas a respeito de determinada matéria e se o relator apenas aplica esses precedentes ao caso

\footnotetext{
${ }^{87}$ José Carlos Barbosa Moreira, Algumas inovações da Lei n. 9.756 em matéria de recursos civis, p. 76-77.
} 
concreto, julgando sozinho o recurso, na prática a parte recorrente está recebendo o mesmo julgamento que receberia se o recurso fosse apreciado pelo órgão colegiado. Não há, consequentemente, para ela, qualquer prejuízo.

No entanto, como é possível o erro do relator ou mesmo que ele julgue singularmente caso em que ausentes os pressupostos específicos que autorizam sua atuação monocrática, desbordando de seus poderes, é condição indispensável à legitimidade da previsão legal de julgamento de recurso isoladamente pelo relator a previsão de recurso em face da decisão monocrática. Com isso, permite-se à parte que eventualmente discordar do julgamento singular proferido a possibilidade de ver seu recurso julgado pelo órgão (necessariamente) colegiado originalmente competente para tanto e em nome de quem o relator supostamente agiu, por delegação. Por isso é que Nelson Nery Jr e Rosa Maria de Andrade Nery afirmam que a decisão do relator é provisória, sendo definitiva a do colegiado, se houver recurso. ${ }^{88}$

No Código de Processo Civil, tal recurso está previsto tanto no art. 545 quanto no art. 557, $\S 1^{\mathrm{o}}$, ambos do CPC, a depender da hipótese. O $\S 1^{\circ}$ do art. 557 do CPC fala que se o tribunal der provimento ao agravo (interposto em face de decisão monocrática do relator) "o recurso terá seguimento". No entanto, consoante já se mostrou, o caput do art. 557 e o $\S 1^{\circ}$-A do art. 557 do CPC também prevêem hipóteses de julgamento do próprio mérito do recurso (provimento ou improvimento). Para estas hipóteses, não há que se falar em ter o recurso seguimento, uma vez que o recurso já terá sido julgado. Ou seja: o trecho "o recurso terá seguimento" só se aplica para os casos de provimento do agravo movido em razão de decisão sobre matéria processual e não de mérito. A respeito do recurso para o órgão colegiado em face de decisão monocrática do relator escreveu José Carlos Barbosa Moreira que

“o 'juiz natural' do recurso é o órgão colegiado; não há bloquear totalmente o caminho até ele. Pode-se equiparar o papel do relator ao de um 'porta-voz avançado':o que ele diz, supõe-se que o diga 'antecipando' a decisão do colegiado. Ao interessado ressalva-se o direito de desencadear um mecanismo de controle, capaz de mostrar se a 'antecipação' correspondeu ou não ao entendimento 'antecipado'; em outras

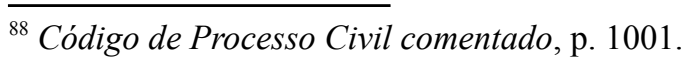


palavras, se merece realmente crédito o 'porta-voz'. ${ }^{89}$

O Supremo Tribunal Federal apresenta jurisprudência antiga, mas ainda corrente, indicando que o julgamento do mérito do recurso feito monocraticamente pelo relator não agride o princípio da colegialidade desde que haja recurso viabilizando à parte o controle da decisão singular pelo órgão colegiado. O que é proibido, portanto, é o relator ter incondicionalmente a decisão sozinha definitiva. Entende o STF que, podendo a decisão do relator ser contrastada via recurso, não há qualquer violação à colegialidade..$^{90}$

Verifica-se, pois, que, em matéria recursal, a ampliação dos poderes do relator está intimamente ligada ao prestígio crescente dado aos precedentes (inclusive os não sumulados) no Direito brasileiro. Ao comentarem o art. 557 do Código de Processo Civil, Luiz Guilherme Marinoni e Daniel Mitidiero chegam mesmo a dizer que "o relator tem o dever de julgar o recurso monocraticamente, preenchidos os requisitos inerentes à espécie, porque aí estará a prestigiar a autoridade do precedente e a patrocinar sensível economia processual"91 , texto que bem dá a dimensão da relevância adquirida pela jurisprudência dominante, mesmo sendo o Brasil um país historicamente ligado ao sistema do civil law.

Mas as mudanças não foram só essas. Em 2006, a Lei 11.276 incluiu no art. 518 do CPC um $\S 1^{\circ}$ segundo o qual “o juiz não receberá o recurso de apelação quando a sentença estiver em conformidade com súmula do Superior Tribunal de Justiça ou do Supremo Tribunal Federal". A súmula, que até então servia apenas para permitir o emprego

\footnotetext{
${ }^{89}$ José Carlos Barbosa Moreira, Algumas inovações da Lei n. 9.756 em matéria de recursos civis, p. 75-76.

${ }^{90}$ A respeito dos poderes processuais monocráticos concedidos aos relatores, o STF, no AgR na ADI 531/DF, Pleno, Rel. Min. Celso de Mello, unânime, j. em 11/12/1991, pub. DJ 3/4/1992, p. 4288, decidiu que o princípio da reserva de plenário não é abalado nem afastado na concessão de poderes processuais ao relator, desde que tal concessão nunca aconteça de maneira necessariamente definitiva. Vale dizer: é preciso que exista a possibilidade de a causa ser submetida ao órgão colegiado por meio de recurso contra a decisão monocrática, porque o julgamento por tribunais pressupõe a possibilidade de colegialidade. Assim, a recorribilidade da decisão singular é a condição para que a colegialidade inerente ao julgamento por tribunais não sofra violações e, consequentemente, para a validade e a legitimidade das decisões proferidas monocraticamente por julgadores de tribunais, sejam quais forem seus teores e conteúdos. Na ordem constitucional anterior já havia julgado que tinha chegado a conclusão semelhante (Rp 1299/GO, Rel. Min. Célio Borja, unânime, j. em 21/8/1986, pub. DJ 14/11/1986, p. 22148). Sobre o tema, podem ser consultados ainda os seguintes julgados: MI 375 AgR/PR, Pleno, Rel. Min. Carlos Velloso, unânime, j. em 19/12/1991, pub. DJ 15/5/1992, p. 6781, AgR no RE 156287/SP, 1 ${ }^{a}$ T., Rel. Min. Celso de Mello, unânime, j. em 30/11/1993, pub. DJ 20/5/1994, p. 12273; AgR no AI 742738/BA, 2a T., Rel. Min. Ellen Gracie, unânime, j. em 2/3/2010, pub. DJe 050, de 18/3/2010.

${ }^{91}$ Luiz Guilherme Marinoni e Daniel Mitidiero, Código de Processo Civil comentado artigo por artigo, $\mathrm{p}$. 581. Em sentido contrário, afirmando expressamente que é mera faculdade que a lei dá ao relator, que a exerce ou não, Nelson Nery Jr e Rosa Maria de Andrade Nery, Código de Processo Civil comentado, p. 1002.
} 
da técnica do julgamento monocrático mesmo em órgão colegiado, passou a servir como óbice à própria admissão do recurso de apelação. Trata-se da chamada súmula impeditiva de recurso. A seu respeito, e como a apelação pode cuidar também de matéria fática, Luiz Guilherme Marinoni e Daniel Mitidiero fazem importante advertência:

“(...) evidentemente, o não-recebimento da apelação com base no art. $518, \S 1^{\circ}$, do $\mathrm{CPC}$, pressupõe que a súmula do Superior Tribunal de Justiça ou do Supremo Tribunal Federal invocada na sentença outorgue solução ao problema jurídico levado pela parte a juízo. Vale dizer: a súmula deve constituir fundamento suficiente e determinante da decisão. Deve, por si só, dar sustentação à sentença. Se a súmula é apenas um dos argumentos utilizados na decisão, não se referindo ao cerne da controvérsia, não se está propriamente diante de sentença em conformidade com súmula, coo exigido pelo art. $518, \S 1^{\circ}, \mathrm{CPC}$. A consonância entre a sentença e a súmula deve ser tal que aponte para o óbvio improvimento de eventual recurso a ser interposto pela parte posteriormente ao Superior Tribunal de Justiça ou ao Supremo Tribunal Federal por já se encontrar a questão decidida na sentença pacificada no âmbito daqueles tribunais. Fora daí, o art. 518, $\S 1^{\circ}, \mathrm{CPC}$, não se aplica". ${ }^{92}$

A respeito da chamada súmula impeditiva de recursos prevista no art. 518, $\S 1^{\circ}$, do $\mathrm{CPC}$, há quem questione sua terminologia, já que a súmula, na verdade, não impede a apresentação do recurso, mas sim seu recebimento. Para alguns, o $\S 1^{\circ}$ do art. 518 do CPC tem, na verdade, mais uma função persuasiva do ato de não recorrer do que propriamente o de impedir em si o recurso. ${ }^{93}$

Na prática, quando a sentença estiver em conformidade com súmula do STJ ou do STF, isto é, quando as razões recursais da apelação buscarem contrariar entendimento sumulado destas duas cortes, o juiz de primeiro grau não deve sequer admitir a apelação. ${ }^{94}$ Em face desta decisão interlocutória que não admite a apelação, cabe agravo por instrumento, nos termos do art. 522, caput, do CPC, que autoriza o agravo por instrumento

\footnotetext{
${ }^{92}$ Luiz Guilherme Marinoni e Daniel Mitidiero, Código de Processo Civil comentado artigo por artigo, $\mathrm{p}$. 529-530.

${ }^{93}$ Esta, inclusive, aparente ser a opinião do Professor Antonio Carlos Marcato, externada em aula ministrada no curso de pós-graduação em Direito da Universidade de São Paulo.

${ }^{94}$ Para Rodolfo de Camargo Mancuso, como o art. $518, \S 1^{\circ}$, não se restringiu à súmula vinculante, mas tratou de qualquer súmula, ele é inconstitucional ( $A$ resolução dos conflitos e a função judicial no contemporâneo Estado de Direito, p. 588).
} 
para os casos de inadmissão da apelação. Só que, como a questão subjacente permanece sendo a contrariedade à súmula do STF ou do STJ, o relator deste agravo por instrumento no tribunal pode decidir monocraticamente, negando provimento ao agravo por estar ele em confronto com súmula do STF ou do STJ, com base no art. 557, caput, e no art. 527, I, ambos do CPC. A parte que recalcitrar contra a súmula do STF ou do STJ terá então de manejar mais um recurso, agora um agravo interno contra a decisão do relator que monocraticamente decidiu estar sendo o juízo de primeiro grau ao não admitir a apelação.

Seja como for, o fato é que se tem aqui mais uma demonstração clara da importância que se pretende dar aos julgados das cortes. Cada vez mais são elaboradas e aperfeiçoadas técnicas processuais que objetivam garantir suas autoridades, notadamente daqueles que consubstanciam jurisprudência dominante ou já foram resumidos em súmulas. Esse quadro representa uma aproximação gradativa, ou ao menos a obtenção de uma inspiração, no sistema do common law.

\subsection{A jurisprudência do próprio juízo.}

Do que se escreveu no item 6.2 acima é possível concluir que o respeito à jurisprudência consolidada sempre teve por base otimizar o trabalho dos tribunais, inicialmente o dos tribunais superiores (Lei 8.038/1990) e depois o dos demais tribunais. Mas o prestígio da jurisprudência foi além e criou uma técnica de julgamento mais acelerada também para os juízos de primeiro grau. Trata-se do art. 285-A, incluído no Código de Processo Civil pela Lei 11.277/2006 e conforme o qual quando a matéria controvertida for unicamente de direito e no juízo já houver sido proferida sentença de total improcedência em outros casos idênticos, poderá ser dispensada a citação e proferida sentença, reproduzindo-se o teor da anteriormente prolatada.

Sendo a matéria controvertida unicamente de direito, dispensa-se toda a tramitação de primeiro grau se no respectivo juízo já tiverem sido proferidas decisões de total improcedência em casos idênticos. É a improcedência prima facie. ${ }^{95}$ Neste caso,

\footnotetext{
${ }^{95}$ A improcedência prima facie de que cuida o art. 285-A do CPC não é a única. Também é possível a improcedência imediata quando a petição inicial for indeferida por prescrição ou decadência (arts. $219, \S 5^{\circ}$, 267, I, 269, IV, e 295, IV, todos do CPC) ou em caso de embargos à execução manifestamente protelatórios (art. 739, III, do CPC).
} 
apresentada a petição inicial e em seguida proferida sentença, haverá a citação do réu não para contestar, mas já para responder à apelação eventualmente interposta. O art. 285-A do $\mathrm{CPC}$ objetiva atender às mesmas finalidades das demais técnicas de julgamento baseadas na existência de jurisprudência dominante: não desperdiçar desnecessariamente tempo e recursos quando já se tem alta probabilidade a respeito de qual será o resultado do julgamento, ou seja, cuida-se de técnica de aceleração e meio de se estimular a observância de julgados anteriores. Mesmo assim, em texto escrito quando o art. 285-A ainda se encontrava na fase de processo legislativo, ou seja, ainda não estava inserto no CPC, José Carlos Barbosa Moreira fez ácidas críticas à previsão nele contida. Confira-se:

"Outro ponto digno de reparo é a autorização, que se pretende dar ao juiz, para sentenciar de plano, reproduzindo decisão anterior, quando já houver julgado improcedente o pedido em feito análogo. Aí não é sequer de prestigiar a jurisprudência que se trata: pressuposto bastante é a existência de um único precedente, do mesmo juízo. Dificilmente se concebe incentivo maior à preguiça, ou, em termos menos severos, ao comodismo do julgador, que poderá valer-se da franquia para desvencilhar-se rapidamente do estorvo de um novo processo, com a pura e simples baixa de um arquivo do computador. Dir-se-á que o texto projetado restringe a possibilidade às hipóteses em que não haja 'qualquer singularidade' na causa agora ajuizada; mas a lei do menor esforço quase fatalmente induzirá o juiz menos consciencioso a enxergar identidade onde talvez não exista mais que vaga semelhança. A tentação da facilidade será forte demais, sobretudo quando grande a carga de trabalho que estiver assoberbando o magistrado. Em não poucos casos, ante a primeira impressão do déja vu, a própria leitura da petição inicial corre o perigo de ver-se truncada, ou reduzida a sumária olhadela, desatenta a argumentos porventura novos que o autor suscite. Não se poderá contar muito, por parte do juiz, com o empenho - tão desejável - numa reflexão constantemente renovada sobre as questões de direito que lhe incumbe enfrentar". ${ }^{96}$

$\mathrm{O}$ art. 285-A do CPC cuida de técnica processual voltada à solução de demandas repetitivas. Ora, se naquele mesmo juízo já foram manejadas ações idênticas e elas, versando apenas matéria de direito, foram julgadas totalmente improcedentes, não há qualquer motivo para que a ação se repita à inteireza, porque seu resultado final é

\footnotetext{
${ }^{96}$ José Carlos Barbosa Moreira, Súmula, jurisprudência, precedente: uma escalada e seus riscos, p. 312.
} 
antecipadamente conhecido. ${ }^{97}$ Já se houver alguma questão de fato a ser resolvida, ou se a procedência nas sentenças anteriores foi apenas parcial, o art. 285-A do CPC não tem aplicação, porque vai ser preciso o desenvolvimento regular do processo para que sejam permitidas provas sobre a matéria de fato e/ou para que o réu se defenda, já que ao menos parte do pedido semelhante formulado em outras ações lhe foi desfavorável.

Discute-se se os julgados invocados pelo juízo de primeiro grau para poder repetir a sentença precisam ou não ter sido confirmados pelo tribunal. Inicialmente, é preciso que se tenha em conta que em todos esses casos nos quais a legislação permite um julgamento mais acelerado em razão da existência de jurisprudência predominante o que se pretende é a aplicação desde logo do direito já reconhecido, isto é, da tese. Estabelecida esta premissa, de nada adianta o juízo de primeiro grau julgar totalmente improcedente uma demanda com base em julgados seus se ele mesmo já sabe que tais decisões não serão mantidas porque estão em confronto com a tese predominante no tribunal ao qual está vinculado. $\mathrm{O}$ ideário por trás do instituto estaria completamente desvirtuado. O juízo de primeiro grau estaria usando julgados seus para julgar totalmente improcedente um pedido sendo que esta sentença provavelmente seria revertida em grau recursal, em razão da jurisprudência conhecida da corte que apreciaria a apelação. Com isso, o juiz estaria violando o principal motivo que levou a todas essas alterações legislativas, inclusive ao art. 285-A do CPC, que é o respeito pelos julgadores de hierarquia inferior dos entendimentos contidos nas decisões dos julgadores de hierarquia superior. Ademais, estaria havendo um prejuízo para a parte em favor de quem o entendimento da corte aproveita, forçando-a a ter de recorrer,

${ }^{97}$ Nelson Nery Jr e Rosa Maria de Andrade Nery dizem que em todo caso a ação tem de prosseguir normalmente, porque "o art. 285-A do CPC é inconstitucional, por ferir as garantias da isonomia (CF $5^{\circ}$, caput e I), do devido processo legal (CF $5^{\circ}$, caput e LIV), do direito de ação (CF $5^{\circ} \mathrm{XXXV}$ ) e do contraditório e ampla defesa $\left(\mathrm{CF} 5^{\circ} \mathrm{LV}\right)$, bem como o princípio dispositivo, entre outros fundamentos, porque o autor tem o direito de ver efetivada a citação do réu, que pode abrir mão de seu direito e submeter-se à pretensão, independentemente do precedente jurídico do juízo. Relativamente ao autor, o contraditório significa o direito de demandar e fazer-se ouvir, inclusive produzindo provas e argumentos jurídico e não pode ser cerceado nesse direito fundamental. De outro lado, o sistema constitucional não autoriza a existência de 'súmula vinculante' do juízo de primeiro grau, impeditiva da discussão do mérito de acordo com o due process (Código de Processo Civil comentado, p. 581 - grifos existentes no original). Em sentido parecido, Daniel Mitidiero atribui ao art. 285-A do CPC uma “(...) 'efetividade perniciosa', que se encontra em aberto conflito com os direitos fundamentais encartados em nosso formalismo processual. Com efeito, a pretexto de agilizar o andamento dos feitos, pretende o legislador sufocar o caráter dialético do processo, em que o diálogo judiciário, pautado pelos direitos fundamentais, propicia ambiente de excelência para reconstrução da ordem jurídica e conseguinte obtenção de decisões justas. Aniquila-se o contraditório, subtraindo-se das partes o poder de convencer o órgão jurisdicional do acerto de seus argumentos" [A multifuncionalidade do direito fundamental ao contraditório e a improcedência liminar (art. 285-A, CPC): resposta à crítica de José Tesheiner, p. 106]. 
em visível estímulo à litigiosidade..$^{98}$

Assim, se no juízo já houver sido proferida sentença de total improcedência em outros casos idênticos mas esta sentença não tiver sido confirmada e mantida pelo tribunal que a apreciou em grau recursal, desaparece a possibilidade de aplicação, neste caso, do art. 285-A do CPC..$^{99} \mathrm{O}$ julgado a ser respeito tem de ser sempre o do julgador de maior hierarquia, por razões de coerência sistêmica. Contudo, enquanto o tribunal não tiver apreciado a matéria, o juízo de primeiro grau pode seguir fazendo uso do art. 285-A do CPC porque aí ele não estará descumprindo julgado nenhum.

Registre-se que se a decisão do juízo de primeiro grau tiver por base súmula do STF ou do STJ, o recurso de apelação do autor vencido liminarmente sequer será recebido, agora com fundamento no art. $518, \S 1^{\circ}$, do CPC, já mencionado.

Tem-se, na improcedência liminar do art. 285-A do CPC, mais uma técnica processual de que o legislador lançou mão para (a) prestigiar entendimentos já existentes a respeito de um dado assunto, garantindo uniformidade de entendimentos e isonomia e (b) acelerar o julgamento de causas repetitivas, cujo objeto é matéria já enfrentada.

\subsection{O surgimento de julgamentos efetivamente vinculantes.}

Embora a técnica tenha sido criada para impedir ao máximo sua desobediência, o fato é que todas as hipóteses abordadas nos itens anteriores são de precedentes não vinculantes, ou seja, os julgados são meramente persuasivos, apesar, repita-se, de o sistema ter sido (na verdade, continua sendo) confeccionado para garantir que eles serão

\footnotetext{
98 "Se o juiz usa o art. 285-A do CPC em sentença que contraria o entendimento dos tribunais que lhe são superiores ele está, na verdade, negando o próprio espírito que levou à edição do dispositivo, que foi o da racionalização de processos repetitivos. Isso porque ele, em vez de beneficiar a parte a quem os precedentes dos tribunais favorecem, vai impor a ela uma derrota, cuja reversão vai custar à parte tempo e recursos, tudo com base em uma conviç̧ão sua a respeito do assunto que, por mais elogiável que seja, não é a prevalecente" (Eduardo Cambi, Neoconstitucionalismo e neoprocessualismo - direitos fundamentais, políticas públicas e protagonismo judiciário, p. 161).

${ }^{99}$ O STJ já decidiu que "deve ser afastada a aplicação do artigo 285-A do Código de Processo Civil quando o entendimento do juízo de primeira instância estiver em desconformidade com orientação pacífica de Tribunal Superior ou do Tribunal local a que se encontra vinculado". Cf. REsp 1109398/MS, 4a T., Rel. Min. Luis Felipe Salomão, unânime, j. em 16/6/2011, pub. Dje 1\%/8/2011 e REsp 1279570/MG, $2^{\mathrm{a}}$ T., Rel. Min. Mauro Campbell Marques, unânime, j. em 8/11/2011, pub. DJE 17/11/2011.
} 
observados.

Em todos os exemplos citados, os julgados, vale dizer, a jurisprudência consolidada, ou as súmulas, têm caráter apenas persuasivo e de acelerador do julgamento dos recursos. No entanto, mudanças recentes e gradativas no modelo constitucional e infraconstitucional vieram alterar esse quadro. Em pelo menos três novos institutos - a súmula de caráter vinculante, a análise da existência ou não de repercussão geral nos recursos extraordinários apresentados ao STF e o processamento dos recursos especiais repetitivos dirigidos ao $\mathrm{STJ}$ - o entendimento fixado em um caso anterior passou a ser, como no sistema da common law, de observância e cumprimento obrigatório em casos futuros que cuidem da mesma matéria. Tratam-se de inovações que demonstram estar o modelo jurídico romano-germânico (civil law) adotado no Brasil recebendo paulatinamente influências do modelo da common law. ${ }^{100}$

Porém, mesmo antes do surgimento desses três referidos institutos, a influência da common law já vinha sendo sentida no direito brasileiro. Em nível constitucional, desde a Emenda Constitucional 3/93, a qual incluiu o $\S 2^{\circ}$ no art. 102 da Constituição da República de 1988, as decisões definitivas de mérito proferidas pelo Supremo Tribunal Federal nas ações declaratórias de constitucionalidade de lei ou ato normativo federal produzem eficácia contra todos e efeito vinculante relativamente aos demais órgãos do Poder Judiciário e ao Poder Executivo. Precisamente quanto aos julgados proferidos neste tipo de ação, havia a expressa previsão de vinculação e de obediência dos demais órgãos do Poder Judiciário daquilo que restasse decidido.

Para Rodolfo de Camargo Mancuso, “(...) o dissenso sobre qual seja a melhor

\footnotetext{
100 “(...) Impõem-se um olhar renovado no tocante aos critérios de identificação do regime jurídico-político de um país, especialmente quanto à família jurídica a que ele se filia, porque o crescente intercâmbio internacional, a massificação das sociedades e o fenômeno da globalização não mais permitem um cômodo enquadramento num ou noutro dos tradicionais sistemas: o do direito escrito (civil law) e o do precedente judiciário (common law).

Isso porque os países daquele primeiro grupo, como o Brasil, em que pese a escolha da norma legal como parâmetro dos direitos e obrigações (CF/1988, art. $5^{\circ}$, II), vêm, desde o último quartel do século passado, exibindo crescente tendência receptiva aos precedentes judiciários (escalada que atingiu o ápice com o advento da súmula vinculante do STF: EC 45/2004), ao passo que países tradicionalmente filiados ao regime dos precedentes judiciários (binding precedents; stare decisis et non quieta movere) estão, em contrapartida, tendendo a valorizar cada vez mais o direito escrito: na Inglaterra, o Civil Evidence Act (1972) e, desde 1999, o Civil Procedure Rules; nos Estados Unidos, o Commercial Code, o Clean Air Act e o Federal Rules of Civil Procedure (Acesso à justiça-condicionantes legítimas e ilegítimas, p. 236).
} 
interpretação a ser extraída de um texto legal nada tem de excepcional na experiência jurídica, senão que, ao contrário, trata-se de ocorrência normal, imanente à própria natureza dialética do discurso jurídico (...)" ${ }^{101}$ Conforme o autor, a divergência a respeito do conteúdo de normas jurídicas é algo natural e até mesmo esperado, sendo consequência da atividade interpretativa e dos variados métodos hermenêuticos existentes, notadamente quando presentes hipóteses mais vagas, como quando se encontram na lei conceitos abertos ou indeterminados. A existência de julgados conflitantes não seria algo intrinsecamente ruim. Diz ele: “(...) a divergência jurisprudencial, em si mesma e contida em lindes razoáveis, não se constitui num problema ou num mal a ser reprimido, mas antes deve ser vista como uma virtualidade previsível, num sistema jurídico cujo parâmetro é precipuamente fornecido pela norma legal, que por definição é geral, abstrata $e$ impessoal" ${ }^{102}$ Assim, a divergência de entendimentos em um mesmo tribunal ou entre tribunais diversos é resultado da própria atividade interpretativa, sendo previsível e inevitável, tanto que o próprio sistema processual apresenta instrumentos voltados para os casos de divergência entre julgados, como os embargos infringentes, os embargos de divergência e o recurso especial por dissídio jurisprudencial.

No entanto, embora a existência de divergência jurisprudencial seja permitida e aceita, a técnica processual brasileira paulatinamente está incorporando hipóteses em que um julgado divergente de outro anterior simplesmente não subsiste, sendo cassado ou reformado às vezes de maneira automática, sem mesmo ser submetido a um órgão jurisdicional revisor. Vale dizer: há, hoje, no Brasil, situações em que um julgado dissonante de decisão do tribunal de hierarquia superior é revisto ou reformado com base precisamente nesta decisão e por aplicação de seus fundamentos sem sequer precisar ser apreciado pelo tribunal de superior hierarquia, autor da decisão. Repare-se que essa situação não se confunde com aquelas sobre as quais se discorreu no item X.2. Ali o tribunal faz valer seus precedentes de maneira mais rápida, mas o caso continua chegando até ele para ser analisado. Aqui se está a tratar de hipóteses em que o precedente do tribunal vai prevalecer de maneira obrigatória sem precisar chegar até ele para tanto.

\footnotetext{
${ }^{101}$ Rodolfo de Camargo Mancuso, Divergência jurisprudencial e súmula vinculante, p. 138.

${ }^{102}$ Rodolfo de Camargo Mancuso, Divergência jurisprudencial e súmula vinculante, p. 145.
} 


\subsection{A súmula vinculante.}

Veja-se o que ocorre com o instituto conhecido como súmula vinculante. Depois de muita controvérsia doutrinária, o legislador constituinte reformador, por meio da Emenda Constitucional 45/2004, incluiu na CRFB-1988 o art. 103-A, o qual trouxe para o ordenamento jurídico brasileiro o instituto da súmula de caráter vinculante, a ser editada pelo Supremo Tribunal Federal quando haja controvérsia atual entre órgãos judiciários ou entre esses e a administração pública a respeito da validade, interpretação ou da eficácia de normas determinadas, acarretando grave insegurança jurídica e relevante multiplicação de processos sobre questão idêntica (art. 103-A, caput e $\S 1^{\circ}$, da Carta Magna de 1988).

A Lei 11.407/2006 disciplinou a matéria em nível infraconstitucional. Além de cuidar do procedimento de edição, revisão e do cancelamento de enunciado de súmula com efeito vinculante, a Lei 11.407/2006 prevê, em seu art. $7^{\circ}$, o uso da reclamação para os casos de descumprimento da súmula. O STF, se acolher a reclamação e entendê-la procedente, anulará o ato administrativo ou cassará a decisão judicial impugnada, determinando que outra seja proferida com ou sem aplicação da súmula, conforme o caso.

Ao comentar a impressão de alguns segundo a qual a súmula vinculante representaria um divisor de águas no direito brasileiro, José Carlos Barbosa Moreira afirma que

"Essa impressão tende a desvanecer-se quando se olha mais de perto a realidade. Primeiro, porque mesmo no período anterior já era fortíssima, na prática judiciária, a propensão dos órgãos judiciais de primeiro e segundo grau a conformarse à jurisprudência dos tribunais mais altos - notadamente à do Supremo Tribunal Federal, e não apenas no campo delimitado pelo novo art. 103-A da Constituição (...). Se vier a ocorrer grande diferença prática, ela não resultará do comportamento de juízes e tribunais, mas do efeito inibitório a ser exercido pela 'súmula vinculante' sobre os órgãos da Administração Pública, obrigados a respeitar as proposições revestidas desse atributo, e em especial a abster-se de litigar em sentido contrário a elas". 103

${ }^{103}$ José Carlos Barbosa Moreira, Súmula, jurisprudência, precedente: uma escalada e seus riscos, p. 306307. 
De fato, como se viu no item 6.2, muito do que a súmula vinculante pode e pretende fazer já ocorria na prática, mesmo na ausência de súmula (basta a "jurisprudência dominante") e mesmo em casos de orientações jurisprudenciais não fixadas pelo Supremo Tribunal Federal (também pelos tribunais superiores ou pelo tribunal a cargo do julgamento do recurso). Contudo, há uma distinção. Em todos esses casos, mesmo com a existência do precedente, o processo ainda precisava chegar no STJ ou no STF para que fosse aplicado. Agora, como se verá, não. Um julgado do STJ ou do STF será obrigatoriamente aplicado sem que o processo lhe seja remetido para julgamento.

Com o advento da súmula de caráter vinculante, o ordenamento jurídico brasileiro passou a ter o seu primeiro caso em que a jurisprudência, desde que convertidos em súmula declarada como vinculante, são de observância obrigatória (o binding precedent do sistema da common law), afastando-se da eficácia apenas persuasiva (na common law, persuasive precedent). Na hipótese de desobediência à súmula vinculante (a qual, por sua vez, de acordo com o modelo constitucional, tem de se reportar à jurisprudência - "reiteradas decisões sobre matéria constitucional", diz o caput do art. 103-A do Texto Constitucional de 1988), cabe de imediato reclamação diretamente para o STF, o qual deve garantir a autoridade de suas decisões (art. 102, I, “l”, da Constituição do Brasil de 1988), inclusive as reveladas por meio de súmula vinculante. Aliás, essas, em razão de seu expresso caráter vinculante, talvez devam ter sua autoridade garantida até com maior intensidade.

Ou seja: descumprida a súmula, o $\mathrm{STF}$, acaso provocado por reclamação, pode imediata e diretamente anular o ato administrativo ou cassar a decisão que lhe desobedeceu, independentemente de outros recursos ou de outras considerações. Tem-se, pois, na súmula de caráter vinculante, a consolidação de uma jurisprudência tornada como de observância obrigatória, não havendo espaços para descumprimentos, exatamente como acontece no stare decisis do sistema da common law (embora lá sem a necessidade de uma imposição constitucional da vinculação). A reforçar essa proximidade, há ainda uma outra característica. O regime jurídico da súmula vinculante também admite arejamento e evolução. O dispositivo constitucional que criou a súmula vinculante previu expressamente a possibilidade de sua revisão ou de seu cancelamento (art. 103-A, caput e $\S 2^{\circ}$ ), assim 
como também o fez a legislação que regrou o procedimento de edição, revisão e cancelamento das súmulas vinculantes (Lei 11.417/2006). Vê-se aí uma nítida preocupação com a mudança e a evolução do direito, exatamente como acontece no modelo precedentalista típico.

No entanto, mesmo a existência de um instituto com declarado efeito vinculante ainda não é suficientemente completo para atender satisfatoriamente todas as situações. Veja-se o exemplo da Súmula Vinculante 11, que aparentemente não obedeceu aos requisitos que a CRFB-1988 exige para edição de uma súmula de caráter vinculante. ${ }^{104} \mathrm{~A}$ CRFB-1988 estabelece que a súmula vinculante poderá ser editada “após reiteradas decisões sobre matéria constitucional". A leitura dos apenas quatro julgados invocados antes da edição da Súmula Vinculante 11 mostra que em somente um deles algum tema constitucional foi debatido, a saber, o princípio da proporcionalidade. Nos outros três, a decisão se ateve a questões processuais penais, sem qualquer maior digressão sobre nenhum assunto de ordem constitucional. Esta seria uma primeira violação às regras de edição de súmulas vinculantes. Mas há outra.

A segunda parte do texto aprovado da Súmula Vinculante 11 preconiza quem o uso de algemas deve se dar da forma exposta na primeira parte, "sob pena de responsabilidade disciplinar, civil e penal do agente ou da autoridade e de nulidade da prisão ou do ato processual a que se refere, sem prejuízo da responsabilidade civil do Estado". Contudo, em rigorosamente nenhum dos julgados invocados como base para a edição da Súmula Vinculante 11 se tratou, sequer indiretamente, a respeito de questões ligadas à "responsabilidade disciplinar, civil e penal do agente ou da autoridade" nem de "nulidade da prisão ou do ato processual a que se refere" e, menos ainda, "da responsabilidade civil do Estado”. Ou seja, a súmula não apenas sumulou (resumiu) aquilo que já vinha sendo reiteradamente decidido pelo STF, mas inovou, indo bem além e estipulando uma espécie de "preceito secundário" para o descumprimento da súmula.

A Súmula Vinculante 11 e a forma como foi criada é mais um exemplo de que o

\footnotetext{
104 "Só é lícito o uso de algemas em caso de resistência e de fundado receio de fuga ou de perigo à integridade física própria ou alheia, por parte do preso ou de terceiros, justificada a excepcionalidade por escrito, sob pena de responsabilidade disciplinar civil e penal do agente ou da autoridade e de nulidade da prisão ou do ato processual a que se refere, sem prejuízo da responsabilidade civil do Estado".
} 
Brasil se ressente da falta de um verdadeiro modelo precedentalista. Até o STF, único tribunal que ainda tem algum poder expressamente reconhecido para proferir decisões vinculantes, em muitos casos precisa se esforçar e se contorcer para estabelecer um precedente vinculante que contemple a regra jurídica por ele entendida como a melhor e mais correta. Isso demonstra que o modelo brasileiro de julgados vinculantes precisa avançar ainda mais, para que efetivamente possa gozar de todas as vantagens que o modelo pode oferecer.

\subsection{A repercussão geral.}

Enquanto no caso de descumprimento de súmula vinculante cabe reclamação para que o STF diretamente determine seu cumprimento, uma situação ainda mais intensa ocorre com a repercussão geral, inovação trazida para o ordenamento jurídico pela inserção que a Emenda Constitucional 45/2004 fez do $\S 3^{\circ}$ do art. 103 da Constituição do Brasil de 1988. Regrando tal instituto, o art. 543-A, caput, do CPC, acrescentado pela Lei 11.418/2006, dispõe que o STF, em decisão irrecorrível, não conhecerá do recurso extraordinário, quando a questão constitucional nele versada não oferecer repercussão geral. Em seguida, os $\S \S 1^{\circ}$ e $3^{\circ}$ do art. 543-A do CPC esclarecem o que vem a ser repercussão geral, afirmando que sua verificação se dá pela análise a respeito da existência, ou não, de questões relevantes do ponto de vista econômico, político, social ou jurídico que ultrapassem os interesses subjetivos da causa, sendo que a repercussão geral é presumida pela lei sempre que o recurso extraordinário impugnar decisão contrária a súmula ou jurisprudência dominante do Tribunal.

Se em um determinado recurso extraordinário não for reconhecida a existência de repercussão geral, o $\S 5^{\circ}$ do art. 543-A do CPC estende esse precedente de ausência de repercussão geral a todos os outros recursos extraordinários que aportem ao STF e versem idêntica matéria, os quais serão indeferidos liminarmente. Para garantir que esses recursos extraordinários que tratam da mesma hipótese do caso em que, depois de efetiva apreciação, não foi reconhecida a existência de repercussão geral, o art. 327 do regimento interno do STF, expressamente autorizado pelo art. 543-A, $\S 5^{\circ}$, do CPC, estabelece que a presidência do tribunal ou, se esta não o tiver feito, o relator, podem liminar e 
monocraticamente recursar o recurso extraordinário.

Observa-se, pois, que o entendimento fixado a respeito da inexistência de repercussão geral em um dado recurso extraordinário pode se aplicar a diversos outros casos que posteriormente cheguem ao STF, os quais podem vir a sequer ser distribuídos, sendo liminarmente recusados pela presidência daquela corte por ausência de repercussão geral, conforme verificado no julgado anteriormente proferido a respeito do tema. A esse respeito, Bruno Dantas, comentando a decisão do STF que nega a existência de repercussão geral na questão constitucional trazida no recurso extraordinário, preconiza que “(...) essa decisão irradiará efeitos vinculantes sobre os recursos que se encontravam sobrestados na origem, e eles estarão automaticamente inadmitidos". ${ }^{105}$

Já se os tribunais ou as turmas de juizados especiais verificarem desde logo que há multiplicidade de recursos extraordinários com fundamento em idêntica controvérsia, o art. 543-B, $\S 1^{\circ}$, do CPC dispõe que caberá ao tribunal de origem selecionar um ou mais recursos extraordinários representativos da controvérsia e encaminhá-los ao STF, sobrestando os demais até o pronunciamento definitivo da corte. A hipótese difere daquela prevista no art. 543-A do CPC porque neste o precedente de inexistência de repercussão geral se aplica aos recursos extraordinários que chegam ao STF em um momento posterior, enquanto o art. 543-B do CPC trata dos casos em que desde já se sabe que muitos recursos extraordinários idênticos pendem de envio ao STF para julgamento.

Nestes casos (os do art. 543-B do CPC), somente os recursos extraordinários que tiverem sido selecionados pela corte de origem como representativos da controvérsia são remetidos ao STF. Além disso, o art. 328 do regimento interno do STF, diante da permissão que lhe deu o caput do art. 543-B do CPC, ampliou o controle dos recursos extraordinários que são enviados ao STF, ao prever que a presidência ou o relator, verificando que foi protocolado ou distribuído recurso cuja questão é suscetível de se reproduzir em múltiplos feitos, comunicará o fato aos tribunais ou turmas de juizado especial, a fim de que observem o disposto no art. 543-B do CPC e sobrestem todos os demais recursos extraordinários com questão idêntica. Tem-se aqui hipótese em que o próprio STF percebe que uma matéria objeto de dado recurso extraordinário pode se repetir em outros que ainda

\footnotetext{
${ }^{105}$ Bruno Dantas, Repercussão geral, p. 321.
} 
estão em tramitação na corte de origem e, antecipando-se às cortes de origem, determina o sobrestamento destes casos até o julgamento do recurso extraordinário que servirá de paradigma.

Mesmo se vários recursos extraordinários cuidando de questão idêntica entre si já tiverem sido enviados para o $\mathrm{STF}$, o parágrafo único do art. 328 do regimento interno do STF permite que a presidência do STF ou o relator selecione um ou mais recursos extraordinários representativos da controvérsia e determine a devolução dos demais aos tribunais ou turmas de juizado especial de origem, para aplicação do art. 543-B do CPC. O julgamento, portanto, é por amostragem.

Em todos esses casos, se for negada a existência de repercussão geral, os recursos sobrestados nos tribunais ou nas turmas de juizados especiais serão considerados automaticamente não admitidos (art. 543-B, $\S 2^{\circ}$, do CPC). Se for reconhecida a existência de repercussão geral e julgado o mérito do recurso extraordinário, os recursos sobrestados serão apreciados pelos tribunais ou turmas de juizado especial, os quais poderão declarálos prejudicados ou se retratar do julgamento proferido (art. 543-B, $\S 3^{\circ}$, do CPC). Acaso os tribunais ou turmas de juizado especial mantenham a decisão e admitam o recurso extraordinário, o STF pode cassar ou reformar, liminarmente, o acórdão contrário à orientação firmada no julgamento do recurso extraordinário paradigma.

A exemplo do que ocorre nos casos do art. 543-A do CPC, de acordo com o qual o precedente de inexistência de repercussão geral se aplica aos recursos extraordinários que chegam ao STF em um momento posterior, também nas hipóteses previstas no art. 543-B do CPC há extensão objetiva e subjetiva de um precedente para alcançar outros recursos extraordinários que até então estavam sobrestados, gerando (1) sua não admissão por ausência de repercussão geral, (2) a declaração, pelos tribunais ou turmas de juizado especial, de que estão prejudicados os recursos extraordinários até então sobrestados, porque o STF negou provimento ao recurso extraordinário representativo da controvérsia e confirmou o acórdão recorrido, (3) a retratação, pelos tribunais ou turmas de juizado especial, dos acórdãos que proferiram e que deram origem aos recursos extraordinários até então sobrestados, porque o recurso extraordinário representativo da controvérsia foi 
provido pelo STF e este entendimento deve ser observado, reformando-se o acórdão recorrido ou, por fim, (4) a manutenção, pelos tribunais ou turmas de juizado especial, dos acórdãos recorridos que proferiram e que até então se encontravam sobrestados, mesmo depois de haver sido provido pelo STF o recurso extraordinário paradigma representativo da controvérsia, hipótese em que os recursos extraordinários deixam de ficar sobrestados e devem ser enviados ao STF, o qual pode, inclusive liminarmente, cassar ou reformar o acórdão recorrido, já que ele não se coaduna com o precedente fixado por ocasião do julgamento do recurso extraordinário paradigma representativo da controvérsia.

Observe-se que, em alguma medida, o regime jurídico da vinculação ao julgado do STF em matéria de repercussão geral chega a ser mais amplo do que o regime jurídico da vinculação previsto para a súmula vinculante. Aqui a desobediência da súmula pela administração ou por algum órgão jurisdicional precisa ser levada ao conhecimento do STF por meio de reclamação e é este quem faz prevalecer seu próprio julgado Já nos casos de repercussão geral a lei determina que os próprios tribunais ou turmas de juizado especial apliquem - isto é, cumpram e façam cumprir - a decisão do STF. Não é o próprio órgão jurisdicional autor do julgado quem the restabelece em caso de descumprimento e sim outros órgãos que realizam concretamente o que foi decidido por aquele.

Vê-se aqui, de novo, duas espécies de decisão (tanto a que aprecia a existência ou não de repercussão geral quanto a que julga, por amostragem, o recurso extraordinário repetitivo) as quais, na prática, são obrigatórias e cumpridas de todo jeito, já que a sistemática processual prevista não abre espaço para que a decisão não seja observada, com se viu. Além disso, o conteúdo da decisão proferida nos casos selecionados se aplicam a outros casos que porventura surjam, ou seja, tem-se o que foi decidido em um leading case (com a particularidade de que aqui o leading case é escolhido) se estendendo a casos futuros, exatamente como ocorre em modelos precedentalistas tradicionais, nos quais a ratio decidendi do precedente é obrigatoriamente cumprida.

\subsection{O recurso especial repetitivo.}

Regime jurídico muito semelhante ao da repercussão geral nos recursos 
extraordinários apresentados ao STF se dá quanto ao processamento dos recursos especiais repetitivos dirigidos ao STJ. O art. 543-C do CPC, incluído pela Lei 11.672/2008, em caso de multiplicidade de recursos com fundamento em idêntica questão de direito, também autoriza que o tribunal de origem admita somente um ou mais recursos representativos da controvérsia para serem encaminhados ao STJ, ficando os demais recursos especiais suspensos até o pronunciamento definitivo do STJ. ${ }^{106}$ Quando sobrevier o julgamento, pelo STJ, do recurso especial paradigma, os demais recursos especiais que estavam sobrestados no tribunal de origem (1) terão seguimento denegado na hipótese de o acórdão recorrido coincidir com a orientação do STJ, (2) serão novamente examinados pelo tribunal de origem na hipótese de o acórdão recorrido divergir da orientação do STJ, podendo o tribunal de origem se retratar e fazer seu acórdão coincidir com o entendimento do STJ ou (3) se o tribunal de origem mantiver a decisão divergente, analisará a admissibilidade do recurso especial e, admitido este, o remeterá ao STJ.

De novo, como já se deu relativamente à apreciação da repercussão geral (arts. 543-A e 543-B do CPC), tem-se a extensão objetiva e subjetiva de um precedente para alcançar outros recursos especiais que até então estavam sobrestados, gerando (1) a negativa de seguimento aos recursos especiais, pelos tribunais de origem, porque o STJ negou provimento ao recurso especial representativo da controvérsia e confirmou o acórdão recorrido, (2) a retratação, pelos tribunais de origem, dos acórdãos que proferiram e que deram origem aos recursos especiais até então sobrestados, porque o recurso especial representativo da controvérsia foi provido pelo STJ e este entendimento deve ser observado, reformando-se o acórdão recorrido ou, ainda, (3) a manutenção, pelos tribunais de origem, dos acórdãos recorridos que proferiram e que até então se encontravam sobrestados, mesmo depois de haver sido provido pelo STJ o recurso especial paradigma representativo da controvérsia, hipótese em que os recursos especiais deixam de ficar sobrestados e devem ser enviados ao STJ, se receberem crivo positivo no juízo de admissibilidade.

\footnotetext{
${ }^{106}$ Teresa Arruda Alvim Wambier e Maria Lúcia Lins Conceição de Medeiros defendem ser cabível a suspensão de todos os processos que tratem da matéria que será decidida pelo STJ, independentemente da instância em que estejam, devendo aguardar a fixação da tese pelo STJ como forma de uniformização de entendimento (Recursos repetitivos - realização integral da finalidade do novo sistema impõe mais do que a paralisação dos recursos especiais que estão no $2^{\circ}$ grau, p. 192.
} 
$\mathrm{O}$ inciso II do $\S 7^{\circ}$ do art. 543-C do CPC estabelece que, uma vez publicado o acórdão proferido pelo STJ no julgamento do recurso especial escolhido como representativo da controvérsia (em técnica de julgamento por amostragem), os recursos especiais que ficaram sobrestados na origem aguardando a fixação da tese sobre a questão de direito pelo STJ serão, na hipótese de o acórdão recorrido divergir da orientação do STJ, "novamente examinados pelo tribunal de origem". Ou seja, se o acórdão do tribunal de origem em dado caso concreto anterior divergir, total ou parcialmente, do acórdão do STJ que, posteriormente, no recurso especial escolhido por amostragem, estabeleceu a tese sobre a matéria de direito, fica o tribunal de origem com o dever de reexaminar seu acórdão, agora já à luz do que decidido pelo STJ. Quer para manter o acórdão divergente daquilo que entendeu o STJ, quer para mudá-lo e encampar a tese fixada pelo STJ, o tribunal recorrido tem de efetivamente reanalisar seu próprio acórdão.

Alguns tribunais, em caso de acórdão divergente da tese estabelecida pelo STJ ao julgar o recurso especial representativo da controvérsia, estavam simplesmente, por despacho padrão, insistindo na divergência e remetendo ao STJ os recursos especiais até então sobrestados, sem proceder a uma concreta nova análise de seu próprio acórdão, para expor as razões pelas quais recalcitrava no acórdão anteriormente proferido, discrepante do entendimento do STJ. Por esse motivo, a Corte Especial do STJ, julgando questão de ordem nos recursos especiais n. 1.148.726/RS, 1.146.696/RS, 1.153.937/RS, 1.154.288/RS, 1.155 .480 e 1.158.872/RS, em todos sendo relator o ministro Aldir Passarinho Junior, decidiu que não ser possível ao tribunal de origem a mera confirmação automática de uma tese já rejeitada pelo STJ, sendo imprescindível uma nova apreciação fundamentada da matéria e, na hipótese de se persistir no entendimento oposto ao já uniformizado pelo STJ, a exposição da argumentação em contrário, rebatendo-se as razões da insistência na divergência. ${ }^{107}$

\footnotetext{
107 “A Corte Especial, considerando a resistência dos tribunais a quo à nova sistemática dos recursos repetitivos, embora sem ter caráter vinculante, subentendido, contudo, na sua ratio essendi, razão pela qual, forçosamente, está a carecer de uma complementação na legislação pertinente, acolheu em questão de ordem as propostas do Min. Aldir Passarinho Junior no sentido de restituir, por decisão de órgão fracionário desta Corte, independentemente de acórdão, decisão unipessoal de Min. Relator ou da Presidência, pelo Nupre, os recursos especiais à corte de origem para que sejam efetivamente apreciadas as apelações ou agravos como de direito, conforme a Lei n. 11.672/2008 e a Res. n. 8/2008-STJ. Ocorre, no momento, que os tribunais, sem reexaminar, por tira de julgamento, simplesmente o devolvem. Por isso, enfatizou o Min. Relator que não é possível fazer dessa forma, dispensando-se ementa, relatório e voto, para mandar novamente à Presidência, tendo ainda o advogado que fazer um requerimento para revalidar o recurso especial interposto e enviar ao STJ, o que, contrario sensu, equivale a julgar a mesma coisa com um adicional, frustrando o objetivo da lei
} 
De fato, ao se entender que o tribunal de origem tem o dever de, se quiser continuar divergindo do STJ, reanalisar seu acórdão, agora apreciando também as razões contidas no acórdão do STJ, está-se indo ao encontro da finalidade do instituto do recurso especial repetitivo, previsto no art. 543-C, do CPC, que é a de dar prevalência aos precedentes do STJ. ${ }^{108}$ Além disso, quando se exige que o tribunal de origem, para persistir no entendimento divergente, tem de motivar sua persistência, inclusive enfrentando os fundamentos do acórdão do STJ fixador da tese, contribui-se com a rediscussão do tema, permitindo-se, eventualmente, sua possível revisão, já que o STJ, ao apreciar o recurso especial apresentado em face do acórdão que fundamentadamente divergiu de sua tese mesmo depois de ela ter sido firmada, terá de rediscutir - seja para reafirmar, seja para rever - o próprio entendimento que estabeleceu no julgamento paradigma.

Mais que solucionar casos concretos, os recursos especiais submetidos ao regime do art. 543-C, do CPC tem uma finalidade pública e abstrata. A meta neles é, sobretudo, fixar qual é o entendimento do STJ para que os recursos especiais sobre a matéria não venham mais à corte. Tanto a finalidade é mais resolver a questão jurídica do que

do recurso repetitivo, qual seja, sistematização do trabalho do Judiciário. Nesse passo, ponderou que, no caso de interpretação restritiva, preferível que seja lavrado outro acórdão, feito um relatório para rebater objetivamente o que foi decidido nesta Corte, pois não faz sentido a hipótese de os tribunais a quo simplesmente não examinarem e, em apenas três linhas padronizadas, fazerem uma tira de julgamento, devolvendo o problema com a recalcitrância na tese. Assim, propõe, no caso, que quem estiver com um acórdão no gabinete devolva-o; se estiver pautado, devolva pautado sem acórdão; se for por decisão do Min. Relator, por despacho; se estiver no Nupre e se estiver na Presidência, por determinação da Presidência, pelo Nupre. Não se há de entender a mera confirmação automática de uma tese já rejeitada pela Corte nacional $a d$ quem, porém, minimamente, é preciso uma nova apreciação fundamentada da matéria, o que implica, na hipótes e de ainda se sufragar o entendimento oposto ao já uniformizado pelo STJ, a exposição da argumentação em contrário, rebatendo objetivamente as conclusões aqui firmadas. Com efeito, determinou o Min. Relator que se mande voltar para, efetivamente, ser reexaminado, não bastando o só repetir, deve-se rebater cada argumento do STJ. Outrossim, não cabe, por conseguinte, que uma resolução de tribunal de $2^{\circ}$ grau mude o CPC e altere a Lei n. 11.672/2008. Assim sendo, com a anuência do Min. Relator, ressaltou o Min. Teori Albino Zavascki a importância de sublinhar a inconstitucionalidade da resolução do tribunal, porquanto o art. 543-C do CPC é expresso, no $\S 8^{\circ}$, que o recurso seja novamente examinado, tendo-se uma nova decisão. No caso, considerou ser inconstitucional porque, pelo art. 93, IX, da CF/1988, todos os julgamentos dos órgãos do Poder Judiciário devem ser públicos e fundamentadas todas as decisões. Ora, a fundamentação necessariamente tem que haver, e, pela absoluta incompatibilidade com a CF/1988, opinou-se pelo acolhimento da QO nos termos como foi colocada, com a expedição de ofício aos presidentes dos tribunais regionais federais e tribunais de justiça sobre a decisão tomada na presente questão de ordem. QO nos REsp 1.148.726-RS, REsp 1.146.696-RS, REsp 1.153.937-RS, REsp 1.154.288-RS, REsp 1.155.480-RS e REsp 1.158.872-RS, Rel. Min. Aldir Passarinho Junior, julgada em 10/12/2009 (Informativo STJ n. 419 (7 a 11 de dezembro de 2009).

${ }^{108}$ Neste sentido, Teresa Arruda Alvim Wambier e Maria Lúcia Lins Conceição de Medeiros, Recursos repetitivos - realização integral da finalidade do novo sistema impõe mais do que a paralisação dos recursos especiais que estão no $2^{\circ}$ grau, p. 190. 
solucionar o caso concreto que o STJ, julgando uma questão de ordem no REsp 1063343/RS, decidiu não ser mais possível a desistência do recurso depois que ele foi selecionado com representativo da controvérsia. Independentemente das razões da desistência, o recurso deverá ser julgado, precisamente para que nele seja fixada a tese que servirá de paradigma para os demais casos. ${ }^{109}$

Observa-se, uma vez mais, um instituto voltado a criar uma regra que deverá ser observada em casos futuros. É mais uma aproximação do modelo processual brasileiro com o modelo de precedentes, mas ainda assim de modo insuficiente, com se verá.

\subsection{Controle de constitucionalidade e teoria dos motivos determinantes.}

No Brasil existem dois tipos de controle de constitucionalidade das leis e atos normativos. O concreto ou difuso é exercido por todo e qualquer juiz, em qualquer instância, nos casos concretos que lhe sejam submetidos. Tem por fundamento jurídico a supremacia da Constituição, a qual permite que qualquer lei ou ato normativo seja com ela contrastada para verificação de sua compatibilidade constitucional. Aqui a questão constitucional é apenas argumento, causa de pedir de uma das partes, dependendo a solução da demanda da apreciação prévia a respeito da constitucionalidade ou inconstitucionalidade da lei ou ato normativo. Não é o pedido principal. No controle difuso de constitucionalidade os efeitos do dispositivo da decisão somente se aplicam às partes do caso concreto em que ele foi proferido, somente se estendendo para terceiros se e quando o Senado fizer uso da prerrogativa prevista no art. 52, X, da Carta Política de 1988, que lhe dá a competência privativa para suspender a execução, no todo ou em parte, de lei declarada inconstitucional por decisão definitiva do Supremo Tribunal Federal. Tem-se aqui um caso como qualquer outro, apenas com a particularidade de nele se discutir a possível existência de uma inconstitucionalidade. Exatamente como em qualquer caso existente no sistema da common law.

A outra espécie de controle de constitucionalidade existente no Brasil é a abstrata ou concentrada, feita por órgãos com competência específica (embora não exclusiva) para

${ }^{109}$ REsp 1063343/RS, 2 ${ }^{a}$ Seção, Rel. Min. Nancy Andrighi, Rel. Min. João Otávio Noronha, maioria, j. em 12/8/2009, pub. DJE 16/11/2010. 
este fim (por exemplo, art. 102, I, “a”, e art. 125, § 2ª ambos da Constituição da República de 1988). Tem-se aí um processo de natureza objetiva, ou seja, desvinculado das partes nele envolvidas, no qual se busca apenas a apreciação da questão constitucional em si, ou seja, saber se a lei ou ato normativo é ou não constitucional. A declaração de constitucionalidade ou de inconstitucionalidade da lei ou ato normativo é o próprio pedido formulado ao órgão jurisdicional. Por força de dispositivo constitucional expresso, a decisão proferida no controle concentrado de constitucionalidade tem efeito vinculante relativamente a todos os demais órgãos do Poder Judiciário $\left(\S 2^{\circ}\right.$ do art. 103 da Constituição do Brasil de 1988). Assim, por exemplo, se o Supremo Tribunal Federal (STF), julgando improcedente uma ação direta de inconstitucionalidade, afirmar que o art. $1^{\circ}$ da lei estadual $\mathrm{X}$, o qual instituía uma vantagem em relação a um tributo estadual Y, é constitucional, os demais órgãos do Poder Judiciário que forem chamados a decidir a respeito daquele mesmo dispositivo específico, isto é, o art. $1^{\circ}$ da lei estadual $\mathrm{X}$, terão de obedecer o entendimento do STF de que o dispositivo é constitucional.

A questão que se põe é a seguinte: se, em um outro Estado, for editada uma lei estadual diversa com conteúdo rigorosamente idêntico, isto é, uma lei estadual $\mathrm{Z}$ instituindo a mesma vantagem em relação ao mesmo tributo estadual Y, estão os demais órgãos do Poder Judiciário obrigados a cumprir o que o STF havia decidido em relação à lei estadual $\mathrm{X}$ anteriormente mencionada? Não se cuida aqui de observar o que decidiu o STF apenas de modo facultativo, como mero argumento ou como forma de persuasão. $\mathrm{O}$ que importa é saber se os demais julgadores estão ou não obrigados a cumprir a decisão do STF proferida em caso que, embora idêntico, não dizia respeito à mesma lei.

Para se entender que os julgadores estão sim vinculados ao que decidiu o STF mesmo em um caso diverso, a respeito de lei distinta, vai ser preciso que se reconheça até mesmo nas decisões proferidas em controle abstrato e concentrado de constitucionalidade, ou seja, até no processo objetivo (e não somente o processo subjetivo, inter partes), a aptidão para gerar um precedente. De um caso (que não pode se chamar propriamente de concreto, porque é um controle abstrato de constitucionalidade) versando uma questão constitucional se estaria retirando uma regra geral e abstrata, exatamente como acontece no processo subjetivo (inter partes) tradicional. 
Acaso se admita que a decisão do STF que declarou constitucional a vantagem concedida pela lei estadual $\mathrm{X}$ em relação a um tributo estadual Y se aplica também à lei estadual Z, proveniente de um Estado diverso, vai ser preciso reconhecer que a decisão proferida no caso anterior tem um componente obrigatório que, indo além da pura e simples solução da hipótese concreta, se estende e se aplica também a um caso posterior semelhante. E isso é exatamente o conceito de ratio decidendi, isto é, verificar qual a regra usada invocada pelo juiz em sua decisão e estendê-la obrigatoriamente a casos futuros.

O STF apresenta julgados que contém uma discussão a respeito desse tema, embora feito sob outro enfoque, e que deve ser aqui analisada para que se demonstre a falta que faz um modelo efetivamente calcado em precedentes.

O $\S 2^{\circ}$ do art. 102 da Carta Política de 1988 estabelece que "as decisões definitivas de mérito proferidas pelo Supremo Tribunal Federal nas ações diretas de inconstitucionalidade e nas ações declaratórias de constitucionalidade produzirão eficácia contra todos e efeito vinculante relativamente aos demais órgãos do Poder Judiciário e à administração pública direta e indireta, nas esferas federal, estadual e municipal”. Vê-se que o dispositivo fala que o efeito vinculante é dado às "decisões", não a seus fundamentos. Mesmo assim, o STF apreciou casos nos quais se discutiu se os fundamentos de uma decisão definitiva proferida em ação direta de inconstitucionalidade ou em ação declaratória de constitucionalidade poderiam se estender e se aplicar também a outros casos semelhantes. O tema foi trazido da seguinte forma: uma decisão do STF em controle concentrado de constitucionalidade foi proferida em relação à lei X. Se alguém descumprir essa decisão em relação à lei X, cabe reclamação ao STF para garantia da autoridade de suas decisões (art. 102, I, “l”, da Carta Política de 1988). O problema era saber se a utilização de uma lei Y, com conteúdo idêntico ao da lei X, em sentido diverso daquilo que entendeu o STF (em relação à lei X), autoriza ou não o manejo de reclamação.

São dois os casos em que o tema foi discutido com mais detalhamento e é interessante abordá-los com mais detalhes para que se tenha uma maior compreensão do que foi debatido e decidido. 
No primeiro caso, em 2001, o STF, na ação direta de inconstitucionalidade (ADI) 1662/SP ${ }^{110}$, ajuizada pelo Governador do Estado de São Paulo, decidiu com base na redação que então tinha o $\S 2^{\circ}$ do art. 100 da Constituição da República de $1988^{111}$ que, na execução contra a fazenda pública por meio de precatórios, o sequestro da quantia necessária à satisfação do débito somente era cabível para a hipótese de preterição de seu direito de precedência e nenhum outro caso mais. Com isso, foi anulado um ato normativo do Tribunal Superior do Trabalho (TST) que, por equiparação, também considerava como preterição do direito de precedência a não inclusão no orçamento da verba necessária à satisfação de precatórios judiciais e o pagamento a menor, sem a devida atualização ou fora do prazo legal.

Posteriormente, o Tribunal Regional do Trabalho da $10^{\text {a }}$ Região (TRT-10), sem invocar o ato normativo do TST anteriormente declarado inconstitucional na ADI 1662/SP mas alegando que a Emenda Constitucional 30/2000 havia mudado o quadro normativo a respeito do assunto, determinou o sequestro de recursos do Distrito Federal em decorrência de ele não ter efetuado depósito para quitação de precatório trabalhista. O Governador do Distrito Federal, então, ajuizou a reclamação (Rcl) 1987/DF, alegando o descumprimento, pelo TRT-10, do que o STF tinha decidido na ADI 1662/SP, particularmente quanto a não ser cabível sequestro de valores para o caso de ausência de inclusão no orçamento da verba para pagamento de precatório.

Surgiu a questão sobre se o TRT-10, com sede no Distrito Federal, poderia descumprir uma decisão proferida em ação direta de inconstitucionalidade ajuizada pelo

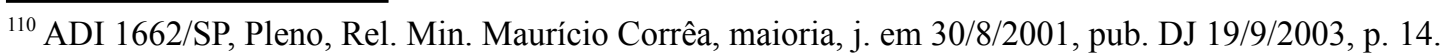

${ }^{111}$ Art. 100. À exceção dos créditos de natureza alimentícia, os pagamentos devidos pela Fazenda Federal, Estadual ou Municipal, em virtude de sentença judiciária, far-se-ão exclusivamente na ordem cronológica de apresentação dos precatórios e à conta dos créditos respectivos, proibida a designação de casos ou de pessoas nas dotações orçamentárias e nos créditos adicionais abertos para este fim.

$\S 1^{\circ}$ É obrigatória a inclusão, no orçamento das entidades de direito público, de verba necessária ao pagamento de seus débitos constantes de precatórios judiciários, apresentados até $1^{\circ}$ de julho, data em que terão atualizados seus valores, fazendo-se o pagamento até o final do exercício seguinte.

$\S 2^{\circ}$ As dotações orçamentárias e os créditos abertos serão consignados ao Poder Judiciário, recolhendo-se as importâncias respectivas à repartição competente, cabendo ao Presidente do Tribunal que proferir a decisão exeqüenda determinar o pagamento, segundo as possibilidades do depósito, e autorizar, a requerimento do credor e exclusivamente para o caso de preterimento de seu direito de precedência, o seqüestro da quantia necessária à satisfação do débito.

$(\ldots)$
} 
Governador do Estado de São Paulo contra ato normativo que nem foi invocado na decisão supostamente descumpridora. A depender da resposta, a reclamação sequer seria conhecida.

O Ministro Maurício Corrêa, relator, disse que a matéria era a mesma que já tinha sido julgada na ADI 1662/SP e que a Emenda Constitucional 30/2000 não tinha alterado nada a respeito do tema. Afirmou que na ADI 1662/SP o STF decidiu só caber sequestro quando houvesse preterição do direito de preferência e mais em nenhum outro caso, sendo que o tribunal expressamente havia dito não ser cabível reclamação para a não inclusão no orçamento de recursos para o pagamento do precatório. Em seguida, fez menção a ter existido o descumprimento do "conteúdo essencial" de uma decisão anteriormente proferida pelo STF na ADI 1662/SP, acrescentando que o efeito vinculante deve se estender a todos os casos em que posteriormente o tribunal se depare com textos normativos de "idêntica normatividade" ao texto cuja constitucionalidade já foi apreciada. Com base nisso, julgou procedente a reclamação para reconhecer que o TRT-10 descumpriu o entendimento da corte fixado na ADI 1662/SP.

No decorrer do julgamento, seguiram-se discussões, nas quais o Ministro Sepúlveda Pertence apresentou seu posicionamento contrário ao voto do relator, dizendo que o STF não podia transformar em súmula vinculante qualquer premissa de uma decisão e que o efeito vinculante não poderia se estender aos motivos da decisão, tendo recebido o apoio do Ministro Marco Aurélio, este alegando que a reclamação passaria a ser um instrumento para uniformização de jurisprudência. O Ministro Nelson Jobim dá a entender que concorda que os fundamentos da decisão devem se aplicar a todos os outros casos, porque é melhor resolver o problema logo via reclamação do que dez anos depois em recurso extraordinário, argumentando que os limites objetivos da coisa julgada clássicos previstos da legislação processual civil não se aplicariam às ações constitucionais. $\mathrm{O}$ Ministro Marco Aurélio realça que o art. 469 do Código de Processo Civil só estende a coisa julgada ao dispositivo e não aos fundamentos da decisão e que aspectos práticos não podem ser potencializados sem limites. Os Ministros Carlos Velloso e Celso de Mello acompanham o relator, embora sem maiores considerações específicas sobre a eficácia vinculante dos motivos determinantes da decisão. 
O Ministro Gilmar Mendes, então, trouxe expressamente para discussão colegiada na corte a questão sobre a extensão dos efeitos vinculantes, afirmando que ele não podia ficar limitado à parte dispositiva da decisão, devendo se estender também aos fundamentos dela. Invocou julgados do Tribunal Federal Alemão para em seguida acrescentar que a eficácia da decisão deveria transcender o caso singular, de modo que os princípios dimanados da parte dispositiva e dos fundamentos determinantes sobre a interpretação da Constituição deveriam ser observados por todos os juízes nos casos futuros. Existiria o que ele chamou de "norma decisória concreta", a qual seria uma ideia jurídica subjacente à formulação contida no dispositivo, que permitiria não só a decisão do caso concreto mas também a decisão de casos semelhantes. Argumentou que estender o efeito vinculante expressamente previsto na Constituição apenas para a parte dispositiva da decisão tornaria o instituto da vinculação desnecessário, porque ele teria basicamente o mesmo conteúdo da coisa julgada. Em seguida, citou vários casos em que ministros do STF, invocando decisões colegiadas que declararam inconstitucionais leis a respeito do IPTU de um dado município, julgaram monocraticamente recursos referentes a leis sobre IPTU de município diverso, por se tratar do mesmo fundamento jurídico. Com isso, pretendeu reforçar que a "aplicação dos fundamentos de um leading case em hipóteses semelhantes" para casos futuros era ínsita a um regime jurídico de efeito vinculante, como é o brasileiro em matéria de controle abstrato de constitucionalidade.

Ao final, por maioria, vencidos os Ministros Sepúlveda Pertence, Marco Aurélio e Carlos Ayres Britto, o STF acolheu a aplicação dos fundamentos da decisão proferida na ADI 1662/SP para outro caso a ela assemelhado. ${ }^{112}$

O segundo caso em que o STF discutiu em profundidade a teoria dos motivos

\footnotetext{
${ }^{112}$ Rcl 1987/DF, Pleno, Rel. Min. Maurício Corrêa, maioria, j. em 1\%/10/2003, pub. DJ 21/5/2004, p. 33. Na ementa do acórdão ficou consignado o seguinte: "admissibilidade da reclamação contra qualquer ato, administrativo ou judicial, que desafie a exegese constitucional consagrada pelo Supremo Tribunal Federal em sede de controle concentrado de constitucionalidade, ainda que a ofensa se dê de forma oblíqua". Há ainda um outro acórdão do STF em que a teoria dos motivos determinantes da decisão foi acolhida. Trata-se da Rcl 2363/PA, Pleno, Rel. Min. Gilmar Mendes, maioria, j. em 23/10/2003, pub. DJ 1a/4/2005, p. 7, em cuja ementa se registrou o seguinte: “(...) 5. Efeito vinculante das decisões proferidas em ação direta de inconstitucionalidade. 6. Eficácia que transcende o caso singular. 7. Alcance do efeito vinculante que não se limita à parte dispositiva da decisão. 8. Aplicação das razões determinantes da decisão proferida na ADI 1662 (...)". As demais decisões do STF acolhendo a teoria dos motivos determinantes são todas monocráticas.
} 
determinantes foi em 2010. ${ }^{113} \mathrm{O} \S 3^{\circ}$ do art. 100 da Constituição do Brasil de 1988, na redação que tinha quando foi incluído pela Emenda Constitucional 20/1998 (e que foi posteriormente alterada pela Emenda Constitucional 62/2009), previa que o regime tradicional de pagamentos das dívidas do poder público por meio de precatórios não se aplicava aos pagamentos que o poder público precisasse fazer em virtude de sentença judicial transitada em julgado quando o respectivo montante estivesse previsto em lei como obrigação de pequeno valor. $O \S 5^{\circ}$ do art. 100 preconizava que a lei que fixasse o montante que seria considerado pequeno valor poderia levar em consideração as diferentes capacidades financeiras das entidades de direito público. ${ }^{114}$

Com base nestes dispositivos, o Estado do Piauí editou a Lei Estadual 5.250/2002, prevendo que seriam considerados de pequeno valor os débitos de montante igual ou inferior a cinco salários mínimos.

Só que o art. 87 do Ato das Disposições Constitucionais Transitórias (ADCT) dispunha que, para efeito do $\S 3^{\circ}$ do art. 100 da Carta Política, até que acontecesse a publicação das respectivas leis definidoras pelos respectivos entes da Federação, seriam considerados de pequeno valor os débitos que tivesse valor igual ou inferior a quarenta salários-mínimos, para os Estados e o Distrito Federal, e trinta salários-mínimos, para os Municípios. ${ }^{115}$

\footnotetext{
${ }^{113}$ No julgamento do AgR na Rcl 2475/MG, Pleno, Rel. Min. Carlos Velloso, Red. p/ acórdão Min. Marco Aurélio, maioria, j. em 2/8/2007, pub. DJE 1\%/2/2008 o STF voltou a discutir colegiadamente o tema e não mais aceitou a teoria dos motivos determinantes, mudando o entendimento que havia estabelecido em 2003 quando julgou a Rcl 1987/DF a que já se fez referência. Mas, para fins de análise dos argumentos existentes a respeito do assunto, o caso de 2010 é mais completo, daí ter se optado por ele.

${ }_{114} \S 3^{\circ} \mathrm{O}$ disposto no caput deste artigo, relativamente à expedição de precatórios, não se aplica aos pagamentos de obrigações definidas em lei como de pequeno valor que a Fazenda Federal, Estadual ou Municipal deva fazer em virtude de sentença judicial transitada em julgado. (incluído pela Emenda Constitucional 20/1998)

$(\ldots)$

$\S 5^{\circ}$ A lei poderá fixar valores distintos para o fim previsto no $\S 3^{\circ}$ deste artigo, segundo as diferentes capacidades das entidades de direito público. (parágrafo incluído pela Emenda Constitucional 30/2000 e renumerado pela Emenda Constitucional 37/2002)

${ }^{115}$ Art. 87. Para efeito do que dispõem o $\S 3^{\circ}$ do art. 100 da Constituição Federal e o art. 78 deste Ato das Disposições Constitucionais Transitórias serão considerados de pequeno valor, até que se dê a publicação oficial das respectivas leis definidoras pelos entes da Federação, observado o disposto no $\S 4^{\circ}$ do art. 100 da Constituição Federal, os débitos ou obrigações consignados em precatório judiciário, que tenham valor igual ou inferior a: (incluído pela Emenda Constitucional 37/2002)

I - quarenta salários-mínimos, perante a Fazenda dos Estados e do Distrito Federal; (Incluído pela Emenda Constitucional 37/2002)

II - trinta salários-mínimos, perante a Fazenda dos Municípios. (Incluído pela Emenda Constitucional $37 / 2002)$
} 
Por conta disso, o Procurador-Geral da República ajuizou a ação direta de inconstitucionalidade (ADI) 2868/PI em face da Lei Estadual 5.250/2002, do Piaú́. Argumentou que as leis estaduais não podiam prever valor inferior a quarenta saláriosmínimos, nos termos do que previsto no art. 87 do ADCT.

O Supremo Tribunal Federal (STF), contudo, entendeu que o art. 87 do ADCT era apenas uma norma temporária e de transição, que somente se aplicava enquanto o respectivo ente político (Município, Estado ou Distrito Federal) não tivesse editado sua lei específica, prevendo o valor que lhe aprouvesse de acordo com sua capacidade financeira. A ADI 2868/PI foi julgada improcedente e a Lei Estadual 5.250/2002 do Piauí foi declarada constitucional e se entendeu que cabe ao ente político definir, de acordo com suas possibilidades, que montante seria considerado como de pequeno valor para fins de exceção ao regime de precatórios.

No mesmo ano, o Município de Indaiatuba-SP editou a Lei Municipal 4.233/2002, dispondo que seriam considerados de pequeno valor os débitos que não ultrapassassem $\mathrm{R} \$$ $3.000,00$ (três mil reais).

Apesar dessa lei municipal, o Tribunal Regional do Trabalho da $15^{\mathrm{a}}$ Região (TRT15) determinou em um mandado de segurança que o Município de Indaiatuba-SP adotasse as providências necessárias ao pagamento de $\mathrm{R} \$ 4.847,54$ (quatro mil oitocentos e quarenta e sete reais e cinquenta e quatro centavos), sob pena de sequestro.

O Município de Indaiatuba-SP, então, ajuizou no STF a Rcl (reclamação) 3014/SP ${ }^{116}$ alegando que o TRT-15 tinha descumprido a decisão do STF na ADI 2868/PI, porquanto aqui havia se decidido que os entes políticos têm liberdade para estipular os valores daquilo que pode ser considerado pequeno valor conforme suas capacidades financeiras.

Parágrafo único. Se o valor da execução ultrapassar o estabelecido neste artigo, o pagamento far-se-á, sempre, por meio de precatório, sendo facultada à parte exeqüente a renúncia ao crédito do valor excedente, para que possa optar pelo pagamento do saldo sem o precatório, da forma prevista no $\S 3^{\circ}$ do art. 100 . (Incluído pela Emenda Constitucional 37/2002)

${ }^{116}$ Rcl 3014/SP, Pleno, Rel. Min. Ayres Britto, maioria, j. em 10/3/2010, pub. DJE 21/5/2010. 
O relator da Rcl 3014/SP, Ministro Carlos Ayres Britto, julgou improcedente a reclamação porque o TRT-15 não estava descumprindo a decisão proferida na ADI 2868/PI, já que esta havia cuidado da Lei Estadual 5.250/2002, do Piauí, e não da Lei Municipal 4.233/2002, do Município de Indaiatuba-SP.

No entanto, em seu voto vista, o Ministro Gilmar Mendes, lembrando a evolução da reclamação constitucional como ação constitucional voltada à garantia da autoridade das decisões e da competência da corte e de sua importância como instrumento apto a proteger a ordem constitucional como um todo, propôs que o STF, no próprio bojo de reclamações, analisasse a constitucionalidade de leis cujo teor é idêntico, ou mesmo semelhante, a outras leis que já foram objeto do controle concentrado de constitucionalidade pelo STF. No caso específico da Rcl 3014/SP, analisar-se-ia a constitucionalidade ou não da Lei Municipal 4.233/2002, do Município de Indaiatuba-SP mesmo sem esse ser o pedido. Por mais de uma vez, o Ministro Gilmar Mendes fez um esforço de argumentação para dizer que não se estaria transcendendo para a Rcl 3014/SP os motivos que foram determinantes para o julgamento da ADI 2868/PI. Para ele, tratar-se-ia apenas do exercício de um poder ínsito à própria competência do STF de físcalizar incidentalmente a constitucionalidade das leis e dos atos normativos, poder que seria realçado quando a corte se deparasse com leis de teor idêntico a outras já submetidas a seu crivo no âmbito do controle abstrato de constitucionalidade. Afirmou ele claramente que, ainda quando não fosse caso de reclamação, poderia ser fazer uso desta ação para requerer a declaração incidental de constitucionalidade ou de inconstitucionalidade de lei ou ato normativo idêntico a outro que já tinha sido apreciado pelo STF em controle abstrato de constitucionalidade. Concluiu dizendo que divergia do relator e, diante do que já havia sido decidido pelo STF na ADI 2868/PI, a Rcl 3014/SP deveria ser conhecida e julgada procedente para declarar a constitucionalidade da Lei Municipal 4.233/2002, do Município de Indaiatuba-SP. Acrescentou que essa solução tinha um inegável efeito prático, tornando desnecessário o ajuizamento de uma ação direta de inconstitucionalidade ou de uma ação declaratória de constitucionalidade somente para o STF apreciar uma lei ou ato normativo igual a outro cuja constitucionalidade já havia sido apreciada. 
O Ministro Cezar Peluso acompanhou o posicionamento do Ministro Gilmar Mendes defendendo que, independentemente da teoria dos motivos determinantes, se uma norma passou pelo controle abstrato de constitucionalidade e foi tida por constitucional ou inconstitucional, já não precisa mais passar por novo controle abstrato, por força do efeito vinculante, o qual se estenderia à norma em si, independentemente da lei ou do ato normativo em que ela estivesse contida. A renovação da discussão seria desnecessária. Objetado pelo Ministro Carlos Ayres Britto se isso não seria transcendência dos motivos, respondeu que não, que era apenas o reconhecimento da forma da decisão que afirmou ser a norma constitucional ou não.

Seguiram-se, então, algumas discussões sobre as benesses práticas que poderiam advir da aceitação da reclamação como forma de apreciar a constitucionalidade de uma lei ou ato normativo idêntico a outro já analisado anteriormente. Mencionou-se que para as partes o ganho de tempo e de redução de dificuldades seria enorme e que para o próprio STF também seria bom, porque apesar do possível aumento no número de reclamações, o volume de trabalho decorrente da quantidade de recursos extraordinários seria diminuído, com a vantagem de que o resultado viria muito mais rapidamente e sem precisar ocupar os tribunais intermediários com ações custosas e demoradas as quais desembocariam em recursos extraordinários. O Ministro Gilmar Mendes, inclusive, sugeriu que era apenas um troca: a questão chegaria mais rapidamente, via reclamação, ou dez anos depois, por recurso extraordinário. Mencionou-se que a admissão da reclamação para este fim, permitindo ao STF resolver rapidamente a questão, impede que uma eventual norma inconstitucional produza efeitos por um longo tempo, o que muitas vezes dificulta seu desfazimento do ponto de vista prático.

A Ministra Cármen Lúcia se mostrou preocupada com a guinada jurisprudencial que a corte estava a dar, realçando que a um só tempo se estava a admitir um controle incidental de lei municipal feito diretamente no STF, ou seja, em princípio o controle nem seria incidental, porque seria concentrado no STF por meio do ajuizamento de reclamação, e estaria sendo feito em face de lei municipal, para o que o STF a rigor não tem competência. Afirmou ser simpática à tese proposta pelo Ministro Gilmar Mendes mas disse que, por ora, acompanharia o relator. 
O Ministro Sepúlveda Pertence demonstrou inquietação com o fato de se estar suprimindo instâncias (“estamos à beira de acabar com outras instâncias", disse), tendo o Ministro Carlos Ayres Britto acrescido que a ideia, apesar de interessante, era concentradora e feita per saltum.

Depois de ter pedido vista dos autos, o Ministro Ricardo Lewandowski trouxe voto afirmando ter se preocupado com a proposta de uso da reclamação como instrumento de controle de constitucionalidade de leis municipais. Depois, disse que de fato o tema discutido na Rcl 3014/SP realmente era o mesmo que já tinha sido objeto da ADI 2868/PI e que concordava com a proposta do Ministro Gilmar Mendes, para evitar que um mesmo tema voltasse a ser debatido pelo STF um sem número de vezes e também pelos aspectos práticos provenientes da medida. Alegou ser mais econômico e eficaz do ponto de vista processual discutir a matéria já em reclamação do que esperar por seu exame em recurso extraordinário cujo resultado já é sabido, o que causaria desnecessária sobrecarga ao sistema judiciário.

Em continuação, o Ministro Marco Aurélio consignou ser preocupante esse abertura no uso da reclamação, inclusive com queima de etapas. A Ministra Ellen Gracie foi mais contundente e disse que o uso da reclamação tal como estava sendo proposto seria uma ampliação indevida e sem previsão constitucional da competência do STF, ainda que para proferir uma decisão carimbada. Lembrou que a declaração de constitucionalidade ou inconstitucionalidade exige quórum qualificado, enquanto que o julgamento da reclamação, não. Além disso, haveria uma ampliação dos legitimados a realizar controle de constitucionalidade, já que, em tese, a reclamação pode ser ajuizada por qualquer pessoa interessada, enquanto os legitimados para propositura de ações direta de constitucionalidade ou ação declaratória de constitucionalidade integram um rol taxativo. Os argumentos ligados às supostas vantagens de ordem prática foram por ela refutados com a repercussão geral, que teria sido criada justamente para essas causas repetitivas e multitudinárias. O Ministro Gilmar Mendes rebate a suficiência do uso da repercussão geral dizendo que esperar a repercussão geral significa deixar a causa tramitar por tribunais de origem e tribunais superiores para só então chegar no STF, com desgaste para todos. 
Em nova rodada de debates, o Ministro Cezar Peluso invocou o direito norteamericano para dizer que nos Estados Unidos da América a Suprema Corte não retira a lei do ordenamento jurídico. O que é a retirada de uma norma. A autoridade da decisão recai sobre a tese jurídica que afasta uma norma - e não o texto que a contém - do ordenamento. A Ministra Ellen Gracie discorda e diz expressamente que o sistema brasileiro é diverso e que os fundamentos não vinculam, recebendo o endosso do Ministro Carlos Ayres Britto, o qual afirma que o sistema americano é o de precedentes, diversamente do brasileiro.

Alguns ministros, então, discutiram sobre se tinha ou não havido descumprimento do que tinha sido decidido na ADI 2868/PI. A Ministra Ellen Gracie e o Ministro Marco Aurélio dizem abertamente que não, enquanto os Ministros Cezar Peluso e Ricardo Lewandowski insistem que sim. A Ministra Ellen Gracie acrescenta que o STF já julgou diversas ações diretas de inconstitucionalidade e declaratórias de constitucionalidade e que, se os motivos das decisões aí proferidas forem determinantes e vinculantes, ensejando-se com isso reclamações, o impacto prático seria péssimo para o STF, que receberia uma quantidade imensa de processos.

Já se aproximando o fim do julgamento, o Ministro Eros Grau afirmou que texto e norma são institutos distintos e que norma é o produto da interpretação do texto. Com base nisso, acompanhou a divergência inaugurada pelo Ministro Gilmar Mendes e até aqui seguida pelos Ministros Cezar Peluso e Ricardo Lewandowski. O Ministro Joaquim Barbosa lembrou que o modelo de precedentes nos países da common law foi desenvolvido ao longo de séculos e que o Brasil precisa ter cautela. A Ministra Ellen Gracie reforça que se há como o entendimento do STF ser aplicado por meio da via processual ordinária, não é cabível a reclamação, notadamente porque a reclamação não é o instrumento adequado para realizar controle de constitucionalidade, sob o risco de subverter todo o regime jurídico deste controle, notadamente quanto a seus legitimados e seu objeto. Lembrou que aceitar a reclamação como meio de controlar a constitucionalidade representaria quase uma avocatória, já que a causa deixaria de ser julgada pelos órgãos originalmente previstos para ser solucionada de logo pelo STF. 
Ao final, foram vencidos os Ministros Gilmar Mendes, Cezar Peluso, Ricardo Lewandowski, Eros Grau e Celso de Mello e, por 6 X 5, prevaleceu a tese do relator, Ministro Carlos Ayres Britto, o qual foi acompanhado pelos Ministros Sepúlveda Pertence, Cármen Lúcia, Marco Aurélio, Joaquim Barbosa e Ellen Gracie. O STF não aplicou a teoria dos motivos determinantes, não vislumbrou descumprimento do que havia sido decidido na ADI 2868/PI e julgou improcedente a reclamação. ${ }^{117}$

A partir dessa análise descritiva feita desses dois julgamentos do STF se pode observar que, acaso algumas premissas advindas do modelo precedentalista fossem adotadas ou tivessem ao menos sido cogitadas, as discussões e soluções poderiam ter tomado outro rumo.

Conforme já se disse oportunamente (capítulo 3), ratio decidendi é a porção de uma decisão cujo cumprimento é obrigatório por decisões posteriores que venham apreciar casos semelhantes. Trata-se a ratio decidendi da regra jurídica usada pelo julgador expressamente ou não - para decidir o caso anterior, a qual, justamente por poder se tornar geral e abstrata, se desprende do caso concreto em que foi proferida e passa a poder ser repetida em casos idênticos ou parecidos. Para que se chegue a esta regra, são observados elementos como o pedido apresentado pela parte, os fatos considerados importantes pela decisão, além da própria decisão proferida, inclusive sua fundamentação e seu dispositivo. Vê-se, pois, que ratio decidendi não se confunde com a fundamentação da decisão, nem com seu dispositivo, embora deles não prescinda para que seja encontrada.

\footnotetext{
${ }^{117}$ Desde o julgamento do AgR na Rcl 2475/MG, Pleno, Rel. Min. Carlos Velloso, Red. p/ acórdão Min. Marco Aurélio, maioria, j. em 2/8/2007, pub. DJE 1\%/2/2008 que o STF não adotava mais a teoria dos motivos determinantes, entendimento prevalecente até hoje, conforme se verifica nos julgados seguintes, todos contrários à ideia de aplicar a um caso posterior os fundamentos de um caso anterior: AgR na Rcl 2475/MG, Pleno, Rel. Min. Carlos Velloso, Red. p/ acórdão Min. Marco Aurélio, maioria, j. em 2/8/2007, pub. DJE 1\%/2/2008 (com discussão sobre o tema); AgR na Rcl 2990/RN, Pleno, Rel. Min. Sepúlveda Pertence, unânime, j. em 16/8/2007, pub. DJE 14/9/2007; AgR na Rcl 5389/PA, $1^{\text {a }}$ T., Rel. Min. Cármen Lúcia, unânime, j. em 20/11/2007, pub. DJE 19/12/2007; AgR na Rcl 4448/RS, Pleno, Rel. Min. Ricardo Lewandowski, unânime, j. em 25/6/2008, pub. DJE 8/8/2008; AgR na Rcl 5703/SP, Pleno, Rel. Min. Cármen Lúcia, unânime, j. em 16/9/2009, pub. DJE 16/10/2009; Rcl 3014/SP, Pleno, Rel. Min. Ayres Britto, maioria, j. em 10/3/2010, pub. DJE 21/5/2010 (com discussão sobre o tema); AgR na Rcl 6204/AL, Pleno, Rel. Min. Eros Grau, unânime, j. em 6/5/2010, pub. DJE 28/5/2010; AgR na Rcl 6319/SC, Pleno, Rel. Min. Eros Grau, unânime, j. em 17/6/2010, pub. DJE 6/8/2010; AgR na Rcl 3385/RN, Pleno, Rel. Min. Dias Toffoli, unânime, j. em 1a/8/2011, pub. DJE 8/9/2011; AgR na Rcl 9778/RJ, Pleno, Rel. Min. Ricardo Lewandowski, unânime, j. em 26/10/2011, pub. DJE 11/11/2011; AgR na Rcl 11478/CE, $1^{\text {a }}$ T., Rel. Min. Marco Aurélio, unânime, j. em 5/6/2012, pub. DJE 21/6/2012; AgR na Rcl 5216/PA, Pleno, Rel. Min. Cármen Lúcia, unânime, j. em 13/6/2012, pub. DJE 19/9/2012.
} 
Nas decisões do STF cujo resumo se fez anteriormente, o problema consistia em saber se os fundamentos usados em determinada decisão para declarar constitucional ou inconstitucional a lei ou ato normativo $X$ se aplicariam ou não em relação a uma lei ou ato normativo Y, nominalmente diverso, editada por órgão distinto, mas de conteúdo idêntico ao daquele já apreciado pelo STF. Ao discutir sobre a chamada teoria dos motivos determinantes da decisão e, com isso, ao refletir sobre se os motivos que levaram o tribunal a decidir de um jeito em relação à lei $\mathrm{X}$ se estenderiam vinculativamente à lei $\mathrm{Y}$ o que o STF estava a fazer nada mais era do que discutir sobre se a ratio decidendi do caso da lei $\mathrm{X}$ (caso anterior) se aplicaria ou não de maneira obrigatória ao caso da lei Y (caso posterior). Verifica-se nos votos proferidos e nas discussões existentes que a premissa de semelhança entre os casos estava presente em todas as perspectivas. Embora os pedidos e, consequentemente, os dispositivos (fatores a serem considerados na determinação da ratio decidendi) fossem formalmente distintos (um referente à lei $\mathrm{X}$ e o outro à lei $\mathrm{Y}$ ), na prática, em substância cuidava-se da mesma coisa, já que os atos normativos eram materialmente bem assemelhados ou idênticos.

De fato, conforme afirmado por alguns ministros, não faz sentido que o STF, para fins de verificar eventual descumprimento de sua decisão em relação à lei X, admita o uso da reclamação e, em relação à lei $\mathrm{Y}$, de conteúdo idêntico ou substancialmente assemelhado ao da lei $X$, não se permita o uso da reclamação. O argumento de que o STF já tinha decisão específica a respeito da lei X e não a tinha a respeito da lei Y não serve para justificar a diferença de tratamento. É que, na prática, em essência, a corte já tinha sim uma decisão sobre a lei Y. Como a lei Y é idêntica ou substancialmente assemelhada ao da lei $X$, na verdade o posicionamento do STF a respeito dela será rigorosamente o mesmo entendimento existente sobre a lei X. Assim, para aplicar o entendimento já fixado pelo corte segundo o qual “em caso de precatório, só cabe sequestro dos valores necessários à satisfação do débito somente é cabível na hipótese de preterição do direito de precedência e nenhum outro caso mais" ou que "cabe ao ente político definir, de acordo com suas possibilidades, o montante a ser considerado como de pequeno valor para fins de exceção ao regime de precatórios" deve ser cabível o mesmo instrumento processual, independentemente de o possível descumprimento a este posicionamento estar sendo feito por meio da lei X ou da lei Y. O critério, então, para decidir pelo cabimento ou não da 
reclamação deveria ser "existência de descumprimento de precedente do STF" (precedente aí considerando em seu sentido correto, como sinônimo de ratio decidendi) e não apenas “existência de descumprimento de decisão específica e precisa do STF”. Aliás, o art. 102, I, “l”, da Constituição da República de 1988 diz caber reclamação ao STF para garantia da autoridade de suas decisões e não apenas "de suas decisões". Não seria necessário muito esforço hermenêutico para conseguir incluir nessa expressão garantir a "autoridade" das decisões qualquer descumprimento de precedente, e não apenas de dispositivos.

Ao adotar um entendimento restritivo de que só cabe reclamação nas hipóteses de descumprimento do dispositivo específico contido na decisão em ação direta de inconstitucionalidade ou na ação declaratória de constitucionalidade, e não o de que cabe sempre que a regra jurídica geral e abstrata (ratio decidendi) fixada pelo tribunal for desobedecida, o STF estimulou o descumprimento de seus entendimentos e, em consequência, deu uma contribuição imensa para o aumento quantitativo de litígios, bem como para a demora em seus deslindes. Se tivesse tomado para si a responsabilidade de processar e julgar todas as reclamações que alegassem descumprimento das ratio decidendi de seus julgados em controle concentrado de constitucionalidade o STF enviaria a mensagem para as demais cortes e juízes para que estivessem atentos e não desobedecessem suas decisões, além de assumir a responsabilidade de ser o principal responsável pela fixação da extensão da ratio decidendi de seus próprios julgados, ou seja, as questões tradicionalmente complexas sobre a abertura, extensão, generalidade seriam resolvidas pela própria corte autora do precedente. Não tendo aceito a reclamação com essa necessária abrangência, as partes em favor de quem um dado precedente do STF surgido em controle concentrado de constitucionalidade aproveitasse foram enviadas aos procedimentos tradicionais, que ocupam tempo e dinheiro não só das partes mas também dos juízes de primeiro grau, dos tribunais de apelação, eventualmente do Superior Tribunal de Justiça e, enfim, do STF, via recurso extraordinário.

A alegação de que a abrangência na admissão da reclamação acarretaria um aumento no seu número aparentemente se confirmaria, mas na prática a esse aumento no número de reclamações corresponderia a uma diminuição no número de recursos extraordinários, ou seja, aconteceria incremento no volume de uma classe de processos 
mas diminuição em outra, com a vantagem de que a solução seria muito mais expedita. Ademais disso, uma das consequências práticas vindas do sistema precedentalista é a possibilidade de se julgar causas repetidas e já decididas de uma maneira muito mais pragmática, com decisões sucintas que apenas demonstram a similitude dos casos anterior e posterior e aplica a regra geral e abstrata contida no precedente, ou seja, à ampliação do número de reclamações não corresponderia necessariamente um aumento na quantidade de trabalho, por conta da possibilidade de uso dessas técnicas.

Outra das objeções apresentadas à encampação da teoria dos motivos determinantes - que nada mais é do que a aplicação de conceitos ligados à fixação de ratio decidendi - consistia no fato de o art. 102, § $2^{\circ}$, da Carta Política de 1988 só prever o efeito vinculante para a decisão em si, não para seus fundamentos, associado à previsão, existente no art. 469, II, do Código de Processo Civil, de que os motivos, ainda que importantes para determinar o alcance da parte dispositiva da decisão, não fazem coisa julgada. Tem-se aqui uma confusão de institutos, talvez causada pelo arraigamento ao modelo da civil law sem abertura para os conceitos advindos do common law e de sua teoria dos precedentes. É que a porção vinculante da decisão, independentemente da previsão legal para tanto, é a ratio decidendi, que é a regra jurídica empregada pelo julgador para solucionar o caso anterior que se torna geral e abstrata e passa a ser aplicável também a outros casos futuros. As disposições legais que afirmam que os motivos da decisão não fazem coisa julgada não são infirmadas, porque o estabelecimento de precedentes não se confunde nem se relaciona diretamente com a coisa julgada, que permanece mesmo se dirigindo apenas ao dispositivo da decisão. ${ }^{118}$

\footnotetext{
${ }^{118}$ Samuel Meira Brasil Jr. analisa algumas ações diretas de inconstitucionalidade em que o STF assentou que "é inconstitucional a vinculação do reajuste de vencimentos de servidores estaduais ou municipais a índices federais de correção monetária". Em seguida, ele afirma que "as decisões do STF nos precedentes com efeito vinculante atingem todas as leis - estaduais ou municipais - que vinculam o reajuste dos servidores a índices federais, ainda que as leis não tenham sido objeto de julgamento pelo STF. Essa característica é, em verdade, a essência do efeito vinculante. Se se admitir o efeito vinculante apenas para a lei que foi objeto da ADI, então não há efeito vinculante, mas simplesmente res iudicata, já que a lei foi objeto da declaração de inconstitucionalidade. Para que haja efeito vinculante - como estabelecem a Lei 9.868/1999 e a EC 45/2004 - é imprescindível que se reconheça a eficácia vinculante da ratio decidendi para casos futuros ou pendentes" (Precedentes vinculantes e jurisprudência dominante na solução das controvérsias, p. 36-37). O autor está correto e esse argumento foi levantado pelo Ministro Gilmar Mendes nos dois casos acima resumidos. Apesar do acerto em tal posicionamento, o STF não o acolheu, pelas razões que se mostrou. E, ao recusar a aplicação da chamada "teoria dos motivos determinantes da decisão", o STF deixou de fazer incidir a ratio decidendi de seus precedentes mesmo nos casos para os quais a própria CRFB-1988 prevê expressamente a existência de efeito vinculante.
} 
De certo modo, o STF já aplica de maneira vinculada o entendimento que firmou em um caso para outros. Tal acontece, por exemplo, com as súmulas. Como visto, súmulas são enunciados que resumem o posicionamento do tribunal a respeito de uma dada matéria e a esse resumo se chega depois da compilação de qual foi o posicionamento da corte em alguns casos. Esquematicamente, o entendimento da corte em alguns casos é compilado na súmula por meio de enunciados e tais enunciados passam a ser usados como fundamento para julgar outros casos. Portanto, está-se usando para casos posteriores semelhantes os fundamentos dos casos anteriores que justificaram a edição da súmula, de maneira análoga ao que acontece com o modelo precedentalista. Não se está aqui a dizer que a súmula é um precedente, porque não é e sobre isso já se discorreu em outro lugar (item 2.3.1). O que se afirma é que esse apego apenas ao dispositivo da decisão não existe quando se usa a técnica de trabalho das súmulas, porque elas, na verdade, significam a transposição para casos futuros de entendimentos fixados em casos passados, independentemente de qualquer restrição da coisa julgada ao dispositivo.

Para ficar em um só exemplo, a Súmula Vinculante 32 foi proposta a partir do julgamento de um recurso extraordinário em relação a uma Lei do Estado de São Paulo no qual foi invocado como fundamento um julgado anterior do STF proferido em ação direta de inconstitucionalidade referente a uma lei do Estado do Rio de Janeiro. Ou seja, um julgado proferido em controle concentrado de constitucionalidade a respeito de uma lei do Estado do Rio de Janeiro serviu de argumento para uma decisão em controle difuso de constitucionalidade sobre uma Lei do Estado de São Paulo e deu origem a uma súmula vinculante que, como tal, passou a ser aplicada a todo e qualquer caso semelhante, independentemente da lei a que diga respeito. ${ }^{119}$ Não há rigorosamente nenhuma diferença entre este cenário e aquilo que os ministros que defendiam a aplicação da teoria dos motivos determinantes pretendiam fazer nos dois casos analisados acima. A única diferença é que aqui a aplicação do entendimento anterior do STF em controle concentrado de constitucionalidade ocorreu por meio de recurso extraordinário, enquanto a proposta daqueles ministros era para que isso acontecesse mais rápida e diretamente, por meio da

\footnotetext{
$\overline{{ }^{119} \text { A Súmula Vinculante } 32}$ tem a seguinte redação: “O ICMS não incide sobre alienação de salvados de sinistro pelas seguradoras". A proposta para sua edição surgiu ao final do julgamento do RE 588149/SP, Pleno, Rel. Min. Gilmar Mendes, maioria, j. em 16/2/2011, pub. DJE 6/6/2011. Nele se discutia a constitucionalidade da Lei Estadual 6.374/1989 de São Paulo e foi invocada como paradigma e fundamento a decisão proferida na MC na ADI 1332/RJ, Pleno, Rel. Min. Sydney Sanches, maioria, j. em 6/12/1995, pub. DJ 11/4/1997, p. 12178, a qual teve por objeto a Lei Estadual 1.423/1989 do Rio de Janeiro.
} 
reclamação constitucional.

Do que se pode ver da jurisprudência do Supremo Tribunal Federal até aqui observa-se existir um apego muito grande à necessidade de existência de uma norma constitucional prevendo expressamente que as demais autoridades judiciárias estão obrigadas/vinculadas a cumprir suas decisões, mesmo em controle concentrado de constitucionalidade e mesmo cabendo ao STF a guarda da Constituição (art. 102, caput, da Lei Magna de 1988). É assim quanto à interpretação restritiva do art. 102, $\S 2^{\circ}$, também da Carta Política de 1988, o qual prevê que "as decisões definitivas de mérito" terão efeito vinculante relativamente aos demais órgãos do Poder Judiciário, entendendo o STF que só a decisão é vinculante, não as razões que levaram até ela. De igual modo ocorre com o art. 103-A da Constituição da República de 1988. Apesar de o STF há décadas fazer uso de súmulas e de elas terem inequívoca e notória eficácia persuasiva, o tribunal nunca adotou uma postura mais "agressiva" relativamente a passar a considerá-las como obrigatórias independentemente de previsão constitucional. Foi preciso a Emenda Constitucional 45/2004 instituir a chamada súmula vinculante para que a súmula tivesse alguma eficácia obrigatória em relação aos demais órgãos do Poder Judiciário, e mesmo assim somente se aprovada por dois terços dos membros da corte. É muito pouco quando se poderia extrair a vinculação de qualquer precedente a partir apenas da constatação de que o sistema judiciário é hierarquizado em cortes superiores e inferiores e juízes de primeiro grau.

A obediência pelo julgador do caso posterior à decisão precedente não deveria precisar constar de um dispositivo constitucional expresso, como hoje ocorre somente em relação ao efeito vinculante das decisões proferidas em controle concentrado de constitucionalidade. O precedente deve ser seguido porque o Poder Judiciário funciona como um sistema, composto coletivamente por todas as suas instâncias, superiores e inferiores, as quais precisam funcionar com lógica e organicidade. Além disso, há as vantagens que o modelo de precedentes busca realizar (item 2.4). É algo, portanto, que deveria ser observado por pura e simples racionalidade, não por imposição legal e, menos ainda, constitucional. 


\subsection{Os precedentes no Brasil.}

O modelo brasileiro hoje, embora não seja assumidamente precedentalista, permite que se observe na casuística diária decisões que são proferidas acolhendo ou rejeitando uma dada tese ou pretensão apenas se reportando a várias ementas de acórdãos de tribunais, superiores ou não. Na prática, pode não haver muita diferença entre transcrever sucessivas ementas ou simplesmente se reportar a um precedente. Contudo, mesmo talvez não existindo muita diferença prática, um modelo assim caracterizado representa uma encampação de precedentes apenas parcial e, nessa qualidade, é um modelo imperfeito porque incompleto, uma vez que prescinde da observância de diversas outras práticas e técnicas que, somente quando realizadas em conjunto, garantem a harmonia e uma maior fluidez do sistema de julgamentos.

Por exemplo, os acórdãos cujas ementas são simplesmente transcritas como fundamento das decisões, mesmo quando egressos de cortes superiores, podem não ter sido proferidos com a preocupação prospectiva que necessariamente marca o sistema precedentalista, ou seja, podem ter sido produto de uma solução pensada apenas para o caso concreto anterior, sem nenhuma pretensão de se estender para casos seguintes ou até mesmo pretendendo ficar restrito ao caso concreto julgado originalmente.

Além disso, a própria necessidade existente nesse modelo incompleto de que, para que determinada tese seja aceita como prevalente é preciso se mostrar ela vem sendo reiteradamente acolhida em diversos casos - necessidade que se percebe pela praxe de se transcrever uma séria de ementas ou de exibir um grande número de julgados acolhendo a tese (conduta que é até imbrincada com a definição do que é jurisprudência) - afasta a própria noção ínsita ao modelo precedentalista de que a regra geral e abstrata é retirada de um único caso, o primeiro que realmente enfrenta a matéria, sem necessidade de que ela venha a ser (re)construída, mantida nem reafirmada caso após caso.

Contudo, e paradoxalmente, a partir da sucinta descrição feita acima se pode observar que apesar de integrar o sistema jurídico do civil law, o Brasil nunca deixou de se importar com a uniformidade de decisões nem com o contributo da jurisprudência para 
isso. Mostrou-se que o ordenamento processual tem sido alterado para receber institutos os mais variados, todos voltados a uniformizar decisões e a acelerar o julgamento de causas repetitivas por meio da valorização de decisões proferidas em momento anterior e cujo conteúdo deve ser observado.

Além disso, cuidou-se particularmente de três institutos (a súmula de caráter vinculante, a análise da existência ou não de repercussão geral nos recursos extraordinários apresentados ao STF e o processamento dos recursos especiais repetitivos dirigidos ao STJ) os quais não dependem da vontade do julgador de hierarquia inferior para serem cumpridos. O procedimento foi construído de um modo tal que, apesar de não se poder falar em efeito vinculante (exceto, claro, na súmula vinculante), em essência não há como não se cumprir as decisões proferidas pelo STF ou pelo STJ nessas matérias. Houve, por assim dizer, um "cerco" que impede qualquer fuga ao que foi decidido pelo STF e pelo STJ.

Relativamente às decisões em controle concentrado de constitucionalidade, para os quais a CRFB-1988 prevê expressamente efeitos vinculantes, o STF não quer exercê-lo em relação à ratio decidendi do julgado que realiza o controle de constitucionalidade, somente quanto ao seu dispositivo. Os argumentos usados na decisão, portanto, de muito pouco adiantam para casos futuros, exceto como argumentos de persuasão.

A conclusão a que se chega dessa análise é que o Brasil quer ter, mas ainda não tem, um modelo de precedentes. Está fazendo uma força legislativa enorme para prestigiar julgados passados. Criou engenhos procedimentais sofisticados para impedir as cortes inferiores de não observarem os entendimentos do STF e do SJT. Mas mesmo assim não se pode falar em precedente. Somente, no máximo, em jurisprudência. É que, apesar dos esforços que parecem ser sinceros, não existe aqui a aceitação de institutos como a ratio decidendi, regra geral, abstrata e vinculante que se desvincula do caso em que foi proferida para se aplicar a todos os casos seguintes semelhantes. E sem essa noção, os "precedentes", que a rigor não o são, ficam como se estivessem sendo impostos, e não cumpridos porque é o certo a se fazer. Nem mesmo no controle concentrado de constitucionalidade, para o qual é a própria Constituição quem prevê o efeito vinculante, esses conceitos estão bem 
delineados, e o STF deles se afasta. O legislador e, de certo modo, o constituinte, já entregou ao processo brasileiro bons institutos. É preciso apenas sejam os próprios profissionais da área a utilizá-los corretamente.

\subsection{Propostas de aprimoramento do modelo brasileiro.}

Para que um modelo verdadeiro e autêntico de precedentes tenha chance de vingar no Brasil, já que os passos dados até aqui, apesar de relevantes, foram insuficientes, é preciso primeiro a conscientização de que a corte que fixa o precedente tem deveres, principalmente o de proferir uma decisão bem construída, na qual todos os seus integrantes explorem coletivamente todos os argumentos objetivamente conhecidos a respeito do precedente que estão fixando, para dificultar a revisão logo em seguida do caso e também para impedir que alterações na composição tragam novos argumentos e mudem a decisão e para que se tenha como saber qual foi a ratio decidendi coletivamente fixada porque a mera soma de argumentos não fixa ratio decidendi e igualmente para que se saiba a maior ou menor extensão da ratio.

O estabelecimento de um precedente pode encerrar o caso concreto posto a julgamento e estabelecer bases para os casos futuros, mas não necessariamente cessa a controvérsia, as discussões, os debates a respeito do tema, daí ser recomendável que a corte só decida quando estiver de posse da maior quantidade de elementos fáticos e jurídicos possível - o que torna relevante o procedimento de elaboração da decisão (participação dos interessados, exposições de argumentos favoráveis e contrários a cada uma das teses etc.) para evitar que altere seu posicionamento, revendo o precedente, com frequência, o que gera insegurança jurídica.

O Brasil, talvez por estar em uma fase de transição/indecisão sobre que modelo quer seguir, se auto-amarrou. O ordenamento só prevê efeito vinculante expressa só para súmula e controle concentrado de constitucionalidade. Não há previsão de vinculação para as outras cortes. Existe uma necessidade de quórum qualificado para dar efeito prospectivo à decisão (modular efeitos). Todas essas medidas mostram um modelo de precedentes tolhido, preso a amarras que no modelo original não existem. A impressão que se tem é a 
de que os precedentes só podem ingressar onde a lei ou a Constituição autorizam.

No entanto, acaso se entenda que o emprego da técnica de precedentes (extração de regras jurídicas gerais, abstratas e vinculantes a partir de casos concretos) não se relaciona com o Poder Legislativo nem com a lei, sendo apenas uma técnica de solução de conflitos interna ao Poder Judiciário, ela pode surgir até espontaneamente ou estimulada pelos próprios tribunais, que tanto reclamam do volume de processos e ainda não exploraram suficientemente o que o modelo precedentalista pode oferecer a esse respeito.

Em consequência, a legislação deveria ser alterada para prever um aumento na possibilidade de decisões monocráticas, com previsão de recursos para o órgão colegiado mas com aplicação de sanções processuais e financeiras serveras para a parte sempre e de modo automático que a decisão monocrática proferida com base no precedente (e não com base em outra razão como intempestividade etc.) fosse mantida.

A imposição às partes e aos julgadores do dever processual de não apenas transcrever dezenas de ementas de acórdãos, mas de realizar um efetivo cotejo fático e da matéria de direito, isso tanto nas decisões quanto nas petições iniciais, à moda do que hoje só ocorre nos recursos por divergência jurisprudencial, para que a parte comprove que o precedente está em seu favor e para que a corte demonstre que o precedente existente foi surgido em situação semelhante.

Essas medidas otimizariam o modelo de precedentes no Brasil, permitindo o uso de suas vantagens, estando o processo brasileiro seguro de que isso não representaria um risco à evolução do direito quando necessária porque, como se buscou demonstrar, a distinção e superação asseguram a devida flexibilidade, exercida com responsabilidade e legitimidade. 
1. No que diz respeito à solução judicial de controvérsias, o stare decisis e o common law se funda em igualdade (incidência da mesma regra de direitos para casos assemelhados), previsibilidade (a repetição de soluções jurídicas as deixa previsíveis), economia (poupa-se tempo e recurso evitando decidir algo já decidido) e respeito (prestígio à solução dada pelos mais antigos).

2. Nos países do sistema romano-germânico (civil law) é notável o crescente aumento na importância dada aos precedentes, inclusive no Brasil.

3. Apesar disso, no Brasil ainda não existe consciência de que é preciso o respeito obrigatório aos precedentes porque as vantagens superam as desvantagens. Provavelmente será necessário que a lei diga que o precedente é vinculante e enquanto tal não ocorre o modelo precedentalista deixa de poder contribuir com a solução rápida dos litígios e de apresentar outras vantagens decorrentes de sua efetiva adoção.

4. Precedente, súmula e jurisprudência são institutos distintos, com características diferentes.

5. Há vários motivos para se seguir precedentes obrigatórios, dentre eles garantir isonomia processual, segurança jurídica (previsibilidade, uniformidade e estabilidade), celeridade (julgamentos mais facilitados por remissão ao precedente), racionalidade (desestimula a litigância daquele que já projeta a derrota), eficiência (sobra mais tempo para as causas inéditas), fortalecimento institucional e aumento da credibilidade do Judiciário, reforço do papel do STF como corte constitucional.

6. Os precedentes não violam o princípio constitucional da legalidade (art. $5^{\circ}$, II, 
da CRFB-1988). Em nenhum momento o Poder Judiciário deixar de realizar apenas suas funções típicas, como em qualquer caso, nem mesmo quando estabelece a regra geral, abstrata e vinculante do precedente.

7. O estabelecimento de um precedente tem um caráter prospectivo, de fixação de uma regra geral, abstrata e vinculante para o futuro. Isso pode levar a que a decisão tomada não seja a melhor nem a mais justa para o caso individualmente considerado, mas seja a melhor regra a ser fixada tendo em conta a regra geral de observância obrigatória nos casos futuros.

8. O precedente vincula as cortes de inferior hierarquia (eficácia vertical) e também a própria corte que o estabeleceu (eficácia horizontal), podendo esta revogar legitimamente o precedente se presentes os requisitos para tanto.

9. A ratio decidendi de um precedente é a parte de uma decisão que contém uma regra jurídica geral e abstrata mais ou menos ampla que deve obrigatoriamente ser observada nos julgados seguintes. Não se confunde com a fundamentação nem com o dispositivo da decisão, mas é apreendida a partir da análise deles em conjunto com os fatos e o pedido formulado.

10. Qualquer porção do julgamento da corte que não corresponda exatamente aos fundamentos usados para decidir o caso, é mero obiter dictum, sem nenhum tipo de vinculação.

11. O método abstrato-normativo é o melhor, ou o menos imperfeito, na detecção da ratio decidendi.

12. O stare decisis assumidamente busca reduzir o componente argumentativo, valorativo e ideológico relativamente àquilo que já foi decidido. Isso reduz a liberdade individual do julgador do caso seguinte, o qual vai precisar de muitos argumentos de fato e de direito acaso queira se afastar, alterar ou de alguma forma contornar o precedente. Mesmo assim, os elementos de ordem subjetiva não estão completamente afastados em um 
modelo precedentalista, já que a regra geral advinda do precedente, até por não ser enunciada textualmente como na lei, sempre permitirá alguma abertura para interpretações, valorações e influências.

13. Na distinção (distinguishing) primeiro se encontra a razão de decidir do precedente. Em seguida, os dois casos - o precedente e o atual - terão algumas de suas características comparadas e, a partir desse cotejo, será feita a conclusão sobre se os casos são realmente assemelhados, e por isso a razão de decidir do caso anterior deve ser repetida, ou se os casos são distintos, diferenciados, não sendo o caso de se aplicar a ratio decidendi do precedente.

14. A distinção e a não aplicação do precedente só se justifica se concretamente existir um pormenor ou uma particularidade que torne a regra geral contida no precedente inaplicável ao caso concreto e que, com alto grau de probabilidade, se tivesse sido considerado pelo tribunal que apreciou o precedente, teria levado a julgamento diversos.

15. A distinção é consistente isto é, feita corretamente, quando presente algum elemento diferenciador que, se estivesse presente na decisão que levou ao precedente, teria ensejado solução diversa. Será inconsistente a distinção feita sem a presença deste elemento. A distinção inconsistente ilegítima acontece quando se realiza a diferenciação do caso posterior em relação ao precedente invocando argumentos ou fatos que não explicam de modo plausível o porquê da diferença de tratamento entre eles. A distinção inconsistente legítima ocorre com uma finalidade evolutiva do direito, com vistas a forçar a rediscussão da regra contida no precedente para que se verifique novamente seu acerto ou se é mesmo a hora de mudar.

16. A distinção quando feita de modo legítimo representa uma forma de permitir flexibilidade e evolução ao direito e ao próprio modelo precedentalista, com a criação de regras novas e diversas para casos novos e diversos.

17. O órgão jurisdicional que realiza o distinguishing tem dois deveres processuais, assumir que está realizando uma distinção, demonstrando conhecer o 
precedente e seus fundamentos e razões, e explicar de modo particularmente fundamentado os motivos que levaram à distinção.

18. Existem técnicas de revogação do precedente que não violam os valores do modelo precedentalista.

19. Para a revogação de um precedente se exige que ele e a regra nele contida apresentem incongruência social ou inconsistência sistêmica. Esse será o motivo pelo qual a regra já não se mostra mais consentânea e pode vir a ser revogada. Além disso, é preciso que não exista violação à segurança jurídica ou, se houver, que essa violação seja compensada pelas vantagens decorrentes da revogação do precedente.

20. A prática recorrente de distinções inconsistentes legítimas ou a crítica doutrinária podem levar à revogação de um precedente.

21. Com vistas a garantir segurança jurídica, o tribunal pode modular os efeitos da revogação do precedente (revogação prospectiva total ou parcial).

22. Toda a evolução legislativa processual caminhou para aumentar a importância de julgados anteriores no deslinde das causas (aumento dos poderes do relator quando age com base em súmula ou jurisprudência dominante), restrições ao recebimento de recursos que contrariam súmula ou jurisprudência dominante, possibilidade de julgamento liminar de mérito de uma demanda com base apenas na jurisprudência do próprio juízo e, mais recentemente, o surgimento de instrumentos que, mesmo quando não são vinculantes, são cercado de instrumentos que na prática impedem seu descumprimento (súmula vinculante, repercussão geral e julgamento por amostragem dos recursos extraordinários e especiais repetitivos).

23. O STF nega eficácia vinculante à ratio decidendi das decisões que profere em controle concentrado de constitucionalidade, apesar da previsão de efeito vinculante prevista na Constituição. 
24. O Brasil precisa, espontaneamente ou por provocação das cortes que tanto reclamam do excesso de processos, adotar um verdadeiro modelo precedentalista, baseado não em jurisprudência ou em súmulas, mas em precedentes qualitativamente bem construídos, independentemente da quantidade.

25. A partir daí, outras medidas poderiam advir, como a obrigação da corte de explorar coletivamente todos os argumentos existentes a respeito do assunto, para que a ratio decidendi seja clara e duradoura; o incremento na atividade monocrática dos órgãos colegiados, com a previsão de multa para quem litigasse contra precedente regularmente estabelecido e explorado; a obrigação de as partes e os julgadores explorarem os fatos e fundamentos dos precedentes que invocam, para que se deixe claro sua pertinência. 
BIBLIOGRAFIA

ALENCAR, Rosmar Rodrigues. Efeito vinculante e concretização do direito. Porto Alegre: Sergio Antonio Fabris, 2009.

ALMEIDA, Fernando Dias Menezes de. Memória jurisprudencial: Ministro Victor Nunes. Brasília: Supremo Tribunal Federal, 2006.

ALVES, Francisco Glauber Pessoa. O princípio jurídico da igualdade e o processo civil brasileiro. Rio de Janeiro: Forense, 2003.

AMORIM, Aderbal Torres de. O novo recurso extraordinário. Porto Alegre: Livraria do Advogado, 2010.

ANCEL, Marc. Utilidade e métodos do direito comparado. Porto Alegre: Sergio Antonio Fabris, 1980.

ANDRADE, Fábio Martins de. Modulação em matéria tributária - o argumento pragmático ou consequencialista de cunho econômico e as decisões do STF. São Paulo: Quartier Latin, 2011.

ANDREWS, Neil. A Suprema Corte do Reino Unido: reflexões sobre o papel da mais alta Corte Britânica. Revista de Processo. São Paulo. n. 186. p. 299-312. ago. 2010.

. O moderno processo civil - formas judiciais e alternativas de resolução de conflitos na Inglaterra. São Paulo: Revista dos Tribunais, 2009.

ANDRIGHI, Fátima Nancy. Recursos repetitivos. Revista de Processo. São Paulo. n. 185. p. 265-281. julho. 2010.

APPIO, Eduardo. Controle difuso de constitucionalidade. Curitiba: Juruá, 2009.

ARMELIN, Donaldo. Ação civil pública. Legitimidade processual e legitimidade política. In: SALLES, Carlos Alberto de (org.). Processo civil e interesse público - o processo como instrumento de defesa social. São Paulo: Revista dos Tribunais, 2003, p. 113-124.

ASSIS, Araken de. Manual dos recursos. 2 ed. São Paulo: Revista dos Tribunais, 2008.

ÁVILA, Humberto. Teoria da igualdade tributária. 2 ed. São Paulo: Malheiros, 2009. . Teoria dos princípios. 11 ed. São Paulo: Malheiros, 2010.

AZEM, Guilherme Beux Nassif. Repercussão geral da questão constitucional no recurso 
extraordinário. Porto Alegre: Livraria do Advogado, 2009.

BARIONI, Rodrigo. Ação rescisória e recursos para os tribunais superiores. São Paulo: Revista dos Tribunais, 2010.

BRAGHITTONI, R. Ives. Recurso extraordinário - uma análise do acesso ao Supremo Tribunal Federal. São Paulo: Atlas, 2007.

BRASIL JR., Samuel Meira. Precedentes vinculantes e jurisprudência dominante na solução das controvérsias. Tese (Doutorado em Direito). Faculdade de Direito. Universidade de São Paulo. 2010. 351p.

BRASIL JUNIOR, Samuel Meira. Precedentes vinculantes e jurisprudência dominante na solução das controvérsias. Tese (doutorado em Direito). Faculdade de Direito. Universidade de São Paulo. São Paulo, 2010. 351 f.

BRENNER, Saul; e SPAETH, Harold J. Stare indecisis - the alteration of precedent on the Supreme Court, 1946-1992. New York: Cambridge University Press, 1995.

CABRAL, Antonio do Passo. Os efeitos processuais da audiência pública. Revista de Direito do Estado. Rio de Janeiro. n. 1. p. 199-213. abr/jun 2006.

CAMBI, Eduardo. Neoconstitucionalismo e neoprocessualismo - direitos fundamentais, políticas públicas e protagonismo judiciário. São Paulo: Revista dos Tribunais, 2009.

CAMPANELLI, Luciana Amicucci. Poderes instrutórios do juiz e a isonomia processual. São Paulo: Juarez de Oliveira, 2006.

CAPPELLETTI, Mauro. Juizes legisladores?. Porto Alegre: Sergio Antonio Fabris, 1999. . Processo, ideologias e sociedade. v. 1. Porto Alegre: Sergio Antonio Fabris, 2008. 2010 . . Processo, ideologias e sociedade. v. 2. Porto Alegre: Sergio Antonio Fabris,

CARPENA, Márcio Louzada. Os poderes do juiz no common law. Revista de Processo. São Paulo. n. 185. p. 180-220. fev. 2010.

CARRILHO, Cristiano. Manual de história dos sistemas jurídicos. Rio de Janeiro: Elsevier, 2009.

CARVAlHO, Fabiano. Poderes do relator nos recursos - art. 557 do CPC. São Paulo: Saraiva, 2008.

CINTRA, Antônio Carlos de Araújo; GRINOVER, Ada Pellegrini e DINAMARCO, Cândido Rangel. Teoria geral do processo. 21 ed., São Paulo: Malheiros, 2005. 
COLE, Charles D. Stare Decisis na Cultura Jurídica dos Estados Unidos. O Sistema de Precedente Vinculante do Common Law. Revista dos Tribunais. São Paulo, v. 87, n. 752, p. 12, jun. 1998.

CÔRTES, Osmar Mendes Paixão. Súmula vinculante e segurança jurídica. São Paulo: Revista dos Tribunais, 2008.

CUNHA, Leonardo Carneiro da. Anotações sobre o incidente de resolução de demandas repetitivas previsto no projeto do novo Código de Processo Civil. Revista de Processo. São Paulo. n. 193. p. 255-279. mar. 2011.

. O regime processual das causas repetitivas. Revista de Processo. São Paulo. n. 179. p. 139-174. jan. 2010.

DANTAS, Bruno. Repercussão geral. São Paulo: Revista dos Tribunais, 2008.

DAVID, René. O direito inglês. 2 ed. São Paulo: WMF Martins Fontes, 2006.

Fontes, 2002.

Os grandes sistemas do direito contemporâneo. 4 ed. São Paulo: Martins

DERZI, Mizabel Abreu Machado. Modificações da jurisprudência no Direito Tributário proteção da confiança, boa-fé objetiva e irretroatividade como limitações constitucionais ao poder judicial de tributar. São Paulo: Noeses, 2009.

DINAMARCO, Cândido Rangel. Súmulas vinculantes. In: processo civil moderno. São Paulo: Malheiros, 2010, p. 213-244. . Fundamentos do

DUXBURY, Neil. The nature and authority of precedent. Cambridge: Cambridge University Press, 1988.

DWORKIN, Ronald. Levando os direitos a sério. São Paulo: Martins Fontes, 2002. . O império do direito. São Paulo: Martins Fontes, 2007.

EISENBERG, Melvin Aron. The nature of the common law. Cambridge: Harvard University Press, 1988.

FARNSWORTH, Edgard Allan. Introdução ao sistema jurídico dos Estados Unidos. Rio de Janeiro: Forense, 1963.

FERNANDO, Emmanuel Q. The role and logic of substantive reasons adjudication. Philippine Law Journal, v. 66, p. 56-89, 1991.

FERRAZ JR., Tércio Sampaio; CARRAZZA, Roque Antonio; e NERY JUNIOR, Nelson. Efeitos ex nunc e as decisões do STJ. São Paulo: Manole, 2008.

FRANÇOLIN, Wanessa de Cássia. A ampliação dos poderes do relator nos recursos cíveis. 
Rio de Janeiro: Forense, 2006.

GARAPON, Antoine; e PAPAPOULOS, Ioannis. Juger em Amérique et em France culture juridique française et common law. Paris: Odile Jacob, 2003.

Julgar nos Estados Unidos e na França - cultura jurídica francesa e common law em uma perspectiva comparada. Rio de Janeiro: Lumen Juris, 2008.

GERHARDT, Michel J. The power of precedent. Oxford: Oxford University Press, 2001.

GOMES, Mariângela Gama de Magalhães. Direito penal e interpretação jurisprudencial do princípio da legalidade às súmulas vinculantes. São Paulo: Atlas, 2008.

GOODHART, Arthur Lehman. Determining the ratio decidendi of a case. Yale Law Journal. New Haven, v. XL, n. 2, p. 161-183, dez. 1930.

p. 117-124, mar. 1959.

GRINOVER, Ada Pellegrini. O tratamento dos processos repetitivos. In: JAYME, Fernando Gonzaga; e FARIA, Juliana Cordeiro de (coords.). Processo civil - novas tendências - homenagem ao professor Humberto Theodoro Jr. Belo Horizonte: Del Rey, 2008.

GROSS, Marco Eugênio. A posterior declaração de (in) constitucionalidade contrária ao conteúdo de decisões já passadas em julgado em matéria tributária: um conflito entre a segurança jurídica e a supremacia da Constituição. Revista de Processo. São Paulo. n. 185. p. 151-174. julho. 2010.

HALL, Kermit L.; e ELY JR., James W. The Oxford guide to Unites States Supreme Court decisions. 2 ed. Oxford: Oxford, 2009.

HANSFORD, Thomas G.; e SPRIGGS II, James F. The politics of precedent on the U.S. Supreme Court. Princeton: Princeton University Press, 2006.

JORGE, Flávio Cheim. Embargos de divergência: alguns aspectos estruturantes. Revista de Processo. São Paulo. n. 190. p. 9-36. dez. 2010.

KNIJNIK, Danilo. O recurso especial e a revisão da questão de fato pelo Superior Tribunal de Justiça. Rio de Janeiro: Forense, 2005.

LASPRO, Oreste Nestor de Souza. O objeto dos embargos de divergência. Revista de Processo. São Paulo. n. 186. p. 9-30. ago. 2010.

LEITE, Glauco Salomão. Súmula vinculante e jurisdição constitucional brasileira. Rio de Janeiro: Forense, 2007.

LEONEL, Ricardo de Barros. Reclamação constitucional. São Paulo: Revista dos 
Tribunais, 2011.

LIMA, Augusto César Moreira. Precedentes no direito. São Paulo: LTr, 2001.

LIMA, Martonio Mont'Alverne Barreto. Súmula vinculante e Constituição dirigente: uma questão da soberania. In: OLIVEIRA NETO, Francisco José Rodrigues de; COUTINHO, Jacinto Nelson de Miranda; MEZZAROBA, Orides; e BRANDÃO, Paulo de Tarso (organizadores). Constituição e Estado Social - os obstáculos à concretização da Constituição. São Paulo: Revista dos Tribunais, 2008, p. 275-286.

LOBO, Arthur Mendes. Reflexões sobre o incidente de resolução de demandas repetitivas. Revista de Processo. São Paulo. n. 185. p. 233-244. julho. 2010.

LOPES, João Batista. Tutela antecipada no processo civil brasileiro. 4 ed. São Paulo: Revista dos Tribunais, 2009.

LOPES, José Reinaldo de Lima. Modelos históricos do Judiciário: poder político ou poder neutro?. In: . Direitos sociais - teoria e prática. São Paulo: Método, 2006, p. $15-32$.

LOR, Encarnacion Alfonso. Súmula vinculante e repercussão geral - novos institutos de direito processual constitucional. São Paulo: Revista dos Tribunais, 2009.

LOSANO, Mario G. Os grandes sistemas jurídicos. São Paulo: Martins Fontes, 2007.

MACCORMICK, Neil. Argumentação jurídica e teoria do direito. São Paulo: Martins Fontes, 2006.

. Retórica e o Estado de direito. Rio de Janeiro: Elsevier, 2008.

MANCUSO, Rodolfo de Camargo. Acesso à justiça - condicionantes legítimas e ilegítimas. São Paulo: Revista dos Tribunais, 2011.

. A realidade brasileira e os tribunais da federação - STF e STJ: inevitabilidade de elementos de contenção dos recursos a ele dirigidos. In: Processo e Constituição: estudos em homenagem ao Professor José Carlos Barbosa Moreira. São Paulo: Revista dos Tribunais, 2006.

- A resolução dos conflitos e a função judicial no contemporâneo Estado de Direito. São Paulo: Revista dos Tribunais, 2009.

dos Tribunais, 2007.

. Divergência jurisprudencial e súmula vinculante. 3 ed. São Paulo: Revista . Jurisdição coletiva e coisa julgada - teoria geral das ações coletivas. São Paulo: Revista dos Tribunais, 2006.

Recurso extraordinário e recurso especial. 9 ed. São Paulo: Revista dos 
Tribunais, 2006.

MARCATO, Antonio Carlos. Crise da justiça e influência dos precedentes judiciais no direito processual civil brasileiro. Tese (concurso para professor titular). Faculdade de Direito. Universidade de São Paulo. São Paulo, 2008. 265 p.

MARINONI, Luiz Guilherme; e MITIDIERO, Luiz Guilherme. O projeto do CPC críticas e propostas. São Paulo: Revista dos Tribunais, 2010.

Tribunais, 2007.

Repercussão geral no recurso extraordinário. São Paulo: Revista dos

MARINONI, Luiz Guilherme. Aproximação crítica entre as jurisdições de civil law e de common law e a necessidade de respeito aos precedentes no Brasil. Revista de Processo. São Paulo. n. 172. p. 175-232. jun. 2009.

. Eficácia vinculante: a ênfase à ratio decidendi e à força obrigatória dos precedentes. Revista de Processo. São Paulo. n. 184. p. 9-41. junho. 2010.

. Precedentes obrigatórios. São Paulo: Revista dos Tribunais, 2010.

. Técnica processual e tutela dos direitos. São Paulo: Revista dos Tribunais,

2004.

MARTINS, Sandro Gilbert. Súmula vinculante. Revista de Processo. São Paulo. n. 172. p. 313-324. jun. 2009.

MATTOS, Luiz Norton Baptista de. "Súmula" vinculante: análise das principais questões jurídicas no contexto da reforma do Poder Judiciário e do processo civil brasileiro. Rio de Janeiro: Lumen Juris, 2010.

MAUÉS, Antonio Moreira. Ensaio sobre a harmonização da jurisprudência constitucional. In: OLIVEIRA NETO, Francisco José Rodrigues de; COUTINHO, Jacinto Nelson de Miranda; MEZZAROBA, Orides; e BRANDÃO, Paulo de Tarso (organizadores). Constituição e Estado Social - os obstáculos à concretização da Constituição. São Paulo: Revista dos Tribunais, 2008, p. 83-97.

MELlo, Patrícia Perrone Campos. Precedentes - o desenvolvimento judicial do direito no constitucionalismo contemporâneo. Rio de Janeiro: Renovar, 2008.

MENDES, Leonardo Castanho. O recurso especial $e$ o controle difuso de constitucionalidade. São Paulo: Revista dos Tribunais, 2006.

MERRYMAN, John Henry; e PÉREZ-PERDOMO, Rogelio. A tradição da civil law - uma introdução aos sistemas jurídicos da Europa e da América Latina. Porto Alegre: Sergio Antonio Fabris, 2009.

MITIDIERO, Daniel. A multifuncionalidade do direito fundamental ao contraditório e a 
improcedência liminar (art. 285-A, CPC): resposta à crítica de José Tesheiner. Revista de Processo. São Paulo. n. 144. p. 105-111. fev. 2007.

MORATO, Leonardo L. Reclamação e sua aplicação para o respeito da súmula vinculante. São Paulo: Revista dos Tribunais, 2007.

MOREIRA, José Carlos Barbosa. Algumas inovações da Lei n. 9.756 em matéria de recursos civis. In: Saraiva, 2001, p. 71-86. . Temas de direito processual (sétima série). São Paulo:

- Súmula, jurisprudência, precedente: uma escalada e seus riscos. In: 313. . Temas de direito processual (nona série). São Paulo: Saraiva, 2007, p. 299-

NERY JUNIOR, Nelson; e Nery, Rosa Maria de Andrade. Código de Processo Civil comentado. 11 ed. São Paulo: Revista dos Tribunais, 2010.

dos Tribunais, 2010.

. Princípios do processo na Constituição Federal. 10 ed. São Paulo: Revista

NOGUEIRA, Gustavo Santana. Stare decisis et non quieta movere: a vinculação aos precedentes no direito comparado e brasileiro. Rio de Janeiro: Lumen Juris, 2011.

NUNES, Jorge Amaury Maia. Segurança jurídica e súmula vinculante. São Paulo: Saraiva, 2010 .

PARENTE, Eduardo de Albuquerque. Jurisprudência - da divergência à uniformização. São Paulo: Atlas, 2006.

PEREIRA, Celso de Tarso. "Common Law e "Case Law". Revista dos Tribunais. São Paulo, v. 77, n. 638, p. 69-74, dez. 1988.

PICARDI, Nicola. Jurisdição e processo. Rio de Janeiro: Forense, 2008.

PINTO, Luis Filipe Marques Porto Sá. Técnicas de tratamento macromolecular dos litígios - tendência da coletivização da tutela processual civil. Revista de Processo. São Paulo. n. 185. p. 117-144. julho. 2010.

PORTANOVA, Rui. Princípios do processo civil. Porto Alegre: Livraria do Advogado, 1995.

PORTELLA, Glória Maria Guimarães de Pádua Ribeiro. Teoria crítica do recurso especial. Rio de Janeiro: Lumen Juris, 2004.

RAMIRES, Maurício. Crítica à aplicação de precedentes no direito brasileiro. Porto Alegre: Livraria do Advogado, 2010.

RE, Edward D. "Stare decisis”. Revista de Processo. São Paulo. n. 73. p. 47-54. jan./mar. 
1994.

REICHELT, Luis Alberto. A duração razoável do processo, o julgamento do recurso extraordinário dotado de repercussão geral e a modulação dos efeitos da declaração de inconstitucionalidade. Revista de Processo. São Paulo. n. 193. p. 131-149. mar. 2011.

ROCHA, José de Albuquerque. Súmula vinculante e democracia. São Paulo: Atlas, 2009.

RODRIGUES, Ruy Zoch. Ações repetitivas - casos de antecipação de tutela sem o requisito de urgência. São Paulo: Revista dos Tribunais: 2010.

ROSA, Alexandre Morais da. Crítica à hermenêutica do conforto: a súmula (vinculante) como se imagem fosse. In: OLIVEIRA NETO, Francisco José Rodrigues de; COUTINHO, Jacinto Nelson de Miranda; MEZZAROBA, Orides; e BRANDÃO, Paulo de Tarso (organizadores). Constituição e Estado Social - os obstáculos à concretização da Constituição. São Paulo: Revista dos Tribunais, 2008, p. 29-40.

ROSSI, Júlio César. $O$ precedente à brasileira: súmula vinculante e o incidente de resolução de demandas repetitivas. Revista de Processo. São Paulo. n. 208. p. 131-149. jun. 2012.

RUMBLE JR., Wilfrid E. American legal realism - Skepticism, reform and the judicial process. Ithaca: Cornell University Press, 1968.

SÁ, Djanira Maria Radamés de. Súmula vinculante - análise crítica de sua adoção. Belo Horizonte: Del Rey, 1996.

SACCO, Rodolfo. Introdução ao direito comparado. São Paulo: Revista dos Tribunais, 2001.

SANCHES, Sidney. Uniformização da jurisprudência. São Paulo: Revista dos Tribunais, 1975.

SANTO, Bruno Vianna Espírito. Análise constitucional do julgamento liminar de improcedência. Revista de Processo. São Paulo. n. 187. p. 141-159. mar. 2010.

SANTOS, Evaristo Aragão. Sobre a importância e os riscos que corre hoje a criatividade jurisprudencial. Revista de Processo. São Paulo. n. 181. p. 38-48. mar. 2010.

SCHAUER, Frederick. Precedent. Em: <http://ssrn.com/abstract=1836384>. Acesso em: 23 dezembro 2012.

SCHÜTZ, Vanessa Casarin. O princípio da isonomia e o conflito entre sentenças coletivas e individuais. Porto Alegre: Livraria do Advogado, 2009.

SERAU JÚNIOR, Marco Aurélio; e REIS, Silas Mendes dos. Recursos especiais repetitivos no STJ. São Paulo: Método, 2009. 
SÈROUSSI, Roland. Introdução ao direito inglês e norte-americano. São Paulo: Landy, 2001.

SERVIDIO-DELABRE, Eileen. Common law - introduction to the English and American legal systems. Paris, Dalloz, 2004.

SGARBOSSA, Luís Fernando; e JENSEN, Geziela. Elementos de direito comparado ciência, política legislativa, integração e prática judiciária. Porto Alegre: Sergio Antonio Fabris, 2008.

SHAPIRO, Martin. Toward a theory of stare decisis. The Journal of Legal Studies, p. 125134, 1972.

SIFUENTES, Mônica. Súmula vinculante - um estudo sobre o poder normativo dos tribunais. São Paulo: Saraiva, 2005.

SILTALA, Raimo. A theory of precedent - from analytical positivism to a post-analytical philosophy of law. Portland: Hart, 2000.

SILVA, Celso de Albuquerque. Do efeito vinculante - sua legitimidade e aplicação. Rio de Janeiro: Lumen Juris, 2005.

SILVA, Ticiano Alves e. Intervenção de sobrestado no julgamento por amostragem. Revista de Processo. São Paulo. n. 182. p. 234-257. abril. 2010.

SOARES, Guido Fernando Silva. common law - introdução ao direito dos EUA. 2 ed. São Paulo: Revista dos Tribunais, 2000.

SORMANI, Alexandre; e SANTANDER, Nelson Luis. Súmula vinculante - um estudo à luz da Emenda Constitucional 45, de 08.12.2004. 2 ed. Curitiba: Juruá, 2008.

SOUTO, João Carlos. Suprema corte dos Estados Unidos - principais decisões. Lumen Juris, 2008.

SOUZA, Marcelo Alves Dias de. Do precedente judicial à súmula vinculante. Curitiba: Juruá, 2006.

SOUZA, Roberto Carvalho de. Recurso especial. Rio de Janeiro: Forense, 1995.

SPAETH, Harold J.; e SEGAL, Jeffrey A. Majority rule or minority will - Adherence to precedent on the U.S. Supreme Court. Cambridge: Cambridge University Press, 2001.

STONE, Julius. The ratio of the ratio decidendi. The Modern Law Review. London, v. 22, n. 6 , p. 598-620, nov. 1959 .

STRECK, Lenio Luiz. Súmulas no direito brasileiro - eficácia, poder e função - a ilegitimidade constitucional do efeito vinculante. Porto Alegre: Livraria do Advogado, 1998. 
SUMMERS, Robert S. Precedent in the United States (New York State). In: MACCORMICK, D. Neil; SUMMERS, Robert S.; e GOODHART, Arthur L. Interpreting precedents. Surrey: Ashgate, 1997, p. 355-405.

SUNSTEIN, Cass R. One case at a time - judicial minimalism on the Supreme Court. Cambridge: Harvard University Press, 2001.

TALAMINI, Eduardo. Novos aspectos da jurisdição constitucional brasileira: repercussão geral, força vinculante, modulação dos efeitos do controle de constitucionalidade e alargamento do objeto do controle direto. Tese (livre-docência em Direito). Faculdade de Direito. Universidade de São Paulo. São Paulo, 2008. 332 p.

TARANTO, Caio Márcio Gutteres. Precedente judicial - autoridade e aplicação na jurisdição constitucional. Rio de Janeiro: Forense, 2010.

TARUFFO, Michele. Icebergs do common law e civil law? Macrocomparação $e$ microcomparação processual e o problema da verificação da verdade. Revista de Processo. São Paulo. n. 181. p. 167-172. mar. 2010.

TAVARES, André Ramos. Nova lei da súmula vinculante - estudos e comentários à Lei 11.417, de 19.12.2006. 2 ed. São Paulo: Método, 2007.

TEBET, Diogo. Súmula vinculante em matéria criminal. São Paulo: IBCCRIM, 2010.

TEIXEIRA, Odelmir Bilhalva. Súmula vinculante: perigo ou solução. Campinas: Russel, 2008.

TEIXEIRA, Rodrigo Valente Giublin. Recursos especiais repetitivos. Revista de Processo. São Paulo. n. 189. p. 161-186. nov. 2010.

THEODORO JÚNIOR, Humberto; NUNES, Dierle; e BAHIA, Alexandre. Breves considerações sobre a politização do Judiciário e sobre o panorama de aplicação no direito brasileiro - análise da convergência entre o civil law e o common law e os problemas da padronização decisória. Revista de Processo. São Paulo. n. 189. p. 9-52. nov. 2010.

TIMM, Luciano Benetti; e TRINDADE, Manoel Gustavo Neubarth. As recentes alterações legislativas sobre os recursos aos tribunais superiores: a repercussão geral e os processos repetitivos sob a ótica da law and economics. Revista de Processo. São Paulo. n. 178. p. 153-179. dez. 2009.

TOCQUEVILle, Alexis de. A democracia na América - leis e costumes. Livro 1. 2 ed. São Paulo: Martins Fontes, 2005.

TORREÃO, Marcelo Pires. Dos embargos de divergência - teoria e prática no Superior Tribunal de Justiça e no Supremo Tribunal Federal. Porto Alegre: Sergio Antonio Fabris, 2004. 
TORRES, Heleno Taveira. Direito Constitucional Tributário e segurança jurídica metódica da segurança jurídica do sistema constitucional tributário. São Paulo: Revista dos Tribunais, 2011.

TRIBE, Laurence; e DORF, Michael. Hermenêutica constitucional. Belo Horizonte: Del Rey, 2007.

VALIM, Rafael. O princípio da segurança jurídica no direito administrativo brasileiro. Malheiros, 2010.

VIANA, Ulisses Schwarz. Repercussão geral sob a ótima da teoria dos sistemas de Niklas Luhmann. São Paulo: Saraiva, 2010.

VIEIRA, Andréia Costa. Civil law e common law - os dois grandes sistemas legais comparados. Porto Alegre: Sergio Antonio Fabris, 2007.

VIGLIAR, José Marcelo Menezes. Uniformização de jurisprudência - segurança jurídica e dever de uniformizar. São Paulo: Atlas, 2003.

VILE, John R. Essential Supreme Court decisions - summaries of leading cases in U.S. Constitutional Law. 15 ed. Lanham: Rowman \& Littlefield, 2010.

WAMBIER, Teresa Arruda Alvim; e MEDEIROS, Maria Lúcia Lins Conceição de. Recursos repetitivos - realização integral da finalidade do novo sistema impõe mais do que a paralisação dos recursos especiais que estão no $2^{\circ}$ grau. Revista de Processo. São Paulo. n. 191. p. 187-197. jan. 2011.

WAMBIER, Teresa Arruda Alvim. Controle das decisões judiciais por meios de recurso de direito estrito e de ação rescisória. São Paulo: Revista dos Tribunais, 2001.

. Estabilidade e adaptabilidade como objetivos do direito: civil law e common law. Revista de Processo. São Paulo. n. 172. p. 121-174. jun. 2009.

. Recurso especial, recurso extraordinário e ação rescisória. 2 ed. São Paulo: Revista dos Tribunais, 2008.

Recursos como uma forma de fazer "render" o processo no Projeto 166/2010. Revista de Processo. São Paulo. n. 189. p. 275-283. nov. 2010.

ZANETI JÚNIOR, Hermes. Processo constitucional - o modelo constitucional do processo civil brasileiro. Rio de Janeiro: Lumen Juris, 2007. 